

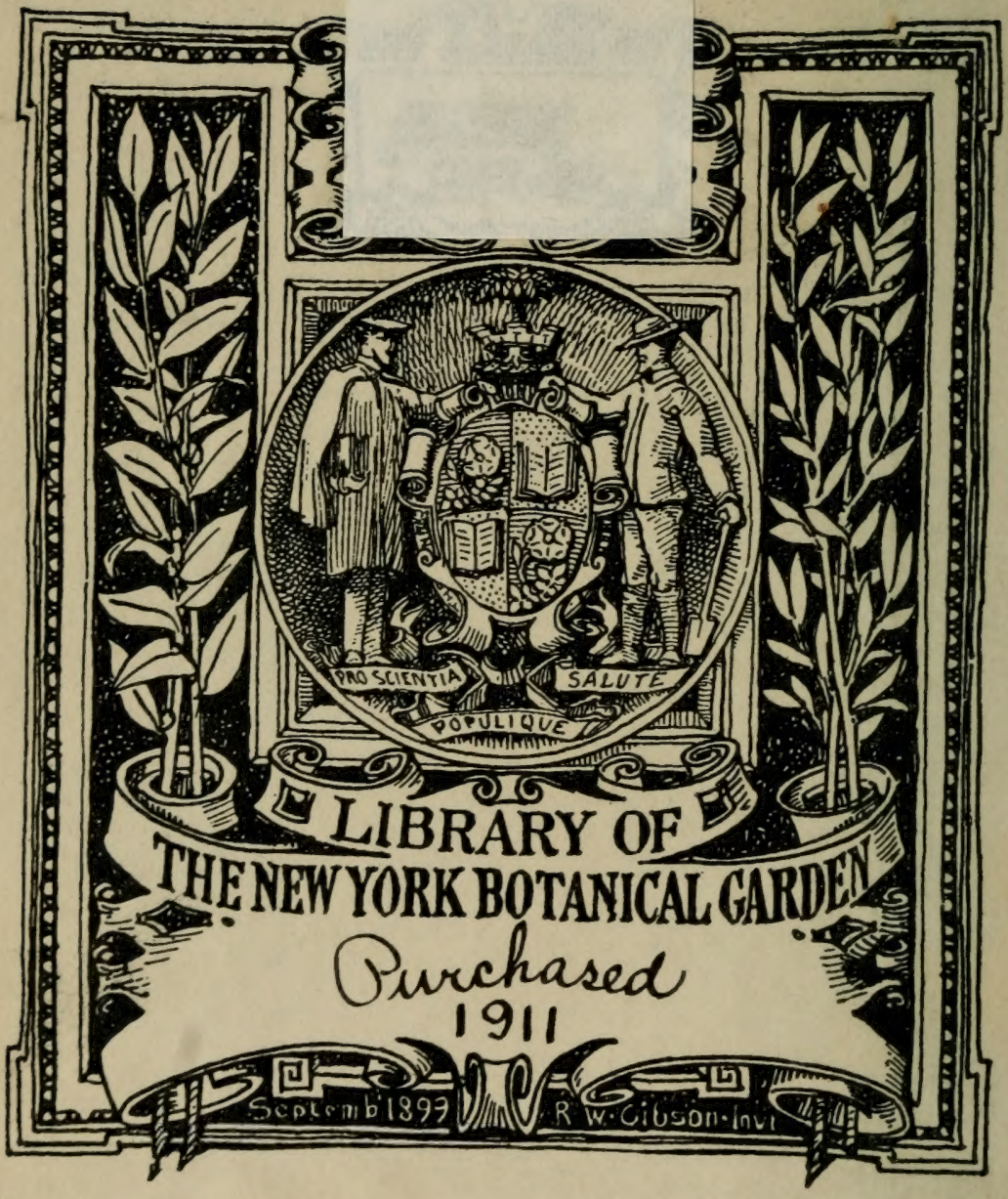


a.w 3 -

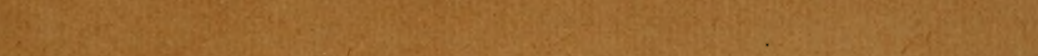
Whes W.

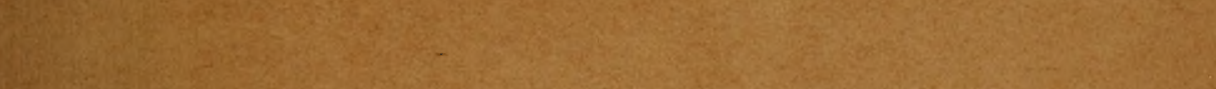

\section{(5)}

(2)

disting:

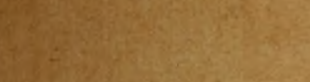

4.5:

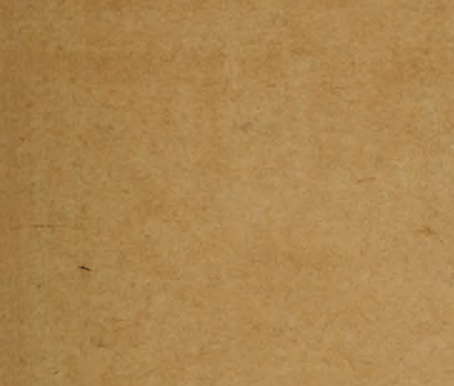

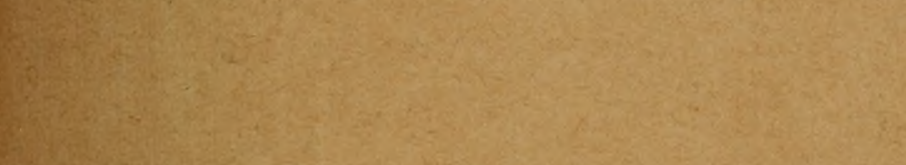

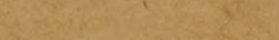

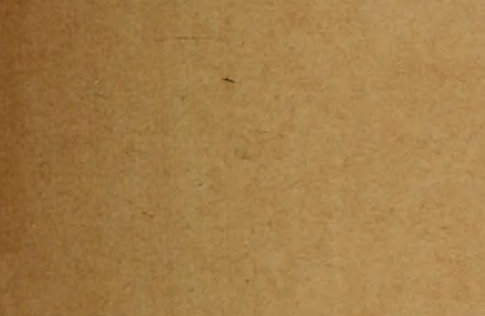



NATURE STUDIES 




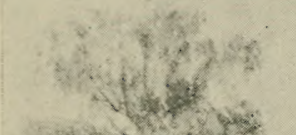

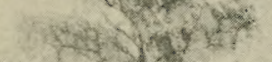

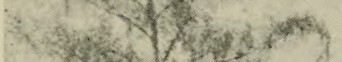

3

ind notion.

Notis.

2. Notitis 3. 1 mint

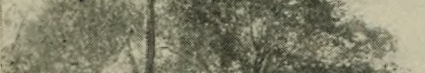

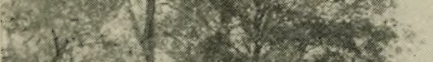

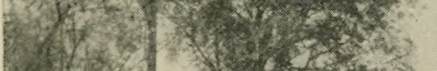

3.1.

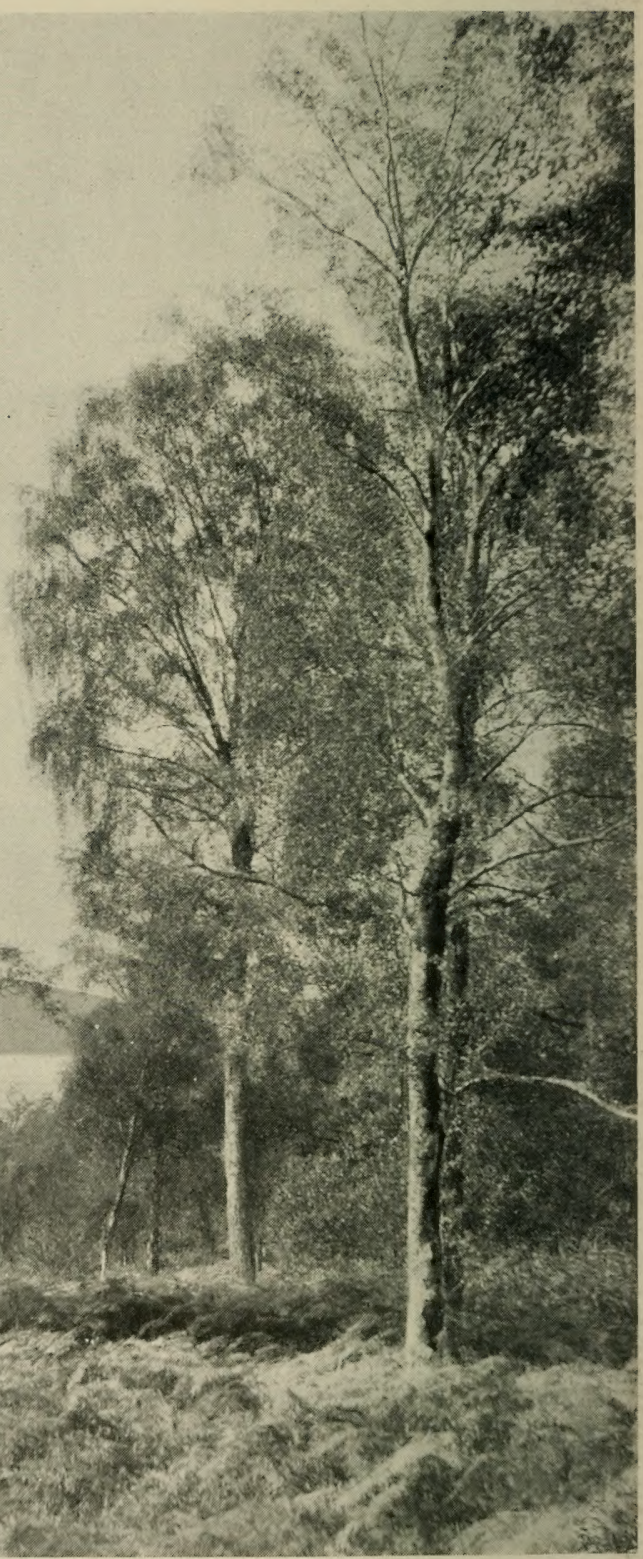

B 7

BIRCH AND BRACKEN 


\title{
NATURE STUDIES (PLANT LIFE)
}

\author{
BY \\ G. F. SCOTT ELLIOT \\ M.A. Cantab., B.Sc. Edin., F.L.S., F.R.G.S. \\ I.ECTURER ON BOTANY, GLASGOW AND WEST OF SCOTLAND TECHNICAL COLLEGE \\ AUTHOR OF "A NATURALIST IN MID AFRICA" \\ "FLORA OF DUMFRIESSHIRE," ETC.
}

\section{LIBRARY \\ NEW YORK \\ BOT ANICAL \\ GARDEN.}

\author{
LONDON \\ BLACKIE \& SON, Limited, 50 OLD BAILEY, E.C. \\ GLASGOW AND DUBLIN \\ I 903
}


.E4 


\section{PREFACE}

oxyplativ

THIS book has been written with the view of helping those non-professional lovers of "Nature Study" who are really interested in the mystery of Plant-life.

During the first few years of my experience as a teacher in Glasgow, I followed, in my. lectures, the ordinary botanical lines; but in course of time it became evident that, for many of my students, these formal lines were not at all suitable. I have, therefore, of late years, endeavoured, in all popular classes, to follow a different plan, and, as far as possible, to do without technical terms.

After all, few students have the intention of becoming professors of botany; though they may all be promising naturalists, and quite capable of doing very valuable service to science, when they have once conquered the initial difficulties. I have been much encouraged in my attempt by discovering that in Germany there is a decided tendency towards the disuse of all but necessary technical terms. In England, the terminology of Botany is fast becoming a sort of Chinese alphabet, which will require so much time to master, that nothing of a lifetime will be left in which to use it in the study of Nature.

All students of plant-life, and especially those engaged as teachers in our elementary or higher schools, whose time is exceedingly limited, are appalled at botanical language. Too often they obtain the 
impression, that the mere description of a plant, or part of a plant, in scientific terms, constitutes the end, instead of the very beginning of the Science of Botany.

That I have been obliged to say chloroplyyll instead of "leaf green," or cambizm instead of "building ring," is not my fault. These terms have been fastened on the English language, and it would be hypercritical to displace them. I have gone as far as I dared, not as far as I would like, in the direction of suppression.

Every detail in the structure of a plant has both a history and a meaning. My aim has been to point out how the student of Nature can follow part of the history, and can discover the meaning. This is not very difficult, provided that the right method is followed, which is, to begin with the plant, and then to use the books. It has not been part of my scheme to bring my own work prominently forward. I have been thankful to utilise everything which I could find (see bibliography) that seemed in any way to the point. More especially, the valuable works of Lord Avebury, Kerner Von Marilaun's Natural History of Plants, and IVarming's and Ludwig's Handbooks, have been found indispensable.

It is impossible to mention here all those whose observations have been found useful, and to whom therefore my thanks are due. The references will be found in the bibliography arranged in such a way that they can be checked in the book itself. Many statements and explanations in the text, which appear to contradict well-known British authorities, depend on German or other authors, whose works are not so well known in Britain.

Nevertheless, I must run the risk of criticism with regard to a considerable proportion of the book, which 
is, so far as I know, based on my own observations and is not to be found in any previously published work, at least to my knowledge.

I have consciously used working hypotheses very freely, because they so often afford a ready method of understanding a whole series of details; it does not necessarily follow that I regard these working hypotheses as proved.

I have spared no trouble in trying to bring the work up-to-date, but this is an impossible task without almost infinite resources.

The illustrations have been in almost every case either drawn from nature, photographed direct from the plant, or sketched on the blackboard (from microscope specimens when possible) and then photographed.

I must also acknowledge the kind help of $\mathrm{Mr}$. David Frew, B.A., on many occasions, and of Miss W. Zamorska in the revision of the proofs.

It is my earnest hope that this book may be of real value to all who study plants either for love or for profit, or for both, and that it may suggest to them some of the many interesting problems which are inviting the attack of the British botanist.

\section{G. F. SCOTT ELLIOT.}

28 th Oct., 1902. 


\section{CONTENTS}

CHAP.

PAGE

INTRODUCTION, . . . . . . . . . I I

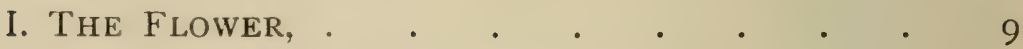

II. Fruits and Colonisation by Seed, • • • 35

III. Colonisation By OTHer Methods, . . . 56

IV. SeEdlings, FOOD Stores AND Germination, • 7 I

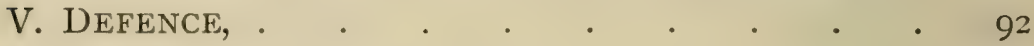

VI. ROOTS AND THE SOIL, . . . . . . . II4

VII. FOLIAGE, • • • • • • • • •

VIII. THE STEM, . . . . . . . . I 58

IX. SEAWEEDS AND THE WATER-FlORA, . • • I75

X. Microbes, Moulds, And Yeast, . . . . I98

XI. FUNGI, . . . . . . . . . . 217

XII. Lichens and THE Rock Flora, . • . . 238

XIII. MOSSES AND LiverwortS, . • • • . 253

XIV. FERNS, FERN-ALLIES AND FOSSILS, • . . 270

XV. The Pine and other Conifers, Alpine Plants, AND THE HISTORY OF THE BRITISH FLORA, . 289

XVI. WOODS AND FORESTS, . . . . . . 303

XVII. The INFLUENCE OF MAN, . . . . . 320 


\section{CHAPTER I.}

\section{THE FLOWER.}

IN the year I 787 , the Rector of Spandau, near Berlin, Kristian Konrad Sprengel, discovered the very important fact that flowers are intended to attract, and probably also please, the eyes of bees, butterflies, and other insects; that they are also agreeable to our taste is a very interesting, but by no means important consequence. The botanists of that time, however, looked upon the differences between flowers as a stamp collector looks on post marks and punctures, that is, as convenient marks by which to arrange their collections, and they neglected Sprengel's discovery.

It is necessary to examine a flower of some kind to explain why this discovery is of such importance in the study of Nature. The flowers of the Whin (Gorse, Furze) Ulex Europaeus or any plant allied to it, such as the broom, sweet pea, or laburnum, will enable any one to obtain a preliminary idea of the meaning of flower structure. Pulling the flower to pieces with the aid of a penknife, it is easy to see that there are five different sets of organs. Those on the outside consist of two small bracteoles and two other much larger hairy pieces which meet and cover the young flower. These latter are the "sepals," and there are in reality five of them, two in the upper lip and three in the lower, but they are so closely united 
that it is difficult to distinguish the separate parts. These are obviously intended to support the flower in its right position, and in the bud they cover over the neatly folded coloured parts and protect them from danger. These coloured parts, five in number, are the "petals," and are intended to attract insects to the flower. The largest is clearly spread out in such a way as to be visible from the greatest possible distance. Within these petals a delicate white sheath is contained, which ends in ten brownish-yellow heads covered with a dusty material. These are the "stamens," the male part of the flower; and the dust with which they are covered is called "pollen." Within the sheath is a green organ, the ovary or "carpel," covered by shining white hairs in front; it obviously resembles a miniature French bean or pea-pod and contains small white bodies called "ovules." These ovules only become secds when the material contained in the pollen dust has united with that in the ovule. For this purpose the pollen dust must be placed upon the extreme end of the carpel where there is a sticky point, the "stigma," to retain it. After being placed on the stigma, it begins to grow and forms a little thread-like tube, which grows till it meets one of the ovules. The living material of the pollen grain then enters the ovule and unites with a part of it. The ovule after this union becomes a seed capable of forming a new plant.

It will be noticed, if a very young flower is opened, that the pollen is scattered with an explosion, the style (the thin drawn out end of the ovary) suddenly springing up, and the dust being thrown out. Thus, if a bee opens the younger flowers, it is sure to get dusted with pollen, and must leave some of this on the stigma of the next flower visited. 
It is quite easy, then, to understand what work the insect does; it carries the pollen from one flower and leaves it on the stigma of another. One might suppose that this is not necessary; the stamens and stigmas are so close together in the flower that one would think the

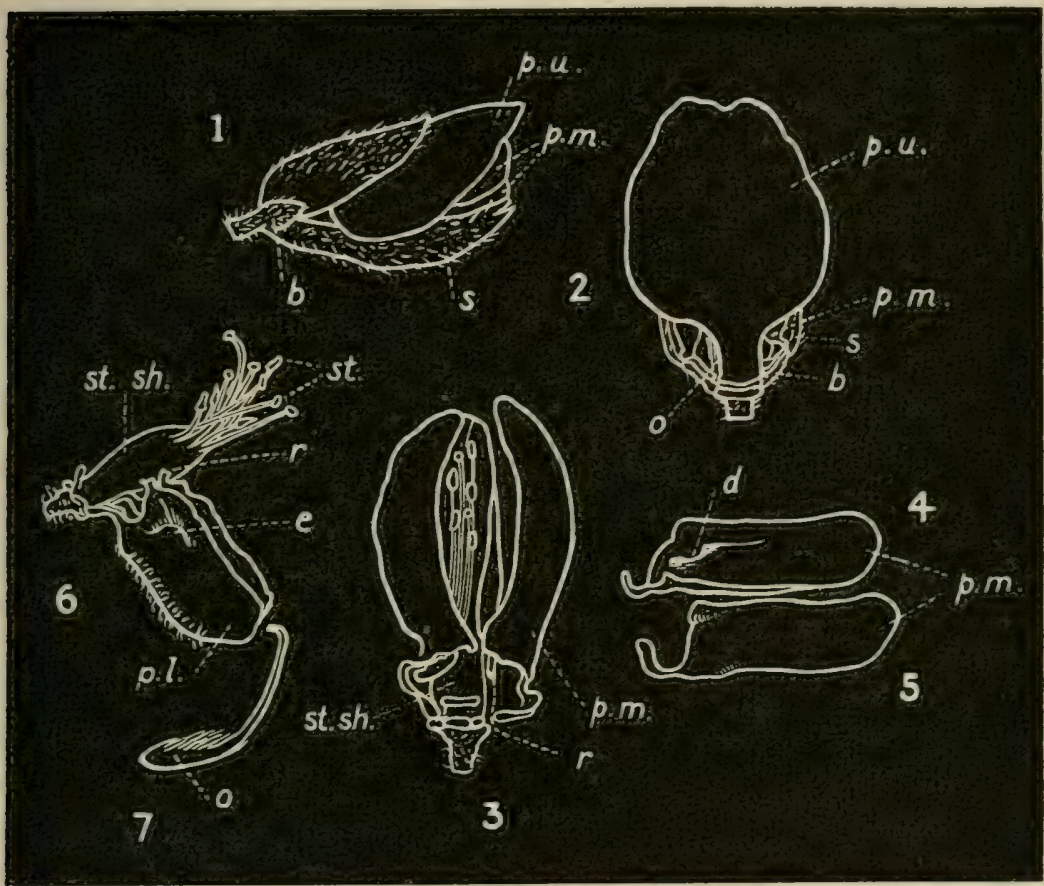

FIG. I.-WhiN (Ulex Europaeus). (I) Young flower seen from the side, (2) from above after removal of upper sepal, (3) from above after cutting away the upper petal, (4) inside and (5) outside views of middle petals or wings, (6) style, stamen sheath and two lower petals from the side, (7) ovary and style, (b) hairy bracteoles, $(s)$ sepals, $(\not, u)$ upper petal or standard, $(p . m)$ middle petals or wings, $(\not . l)$ lower united petals or keel showing hairs along lower edges, $(a)$ deep bulging on the middle petal which fits over $(e)$ ridge and $(r)$ projection of lower petals, $\left(s t . s h_{0}\right)$ sheath formed by union of stalks of stamens $(s t),(0)$ ovary with fine hairs in front.

pollen might be put without trouble on the stigma. But the seed is much more vigorous if it is the result of cross-breeding. It has been discovered by breeders of all sorts of animals,-horses, cattle, etc., - that the offspring is likely to be more vigorous if a cross has been formed and inbreeding avoided. With flowers, fruits, 
vegetables and corn, attempts have been made to do the work of the bees or other insects artificially. The result has been to prove that crossing is distinctly of advantage. Pollen of one kind of wheat, for instance, has been placed on the stigma of a different sort, and the result has been to greatly increase the size and yield of the ears. This has been done by Messrs. Garton of Newton-le-Willows in Lancashire and Dr. J. Wilson in this country, whilst in the United States crossing of this kind is very largely practised. Unsymmetrically coloured flowers, such as the Pansies generally grown in our gardens, are probably due to crossing carried out by insects. The dwarf Cannas also are known to be the result of a cross with a Costa Rican species. The remarkable increase in size and weight found in some of the American dewberries when two varieties have been crossed is particularly worth noting.

It is therefore quite clear that there is a decided advantage in cross-breeding. There is also a danger in continued inbreeding, and thus the insects hovering over flowers or flying rapidly from one to another are really in their service, and are greatly assisting in securing the vigour of the future progeny. They are paid for their trouble either by the pollen, part of which they are allowed to devour, or by the honey which flowers produce entirely for their benefit.

The Whin is a very good example of a flower intended to attract the more intelligent and industrious sorts of insects, such as the humble bee. At first sight there is no visible honey or pollen, as, in the younger flowers, these are quite concealed. The honey, however, will be found inside the base of the large uppermost petal. In the flower of the sweet pea, pollen is left on 
hairs which cover the style and comes out when the bee presses down the two side petals. In the Birdsfoottrefoil the pollen is squeezed out of a small opening at the tip of the two lowest united petals, but in all flowers of this order, Leguminosae, the same general scheme is followed.

The most common characteristics of flowers which are intended to attract the hive bee or humble bee are as follows:

(a) The colour is very often either a deep purple blue, a light blue, or a rich red as in the Aconite, Bugle, Larkspur, Woundwort, Bugloss, and Red Clover.

(b) The honey, again, is often so concealed that only an intelligent creature can discover it. This is well seen in the garden Snap-dragon and the Toadflax, where the petals are swollen out into a sort of lip which has to be forced open by the bee's head.

(c) The flower is almost always rather a large one, so that only insects with a long proboscis can reach the honey. This is easily seen in the Red Campion or in the Ragged Robin, both of which have long-tubed flowers with a little scaly arrangement at the entrance to the tube which prevents smaller insects from forcing their way in. In such cases the length of the proboscis of the humble bee or butterfly and that of the tube or narrow part of the flower are often nearly the same, but generally a certain give-and-take occurs; flowers, in fact, very seldom limit their visitors to one particular species of insect.

The shape of the flowers generally suits the average insect visitor or it is so arranged that all those which are desirable visitors find it convenient. The Foxglove is an exception, for it agrees in shape almost exactly with the body of the humble bee which visits it; and 
one can scarcely escape the conclusion that generations of Bumbles have in some way pressed the foxglove flower out into its present form.

Wasps are very fond of the Figwort (Scrophularia nodosa); they also visit the Common heather, the Snowberry, the Barberry, and Cow Parsnip (Heracleum spondylium). They are amongst the most industrious workers of the insect world. One was observed to work from four in the morning till 7.46 p.m. without a rest. Bees also, when in full work, will visit twenty flowers in a minute, and hence it is not surprising to find so many flowers specially intended for bees and wasps, even though these large and brightly coloured petals must involve the plant in a great expense of material.

Ordinary small yellow and white flowers such as Buttercups and Umbelliferae, where honey and pollen is in no way hidden, seem to be visited by almost every sort of insect, and especially by beetles and small flies (such as Anthomyia), though even the hive bee occasionally gathers pollen from them. Anyone who wishes to realise the abundance of such insect visitors, should choose the morning of a fine sunny day and watch, for instance, a patch of any large St. John's Wort (Hypcricum perforatum, etc.) in full bloom. It will be found that besides small flies and beetles, which are the most frequent visitors, hive and humble bees are by no means rare. There will be also a large number of what one might call the intermediate classes. The most remarkable will probably be the Syrphidae or Hoverflies with yellow bands on the body and a peculiar flight; they remain poised for a few seconds in one place like sparrow-hawks and then swoop rapidly away to a new position, so quickly indeed that the eye can scarcely follow their course. Other flies in which a long sucking 
proboscis can be distinctly seen, such as Rhingia and Empis also occur. There may be beetles which devour the tissues and carnivorous insects as well. It is the fashion in most works dealing with the services of insects to plants to exclude from the list of useful forms those insects which devour parts of the flowers, and those also which live on other flower-haunting insects ; but every kind of insect which is found upon the flower does its share in the carrying of pollen. It is important 1or such observations to remember that one must remain perfectly still for a few minutes to allow the visitors to gain confidence.

The following are some of the most typical flowerclasses, arranged according to the character of their visitors :

(i.) The Veronicas, Myosotis, Geranium molle, and G. dissectum are good examples of Hover-fly flowers. (ii.) The smaller bees are not very important in Scotland. They are found, however, on Compositae, Jasione, Cardamine pratensis, and flowers of a similar type. Very often these bees and the Hover-flies are the special visitors of small pink or blue flowers in which the honey is more or less concealed.

(iii.) Butterflies visit any conspicuous flower, but they are by no means industrious, and readily change from one kind to another. They have a very long proboscis, which is coiled into a spiral, carried under the head when flying. Typical butterfly flowers, therefore, have a long and narrow tube down which the proboscis can go, and also a broad landing-place on which the butterfly can stand during the operation. A good example is the Ragged Robin, of which the "cabbage white" butterfly is very fond.

(iv.) Night-flying moths are much more important 
to the British Flora. For these a white colour is best. as it is most easily distinguished at night, and a strong scent is decidedly of advantage. Lychnis vespertina, the Evening Campion, is a very excellent example. The flowers are not nearly so conspicuous in the daytime as at night, and they, in fact, partly close in daylight, so as to reserve themselves for the evening moths. The scent is also considerably stronger at night. The Honeysuckle is also a very distinct mothflower.

(v.) The hive bees, humble bees and wasps have been already mentioned. It is almost certain that they have an eye for colour, as is shown by the following incident. A weak after-swarm of bees which had been brought up in a blue-striped hive were scattered accidentally. Their dead bodies were found in great numbers at the door of every blue hive in the apiary.

Besides these roughly outlined classes, there are many flowers which have a special clientele of their own.

(vi.) Carrion flies, which feed on decaying animal matters and meat, are probably responsible for the horrible smell and the curious colours of some Arums and Stapelias which are very like the material on which they feed. It is said that these flies are deceived by this resemblance, and actually lay their eggs upon them.

Before mentioning other methods by which plants get their pollen conveyed, it is interesting to note how very closely the insect and flower worlds depend upon one another. Every plant has its own flowering season, which may last for a few days, several months, or even in such cases as the Whin, Dead-nettle, Chickweed and Cerastium, for nearly the whole year. 
The flowering seasons also fit into one another in a very curious way.

On such a shady slope as one finds in any wooded ravine, a regular succession of flowers appears, one after the other, beginning in early spring. The flowers of Ranunculus ficaria open first of all, and are visited by

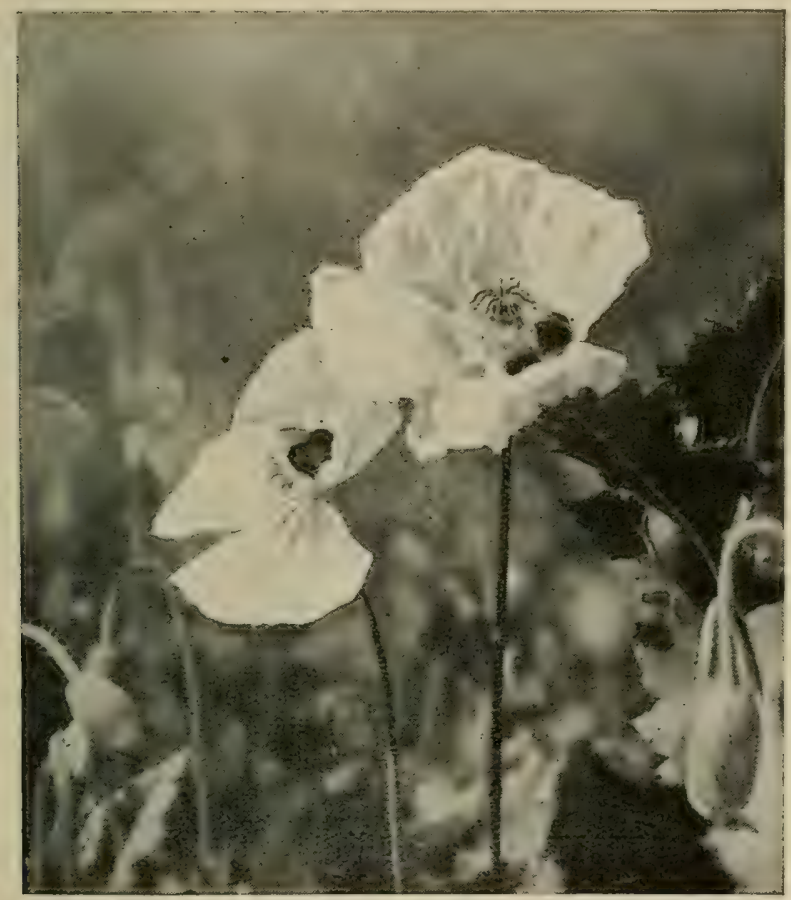

Frg. 2.- Humble bees in Poppy Flowers.

those hardy insects which can resist the cold weather; then Primroses appear ready for the queen Bombus, just as she is beginning to form her nest. Very soon the blue Hyacinth, the Dog's Mercury, and Garlic (Allium ursinum) follow closely one after the other. With the last named most of the sylvan flowers are in full blossom, so that their seasons correspond to the maximum insect population which is found in early S. (B 7$)$ 
summer. Later, Brambles and perhaps a second bloom of Dog's Mercury continue the succession until with the first winter-cold almost everything vanishes. This intermingling of the floral seasons is very distinct in the case of woodland flowers, but it is also easily noticed in cultivated fields, where some weeds flower before the corn or turnips; others, such as the Thistles, flower exactly at the same time, so that their seeds may be sown with the corn; and others, again, spring up and flower in the stubble, or after the turnips have been removed.

Even during the course of one day, the flowersurfaces ready for an insect's proboscis do not remain the same. Linnaeus drew up a Shepherd's clock to illustrate this point, and it has been very well worked out by Kerner and others. Roses open very early in the morning, about 4 or 5 a.m.; Epilobium about 6 or 7 a.m. ; Convolvulus at 7 or 8 a.m. ; Gentians, Veronicas, etc., between 8 and 9 ; Tulips between 9 and 10 . The Centaury does not awake until between Io and I I a.m. Then John-go-to-bed-at-noon shuts its flowers, perhaps not quite at midday, but very early in the afternoon. The Honeysuckle opens and sends out its sweet scent at 6 p.m.; and from 8 p.m. to 3 a.m. such evening flowers as Silene noctiflora are ready for the Owlet-moths.

The net result of this daily and monthly variation, ensures a series of waiting flowers for the satisfaction of any wandering insect.

The close connection of the flower and insect world comes out very clearly also from geological data. Cockroaches existed in the Silurian period. The warm and moist forests of Fern and Club-moss in the Carboniferous epoch were not without insect life, for Mayflies and 
plant-bugs sucking vegetable juices were present; whilst dragon flies, some of gigantic size, with wings two and a quarter feet across, preyed upon them.

Earwigs and crickets seem to have flourished in triassic times. In the chalk period when most of our dicotyledon genera existed, we find bees, butterflies and ordinary flies representing most of the modern types. Mr. Scudder has even shown that butterfly remains are found along with relatives of those plants on which the caterpillars of their modern representatives are now observed to feed.

The point of this history is, that the flower-haunting insects appeared exactly at the time when flowers with honey were developed, which is precisely what we would expect.

It is probable that the original insect would remind us, if we could see it, of a judicious blend of a caterpillar, a millipede and a worm with perhaps a special resemblance to Peripatus capensis. It was composed of pieces, joined together like the coaches of a railway train. Each piece had its nerve-centre and two legs, as well as excretory and other organs. Early in insect history the four or five first coaches were united into a head, and their four pairs of legs became modified into jaws or mouth-pieces. The first pair of jaws has become united into a sort of upper lip in all classes of insects. The flies or Diptera chicfly employ the fourth or hindmost pair of jaws, which has become a long lower lip; that can be, in some forms, greatly extended. The third pair of jaws is used for grasping. The insect will, for instance, seize a piece of pollen with them; the second pair are united to form a single piece.

On the other hand, in butterflies, the third pair of jaws has been greatly elongated, and modified into a 
long suction tube, often, indeed, much longer than the insect.

In the Bee all three pairs of jaws are employed. The second pair are strong biting and masonry tools, and can be pushed out a short distance. The third pair can be pushed out still further, and they carry two side flaps. The fourth pair has also two side-pieces, and a long hairy tongue in the centre. Whilst sucking honey the two flaps of jaws No. 3 and the two side-pieces of jaws No. 4 fit over the floor of the mouth parts and form a suction tube about 6 millimetres long. Before flying the whole proboscis is drawn in and then folded so as to be neatly packed away under the head.

These modifications in the structure of insects are undoubtedly a result of their flower-visiting habits. The effects which insects have had upon flowers is well shown in, e.g. the "Bluebeard" Salvia. In this species, the upper bracts, which are about $\frac{3}{4}$ inch in length, are a rich blue-purple or typical bee-colour. After flying to this very conspicuous centre of attraction, the bee notices the small patches of bright blue on the upper lip of the flower some distance below the bract. This blue is set off by white hairs on the upper lip and yellow on the lower. Thus, in addition to the two-lipped corolla, the peculiar Salvia stamens and other arrangements for insects, four distinct colours are contrasted and arranged in an evidently intentional manner.

But obviously the bee cannot produce colour inside the flower. How these different tints have been formed remains quite unknown. The existing theories upon the subject are so weak and so indefinite, that they have to be covered up and obscured in a very laboriously manufactured and imperfectly understood terminology. It is well known, however, that flower-colour is much more 
brilliant in deserts, at high altitudes on mountains where the sunlight is strong and continued, and also in the far north as at Spitzbergen (Ekstam). It is probable that the colours, white, pink, red, blue, and purple, involve successively greater expense of material. Blue-purple will probably require the greatest amount of sunlightenergy, and white or yellow the least. It is also known that the coloured flowers of a species give off more water in transpiration than the white, and that petals will lose three or four times the amount of water that a leaf does in the same time. The peculiar glossy sheen of Pansies, Gloxinias, etc., is produced by the surface of the petal cells being raised up into little rounded mirrors. The play of light upon these produces the sheen.

So also with scent, which is generally used in flowers for exactly the same reason as colour. The esters or scents are probably due to the action of free acids on alcohols. They are, in the case of Otto of Roses, produced in the epidermal cells of both surfaces of the petals. Mountain air produces a finer and more delicate fragrance, and the scent is strongest when the flower is just opening about 9 a.m. Perfumes form a considerable industry, and the products are very valuable. A kilogramme of Otto of Roses is worth from $£_{28}$ to $£_{32}$; but this quantity would require for its production from two to three acres of Roses. The flowers of wild garlic are said to have a faint hyacinth perfume to attract insects, whilst the leaves have a most disagreeable odour to keep off browsing animals.

However colour and scent originally developed, whether by the sun scorching some individual flowers red in the way in which one often finds the leaves and stems of plants in sunny places red and discoloured, or by 
some other chemical cause, it is clear, as anyone can see by an hour or two's observation in a garden, that the red would at once catch the insect's eye; and that red flowers would be most frequently visited, and hence leave most seed.

The way in which flowers are placed on the stem brings out, very clearly, the fact that an attempt is often made to save the insect as much time and trouble as possible. The diagram shows some of the common arrangements of flowers on the inflorescence, starting with the Tulip, which is perhaps the simplest of all.

From these two sets of inflorescence, it is seen that in three of the largest orders, Compositae, Umbelliferae, and Labiatae, the flowers are brought as close to one another as possible; so that the insect will lose no time in going from one to another. Even in cases in which this is not obvious at first sight, as in the Foxglove and many Cruciferae, the flowers are really very close, and very little time is wasted by the insect in going from one to another. In the Forget-menot, the protection of the young flowers has influenced the arrangement, and they are carefully hidden underneath the stalk until they are ready to take their place exactly in the way of a passing insect. The loose drooping arrangement of the Oat and many panicles is no exception. It is the wind, not insects, which carry the pollen, and the suitability of a loose waving inflorescence for such flowers is quite clear.

(vii.) In addition to insects, other animals are utilised in the transport of pollen. Thus the Golden Saxifrage, in which there are small, inconspicuous, greenish-yellow flowers, is said to be visited by snails or slugs, which crawl over the flat surface formed by the little group of flowers at the top. 


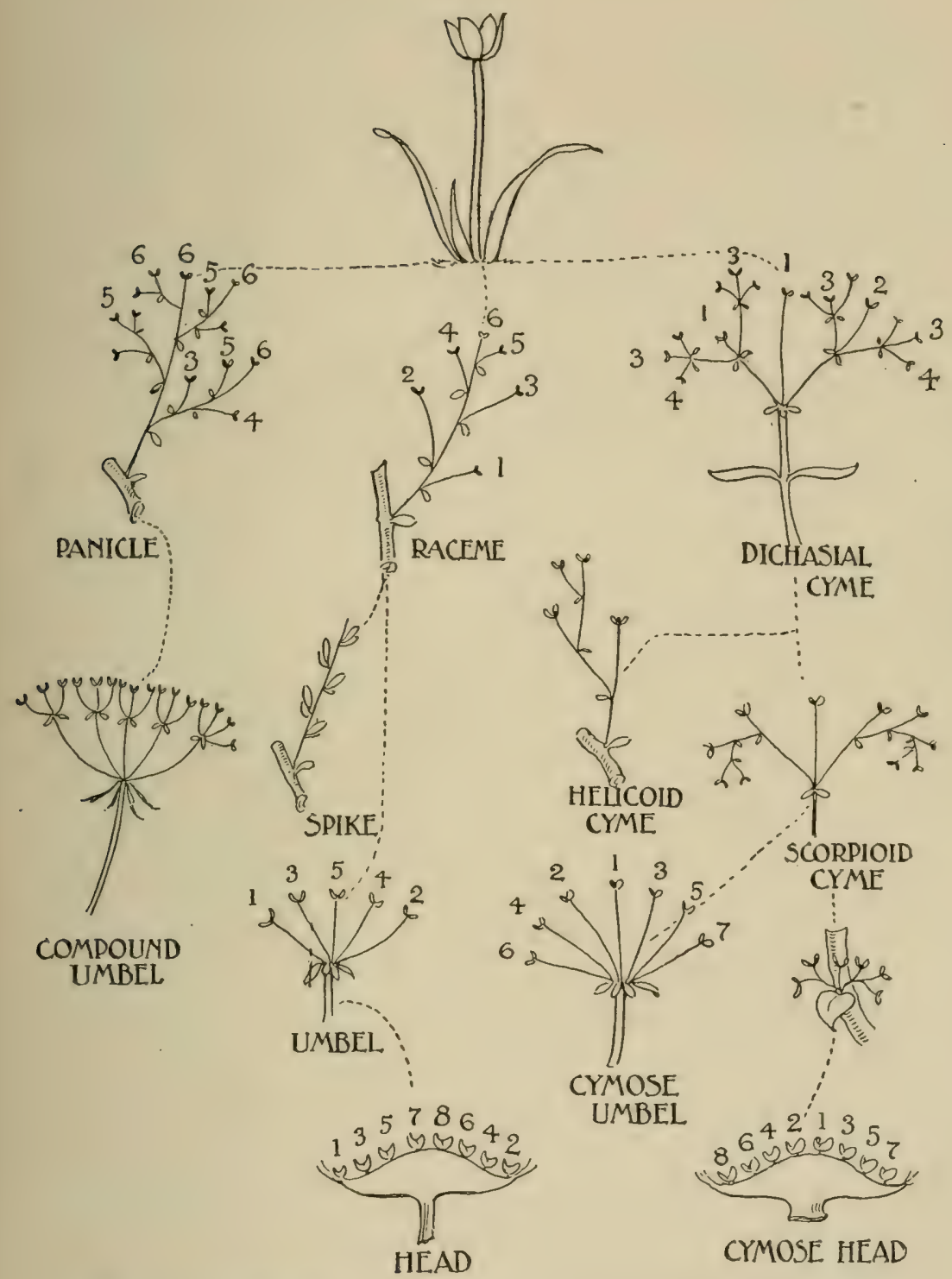

Fig. 3.-Inflorescences. Numbers $1,2,3$ give the order in which the flowers develop. The dotted lines show how the one type can be supposed to change into another by suppression of flower stalks or of pieces (internodes) of change into another by suppression ore characteristic of Umbelliferae; the Head the stem. The two kinds of umbels are characteristic of Unbelliferae; the Head
(capitulum) of Compositae. The Labiatae type is shown between Scorpioid cyme and Cymose head. 
(viii.) Many tropical flowers, such as the Banana, or the beautiful Lobelia cardinalis, are visited by the Sun-birds and Humming-birds. A great proportion of these flowers have a scarlet colour, and a curved tube which exactly fits the head and beak of the bird. Others, which are visited by these beautiful and lively creatures, have the flowers massed together in large cup-shaped hrads, such as the Proteas, or Sugarbush of South Africa, The bird stands on the edge of this cup and plunges its beak into the mass of honey flowers which fills it. There are no bird flowers in the British Flora, at least so far as the writer's knowledge goes; but sparrows can be seen to dip their beaks into the heads of the Ragwort, after insects, and it is very likely that the flower-haunting habits of the Sunbirds began in this way.

(ix.) Bats in the tropics also flutter about certain flowers with projecting stamens, and so carry the pollen.

(x.) Wind is very often utilised for this purpose, and especially in the British Flora. This method involves an enormous expenditure to ensure pollination. The chance of a grain of pollen being blown to the stigma of a flower only one foot away is as the breadth of the stigma to the circumference of a circle with one foot radius, that is probably about $\frac{1}{5 \overline{7}}$, taking the stigma as occupying one-eighth of an inch. But if an insect is seated on the flower it will naturally fly to the next which catches its eye. Plants do, however, produce enormous amounts of pollen. The Paeony has $3,000,000$ to $4,000,000$ grains in one flower, and even the Composite floret may have 240,000 pollen grains.

In Britain, the examples usually given of windpollinated flowers are the Pines, most forest trees, 
Willows, the Grasses, Plantain or Soldiers (Plantago), and the Meadow Rue (Thalictrmin). It is doubtful if any of these plants are entirely confined to wind pollination. Thus Bees often gather pollen from the Willows and Plantago. The pretty colour of the anthers or pollen sacks in Thalictrum and some grasses would lead one to expect that flies visit them, and this can easily be proved by watching, e.g. Sweet Vernal Grass or any of the Meadow Rues, when they are in the pollinating state. A fly, apparently Anthomyia, was distinctly seen by the author using its proboscis upon the anthers of Anthoxanthum. Pine pollen under the microscope is seen to be well suited to wind carriage. Two small swellings, which are little balloons to float the grain of pollen, are found on each side. In the grasses also the stalks of the stamens are very long and hang freely out in the air: the stigmas are very long and covered by long hairs, so as to increase the pollencatching surface. The pollen collects, too, in a little spoon-like curve at the base of the anther, and is only blown away when there is a wind strong enough to carry it a great distance.

A very obvious method of ensuring a cross in these wind flowers, is for stamens only to be formed in one flower, or even on one plant, whilst only carpels are produced by other flowers, or even plants. This is the case in many of our catkin-bearing trees, such as oaks, willows, and so on.

(xi.) Those plants which have been obliged to live submerged in the water sometimes show peculiar modifications. The Sea Grass (Zoster a) has its pollen of the same specific gravity as water, so that it can float freely in any direction, and thus be carried to the stigma. The Hornwort (Ceratoplayllum has anthers which are full of 
air spaces, and which can float in the water, giving out their pollen as they pass down stream. The neat arrangement in the foreign Vallisneria is described in all books on the subject.

(xii.) In the Common Nettle the stamens are rolled up in a very remarkable manner. IVhen gently loosened, or when heated in the palm of the hand, they suddenly uncoil, and a little cloud of pollen is thrown out. This, therefore, is again another method. The elasticity of the stamen-stalk scatters the pollen, which is then carried by the wind. The Barberry has a very curious method of opening its anthers. Instead of a slit being formed to allow the pollen to escape, a small piece at the top is nearly cut off in an oblique manner, forming a sort of valve or cap. The stamen-stalks, or filaments, have a sensitive spot near their base. When an insect's foot touches this, the stalk of the stamen springs up; and, owing to the peculiar valve-like opening of the anther, a shower of pollen covers the insect.

Among the other important points connected with flowers, it must be remembered that they require protection (a) against rainy weather, which would destroy the pollen, (b) against cold, during which no insects are at work, and the pollen would be wasted, $(c)$ against strong sunlight, which might injure the tissues, especially when young, and $(d)$ they must also be guarded against such creatures as the Apple-sucker, Apple-weevil, etc. (see p. 93).

Now the drooping flowers of the Hyacinth, Lily of the Valley, Heathers, Bluebells and Harebells are clearly a very neat and efficient protection against the rain. In almost all the Dead-nettle order, the two upper petals are brought forward as a little roof, neatly covering the 
stamens, and keeping the pollen dry. The curious white scales at the entrance of the Forget-me-not flower also cover the stamens and keep the rain off, whilst the young flowers are hidden away in a little hairy or woolly coil under the stem. In the Flag, or Iris, the three styles (carpel ends) are flattened out and form bright coloured pieces, each of which fits over a stamen and protects it. In Orchids, a sepal and two petals usually form a little roof over the solitary stamen. In Grasses, the stamens and styles are packed away in the most careful manner between two modified leaves or bracts; when bright sunny weather comes, these bracts are made to open by two tiny wedges (probably modified sepals) which swell and force them apart. The stamen stalks grow very rapidly; the entire process of opening may be finished in 20 minutes, so that a few hours' favourable weather may ensure the pollination. The shape of these enclosing bracts is well worth examination. In the Oat, the outer resembles the shape of a boat's hull, and its edges are rolled round over the inner bract, which is very like the deck of such a boat. The cargo, i.e. the stamens and fruit, is therefore very well protected.

Flowers, such as the Tulip, some Buttercups, Convolvulus and Crocus, in which the pollen is exposed, are very sensitive to weather. The Crocus closes whenever the sky becomes overcast, and the others mentioned shut their petals, or sleep, at night, or in dark, wet weather. In a few cases, the stalk of the flower assists in this protection; it droops or bends over at night so that the flower hangs upside down, and will not be injured by rain, etc. The Violet shows just enough curve of the stalk to take the pollen out of harm's way; but in the Tulip and the Wild Carrot the 
stalk bends entirely over, so that rain passes over the back of the petals or flower stalks. In the garden Kniphofias (or Tritomas), the stalk also shows the most extraordinary curvature. Thus, in October, the apex was observed to be doubled over and pointing downwards at Io a.m., whilst it had become nearly straight at I p.m.

In some of the Compositae, the head of flowers closes altogether at night, or in bad weather. This is well seen in Daisies, or in the Carlina acaulis, of which Kerner gives a beautiful figure. On the other hand, for some reason, (perhaps the attraction of insects,) the white ray petals of the garden Pyrethrum, and Yarrow or Milfoil (Achillea millefolium) hang vertically downwards at night.

Such protection is scarcely required in the case of Spurrey (Spergula), in which the flower only lives for five hours, and probably only opens in good weather, nor in that of Rosa arvensis, which only remains open two days. But in the Foxglove (six days) and Cyclamen (ten days), in the cases of the Buttercup (seven days) and Crocus (twelve days), movements of the petals and stalk are obviously necessary to prevent wastage of the pollen.

It is also interesting to find that the opening seems to be regulated by the temperature. Hemerocallis flava is open for one day only in summer time, but remains open for two days in September and for three days in October. The number of insects will be much less numerous in the latter months, as their appearance is also regulated by the temperature.

It has been shown by direct experiment that the pollen is of a hardy and resisting nature in those flowers in which it is naturally exposed, such as Poppies, Lilies and Water Lilies, whilst it is very sensi- 
tive to rain in the Foxglove order, in Fumitories, and in the Potato order, where it is usually well sheltered.

When examining any flower, it is always advisable to observe very carefully the unopened buds. They teach the meaning of many details of the sepals, which, otherwise, are apt to pass unnoticed. Amongst other modifications, hairs are very often found; sometimes the sepals overlap one another or they may have thick, gummy extremities which meet at the tip. In some cases they fit inside one another.

The following are specially interesting examples: (I) The little hairy thickets formed by the young flowers of the Thyme, (2) the Common Buttercup, (3) the Poppy, and (4) the Rock Rose, in which last the sepals are of different sizes. The (5) tips of Bramble sepals also, which are thin and long, twist round one another.

In these flower-buds it is not possible to draw any deninite line between arrangements to guard against weather, and those which protect against destructive insects, or against those unnecessary and useless forms which steal honey. The Black Burdock, Corn Blue-bottle (Centaureas), etc., have their flowers collected into heads, protected by scales which overlap one another and form an outer palisade or wall. The tip of each of these scales has a fringe of stiff hairs, and these hairs form a sufficient entanglement to keep off any honey stealers. Sticky glandular hairs, such as those on the Wild Rose, or on some Saxifrages, can be clearly seen to catch small prowling insects.

The red tips of Daisies, and the black or reddish points often found on the sepals or involucre scales of Composites, are supposed to absorb the light, and thus to afford warmth to the flowers within. These black 
tips are very marked in certain Dandelions and in the Hawkweed of the Alps, where, probably, they are most required and are not at all conspicuous in the Lowland forms.

Very often one may distinguish at the base of the sepals of the Campion (Lychnis diuma), a neat round hole; this is the work of the humble bee, which steals honey by biting this opening in preference to doing its duty by entering the tube in the proper way. It may be that this explains the very peculiar sepals of the Bladder Campion which bulge out to form a sort of bladder. It would be almost impossible for the humble bee to bore a hole in the right direction in this species.

A very interesting figure is given by Kerner in which certain ants are shown in ferocious attitudes on the head of a thistle, protecting the flower against a cockchafer, which insect is a vegetable demon of the most destructive kind. It is said that the honey glands found on the stipules of the Common Vetch (Vicia sepium) attract these ant-guards, but it is not easy to prove the fact by observation.

With a little careful observation, it is easy in almost any example that may be available to get a clearer idea of the meaning of most of the details of the structure of a flower, by taking into consideration the three necessities mentioned above:-(A) pollination by insects, snails, wind, or water; (B) protection against weather; and (C) protection against unnecessary or destructive insects. Engineering necessities for the mechanical support of the flower (D) and (E) considerations of economy must also always be remembered.

It is not possible to give a complete account of these modifications, as the arrangement is never exactly the 
same in any two of the I 70,000 species of flowers known to science, but the following eight examples illustrate the most characteristic modifications of flower structure, viz., irregularity, addition, suppression, cohesion, adhesion, spiral insertion, displacement and modification. (I) One sepal becomes quite irregular in the Larkspur, as it is necessary for it to be brought back into a long spur to hold the honey. The length is very nearly that of the bumble bee's proboscis, being from 7 -I $2 \mathrm{~mm}$. (2) Of additions we have an example in the Poppy, which has an enormous number of stamens, because, being without honey, it has to form a sort of bush of stamens to attract insects. Again, the Grass of Parnassus has no honey, and hence its petals are of two kinds; those of the one type are large and attractive, whilst the others are fringes of hairs which end in glistening knob-like heads: these extremities appear to secrete honey, although they in reality do not, so that insects are deceived into visiting the flower. (3) The suppression of stamens in the female flowers of willows is clearly advantageous for crossing. In Veronica, where there are only two stamens instead of five, the pollination explains the absence of the others, for the usual visitor, a hover-fly, gathers the two stamens under its body to act as a supporting platform while its head enters the flower; any other stamens would be useless or in the way. In the Buckthorn there are only five stamens, and these, instead of being, as they should be, between the petals, are opposite them. The petals are in this case little arched domes which obviously protect the pollen from rain, and hence these particular stamens have been kept out of the ten which the flower no doubt possessed originally. (4) In all cases in which either sepals, petals, stamens or carpels 
become joined, the advantage of this union or cohesion is very obvious. In Lychnis the sepals are necessarily joined, a most unusual character in this order, to support the large petals; if the calyx is cut away the petals at once fall down, being unable to support their own weight. In all such flowers as the Gentian, Primroses, etc., the union of the petals is necessary for three reasons; namely, to hold the flower erect, to form a long tube for the bumble-bee, etc., and to prevent honeystealers entering in. In the Hollyhock, insects alight on the bush of stamens, and obviously here union is strength. As regards the ovary, it is so much more economical to have the carpels joined that there are very few natural orders in which the carpels remain separate. (5) In many flowers the ovary is inferior, that is, the sepals, petals and stamens have become joined to it so that they appear to be attached at the top of the ovary. This adhesion is certainly economical, for no special strengthening material is required for the separate sepals, petals, etc. It is the general rule for the stamens to be attached or adhere to the petals in long-tubed flowers, (it is obvious that the expense of special stalks is thus avoided); but in such cases as the Bell-heather, where they are quite free, it is clearly necessary that they should be so, for the insect is intended to shake the anthers and bring the pollen out of the holes or pores at the tip of the anther. (6) The original arrangement of the flower-leaves (sepals, etc.) was no doubt like that of the ordinary green leaves, namely, in a spiral on the stem; the fact that in all except a very few cases they are arranged in circles may be explained from the economy and better protection which is obtained by their fitting together without interspaces. The original method remains in the 
Buttercup stamens and the petals and sepals of the Water-lily; for, in both these cases, there are so many of these organs that there is no obvious advantage in altering their insertion. (7) Displacement is generally best explained by suppression or addition. (8) The change of petals or other flower parts into honey glands is very common, and metamorphosis for this object may be seen in the following examples.

(I) The stem part, or "receptacle" of the flower, secretes honey in the Mignonette, (2) Sepals secrete honey in the Pelargonium, (3) Petals in Buttercups, (4) Stamens in the Violet, (5) Carpels in Crassula, and (6) base of Styles in Umbelliferae. A great many honey glands are probably due to parts of the flower which have become rudimentary, as in Cruciferae.

Much of the beauty of flowers depends on their engineering mechanism and the perfect balance of the parts. This was realised by the Egyptians in their attempts to copy the lotus bud in their architecture; but the colour has always been an attraction to civilised man, and even to such people as the South Sea Islanders.

The pleasure which mankind takes in perfumes originally intended for the insect world, is best realised from the proportions of the flower industry. In the South of France there are I 800 acres under flowers, and 4,400,000 lbs. of Roses and 5,500,000 1bs. of Orange blossom are used annually.

Anyone who has seen the manufactories of perfume on the Riviera, or realised the enormous capital which is sunk in this industry, or in that of attar-of-roses, must have wondered at the curious similarity in taste between mankind and the insect world.

(B 7 ) 
This similarity in taste is even more marked in the case of colour. Some of us believe that the Red Geranium, which is a great favourite with gardeners, and those artificially selected Double Dahlias which appear at horticultural shows, are not so pleasing to the eye as the simple flowers of Herb-Robert or the Ox-eye Daisy, which have not been affected by cultivation. 


\section{CHAPTER II.}

FRUITS ANI COLONISATION BY SEED.

THE colour of fruits is generally very conspicuous, and contrasts very distinctly with that of the foliage. The dark glossy leaves of the Orange form an excellent setting for its golden yellow fruits. The black of the Olive is particularly distinct against its white shining branches. Nothing sets off a bunch of Rowan Berries so well as the peculiar bluish silver green of the leaves, and the bright colour of Ripe Apples, Hips, Haws, Cherries, Holly Berries, etc., makes it easy for birds to distinguish them even at a distance.

"Some were of burnished gold, Some deep empurpled as the Hyacine, Some as the ruby laughing sweetly red, Some like fair emeralds not yet well ripened."

There is a distinct reason for this. All fleshy fruits are intended to be eaten by animals, which are supposed to carry them off and drop the seed at a little distance from the parent plant.

A thrush or blackbird eating the fruit of the wild Rose, for instance, pecks at the fleshy part, and in the course of its meal scatters the stony fruits over a considerable space, the stiff, rather elastic hairs on these latter probably assisting in the process of dispersal. In other cases, the whole fruit is swallowed, 
and the indigestible seeds are afterwards dropped, perhaps several miles away. It therefore appears that the colours, sugars and fruit jellies, which involve, of course, a great sacrifice of material on the part of the plant, are produced for the sake of colonisation. Fleshy fruits are an excellent example of the care displayed by the vegetable world for emigration. This is a fact of which the modifications described in this chapter afford indisputable proof.

These brilliant colours are not developed till the fruit is ripe. Young fruits remain green, and are not easily distinguished from the leaves until the seed is mature; and both the colour and sugary material appear together. It is obviously not intended that animals should eat the flesh until the seeds are ready for scattering. For this reason also fruits when young are placed below the leaves, and are often hidden by them. These immature fruits are generally sour, and are often decidedly injurious, in this way forming a protection for the seed till it is ready to be scattered.

An Orange is an excellent example of a fleshy fruit, and gives a distinct idea of the different modifications which are to be expected in this particular class. The peel, besides colouring matter, contains a number of little brownish oil glands, which can be seen scattered all over the surface. The oil is bitter and acrid, and, though it is agreeable to the peculiar taste of mankind in the form of marmalade, it is no doubt most distasteful to wasps or small insects, which might force their way through the skin to attack the juicy parts within. If they did so, the sugar would be eaten and the fruit spoiled. Moreover, through the openings made by them, bacteria and fungus spores would enter; and the result would be a rapid decay of the fruit, which neither bird nor 
animal would touch. In all fleshy fruits, similar modifications for protecting the sugar are to be expected. The Lemon, Citron, and, in fact, the whole Orange family, yield a complete series of these essential oils, and a considerable capital is employed in their extraction (oil of neroli and oil of orange flowers, etc., are well-known examples; they are used chiefly in perfumery). The fleshy part of the orange is divided into segments. Each of these segments with the corresponding part of the peel outside itself forms one carpel. The hollow of this carpel is nearly filled by large juicy projections which will be found, on examination, to be attached to the inner wall near the outside; the seeds, which are near the centre, are smooth, very slippery and tough. Their shape is peculiar and difficult to describe. Half the seed, when it is divided lengthwise and through the widest part, is not unlike that part of a duck's body which is submerged when the bird is in the water. The toughness, the slippery character and the shape of the seed, make it difficult for a bird to hold it: the seed will spring away from the bill, and thus be scattered; or, if it is by chance swallowed, the same characters will enable it to pass uninjured through the alimentary tract. Within this tough slippery Seed-coat or testa are the Embryo Orange Trees of which there are several. Each of them has a very minute tip which is the embryo root, two flat, often unequal-sized leaf-like bodies, which are the Seed-leaves or cotyledons, and between them a minute bud which represents the future stem or shoot. The seed-leaves are oily, and contain food material upon which the embryo lives until its own green leaves are produced. In other cases the seed contains a mass of food material in which the Embryo lies, the whole being enclosed in the seed-coat; but in the orange the 
food material is packed inside the leaves of the embryo itself. It is very exceptional to find several embryos in one seed; in this case the struggle for existence begins before the seed germinates, and the strongest embryo generally destroys all the others.

There are therefore besides the embryo five distinct parts in the orange fruit; each for a different purpose.

I. The Peel, with oily matter which protects the sugar.

2. The Colour to attract the animal.

3. The inducement for the animal to eat it; in this case Sugar and Fruit Jelly.

4. The tough Seed-coat which protects the seedling.

5. The Food store of the seedling.

6 . The Embryo or germ itself $(4,5$ and 6 are discussed in Chapters 3-5).

(I) Protection of the sugary material is generally secured by a modification, or extra development, of some of the different weapons which plants employ against weather, or against animal attacks. The orange is closely allied to the Rue family, which is generally aromatic, and it has improved and specialised this family characteristic of producing essential oils. The bloom of the Grape is due to a thin, waxy coat which unfortunately is insufficient to always protect the berries from fungi. The Peach and the Gooseberry have long hairs, and a distinct skin, much tougher in the wild plant than in the cultivated varieties. The apple has a thin layer of corky matter. The Pomegranate, on the other hand, has a thick woody shell, and only a creature with strong teeth is likely to reach the seed. A very peculiar form of protection is that adopted by the Prickly Pear, a cactus common in India. Here the tissue which surrounds the fleshy part is full of minute 
needles of calcimm oxalate, which will wound the lips and tongue of any animal eating the fruit, if it has not sufficient intelligence to extract the juicy part within. These needles are probably intended to keep off slugs and snails, and perhaps also small rodents which would devour the seeds.

For practical fruiterers this defensive bloom is of the greatest importance. Bruising the fruit should be carefully avoided. For example, in packing oranges for transport, every fruit should be rolled in thin paper to prevent destruction of the peel. Even an almost imperceptible abrasion on the skin of an apple, permits bacteria to enter and cause decay of the flesh. ${ }^{1}$

(2) The colours of fruits are, like those of flowers, imperfectly understood. If paper letters are fixed on an apple whilst it is young and green, the shaded parts do not turn red, which shows that the colour depends, partly at any rate, on the fruit being acted on directly by the sunlight. The colour varies greatly, but it is nearly always very conspicuous. Red is the most usual, as is seen in the Hawthorn, Rose, Rowan, and other plants. Yet these reds are not the same. They vary in shade, and always contrast beautifully with the special green of the leaf. The Rowan green is not the same as that of the Rose, and the red varies accordingly. Yellow is often found. Deep black occurs in the Olive, which is set off by the shining white twigs. Blue or blue-purple occurs in the Herb Paris, and among the members of the Solanaceae. Besides its pleasing colour, fruit has also very often an attractive perfume.

(3) The origin of the sugars and fruit jellies is not difficult to understand, at least in a general way, for

${ }^{1}$ The experiment is easily tried and most instructive. 
sugar is the usual form in which plant food (the carbon, hydrogen, and oxygen) is carried about the plant: the fruit jellies are due to a form of cell-wall substance, "pectose," which is developed chiefly in fleshy fruits. The original fleshy fruits have been probably greatly improved by the constant selection of birds or of other animals, which have sought out those they preferred. There is, however, considerable difficulty in understanding certain cases. Such fruits as Guelder Rose (Viburmum) appear to have been in existence in the chalk period, before birds were at all common, or widely distributed. Possibly the Pterodactyls, some of which were not larger than a pigeon, lived upon fruits; but, at present, so many animals are frugivorous that there is no difficulty in understanding the prevalence of fleshy fruits. In addition to birds, the flying-foxes or fruit-eating bats, and many mammalia are largely dependent upon fruits for their food supply. There is, certainly, a great probability that these animals selected fleshy fruits, and thus aided in their development, just in the same way that selection by man has assisted in the formation of the varieties of orchard fruit now in existence.

In different fruits the fleshy part is formed from very different parts of the flower, and the botanical names of fruits, which are given according to the part modified, are very numerous, and occasionally very obscure. Hence in most text-books much space is given to their description. To give information on such points does not enter into the scheme of this work.

It is easy, however, to show that the fleshy part may be produced from almost any part of the flower, and also that the seedling-protection varies in a similar way. 


\begin{tabular}{|c|c|c|}
\hline & Flesh Deveioped from & $\begin{array}{c}\text { SEEDLING } \\
\text { PROTECTED }{ }^{1} \text { BY }\end{array}$ \\
\hline Cashew-nut, - & Flower stalk. & \\
\hline Pineapple, - & $\begin{array}{l}\text { Common stalk of flowers, bracts, } \\
\text { sepals, petals and carpels, - }\end{array}$ & Seed-coat. \\
\hline Strawberry, - & $\begin{array}{c}\text { Stalk-part, or receptacle of } \\
\text { flower, }\end{array}$ & $\begin{array}{l}\text { Carpel (entire } \\
\text { substance of). }\end{array}$ \\
\hline Apple, - & Entire wall of inferior ovary, - & Seed-coat. \\
\hline Grape, & $\begin{array}{l}\text { Entire wall of superior ovary } \\
\text { (carpels), - }\end{array}$ & Seed-coat. \\
\hline Coffee berry, & $\begin{array}{l}\text { All parts of wall of inferior } \\
\text { ovary except inner lining of } \\
\text { carpels, }\end{array}$ & $\begin{array}{l}\text { Inner lining of } \\
\text { carpels. }\end{array}$ \\
\hline Plum, - & $\begin{array}{l}\text { All parts of single carpel except } \\
\text { the inner lining, - }\end{array}$ & $\begin{array}{l}\text { Inner lining of } \\
\text { carpel. }\end{array}$ \\
\hline Banana, & $\begin{array}{c}\text { Inner lining of carpels (inferior } \\
\text { ovary), }\end{array}$ & $\begin{array}{l}\text { Seed-coat (often } \\
\text { absent in cul- } \\
\text { tivated forms). }\end{array}$ \\
\hline Orange, & $\begin{array}{l}\text { Inner lining of carpels (superior } \\
\text { ovary), }\end{array}$ & Seed-coat. \\
\hline Pomegranate, & Outer part of seed-coat, - & $\begin{array}{l}\text { Inner part } \\
\text { seed-coat. }\end{array}$ \\
\hline Yew, & Supplementary seed-coat aril,- & Seed-coat. \\
\hline
\end{tabular}

These fleshy fruits are, however, only examples of one special method of distribution.

The following are the most important of the other methods of culonisation by fruit and seed:

I. Seeds and fruits possess hairs or hooks, which cling to the wool or fleece of animals, or they are

i Protection against the bird's bill or animal's teeth, see p. 38 . 
covered with a sticky secretion, which acts in the same way.

2. Hairs of a light feathery nature are developed on some part of the seed or fruit. The wind catches these hairs, and scatters the fruit or seed.

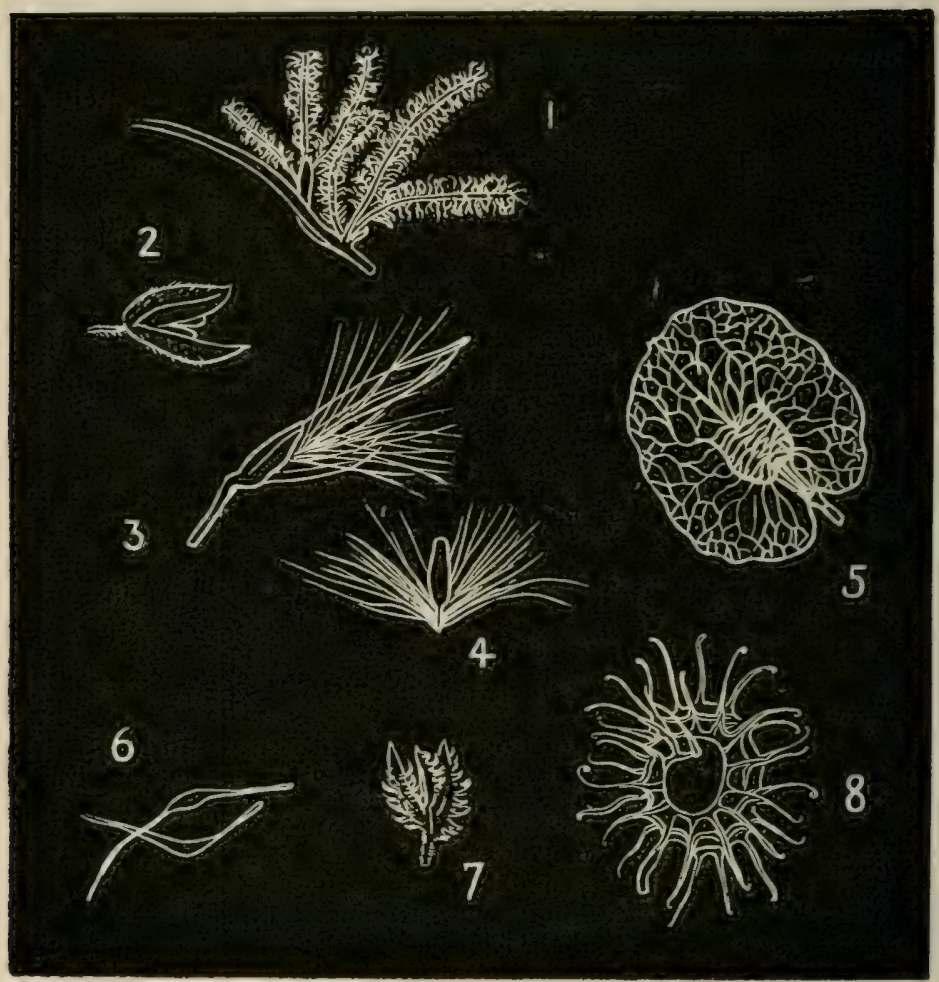

Fig. 4.-Fruit AND SEED Distribution. (I) Wigtree (Rhus cotinus) showing hairs on flower stalks. (2) Yorkshire Fog (Holcus) showing wing bracts. (3) Reed grass (Phragmites communis) spikelet and, (4), single flower enclosed in bracts with windhairs below. (5) Winged fruit of Ptelea trifoliata. (6) Seeds of Bog Asphodel (Varthecium ossifragum) with gossamerlike hairs. (7) A Grass (Tragus) with spines. (8) Pod of Medicago showing clinging hooks.

3. Tings or aeroplanes are developed for the same reason.

4. Special floating tissue is produced so that the seed or fruit can be carried by water. 
5. Elastic or explosive movements of some part of the fruit or seeds throw the seed some distance from the parent plant.

There are two kinds of simple fruits; those in which the fruit opens so that it is the seed that is free to travel to a new position (the dehiscent forms) and the indehiscent, in which the entire fruit (with the contained seeds) is carried away either by wind or by some one of the other agents already named. Very often seeds and fruits show almost exactly the same modifications.

Of the forms with hairs or hooks the common Goosegrass or Robin-Run-the-Hedge (Galium aparine) is an excellent example; the fruit, which consists of two carpels, is entirely covered with small and very tenacious hairs. These cling very closely to cloth, or to an animal's coat, and may be carried many miles before they break and the seeds escape.

Similar, usually hookea, clinging hairs are found on the fruit of Sanicle, of Chacrophyllum Anthriscus, and of a few other Umbelliferae. The sepals of most species of Forget-me-not and of the Agrimony ( $A g r i$ monia Eupatoria), as well as the fruits of Cynoglossum, are covered with hairs which act in the same way. In the genus Medicago (one of the Legmminosae) the pod, instead of being straight, is coiled into a spiral; generally along the edge of this spiral are small stout spines, sometimes curving over, or in other cases diverging in different directions. These pods are very common in sheep's wool, and it is very difficult to get rid of them until the pod decays and permits the seed to escape.

The Burdock (Arctium majus) is particularly interesting, as whole heads of flowers become attached to the fleece of sheep or other animals. In this case each of 
the bracts which surround the small florets and make a sort of palisade round them is shortly curved back into a. strong, though small hook. In South America another Composite, Xanthium, with an even more perfect system of clinging spiny bracts, is sometimes very troublesome. By its fruits the manes and tails of horses are sometimes so thickly felted together that they seriously interfere with the animals' movements.

On the other hand a Composite very common abroad but rather rare in Britain, Bidens, produces three very peculiar harpoons on the fruit. Each of these is a short stiff hair, with two or three very distinct backward pointing parts, like the barbs of an arrow. They are well adapted to stick in the fleece of an animal ; in this case each fruit travels separately.

Perhaps the most beautiful of all these arrangements is that found in the fruit of the common Avens, Water Avens, and also in the garden species of Geum. Here there are numerous carpels which, when ripe, harden into separate dry one-seeded "achenes"; each of these ends above in a slender yet strong spine, which has a very neat $\mathbf{S}$-shaped curve nearly at the tip. The sharp point runs into cloth, fur, or feathers, and the little curve makes it certain that the fruit will be carried off. The grass Setaria is remarkable for its barbed hairs, which are really the stalks of suppressed flowers, and are only of use in carrying the fruit about.

A very rare British plant, Linnaea borealis, has its fruit covered with little sticky hairs, which cling to a passing animal. The seeds of Brook lime (Veronica beccabinga) are covered with a fine gummy layer. The capsules only open in water and the seeds drop into the mud. They are in all probability carried off on the feet or feathers of marsh birds of various 
sorts. It is probable that mud sticking to birds in this way often contains seeds. Darwin found in 63/4 oz. of mud no less than 537 seeds, and Ludwig and other recent observers have drawn up catalogues of the seeds to be found in the mud carried in earth, taken from the plumage and legs of wading birds.

Many foreign plants show the most extraordinary adaptations to this end, e.g. Lappago (Tragoceros), several species of Trifolium, Harpagophytum, Martynia, etc. The capsules of Triglochin should also be examined.

Wind distribution by hairs is exceedingly common in Britain. Every one is familiar with the exquisite crown of feathery hairs which surmounts the fruit of the Dandelion. Almost all Compositae have a somewhat similar circle of simple or feathery hairs, probably the remains of what were once sepals, on their fruits. The wind catches these crowns and carries them sometimes a very great distance. In winter time especially, when the ground is covered by a film of ice, they may be carried a very long way. Wheat grains have been found to travel 165 feet in one minute on frozen ground under the action of a wind blowing at the rate of 25 miles an hour. Hairs used for the transport of seeds by the wind are found in a great many other plants besides Compositae. A few of these are mentioned to show that the hairs may be developed from very different parts of the flower. The Cotton grass, which is really one of the Sedges, Cyperacere, has a quantity of long silky hairs produced from both sepals and petals; the little hard fruit is seated upon and amongst these hairs. In the Travellers' Joy (Clematis), some Anemones, and the little Alpine Dryas (Rosaceae), the carpels terminate in a long and elegant silky tail, which is covered all over by hairs, and thus catches the 
wind. In some Grasses, such as Melica and Calamagrostis, a bunch of fine hairs is formed upon the bracts. In the Bulrush (Typha) the tall upright flowering stalks are densely covered at the top by very minute woolly flowers; on close examination it will be found that each minute fruit has a short stalk, and that the woolly hairs spring from this little stalk or "pedicel."

It is very remarkable that there are also cases in which seeds, not fruits, develop hairs for the purpose of aiding in their transport by the wind; and sometimes these have an extraordinary resemblance to the hairs found on fruits. The Willow Herb or Epilobium, for instance, has numerous small seeds; each of them has a tiny crown of hairs; and, at first sight, one would at once consider the seed to be a Composite fruit with a hair-pappus. The seeds of the Willow also have an irregular tangle of hairs around them. When the capsules open, these seeds drag each other out of the capsule by their interlaced hairs; and the wind then carries them away gradually. A very peculiar seed is that of the Bog Asphodel (Narthecium ossifragum); two long and very thin hairs extend from each end, and these are probably intended to catch the wind. These arrangements of the plant for the dispersal of the seed have been taken advantage of by man. The best known case of this is, of course, "Cotton," in which the hairs that cover the seed, once used to catch the wind, have been employed by mankind for textiles, certainly since 800 B.C. (see bibliography), and probably since long before that time. Dr. Watts mentions an ancient fable in British India to the effect that the first man was pulled out of the depths of the earth by a cotton rope in the hands of the demigod Sraccarlo. The length, tenacity, and uniformity of cotton hairs probably ensure 
the distribution of Cotton by man; for, as long as man continues to use clothes, no other textile is ever likely to replace it.

The third series is even more interesting, as the idea of wings or aeroplanes lends itself to a greater variety of treatment. These have been recently classified by Dingler (see p. 49). Sometimes these wings form a parachute, in other cases they act like sails. The seed may be flat, with a continuous wing as in many Lilies, or there may be three wings running longitudinally, as in the fruits of Polygonaceae. The Ash has but one broad wing. The arrangement in the Sycamore fruit and Pine seed is one of the most beautiful, and at the same time, perhaps the most difficult to understand of any of them. Each carpel of the former ends in a long, slightly twisted blade much broader than the fruit. There are generally two of these carpels attached together. When they begin to fall, these flat wings press upon the air, and, in consequence of the position in which the weight is slung, moments are set up which cause the system to twirl round and round as it falls. The motion is curiously similar to that of the screws of a steamer, but whilst in the latter the turning of the screw causes the motion of the boat, in the sycamore the motion of the fruit as it falls causes the twirling of the wings. This, however, is not a scientifically exact explanation, for which advanced mathematics are required. A very neat little parachute is found in the Sea Pink or Thrift (Ameria vulgaris), where the fruit is surrounded by a thin papery funnel intended to catch the wind. In Dipsacus, a very similar funnel-like parachute occurs, but it is formed from the bracts, and not, as in Ameria, from the united sepals. 
The broad concave bracts of the Hop contain a single fruit, protected by peculiar little yellow glands which prevent animals from eating it. Each bract is blown off by itself and carries the fruit to a considerable distance. Several grasses have similar wing-like bracts; of these perhaps the Quaking Grass is the best known. In the Hornbeam both the bract and two bracteoles are used for a parachute. The Lime uses only one large flat and very thin bract, which is attached to part of the flower stalk; from this hang the small nuts, at such an angle that the wind must carry the fruit some distance before it drops to the ground. The principle is that utilised in kite-flying.

In the following cases the elasticity of the stalk is of great assistance to the wind in dispersal. The Cow Parsnip has two flat and thin wing-like half-fruits, hung from the top of the fruit-stalk, which carries them. If the whole inflorescence is bent over in the way in which it would be carried by an animal passing, it springs back as soon as it is set free and the fruits fly off. Thereupon they are caught by the wind, which, assisted by the momentum due to the elastic springing back of the stalk, may carry them a distance of six feet or more from the parent plant. The very curious shape of the fruit of Angelica, and the flattened character of the Woad fruits (Cruciferce), show that they are dispersed in the same way.

Many seeds also have curious membranous wings around them. Thus, for example, Bignonia, various Lilies, Honesty, and the Yellow-rattle, all have a thin papery border round the seed. In the two last the stalk of the inflorescence is very elastic. The wind is sure to catch on the broad pods (siliculas) of the Honesty, and the flat wide fruit of the Yellow-rattle; and in a high 
wind the seeds become jerked loose, and are scatiered in every direction. But the wind is not essential, for anything which bends the stalks over gives, on the rebound, enough throw to send the seeds a long distance. Orchid seeds have occasionally very beautiful thin membranes, but the seeds are generally so minute that the wind can easily blow them to a great distance. The seeds of one species in fact weigh only $\frac{2}{100}$ th of a milligramme, about $250,000,000$ would be required to make a pound weight, so that the proportion of weight to the surface film of air is exceedingly small.

The effect of these hairs and wings has been tested. Thus the fruits of an Artichoke in one of Dingler's experiments took 7.8 seconds to fall a distance of six feet to the ground, but after the hairs were removed they only took I.2 seconds to fall the same distance. Bignonia seed fell six feet in 24.6 seconds with their wings and in 4.6 seconds without. The Maple took 5.6 seconds with and only I.2 seconds without its wings.

The elasticity of the stalk of the inflorescence is, as we have seen, often of great importance. Very frequently, owing to the way in which the fruit dries, the carpels become strained, and on being set free suddenly spring out in such a way that a jerk may be given to the seed. The Broom is the classical example, for Bock described the scattering of its seeds in I 546. The two halves of the pod suddenly break apart with an explosion, and the seeds are scattered in all directions. Several other Leguminosae act in the same way, notably the Whin, whose seeds are very often jerked three or four feet away from the parent plant. In the Herb-Robert and other Geraniums, the five carpels are arranged in a circle, and their long pointed ends are united into a common stalk in the centre. When ripe each carpel splits 
away from its stalk, and, coiling up as it does so, sends the seed flying to a considerable distance. Lubbock's excellent account of the way in which these and other British plants disperse their seeds should be consulted. The catapult arrangement found in many Labiatae, depends upon the stalks or pedicels of the separate flowers; when these are bent down they suddenly spring up, and the nutlet is thrown out of the calyx and carried to a considerable distance. Sometimes a circle of hairs in the calyx acts like the rifling of a gun, and gives the seed a turning motion as it starts. But, perhaps, the most remarkable case of all is that of the Woodsorrel, which has a little cup-like covering to its seed, really an aril or supplementary seed-coat. This is highly elastic, and when drying suddenly turns inside out, jerking the seed a long way off from the parent plant.

In many grasses, and in the Storksbill, the hygroscopic property of certain thin dry tissues of the bracts or carpels by which they twist or untwist as the air changes from wet to dry is utilised in a most remarkable way in the dispersal of seed. Avena sterilis, Lagurus ovatus, and several species of Stipa, are good examples. In these one of the bracts enclosing the fruit possesses an extremely long spine or awn, which is abruptly bent at an angle. If put in a tumbler of water this awn slowly moves until it is quite straight. If it is then held near a candle or heated surface it dries, and suddenly whirls round and round, curling into a corkscrew spiral at the bend.

If one examines the part which contains the seed it will be found that it ends at the base in a sharp and very hard tip, whilst further back there are stiff and rigid hairs pointing upwards. 
In, for instance, Stipa capillacea, the azon is very sensitive to even slight changes in the moisture of the atmosphere. If it should happen to fall on a sheep's back the free end of the awn catches on the wool, and as it twists and untwists, must force the sharp point at the base of the glume into the skin ; the rigid hairs alluded

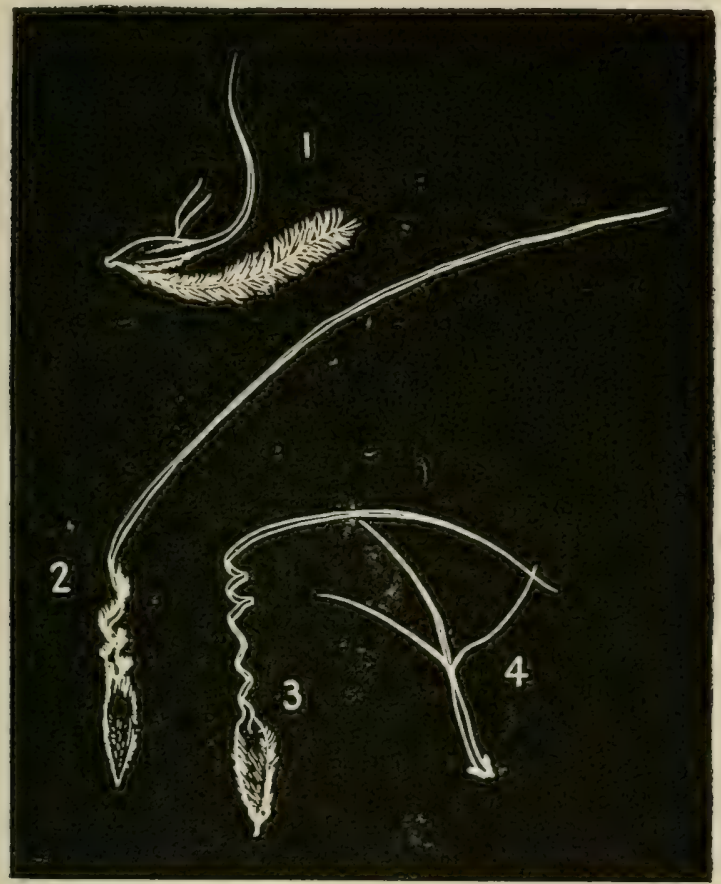

FIG. 5.-Hygroscopic Aivns. (I) Harestail Grass (Lagurus). (2) Stipa spine. (3) Storksbill (Erodium) carpel. (4) Aristida sp.

to prevent its ever being withdrawn, so that every change of the twisting awn forces the sharp point down into the skin; and, as a matter of fact, sheep are killed in this way. This species is found in Russia, but strangely enough three other sheep-killing grasses are known which act in precisely the same manner. One Heteropogon contortus in New Caledonia, another Aristida 
hygrometrica in Queensland, and another in North America, the Porcupine Grass (Stipa spartea). The ordinary function of these twisting awns is, of course, to bury the seed in the ground; the process is easily shown if the dry fruit of Avena sterilis is placed in a drop of water on a table. It will also show the peculiar motion when left to dry.

Not very many plants show special adaptations to water transport, although most of those which grow in water or marshy places float easily in consequence of the numerous air cavities in their tissues. Hence any part broken off may carry the fruit a long distance. In the White Water-lily each seed has a small envelope, or "aril," which is full of air cavities of this kind, so that the seed can float for a short time. In the Yellow Waterlily (Nuphar) the carpels themselves float. The Cocoanut is a well-known example of a floating fruit: the nut itself or shell is really the inner lining of the carpels. The middle part of the carpels has become a mass of light fibrous material, "coir," much used in brushmaking. The outer layer of the carpel is a thin white skin which covers the whole fruit. It is therefore very buoyant and can float for a very long time. As a matter of fact, even quite recently formed atolls in the Pacific soon become inhabited by cocoanuts, whose fruits have drifted to them.

The table here given shows how very varied are the parts of the fruit or seeds which are utilised for transport.

It is impossible to explain one difficulty brought out very clearly by this table, namely, how these specialised arrangements come to be formed exactly where they are required. Why should the awn of several grasses, and the carpel of the Meadow Crane-bill become hygro- 


\begin{tabular}{|c|c|c|c|c|c|}
\hline $\begin{array}{l}\text { MODIFIED } \\
\text { PARTS. }\end{array}$ & $\begin{array}{l}\text { Hairs to } \\
\text { catch Wind. }\end{array}$ & $\begin{array}{l}\text { Wings to } \\
\text { catch Wind. }\end{array}$ & $\begin{array}{l}\text { Hooks or } \\
\text { Clingers for } \\
\text { Fleece, etc. }\end{array}$ & $\begin{array}{l}\text { Water } \\
\text { Carried. }\end{array}$ & $\begin{array}{c}\text { Elastic } \\
\text { Properties. }\end{array}$ \\
\hline $\begin{array}{l}\text { Stalk of } \\
\text { flower }\end{array}$ & Bulrush & - & Setaria & Lemna. & $\begin{array}{l}\text { Labiatae } \\
\text { etc. etc. }\end{array}$ \\
\hline Bracts & $\begin{array}{l}\text { Melica } \\
\text { Calama- } \\
\text { grostis }\end{array}$ & $\begin{array}{l}\text { Lime } \\
\text { Hop }\end{array}$ & Burdock & $\begin{array}{l}\text { Fruit of } \\
\text { Carex? }\end{array}$ & $\begin{array}{l}\text { Awns of } \\
\text { Stipa }\end{array}$ \\
\hline Sepals & $\begin{array}{l}\text { Composite } \\
\text { Pappus, } \\
\text { Valerian }\end{array}$ & Armeria & $\begin{array}{l}\text { Myosotis } \\
\text { Agrimony }\end{array}$ & - & - \\
\hline $\begin{array}{l}\text { Carpels } \\
\text { (superior } \\
\text { ovary) }\end{array}$ & $\begin{array}{l}\text { Clematis } \\
\text { Dryas }\end{array}$ & $\begin{array}{l}\text { Maple } \\
\text { Woad }\end{array}$ & $\begin{array}{l}\text { Medicago } \\
\text { Geum } \\
\text { Cyno- } \\
\text { glossum }\end{array}$ & Nuphar & $\begin{array}{l}\text { Broom } \\
\text { Geran- } \\
\text { ium }\end{array}$ \\
\hline $\begin{array}{l}\text { Wall of } \\
\text { inferior } \\
\text { ovary }\end{array}$ & - & $\begin{array}{l}\text { Hera- } \\
\text { cleum }\end{array}$ & $\begin{array}{l}\text { Bidens } \\
\text { Sanicle } \\
\text { Carrot }\end{array}$ & - & $\begin{array}{l}\text { Squirting } \\
\text { Cucum- } \\
\text { ber }\end{array}$ \\
\hline Aril & Epilobium & Pine & - & $\begin{array}{l}\text { Nym- } \\
\text { phea }\end{array}$ & Qxalis \\
\hline $\begin{array}{l}\text { Seed- } \\
\text { coat }\end{array}$ & $\begin{array}{l}\text { Willow } \\
\text { Strophan- } \\
\text { thus }\end{array}$ & $\begin{array}{l}\text { Yellow } \\
\text { rattle } \\
\text { Bignonia }\end{array}$ & $\begin{array}{l}\text { Villarsia } \\
\text { Veronica } \\
\text { becca- } \\
\text { bunga. }\end{array}$ & $\ldots$ & - \\
\hline
\end{tabular}

scopic; and why should the rather unusual "arils" of the Yew, Woodsorrel, and White Water-lily become specialised for dispersal? Hairs, and even hooks or clinging parts are by no means uncommon, they are indeed characteristics of certain orders; but these special modifications, which, it must be remembered, are only of use when they are perfectly 
produced, and could be of no value till they had become complete, cannot be brought into line with any theory.

It only remains to mention a few unusual, and decidedly special, cases of arrangements for seed dispersion. The seeds of the Cow-wheat (Melampyrum) are exceedingly like the larvae of certain ants, and it has been found that they are actually carried about as larvae by the ants and thus distributed. The squirrel makes a store of nuts, and sometimes forgets where they have been placed, and in this way Oak and Hazel nuts are not infrequently dispersed. The crow also carries acorns about, and drops them in a new position; uninjured seeds of Potamogeton natans, Chenopodium album, Euphorbia helioscopia, etc., are also said to have been found in birds' crops. These, of course, might germinate if thrown out.

Drifting wood may carry seeds, or even entire plants, over wide distances. Sloane in 1695 recorded the occurrence of Guilandina Bonduc on the coast of Ireland, and $\mathrm{R}$. Brown mentioned that the seeds germinated. It is not at all impossible that the Eriocaulon Angusti folium, found in the Hebrides, reached Britain in this way. Other plants, such as the common Shepherd's Purse (Capsella), produce so many seeds that, although these do not show any remarkable adaptations, the plant has, nevertheless, a much greater chance of reproduction than plants in which only a few seeds are produced, though these have a very complete mechanism for dispersion. These plants, like the rabbit, survive in virtue of their great reproductive power. Thus Pimpinella integerrima will produce some 29 umbels, with, on an average, 1600 fruits (Harshberger) or 46,400 ( 92,800 seeds) in the year. Capsella, in which 
there are not infrequently four generations in a year, may produce 10,000 to 30,000 fertile seeds.

Man himself is responsible for great vegetable migrations: not only his own cultivated favourites, but many weeds are carried inadvertently by him. From the economic side, this carrying of weeds is of great importance. In America much careful observation has been directed to the seeds of common weeds; and the results of these observations are to be found in the United States year-books of agriculture. It can scarcely be denied, that the untidiness and wastefulness of man is solely responsible for a large number of these agricultural pests. Railway trucks, the packing of cases in which all sorts of goods have been conveyed, and waste products of any kind are all capable of greatly damaging the crops.

Often the seeds of weeds closely resemble cultivated forms. The seed of Agrostemma Githago is much like a grain of wheat, and several wild Avenas have fruits very like those of the Common Oat. Quite apart from this economic side of the question, which, it may be remarked in passing, is wholly neglected in Britain, is another very important deduction. It has been shown in this chapter that, on the emigration of the young, plants seem to spare no sacrifice of material. To further this, colour, scent, all sorts of beautiful flying and clinging organs are produced in abundance. It is very difficult to discover any plant which, after close study, is found to be without some special arrangement for carrying the young plants away. They are never supposed to remain on the ground where they would infallibly come into collision, and compete with, their long-established predecessors. 


\section{CHAPTER III.}

\section{COLONISATION BY OTHER METHODS}

VERY often, plants are enabled to occupy new ground through some special method of growth, or by means of some specialised part (not fruit or seed) which has been developed for the purpose. Sometimes the whole plant is carried to a new place, to which it is either blown by the wind, or floated upon the water. Among plants so transported may be mentioned Manna (Lecanora desertomm), and other lichens of the Syrian desert, which, in dry weather, are blown over considerable areas, and sometimes heaped up in great quantities.

Of other plants, perhaps the best known is the so-called Rose of Jericho (Anastatica Hierochuntica). When dry, the whole plant curls into a sort of spherical ball; then it is said to be torn out and carried away by the wind, but if it should reach a moist place, or be placed in water, the withered-looking branches uncoil, and the plant takes root and produces flowers and fruit.

There are quite a number of water plants which, throughout their lives, remain unattached, floating freely, and carried about in the water. The small Lemna, for instance, which has tiny green fronds flattened out in a leaf-like manner, floats on the water and obtains all necessary salts by means of long 
absorbing roots. The Bladderwort (Utricularia), the Frogbit (Hydrocharis morsus-ranae), Salvinia, Azolla, and the Florida Hyacinth are all similarly independent, and are never attached to the ground. They are easily carried about by the current; and sometimes show an extraordinarily quick rate of multiplication. For example the Florida Hyacinth (Eichhomia crassipes), a native of tropical South America, was introduced into the St. John's river about I890. In I 897 it had increased to such an extent that large steamers were rendered helpless through the plants becoming entangled in their paddle-wheels; timber rafts could not be brought down stream; and net fishing was stopped altogether. Its chief peculiarity lies in the way in which 20 or 30 plants remain attached to one another by the long runners, rather like those of the strawberry. The petioles of the leaves also are greatly swollen, and act as very efficient buoys, preventing the plant from being overturned.

Pistia stratiotes also floats in water. There is a special enlarged part of the leaf which acts as a buoy. Many other water plants, although they are normally attached and rooted in the mud, seem to be very slightly affected by the loss of their fixed base. Any part that has been broken off and remains floating in or upon the water, seems to obtain all that it requires, and even to increase and multiply without any trouble.

Nor is this difficult to understand, for the skin of both the leaf and stem of water plants is, as a rule, scarcely at all thickened, so that water can enter over the whole surface, and a root is not generally essential. There is, in fact, a tendency in plants to lose in water the hard outside thickening which is 
the special peculiarity of the skin or epidermis of all land plants.

The Canadian weed (Elodea Canadensis), which has managed to establish itself in ditches and canals throughout a large part of Europe, is said to have escaped out of a botanical garden about I830-I 840 . The first record for Britain seems to have been "in the canal at Foxton Lock, Market Harborough," by Miss Mary Kirby in 1847 , but in the comparatively short interval of seventy years it has become so common that no one would suppose it to be an introduction. Yet it never produces seed in this country, and spreads entirely by non-sexual means. A broken branch puts out new roots and develops, without difficulty, into a new plant, as healthy as its parent.

It follows that the branch which is separated must contain within itself a certain amount of food material, on the strength of which it is able both to produce these new roots, and also to wait until they are ready to perform their work.

As a matter of fact, leaf, stem and root generally contain a certain reserve of food as well as of water. Thus, the leaf of a Begonia, if separated from the plant and properly treated, will produce buds which may develop into a new plant with flowers and seeds. Willow and Geranium cuttings are simply cut off branches. The stump of an ordinary tree, such as the oak, will throw out branches, which may become trees, quite as large as any that are formed by seed.

This property is of great importance to mankind, because many varieties of cultivated plants do not seed freely, and may, perhaps, take a very long time to mature; whilst by these methods of propagation a new plant, which retains all the valuable properties 
of the original, can be produced in a very short time.

Thus, for at least 2000 years the sugar cane has been invariably grown by means of "suckers" springing from the base of the original stem. The cane sugar is stored up in the stem as a reserve of food for the production of flowers. Just before flowering it becomes converted into the comparatively useless grape sugar. The priests in India, probably to discourage delay in cutting the canes, invented a superstition that, if the proprietor saw the flowers, he would himself die within the year; his wife and children would beg their bread, and his entire property be confiscated.

As a matter of fact, it is now difficult to get the cane to reproduce itself by seed; and it is only within recent years that the attempt to do so has been successful. The plant has, in fact, become so weakened by continual cultivation without sexual fertilisation, that it is necessary to start a new form.

The last consideration brings out clearly an important point. Whenever a plant is formed by any one of these "cutting-" or "layering "-methods, it is simply a part of the original individual, and not a new one. The present sugar-cane plantations are occupied, therefore, by portions of one original individual, which is at least 2000 years old, so there is no wonder that it is showing symptoms of senile decay.

Even the Potato, after some 400 years of cultivation, is becoming delicate, and seedlings have frequently to be produced with a view to hardening its constitution. Thus new sorts are introduced, such, for example, as the "Early Rose" of the United States.

The methods of non-sexual reproduction depend on the formation of special roots, branches, buds, or 
even leaves. The buds are not of very great interest; the winter buds of water plants, the bulbils of Polygonum viviparum, those of Saxifraga granulata and of some Garlics (Allium vineale, $A$. Scorodoprasum $A$. oleraceum, etc.) are the most important. The Saxifrage "bulbils" are small, round, white bodies, which can be easily seen at the base of the stem; they are produced instead of ordinary branches; those of the garlic are about the size of a pea. They are solid and fleshy, and occupy the position of the flower stalks which they replace.

Leaves are seldom used for non-sexual colonisation. The common Ladies' Smock (Cardamine pratensis), however, often forms roots and a bud on its lowest or basal leaves, and these may produce a new plant. Some species of Sedum throw off both the leaf and the small bud within it, and this "off-shoot" forms a new individual. The Begonia is regularly propagated by dividing, and sowing parts of its leaves.

On the other hand, leaves are frequently employed to store up food material over the winter. The Woodsorrel, for instance, has a very thin, delicate creeping stem, along which little triangular fleshy bodies may be seen. These are the bases of old leaves and contain a reserve of food. The bulbs of the onion, and all the varieties of Allium, such as leeks, garlic, shallot, etc., as well as most of the Lily order, also store up their food in the fleshy base of the leaves. Generally a protecting outer coat is formed from the withered and dry base of the outermost leaf, and this covers and protects the rest; but, in some cases, each fleshy scale ends above in a hardened tip, and these hard extremities form a protecting mosaic, covering the surface of the bulb. Two very well-known ferns, the "Mother of Thousands" and the "Walking Fern" use 
their leaves for colonisation. In the first, Asplenium bulbiferum, the leaves carry on their margins numbers of little fern-buds, which eventually fall off and take root (cf. Sedum, v.s.); in the second, A. rhizophyllum, the tip of the leaf dips into the soil and there develops a root from which a new fern is formed. This last, therefore, acts exactly after the manner of a Bramble, though it is the leaf and not the branch which colonises.

There are but few examples of roots being used for propagation. It is, of course, a special characteristic of roots not to produce either leaves or buds, yet there are many exceptions. The China Grass or Rami (Boehmeria nivea) is multiplied by dividing the roots, and Crab Apples, Medlars, Roses, Azalias, and of course the Dahlias, may be grown from pieces of root sometimes only two inches long. In fact Goebel has recently shown that the root itself may change into a foliage stem in the case of two ferns, Platycerium and Diplazium (Asplenium esculentum), and in Listera cordata, Neottia and Anthurium.

The Banyan and Mangrove send down vertical roots from their horizontally spreading branches; and these roots become supporting trunks, and enable the tree to extend its area very greatly. One Banyan, in Ceylon, forms a grove said to be capable of sheltering 5000 men. The Mangrove is of economic importance on the muddy foreshores of such tropical countries as West Africa, for these roots occupy and gradually fix the shifting mudbanks. The roots are much branched, and thus intercept all the silt and floating debris which collect about them. Eventually the accumulations result in the formation of new land, sometimes of great extent; for as soon as the mud, etc., has raised the soil above the level of high tide, 
ordinary jungle trees kill out the mangroves, and take their place.

The greatest variety and ingenuity is, however, shown in the modifications of stems and branches. Generally, stems are, of course, upright or vertical; and the only possible way of utilising branches to spread the plant is after the manner just described for the mangrove and banyan. But, very often, the stem grow's obliquely; as,

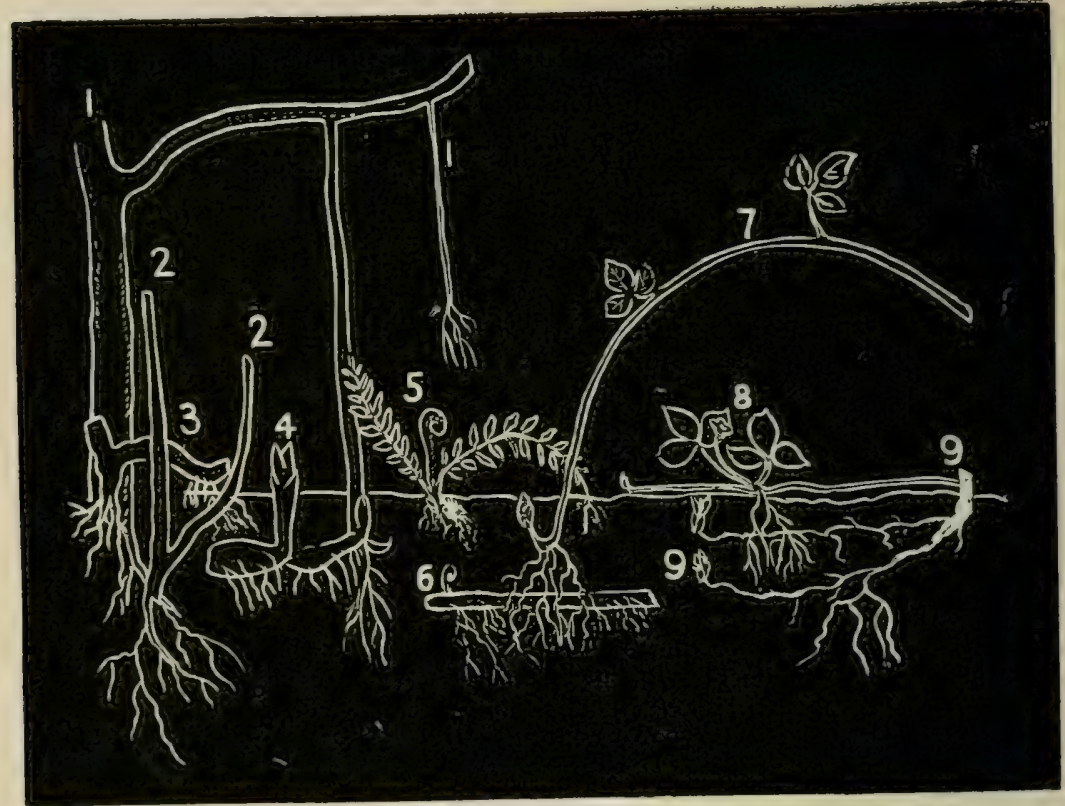

Fig. 6.-Diagrams of Non-sexual Methods of Colonisation. ( $x$ ) Mangrove or Banyan. (2) Suckers of Rose, etc. (3) Branches (rooting) of Gooseberry. (4) Iris "rhizomes" (sympodial). (5) Walking Fern with leaf rooting. (6) Bracken rhizome (indefinite growth). (7) Rooting branches of Bramble (8) Runners of Strawberry. (9) Roots producing buds of some Rosaceae.

for example, is the case with the Male-fern, which lies, half buried, on the ground and inclined at a slight angle to its surface. In this case the buds, or young branches, are given off from the parent stem in a position which permits of their rooting themselves without any difficulty in untouched ground. On the 
other hand, the stem of the Bracken is almost perfectly horizontal, and is buried below the ground at a considerable depth. Every year it grows forward a few inches and both leaves and roots appear in a new position.

The diagram here given illustrates some of the different methods of colonising by branches or stems.

In the Strawberry and Silver-weed (Potentilla Anserina), the branches given off from the main stem are prostrate, or flat on the ground. They root themselves at the tip, forming a new plant. Thus a new base is occupied, and another branch or runner is pushed forward, often in the same line, to occupy a position still further off. Again, underground, such plants as the Iris or Solomon's seal act very much after the same fashion. A branch grows horizontally underground for a short distance, and then turns up into the air to produce its leaves and flowering stalks; another branch, starting from the buried part of the first, grows still farther forward, and also sends up leaves, etc. This "sympodial rhisome" method is very common. It will be seen that the principle is the same in the cases of the Male Fern, Sugar Cane and Rose Suckers, but in these the successive branches are formed at greater intervals, so that they do not form the distinct chain of branches, which is easily seen in Solomon's Seal and Iris. This underground colonisation is especially common in weeds.

The Canadian Thistle of American agriculturists, or "cursed thistle," has an extensive underground system of rhisomes and roots, which can produce buds at any point. Pieces of these underground stems only a quarter of an inch in length can reproduce the parent plant. As it is buried at a depth of 6 to 30 inches 
below the surface, it is well adapted to the conditions of agriculture. The uppermost parts catch in the teeth of the grubbers and harrows, and are actually spread abroad by the machines employed to eradicate them. The Autumn Crocus has an entirely different arrangement. The base of the stem swells out into a fleshy solid body (botanically a "corm") packed with a reserve supply of plant food. Flowering takes place on the strength of this food, which has been prepared the year before; after flowering, the leaves go on manufacturing sugar, and the rudiments of the new corm may be seen on one side of and a little below the old one, which is now becoming withered. Every year the new corm is formed in this way a little below and to one side of last year's, so that the roots exploit new ground every season. The plant therefore travels sideways and downwards, and eventually reaches a depth of 20 centimetres, after which it wanders horizontally without going any deeper. Even the Common Potato has an efficient system. The new tubers are formed on underground branches at some distance from the parent; there are many of these tubers arranged all round the original plant, so that, if all were allowed to develop as they liked, a circle of potato plants would be formed every year. Many other common weeds possess extremely perfect methods of spreading by branches or rhizomes, $\epsilon . g$. Ranunculus repens, Ranunculus ficaria (which has a quantity of very small potato-like tubers), Trifolium repens, and the Couch Grass, which last can form runners 10 to 16 feet in length.

In most of the cases mentioned, new and untouched parts of the soil are reached by a special branching or special direction of growth. But sometimes the plant 
itself moves from one place to another. The history of a Garlic bulb (Allium ursinum) is particularly interesting. The seed begins to develop on the surface of the earth, but as soon as germination begins the growing embryo becomes buried in the soil through a peculiar elongation of the stalk of the cotyledon, which carries plumule and radicle to a depth of 3-4 $\mathrm{mm}$. Its subsequent yearly history is as follows: In A pril a circle of peculiar fleshy roots is formed; they grow obliquely downwards, and, when they are firmly fixed by root hairs at their ends, they contract, losing about 30 per cent. of their original length; in so doing they draw the bulb downwards into the soil. From May to July the green leaves perform their work, and the flowers and fruit are formed. In September another series of roots grow, not downwards, but outwards; these are thin, they have no power of contraction, and simply absorb nourishment like those of ordinary plants. From November to April is the winter rest, and in April another circle of stout contracting roots is produced, which again drag the bulb downwards. Eventually it comes to lie at a depth of IO-I $5 \mathrm{~cm}$.

Dr. Rimbach has given many other examples of similar tugging roots, e.g. those of the Hyacinth, of the INartagon Lily, of the Snowflake (Leucojum), of the Strawberry, and of Hieracium Pilosella. The Dandelion always forms its leaves at about the level of the soil, because its thick fleshy root contracts every year just as much as is necessary. The Rat's Tail Plantain (Plantago major) has from forty to sixty roots each $30 \mathrm{~cm}$. long and I $\mathrm{mm}$. in diameter; these contract strongly, so as to pull the stem to about $5 \mathrm{~mm}$. below the surface. As the stem dies off below and grows every season at the apex, it is thus able to hold its ground 
exactly at the proper level. Ranunculus bulbosus, which has a little fleshy corm, behaves in a similar way, and is periodically hauled down by its contractile roots.

One of the most curious cases is that of the Raspberry. If a series of young plants are carefully pulled up, it will be found that the roots have thrown themselves into spiral coils; after the branch has reached the soil the rootlets fix themselves at the tip, and then, by their contraction, pull down the young shoot, coiling themselves like tendrils in the process.

It is especially in the loose, light, leaf-mould of woods that these subterranean colonisers are most abundant. The underground system of any of the following plants is well worth attentive study, as nothing can give so clear and definite a picture of the struggle that goes on for every cubic inch of fertile soil. Dog's Mercury (Mercurialis perennis) has a system of tough, horizontal runners which root and give off flowering stems at every node. As the internodes are from $3-10 \mathrm{~cm}$. long, and as perhaps twenty tough, slanting, anchoring roots trend downwards from every node, the whole system is very firmly attached, and may produce from I6-40 erect foliage-shoots on every square foot of ground. A single plant of the Wound wort (Stachys silvatica) may occupy a circle two feet in diameter and possess i 8-20 robust, leafy and flowering stems. The young creeping rhizomes, which end in the upright stalks, are, in both cases, beautifully adapted to insinuate themselves through the soil to a new ground; but, once established, the strong and closely set stems make it impossible for any other plant to grow beneath them. (Compare also the Woodsage (Teucrium Scorodonia)).

These subterranean rhizomes and roots being full of 
valuable food material have to be preserved from the attacks of animals of all kinds. Primitive man must have been one of the most dangerous enemies of plants; and besides the attacks of man, plants suffered from the depredations of boars, rats, mice, and other animals that lived on the stored-up food, and against these it was necessary to protect themselves. The rhizome of the Male Fern is said to have been in severe winters the chief article of food for the half-wild pigs in the New Forest. Hence the wiry roots and dry, withered leaf stalks which cover it as well as the remarkable secretion (p. 274). The valuable food stores of the Potato, of Wake Robin (Arum maculañum), and of the Cassava (Manihot utilissimus) are protected by bitter and even poisonous secretions (from .OI 2 per cent. to .042 per cent. of prussic acid occurs in the bitter variety of the last named), whilst the "Orris Root" of perfumery, which is the rhizome of Iris florentina, and Ginger (also a rhizome) have characteristic essences which probably are a little too strong and highly flavoured for the tastes of their enemies. The Anemone rhizomes, on the other hand, do not look in the least like anything edible, and may thus escape notice.

Plants with underground stores of food such as bulbs, cornis, etc., are particularly abundant in hot dry climates such as South Africa, from which country very many of our most beautiful bulbous plants are obtained. In Great Britain many of them are only conspicuous in spring; in late summer they have already finished their vegetation for the year and all their parts above ground have withered away. This is generally quite necessary because the grasses or the dense foliage of tall herbaceous species would certainly suffocate such compact, short clumps as those of Ranunculus ficaria or the long, 
weak, and broad leaves of the Garlic. This does not apply to those British Orchids which have underground stores, for they generally flourish in wet and rather barren places and only rarely in dry, rank grass.

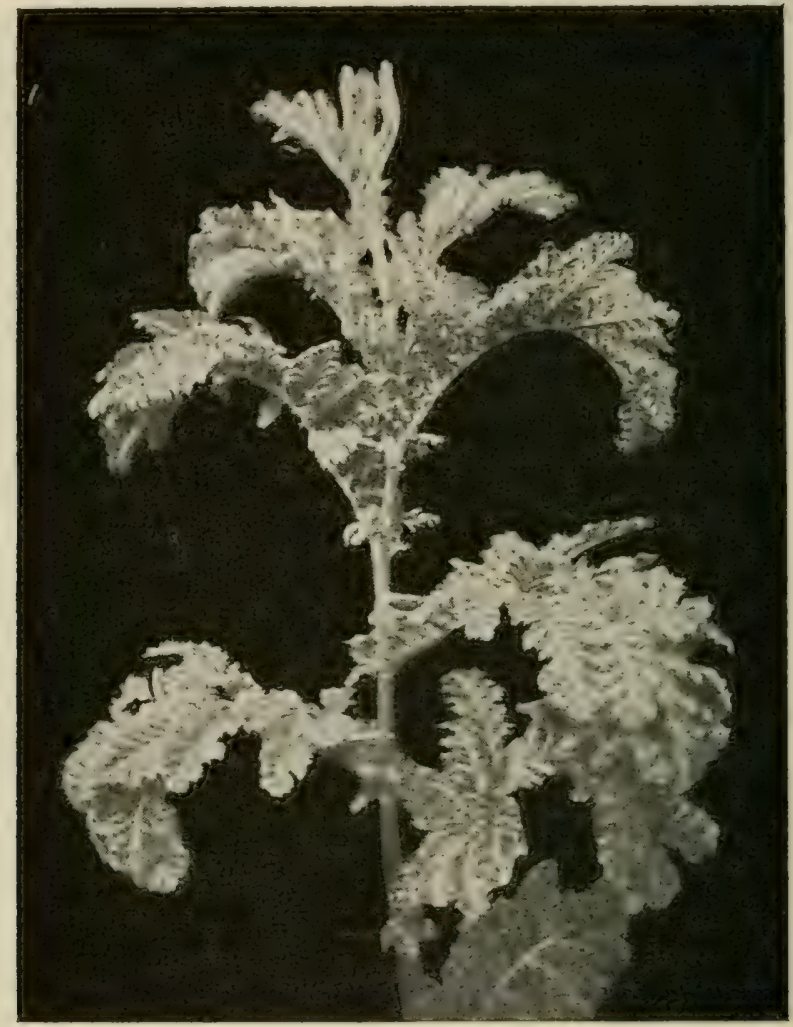

Fig. 7.-TANsy (Tanncetum vulgare L.). An autumn flowering herbaceous plant. It shows the gradual unfolding and the erect bud position of the leaves which are also finely divided.

The fact that bulls and corms are specially abundant in dry climates makes it probable that dry heat exercises some influence. Certain experiments have also shown that heat actually increases the yield in weight of potatoes.

These stores of food are certainly a great advantage to the plants which produce them. In South Africa 
they enable them to utilise to the full, any chance shower of rain, and in Britain to flower very early in the season when the ground is bare of other plants. The natural tendency to store up food has of course been greatly modified by man, as one can readily see by comparing a wild carrot with the cultivated form. He has stimulated and developed a natural tendency and in so doing has to some extent altered the character of the plant itself. If, for instance, Helianthus tuberosus is prevented from forming stem tubers, then unusual fleshy swellings appear upon the roots or elsewhere.

Thus the arrangements for colonisation possessed by plants are often of a very unexpected nature. Exact details of the ground over which they can spread in one year are unfortunately very difficult to find. In the American Tumbleweeds, in which the root or flowerstalk is torn out, the entire plant or its fruiting peduncle forms a sort of spherical ball of branches and stems (sometimes ten inches in diameter); this may be driven fifteen miles by a single hurricane. These Tumbleweeds, such as Salsola Kali, Corispermum, Hordeum jubatum, Bromus sterilis, etc., have been very thoroughly studied in America where the absence of hedges and trees permits of a very wide distribution. But in Britain the distribution cannot be nearly as rapid except under very exceptional circumstances. Still, if a grain of wheat can be blown fifteen yards in a minute by a strong wind, it is clear that it is not possible to give any exact limit to the possible distribution of plants by these methods.

It is only necessary for a student to attempt to dig up a complete plant of the Bishop's Weed (Aegopodium podagraria) to realise, both the complexity of its system of underground rhizomes and roots, and also the very 
neat way in which it is so arranged that a gardener's spade will just miss the oldest and strongest parts. The chief use of such plants in nature was probably to quickly colonise and cover over the bare earth caused by landslips or the washing away of river banks. Now a large number are of great importance in agriculture. 


\section{CHAPTER IV.}

SEEDLINGS, FOODSTORES AND GERMINATION.

THE appearance of the embryo or germ within the seed varies greatly. In many dicotyledons, it resembles a miniature plant consisting of a tiny root (radicle), two flat seedleaves (cotyledons) packed full of starchy or oily matter with a minute stem bud (plumule) between them. The seeds of the Almond or the fruit of the Ash will show the embryo very clearly if they are allowed to soak in water for fourteen days, and are then carefully cut open with a sharp penknife. But in many cases the seed is almost entirely occupied by starchy or oily food material; the embryo is very small and its parts are exceedingly difficult to make out.

To understand the structure of these embryos, it is necessary to know something of the internal structure of plants and this internal structure can be studied only with the aid of a microscope.

All plants are formed of minute "cells" which contain the living matter, "protoplasm," or "life slime," as it is called in some German works. The word "cell" is derived from the cells of the honeycomb which, as Nehemiah Grew showed, have when full of honey a very distinct resemblance to plant tissues. But the slimy matter in plant cells is alive. This transparent jelly-like material is moreover the only living substance. All animal bodies are made up of protoplasmic cells. 
The life, or consciousness of life, which we possess, is some sort of resultant of the lives of these cells. If we could imagine a city or a nation to have a real life of its own then we should have a good comparison for the life of a plant. The city or nation occupies its ground and does its work year after year, though the individuals which compose it are always being born, growing up and dying. So in the plant each cell has its own work to do and its own part to fulfil; its death in no way interferes with the existence of the plant; in fact very often it is the corpse only of the cell which is useful.

The development of the cell is wholly governed by the conditions in which it has been placed. Its individual life is entirely subordinated to the welfare of the whole community. One cell may die, and become a fibre or string which gives support and strength to its neighbours; another may become a piece of cork, or be used to hold a crystal; others again are kept alive for perhaps fifty years and used to form new cells, but they have no choice in the matter. They must become what is most required at that point. Yet there is a continual struggle going on amongst them. Just as one Orange embryo in a seed grows faster and devours all the others, so the cells in any part of a plant are competing for food with one another. Whether they have a community of feeling and mutual understanding or not is doubtful. There is no proved nervous system in plants, and an answer to this question must depend rather on the scientific imagination of the student than upon his power of reasoning from actual facts. It is however the case (as Gardiner has shown) that live cells in a plant are often or always in connection with one another by tiny minute threads of living matter, and, except as 
a sort of nervous union, it is difficult to explain these connections.

The protoplasm of a plant cell is poisoned by many of those substances which are fatal to man. Cells may be chloroformed or killed by ether or by alcolool. Yeast cells are rather stimulated than otherwise by a slight proportion of alcohol, but the presence of from IO-I 5 per cent. of alcohol in the solution kills them. Every cell also has to breathe in order to keep alive: it takes in oxygen and gives out carbonic acid gas. It has the power of secreting or forming materials of the most diverse kinds from the fluid in which it lives; it is in fact by this secretion of substances with the qualities desired for any particular purpose that most of the lifework of the cell is fulfilled. The feeding of a plant cell is, however, carried on in quite a different way to that of an animal, though the actual material of vegetableprotoplasm does not differ from that in the animal body. The protoplasm always consists of carbon, hydrogen, oxygen, nitrogen, sulphur, and often also of phosphorus. It is impossible to give a chemical formula for protoplasm, because it cannot be analysed without killing it, and when dead, it is no longer protoplasm. The necessities of life for a vegetable may be roughly summed up as follows :

I. It breathes (takes in oxygen and gives out carbonic acid).

2. It absorbs water and, dissolved in the water, nitrogen, sulphur and phosphorus which it requires for its protoplasm. Other minerals of great importance are also absorbed in the water.

3. It obtains carbonic acid gas from the atmosphere.

4. It obtains energy from the sunlight.

5. It requires mechanical support. 
6. It has to defend itself against the weather (physical conditions) and against vegetable and animal enemies.

\section{It has to reproduce or multiply.}

The special work of the leaf is carbon-assimilation and the supply of energy ( 3 and 4 ); that of the root is absorption of water and minerals from the soil (2); the flower, fruit and colonising arrangements are intended for reproduction (7). Every cell, however, has to carry on respiration (I), support itself (5), and protect itself from its enemies (6). The stem is chiefly for mechanical support. It is under stems also that the food and water distribution are most easily studied.

Every cell also has to obtain water (from the root) and its carbonic food material (from the leaves). Almost every plant cell consists of a small quantity of protoplasm enclosed in a wall which is built up round itself by the protoplasm. The wall, consists, at first, of a substance, "cellulose," which is secreted by the protoplasm, and which contains only carbon, hydrogen and oxygen. Within the protoplasm is a mysterious body, the mucleus, that appears to act as the manager of every process that goes on within the cell. A few Algae and Fungi are free and independent, but in all other plants the cells are joined together to make up the plant-body. By this union the cells become dependent on one another, and lose the chance of developing their own individuality, but it is only by the division of the necessary labours amongst them, that it has been possible for complex plants, such as Wheat, Orchids, and forest trees, to come into existence.

Every plant begins life as a single cell produced by the union of the male pollen grain with the female egg cell, and it is by the division of the egg cell that the seedling is formed. 
In such seeds as those of the Anemone and Orchids, the original egg cell has only divided a very few times when the seed falls to the ground for the winter resting period. In the case of Beans, Almonds and Nuts, on the other hand, the embryo has devoured all the starchy or other food material and entirely occupies the seed.

The embryo of an Anemone or of Wheat may therefore be compared to a squirrel which retires for the winter with a store of nuts, whilst that of the Bean is more like a bear which has grown fat in autumn, and which is contented with the food within itself.

If we examine, under a microscope, sections of ripe seeds we see that they consist of an outer hard coat of protective cells (the testa), surrounding the embryo, and the food of the embryo. The food material varies greatly in different seeds. Generally it consists of two distinct sorts of substances: Proteids, containing nitrogen and sulphur as well as carbon, hydrogen and oxygen, and carbohydrates, composed only of the three last mentioned substances.

In the wheat grain all four parts are clearly distinguished. The hard protecting skin which covers the seed is made up of the carpels and seed-coat; the cells are generally very indistinct, having become hardened and confluent. At one end of the grain is the embryo which has a single seed-leaf applied to the food matter behind it, as well as a minute root or roots and a stem bud. Under the microscope the body of the grain is seen to consist of elongated cells with numerous starch grains; round these latter and next the skin are square-shaped cells which are full of proteids and amides, that is, of those more complez bodies which contain nitrogen (aleurone grains). 
In other cases, proteids and carbohydrates are not separated, and both occur in the same cell. Starch is the most common of all the carbohydrates. It differs from sugar, which is supposed to be the first carbohydrate formed in the leaf, in its containing less water. - $\left(\mathrm{C}_{6} \mathrm{H}_{12} \mathrm{O}_{6}\right)$ sugar, and $\left(\mathrm{C}_{6} \mathrm{H}_{10} \mathrm{O}_{5}\right)$ starch.-The ripening of the grain in the ear is, in fact, essentially a drying process. The sugar travels to the grain and is there converted by the protoplasm into starch. In spring, when the seed germinates, this starch again becomes sugar, and as such travels through the plant to any point where it is required. The grains of starch are solid bodies formed of a series of shells one outside the other, and varying very greatly in shape and size. They are secreted by the living protoplasm, of which part is generally specialised for the purpose. Even in the structure of these grains we find proof that living matter is not able to go on working indefinitely. The shells above described correspond to periods of rest and of working quite similar to the waking and sleeping of animal life.

In the Date and Vegetable-ivory seeds we find, instead of starch, cell-wall substance; the cell-walls of every cell are very thick and hard, and are changed back into sugar in spring. In this case the hardness, which is a very marked character of both Vegetable-ivory and the Date "stone," is clearly protective ; and the young Palm, which may be noticed as a tiny white delicate body halfway down the seed, is guarded against injury by its own food. As these food reserves occur also in stems, rhizomes, bulls, etc., these may for convenience be mentioned here. Cane sugar is found in the Sugar Cane stem, the root of the Beet, and the young stems of certain Palms. The trunk of the Canadian Maple also contains a quantity of sugar, which is 
especially abundant in spring just before the leaves appear. At that season from I to $4 \mathrm{lbs}$. of sugar can be obtained from each tree. Grape sugar is unusual in food reserves, but occurs in bulbs. Roots of Dahlias and other Compositae contain a peculiar substance, "imulin." Fats and oils are very common in seeds; Rape-seed, Linseed, Castor oil, Cotton-seed, Palm oil, etc., being perhaps the most important kinds.

One substance found in stem shoots may be here mentioned, namely, asparagin, which is the chief ingredient of young, asparagus shoots.

Seeds are protected against their enemies in various ways. The Lufa or Loofah commonly sold in shops has an extraordinary arrangement, probably intended to protect the seeds. The fruit is originally similar to that of the cucumber; but the fleshy matter has been removed, and the veins or water vessels, which were used to carry food material to the seeds, have become tough, wiry strings, which form a sort of entanglement protecting the seeds within. The three carpels can generally be quite easily distinguished.

One of the most curious methods of protecting the seeds is that of the Cyclamen; when the capsule is ripe and full of seeds a peculiar coiling up of the flower stalk begins. It turns downwards and becomes spirally coiled; after a time the capsule is found to have been actually buried in the earth at a short distance from the parent. The Cyclamen, therefore, sows its seeds itself. The Creeping Jenny (Linaria cymbalaria) also hides its seeds in crannies of the walls, where they ultimately take root and grow.

These, however, are exceptional cases. The common methods of safeguarding the seed are as follow: (I) by means of hard woody shells, (2) by poisons or bitter 
secretions of some kind, (3) by mimicry, (4) by spiny projections.

The Date, as has been already stated, is protected by the stony character of its own food, and the seed-coat proper is of a very thin, papery character. Generally speaking, it is the seed-coat itself which becomes either stony or very tough. Sometimes the cells which compose it are very well worth examination under the microscope. They have a shape like the keystone of a bridge and are exceedingly thick-walled.

But any part of the fruit or seed may become hard and dry (see p. 4I); the "stone" of the plum and cherry is the "endocarp" or lining of the carpel, and so also is the "parchment" of the Coffee berry. In the Hazel nut and Acorn, and in the small dry fruits of the Buttercup, the entire carpel becomes hard and stony. It is worth noting that the development of the teeth of the squirrel, to take an example of a seed-eating animal, and that of the hardness of the shell, seem to have progressed side by side. A squirrel does not crack the shell without a little trouble, and no doubt the nut is growing thicker and the squirrel's jaws stronger every year. One of the most extraordinary fruits is the Brazil nut. The seeds are each surrounded by a stony seed-coat and form the ordinary "nuts," but the fruit which contains these seeds is dry and has a very hard woody shell, so that the food material is doubly protected.

It is possible to measure degrees of hardness by comparison with standard substances, such as quartz, flint, calcite, etc. This is done by observing whether the surface can be scratched by one or other of these bodies of standard hardness. By experiment on these lines, it has been shown (Ott) that the seeds of Celtis and the shell of Pinus Pinea are as hard as Calcite, the 
curious glossy shell produced by the enlarged bract of Job's Tears (Coix lachryma) is as hard as opal, and the shell (carpel) of Lithospermum is of the same degree of hardness as Fluorite. More observations on this subject would be interesting.

The pressure which seeds are able to support without breaking is sometimes astonishingly great. The following were the results obtained by the writer. The tests were carried out by means of a Salter's Spring balance. The seeds or fruits were placed upon it between glass slides and pressure exerted until they cracked; only cases in which the moment of breaking could be distinctly perceived were allowed to count. The first column shows the number of each kind which were tested, the second the lowest, and the third column the highest weight, which was found to produce breaking. The last column gives the average breaking weight. 


$+\ldots$

\begin{tabular}{|c|c|c|c|}
\hline $\begin{array}{l}\text { Number } \\
\text { of seed, } \\
\text { etc., } \\
\text { tried. }\end{array}$ & $\begin{array}{l}\text { Minimum } \\
\text { for } \\
\text { breaking } \\
\text { in lbs. }\end{array}$ & $\begin{array}{l}\text { Maximum } \\
\text { for } \\
\text { breaking } \\
\text { in lbs. }\end{array}$ & $\begin{array}{l}\text { Average } \\
\text { breaking } \\
\text { weight in } \\
\text { lbs. }\end{array}$ \\
\hline 50 & I & 3.25 & 2. 16 \\
\hline 50 & $3 \cdot 75$ & 6.5 & 4.88 \\
\hline 50 & & 2.25 & 1.635 \\
\hline 23 & 8 & I 5 & 7.09 \\
\hline 50 & I I & 27 & 19.04 \\
\hline 10 & I. 5 & 2.5 & 2. I \\
\hline 50 & 4 & 10.5 & 7.485 \\
\hline 12 & 26 & 46 & 32.08 \\
\hline 50 & IO & 19.5 & $14 \cdot 33$ \\
\hline 15 & 3.5 & 6.5 & 4.88 \\
\hline 10 & 24 & 50 & 33.6 \\
\hline 5 & I 2 & I5 & I 3.2 \\
\hline 7 & I 8 & 44 & 30.857 \\
\hline $3 I$ & I6 & 50 & 32.6 \\
\hline 20 & .5 & 2.5 & I.075 \\
\hline 8 & 4 & IO & $7 \cdot 25$ \\
\hline 14 & .5 & .875 & .64 \\
\hline $2 I$ & I & 4 & I. 98 \\
\hline 50 & 2 & 7 & $4 \cdot 34$ \\
\hline 50 & 4 & 8 & 6.4 \\
\hline I 5 & 8 & I 5 & I I. 93 \\
\hline I7 & 9 & 24 & I 7.84 \\
\hline 19 & 16 & 29 & 23.63 \\
\hline 5 & 25 & 30 & 27.9 \\
\hline I 4 & 2.75 & 4.75 & $3 \cdot 34$ \\
\hline 47 & 1.75 & 5.25 & 3.72 \\
\hline 3 & 13 & 20 & 16 \\
\hline 3 & 20.5 & 26 & 22.83 \\
\hline 3 & 10.5 & 14 & I I. 83 \\
\hline I6 & 8 & 14 & 11.16 \\
\hline 50 & 3 & 6.5 & 4.575 \\
\hline 50 & 2 & 6 & 3.62 \\
\hline 50 & .5 & 2.75 & 1.65 \\
\hline 25 & 2 & $4 \cdot 5$ & 3.18 \\
\hline 50 & I 2 & 30 & 20.42 \\
\hline 50 & IO & 26 & 17.19 \\
\hline
\end{tabular}


SEEDLINGS, FOODSTORES AND GERMINATION. 8 I

In a very few cases only, the amount supported was less than one pound. Amongst these may be mentioned :

Glaucium phoeniceum, - seeds |about $.75 \mathrm{lbs}$.

Nigella hispanica, - - " $\quad, \quad .5$ lbs.

Fumaria officinalis, - nut $\quad "$ I lb. to $1.75 \mathrm{lbs}$.

Stachys silvatica, - - nutlets \# I lb. to $\mathrm{r} .25 \mathrm{lbs}$.

The most interesting results were obtained in a few cases tested by a Wickstead machine.

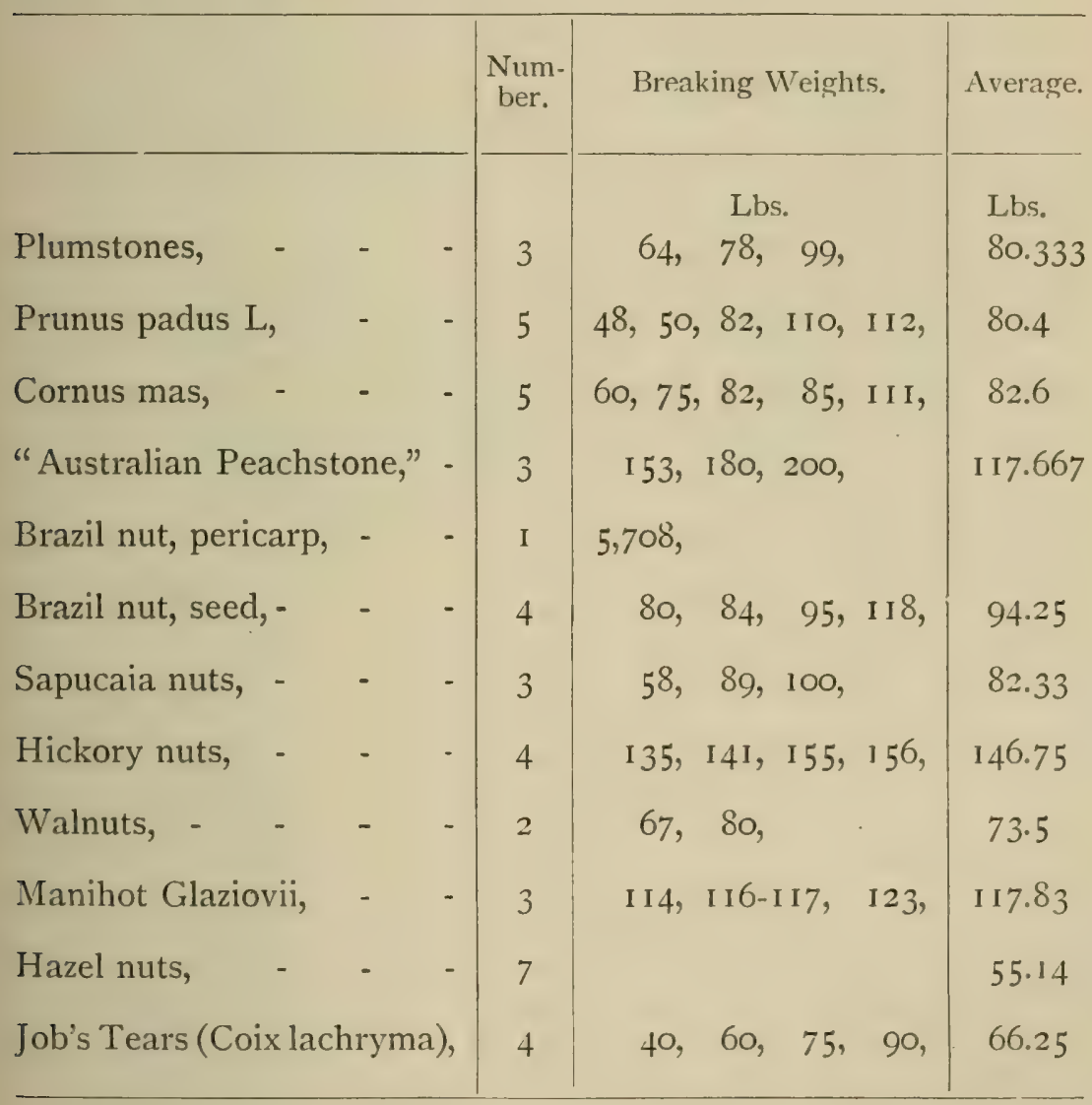

It is only with some hesitation that the results of an experiment with the fruit of a Brazil nut are given. (B 7) 
The pressure at which it broke, 5,708 lbs., was much more than was anticipated. The test was kindly carried out for me by Professor Longbottom, to whose kindness I am indebted for the use of his machine, while I watched the fruit carefully and waited anxiously for the result. Faint sounds of cracking were heard even at I,500 lbs., but these were simply the superficial ridges yielding; there was not the slightest distortion until the enormous weight of $5,708 \mathrm{lbs}$. was employed when the nut cracked with a report like that of a pistol shot.

Very often the food-stores of the Embryo are protected by bulbs or poisonous secretions. Most ordinary drugs are obtained from Rhizomes, Seeds, Roots, etc., which contain food material for the young plant. The deadly poisons of Strophanthus and Nux vomica are found in the seeds. The seeds of both are so peculiar in appearance that it is probable that animals learn to avoid them. Strophanthus, in addition to the poison (Strophanthin), has a very hard woody envelope formed of the carpel wall which protects the young seeds. In one species there is a curious covering of woolly fringes which is probably intended to keep off insects. The Calabar Bean, Crab's Eyes or Jequirity and other poisonous seeds are also very conspicuously and distinctly coloured. Tropaeolum seeds are doubly protected, both by the bitter taste and by their very peculiar wrinkled appearance, which probably resembles particles of the ordinary soil in which they would be found. The following are typical examples of medicinal or poisonous food-stores: Scilla or Squills (bulbs), Aconite (tubers), Turmeric (rhizomes) and Ipecacuanha (roots).

Mimicry is an even more unusual mode of protecting the food-stores, but it has been suggested as an 
explanation of some peculiar resemblances. Most seeds are very difficult to detect when they are in the ground; for they are very commonly of the shape and colour of particles of the soil or of small stones. The fruits which do not open and are dispersed by any of the ordinary methods often resemble seeds; the fruits of the common buttercup and the strawberry carpels are e.g. very like seeds. The dry fruit of one of the Compositae, Calendula officinalis, resembles the larva of an

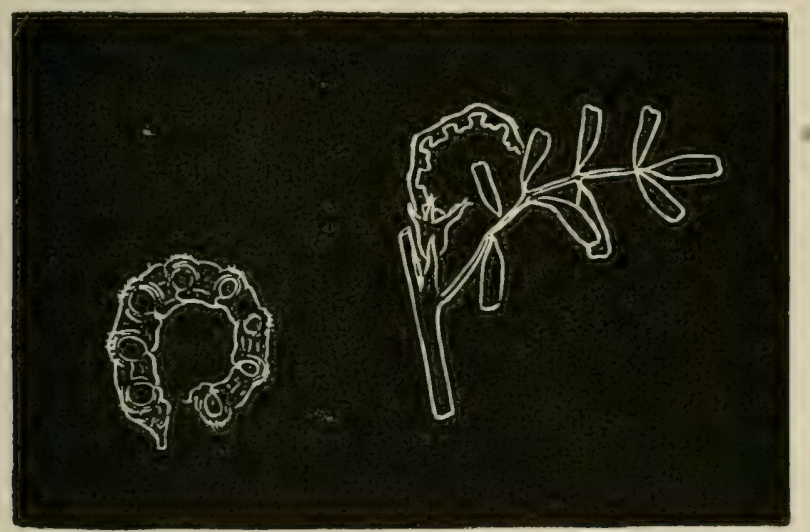

FIG. 8.-Hippocrepis $s p$. The pod resembles a caterpillair.

insect Curculio. Some weeds have seeds resembling very closely grains of corn. Sometimes this resemblance is due to a family relationship, as in the case of several Avenas ( $A$. fatua, $A$. sterilis, etc.), which are very like the Oat. But in other cases the resemblance cannot be thus explained. Probably, though it is difficult to prove, the resemblance has arisen from those which were most like corn having been unconsciously preserved by man.

Other more extraordinary cases of resemblance are the pods of certain Leguminosae which are extremely like caterpillars. The Castor-oil seed is again rather like a 
small beetle, and this has been supposed to keep birds from touching it. Pigeons, however, are exceedingly fond of the seeds, and do not appear to object either to the spines upon the fruit, the strong medicinal properties, or the beetle-like appearance. In Africa, wherever there are castor-oil plants in fruit, these birds are almost certain to be discovered feeding upon them. Some fruits again are extremely like small dead branches, as for example, those of the Willow-herb and many which are produced from an inferior ovary. Many of the thin long pods of Cruciferae are also liable to be overlooked as they are very similar to branches, especially when young.

Everyone must have noticed the spines on the Beech cupule, edible Chestnut, and Horse Chestnut fruit, before the latter opens. These are, of course, intended to protect the fruit in its young condition, and they only open to allow the nuts or seeds to escape. Similar spiny protections are by no means unusual.

The seed, which has to last through the winter, is made as compact, hard, and dry as possible ; and often shows a very extraordinary tenacity of life. Wheat, after being dried in vacuo, has been heated to $100^{\circ} \mathrm{C}$. ( 2 I $2^{\circ} \mathrm{F}$.) without its being rendered incapable of germination. The seeds of vegetable-marrow, mustard, barley, and pea, germinated after enduring a cold of $-453^{\circ}$ Fahrenheit (Dewar). The seeds of Oat and Fennel germinated although they were exposed for I I 8 days to a temperature of $-40^{\circ} \mathrm{F}$. The seed of Thespesia populnea was not injured by being kept for a year and a half in a dry place and in water for another year.

It has been stated that Mimosa seeds germinated after a delay of 60 years; R. Brown also found that seeds 
of Nelumbium more than IOO years old were able to develop normally. It is even said (Nature, Vol. LV., I 896, p. 2I), that seeds from plants buried under rubbish heaps collected by the Greeks have developed and produced flowers, but one would like more evidence before accepting the possibility of their having retained life for I 500 years in a dry condition. During the dormant period seeds are of course alive and breathe. A kilogramme of seeds will in fact give off from 0.33 to $2000 \mathrm{mg}$. per hour. The amount varies with the moisture of the atmosphere.

The two essentials for the germination of seeds are warmth and moisture. The embryo plant sucks in moisture and swells, bursting its seed coats; its cells secrete a liquid ferment which acts upon the starches and other matters, changing them into sugar; this last enters the seedling as fast as it is formed by the ferment, and the embryo-plant soon appears above the surface, and its ordinary leaves turn green and expand.

The way in which the seedlings develop shows much variation. At this early stage of their existence the plants are exposed to many dangers, and a very large proportion of the seedlings are exterminated. Hence, in many cases, much of the early development is carried on below ground, and out of sight.

In the Bean the two first seed leaves nearly fill the seed, only leaving place for a very minute stem bud or "plumule" between them and a short curved "radicle" or young root along their edges. The two seed leaves never make their way out of the seed coat, but their food materials are digested whilst they are still enclosed in it. The stem and root grow outwards, but it is only after the latter is fairly long 
and well able to absorb food that the young stem makes its first appearance above ground. This type of germination is also found in most Grasses and in the Oak.

The Date seedling has a very remarkable history. The part to develop is the stalk of the seed leaf; this grows so quickly that the stem and root, which are attached to the end of it, are carried down below the surface where they develop into working roots and a young stem : the rest of the cotyledon remains in touch with the hard food-material inside the seed which lies upon the surface of the soil ; thus the cotyledon carries all the stored-up food down to the buried embryo. This burial of the young plant is probably a protection against the scorching heat on the sand.

In most cases the seed-leaves escape from the seed coat; and, after a time, turn green and assist in the ordinary leaf-work of forming sugar. Thus, in Cress seeds the part which forms and grows first is the root and the small piece of stem below the cotyledons. The root soon buries itself in the soil, whilst the tips of the cotyledons are still held in the seed coat; after a short time they tear themselves away and the stem, which was previously bent down, straightens itself, and the two seed leaves open and spread out. The Cucumber seedling tears off the seed coat by a special notch on its stem. The Beech, most Cruciferae, the Maple, and the Sycamore are in most respects similar to the Cress.

Very often the first appearance of the seedling above ground is in the shape of an arch or $n$. The root is fixed in the ground and the tips of the seedling cotyledons are also below ground, being retained by the seed coat. The arch does not force its way straight up 
through the soil, but curves slightly from side to side; therefore the soil particles are more easily displaced and slip over it.

These seed leaves or cotyledons are, generally speaking, more simple in structure than mature leaves. In the case of some Arctic Saxifrages, this original cotyledon shape is retained by all the leaves, probably on account of the severe conditions preventing any further development. But in most cases the cotyledons, either because they have to be packed in the seed, or because they are filled with food materials, show little variation and no particular adaptations to resist their enemies. Hence the great destruction of plants at this period of life.

As Lubbock has described all the important types, a further description of seedlings is not required. The growth of the young leaves and shoots of bulbs and rhizomes are much more interesting. Some of the commonest objects in early spring are well worth careful examination. For instance, the bracts and bracteoles of Snowdrops overlap at the tip and are connected by a thin white covering like oil paper; the two first leaves of the Daffodil are pressed together, and have in outline the shape of a lance head, so that they can when growing upwards pierce the soil or penetrate the foliage above them; the developing Lily of the Nile has also a very neat arrangement, but any bulbous plant is sure to be worth examination. The Dog's Mercury is particularly interesting, as the young stems are bent over so that they can more easily grow up through mosses and dead leaves. Each leaf is rolled at its edge in such a manner that the rather square and tough midrib protects it. All the leaves and the stipules fit together in such a way that they form a sort of conical surface attached 
at its narrow end to the stem. Hence rain and soil particles slip down over them, and cannot injure the delicate tissue within.

Many of these young developing leaves show a characteristic slimy or gummy secretion. This is particularly distinct in the young dock or sorrel. The internodes are at first very short, and the young leaf, which has the thin green parts neatly rolled up on either side of the midrib, is enclosed in the stipulesheath; it is also very slimy, and the exposed parts are often red. Both this colour and the mucilage are protective; probably the slimy or mucilaginous matter prevents loss of water whilst the leaf is young, and at the same time also prevents any harm arising from its being rubbed, whilst still delicate, against the stiff edges of the sheath. Other cases which show (according to Dr. Hunger) the same mucilaginous oiling of the young parts to prevent injury by friction are the young leaves of Ranunculus ficaria, Viola silvestris, and Chenopodium Bomes-Henricus.

Every sort of protection is required in early spring ; because, if the weather is too dry, germination cannot take place, whilst, if it is too wet, there are hundreds of fungus spores ready to attack the young leaves before they have had time to form their hard protecting skins. Such fungi as Pythium de Baryanum may destroy whole beds of seedlings, or Phytophora omnivora may attack the cotyledons of young beeches and destroy every plant in a nursery. It is important to remember that every plant in such a complex system as a Grass meadow has to suit not only its adult but also its scedling environment.

For mankind these food stores are, of course, absolutely necessary. The amount yielded by different 


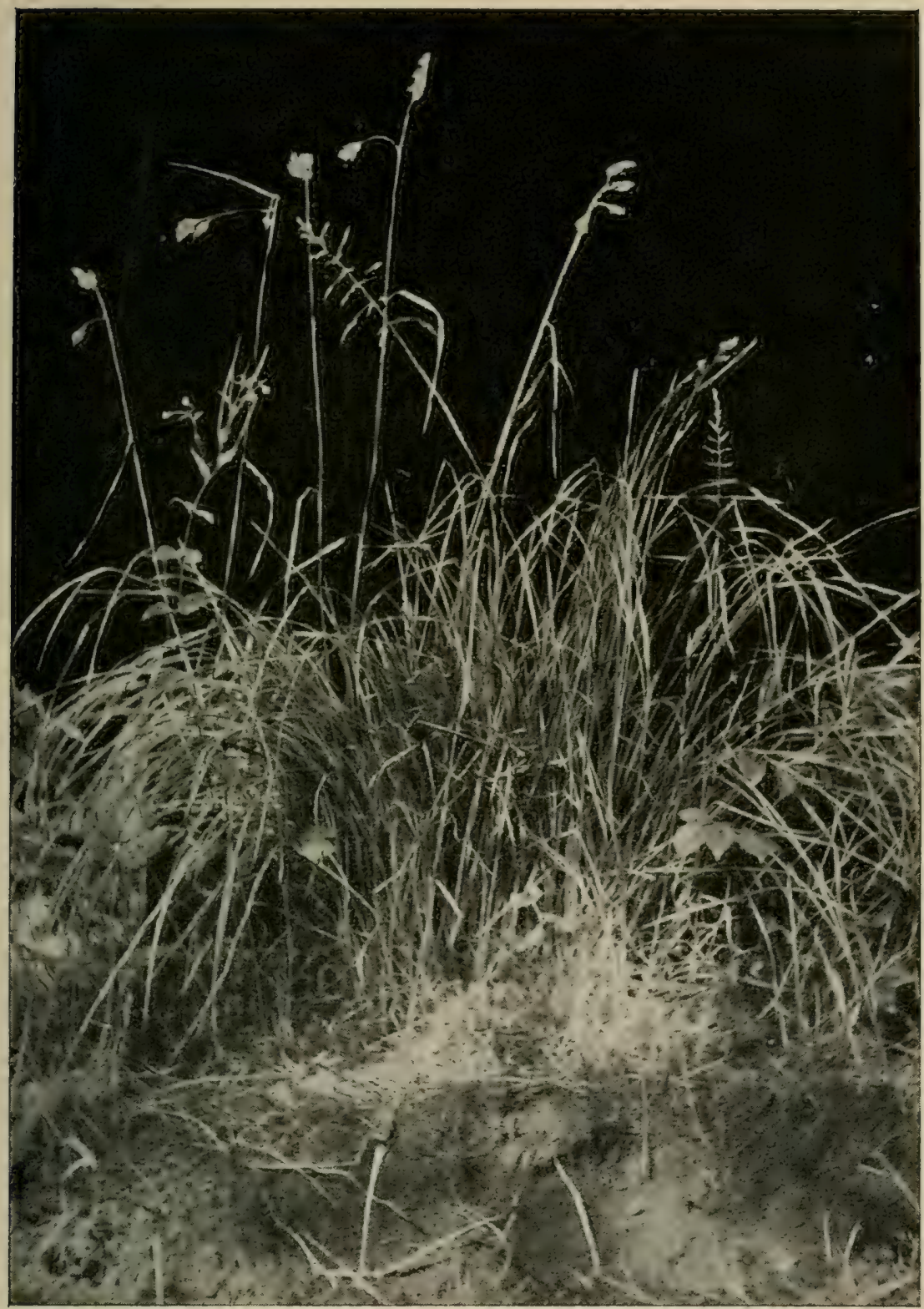

Fig. 9.-Section of Vegetation, chiefly Grasses rartly shaded by TrFes. The tall grasses Cocksfoot and Poa trivialis, with Yorkshire Fog to the right, form tufts between which the leaves of Bishopsweed (right) and a plant of Willow-herb (left) have insinuated themselves. Some of the rhizomes and roots in the soil can be seen, but they do not come out well against the earth colour. 
plants varies very greatly, as is shown by the following estimate :

$\begin{array}{lcrcc}\text { Sago palm, - } & 292,320 \text { lbs. of food per acre. } \\ \text { Banana, - } & - & 242,000 & " & " \\ \text { Potato, - } & - & 4,000 & " & " \\ \text { Wheat, - } & 2,000 & " & " \\ \text { Manioc (Cassava), } & 6,650 & " & "\end{array}$

Nothing is so persistently forgotten as the dependence of mankind upon these food reserves stored up by Grasses, Potatoes and a few other plants for the use of their embryos and young buds. Even botany is of less importance than the cultivation of the soil, and the strongest claim of the science upon mankind depends upon the possibility of its being occasionally a useful handmaid to agriculture.

For Great Britain particularly, a knowledge of the amount of possible harvest for every acre of the country, and of the amount of foreign-grown corn annually imported should be within the reach of every enquirer. Sir William Crooke's address to the British Association in 1898 , is perhaps the single broad and complete attempt to analyse the sources and available extent of food for civilised man.

In this address it is very clearly shown that the land capable of economical cultivation is limited in amount, whilst bread-eating peoples are increasing every year without any limit at all. Thus the danger is perfectly obvious, and is sure to manifest itself in an acute shape within a short period.

On a broader view, taking into account the whole food supply of the world (that is Bananas, Sago, Potatoes, all the Cereals and other valuable plants), it is clear that the area which can be devoted to their production is 
enormous; the larger part of at least two continents, Africa and South America, is still mostly covered by primaeval forests; and in these two continents, also, the population is insufficient. Thus, although India (295,000,000 population), China $(383,000,000)$ and most of Europe is far too crowded to grow much food for export, yet there is a large balance of unoccupied land able to yield food of some sort. The subjection of the earth by man is therefore still decidedly incomplete. 


\section{CHAPTER V.}

\section{DEFENCE.}

Although, as described in the previous chapter, there are many dangers in the seedling stage of existence, plants continue to require protection during their whole life, and must be prepared for all sorts of emergencies.

Rain, hail, wind, snow, sunshine, and especially drought are very dangerous, and have to be provided against. The competition with other plants for water, soil, and sunshine, is excessively severe. There are too, whole series of animal and other enemies. In fact, the entire animal world lives, either directly or indirectly, upon vegetation. Every species of plant therefore must protect itself from browsing animals and injurious insects. There are also vegetable fiends such as the Mildews, the Rust fungi, and Germs which beset the developing plant at every stage of its life, and at every part of its body, and against whose attacks it must provide.

A list of the enemies of any one particular plant, say the Apple, will give a more distinct idea of these dangers to which plants are exposed, and of the thoroughgoing modifications which these have brought about in vegetable structure. First, as regards the stem, there is under the bark and next the wood a delicate layer of living and growing tissue known as "cambinm." This cambinm is the favourite food of certain beetles which make their burrows within it. 
The eggs are laid along the hole which the mother insect forms by devouring the tissue. The grubs from these eggs eat out burrows for themselves which extend at right angles or sideways to the original path made by the mother. This system of burrows has a curious resemblance to a spinal column with diverging ribs. To keep out these creatures, and for other important reasons, the stem is covered with a thick coating of cork. The smaller branches of the apple are the favourite habitat of the American Blight, a small insect of the nature of a "Green Fly," which lives by sucking the juices of the young and tender twigs. These latter require therefore a strong skin, or an epidermis with hairs or some other form of protection.

The leaves of the apple are subject to the attacks of all sorts of enemies. Caterpillars, such as those of the Winter and Great Winter Moth, devour the leaves bodily, and may easily destroy a whole orchard, especially considering the fact that a single one of these insects may lay 400 eggs. The buds also are very eagerly sought for by insects on account of the sugar and other nutritious matters which they contain. The "Applesucker" lays its eggs about September upon the fine hairs of the twigs; in the spring, exactly at the time when the buds are ready a small flat grub appears which insinuates itself between the budscales, and once inside devours all the younger tissues. The "Appleweevil" also attacks the buds in spring; it bores a little hole through the scales, and lays one egg in each bud. The larva developed from this egg remains all the spring within the bud sucking apple-sugar, and will, of course, destroy it altogether. After boring its way out, the insect seems to wander about during the summer, living on the food material which it has 
accumulated, and finally passes the winter on the bark of the tree.

Even when the apple has escaped these enemies, and is nearly ripe, it is still exposed to the ravages of the Codlin Moth, a little grey inconspicuous insect that lays an egg in the centre of the withered flower, which happens to be just the weak spot of this particular fruit. A caterpillar developed from this egg eats down the style to the core: it devours the seeds, and then eats its way out through the flesh. After reaching the outside, it lets itself down from the tree by means of a silk thread, and hides itself in the bark or in any other convenient shelter. It then becomes a chrysalis, and emerges next spring as a fully developed Codlin Mioth. One of these moths can infect 50 apples.

Nor are the roots free from enemies. The soil is inhabited by grubs of many kinds such as those of the Daddy-Longlegs, of the Cockchafer, and of the Wire Worm. Mice, rats, and roles also attack the roots of apple-trees as they do the roots of other sorts of plants.

The apple being a cultivated plant is protected from many of the enemies which attack wild species. Roedeer, cattle, sheep, rabbits and hares, often tear or nibble off the bark or leaves. In hard winters, rabbits will attack the bark of almost every shrub except perhaps the Snowberry (Symphoricarpus) and the common Rhododendron. Wild boars root up and devour all fleshy roots and bulbs. The goat and camel are also particularly destructive to vegetation, and are supposed to have totally altered the character of the vegetation in Egypt and other places.

So far no mention has been made of the fungi, but each species of plant has its own particular fungus enemy. Cultivated plants whose constitu- 
tions have been weakened, by their being placed outside the vulgar struggle for existence which is incessantly continued in Nature, often suffer from the attacks of an extraordinary number of these fungi. As the Vine has been perhaps better studied than almost any other plant, it may be interesting to give a list of its special fungus enemies; most of them are not found on any other species.

(I) The root is attacked by a fungus, Pourridie or Weinstockfaule (Dematophora necatrix). The absorbing threads or "mycelium" grow through the soil to attack the roots of neighbouring plants; they destroy the soft tissues, and especially the fibrous rootlets.

(2) Upon the leaves any of the following fungi may be discovered: The "downy" or "false mildew" (Plasmopara viticola), which belongs to the potatodisease group, and produces whitish patches on the underside of the leaf; Uredo vitis forming spots on the upper surface, and belonging to the Rust-fungi; Colletotrichum ampelinum forming small dry spots on the leaf surface, sometimes shrivelling up the whole leaf ; Cercospora viticola also a leaf-spot form ; the "Brunissure" (Plasmodiophora vitis), one of the slime fungi (see below), which lives inside the soft tissue of the leaf, forming light brown star-shaped spots, and causing a premature leaf-shed; Sphacrella vitis chiefly on withering leaves.

(3) The following occur on the young shoots, and sometimes on the leaves and fruit: "Black-rot" Laestadic Bidruellii, Gloeosporium ampelophagum (also called "Black-rot" and not certainly distinct from the preceding), and the "White-rot" (Coniothyrium diplodiella).

(4) The green bark is subject to the dreaded 
"Anthracnose," or "Bird's-eye Rot," and to Phoma ampelinum, which produces sunken pits in the bark with a raised shrivelled margin, and kills the tissues.

(5) Even the tendrils have a special enemy, Leptosphaeria vitigena.

(6) Amongst the best known diseases of the grape are "Vine Mildew" (Uncinula spiralis), of which the fruit is a brown spherical body surrounded by curious hooked anchoring appendages, which cling to the young leaves or fruit; the spores germinate in wet weather and destroy part of the fruit; the grape then bursts because the healthy parts continue to grow. Another is the Sclerotinia disease, which is also found on the fruit. Moreover, if grapes are injured at any time by the bruising of their delicate down or skin, many mould fungi may gain an entrance to the sugary juice, and entirely destroy it. (Notably Penicillium glaucum and Botrytis.)

(7) The "Mal Nero" which causes the wood of the Vine to decay, is due probably to a Bacterium. The I 6 or I 7 fungi mentioned here by no means form a complete list of the enemies of the Vine. (See Tuboeuf.) The spores of these fungi are carried by the wind, or sometimes by bees when they are visiting flowers, and are probably present in enormous numbers when the disease is once established.

But it will be seen that every part of the plantleaf, fruit, twigs, stem and root, has its fungus enemies, which are always ready to attack any organ that is at all weakened or defective; when any fungus has been able to multiply unduly, it is even able to attack sound and healthy plants, and the existence of the species may be endangered. That, however, 
is probably a very rare phenomenon with plants in a state of Nature.

The defensive armour of plants is generally adapted to resist many different evils. The more important general protections are the following:

(I) Cork and the other outside or "skin" protections.

(2) Latex, or milky juice containing indiarubber or caoutchouc.

(3) Resins, such as Turpentine, etc.

(4) Tannins.

(5) Acids, Alkaloids and other bodies with strong medicinal properties, including vegetable poisons.

(6) Scents.-Strong-smelling ethereal oils, such as Lavender and Mint.

\section{(7) Crystals.}

The more special defensive weapons are:

(8) Thorns, Spines, and Prickles.

(9) Stinging Hairs.

(10) Ants of a fierce disposition which keep off leaf-cutting insects.

OUtside Protections.- - That part of the plant, which is on the outside, is always covered by a special skin, which is intended to guard against fungus and insect enemies, and which also prevents the evaporation of the water or sap which fills the tissues. Vegetable cells always contain a very large proportion of water when alive, and they are dependent upon it for their nourishment; hence it is very necessary that the water should not escape unless it is intended that it should do so. (See p. IOO.) The character of the skin varies; young parts are generally covered by the original epidermis. The older branches and trunks of the Pines and Dicotyledons are almost always covered (B 7) 
by cork, which is produced by a special layer of corkforming cells. This "cork cambium" appears very soon in the life of a branch; sometimes the epidermis itself (Willow), or it may be the cells of the cortex (Elder), or even cells much deeper within the stem (called the

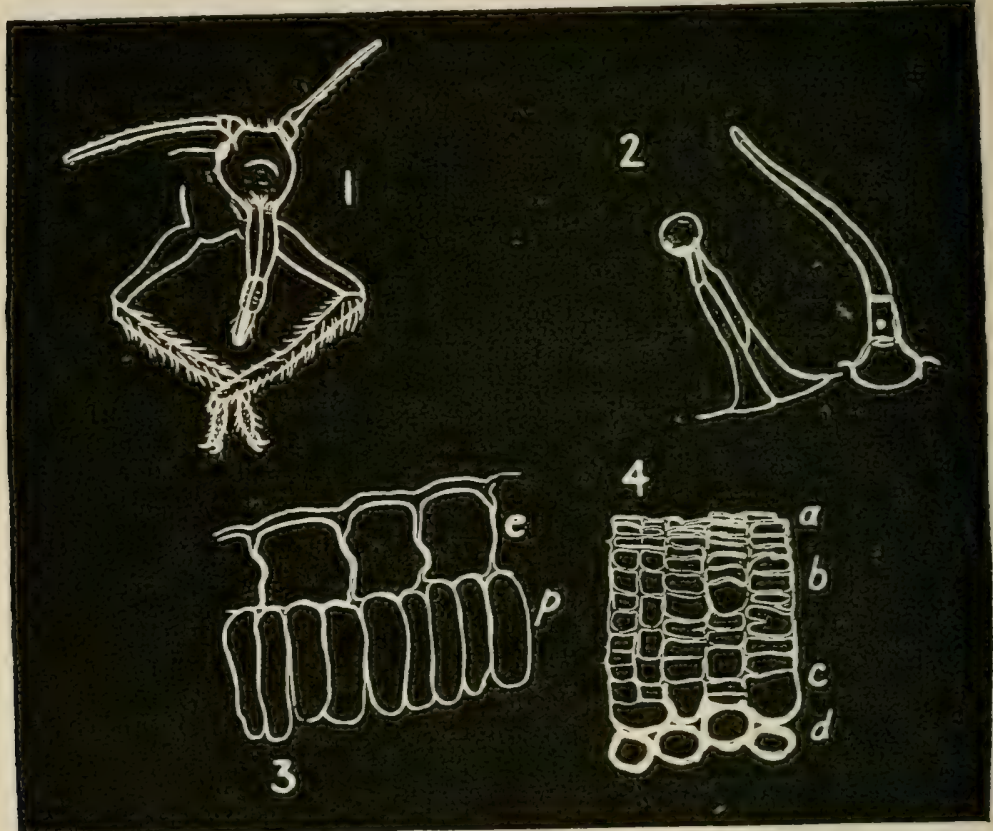

FIG. IO.-DEFENCE. (I) Head of a green fly showing proboscis with central probe, legs with sharp claws and part of antennae (on leaves of Acer pseudoplatanus). (2) Glandular and other hairs of Shortea californica. (3) Epidermis of Acer pseudoplatanus; $(e)$ cells of epidermis, $(p)$ pallisade cells. (4) Cork of Walnut; $(a)$ outer disorganised and (b) typical cork cells, (c) cork-cambium and (d) strengthening (collenchyma) cells below the cork.

"pericycle") suddenly change themselves into a corkproducing cambium; they then divide rapidly, and in a very regular manner, so as to show the very even, homogeneous, and continuous appearance which is characteristic of cork. As soon as this cork-sheath is formed, all the epidermis and other cells outside it at once die away, because their food and moisture is intercepted. Cork is very impervious to water and 
air ; it is also antiseptic and elastic; so it is very well adapted to keep in water, to keep out air, and to prevent insects or fungi from entering into the stem, where they might do great harm. The elasticity allows it to yield when the branches are swayed or distorted by wind, and within certain limits to adapt itself to the increase in thickness of the stem; but, generally, the cork-cambium goes on forming new cork, and the older parts of the sheath crack or scale off. Sometimes the old dead cork scales off in strings or irregular flakes, but in most trees it remains in the shape of irregular ridges, which differ in pattern according to the age and species of the tree. The importance of the sheath can be judged from the way in which a potato, when peeled or stripped of cork, loses in weight; about 64 per cent. of its weight will be lost through the evaporation of water in 24 hours.

A hailstorm may do an infinite amount of damage to plantations by breaking through the cork-sheath, and so enabling fungi and insects to enter; yet the plant has arranged for accidents of this nature. For instance, if a small twig is torn off a tree, or, if any accident produces a wound deep enough to reach the woody part, the plant at once begins to cover the injured place. The walls of the broken wood vessels become changed into gummy matter of which a drop seals up the aperture of every open vessel. At the same time the living bark cells set about making a new cork-cambium. This begins all round the wound, and is formed by cells which are quite uninjured. Thus the injury is soon surrounded by a basin of cork, which, as growth goes on, swells inwards forming a sort of wave of corky matter which gradually closes in over the wound, and eventually covers it. But if the wound is very large, 
the closing does not generally take place fast enough to prevent infection by fungi; and a tree so wounded is often attacked by these enemies, and even sometimes killed. Leaves are able to protect themselves by a sort of amputation of the wounded parts as has been shown by Dr. Blackman. If short slits are cut in the leaf with scissors, a layer of cork is formed a little way back from the injured cells, and a cork border is produced all round the injury. The scars left by fallen leaves are also always corked over; the coating is formed before the leaf actually falls, and a special layer of very thin cells is formed in the stalk above the cork layer, so that the leaf comes neatly and easily away. The ordinary cork of commerce is the result of a process of artificially stripping the trunks of the Cork Oak of their natural covering. The tree in response produces a very thick and homogeneous cork layer, which is the commercial produce. It should be also noted that cork is used by man to keep in liquids and prevent fungi and insects from entering. The Mediterranean countries produce annually I 000 metric tons of Cork chiefly from France (Algeria), Portugal and Spain.

In the younger parts of the tree, it is necessary that the water should sometimes escape. A continual loss of water or transpiration goes on even from leafless branches during winter. Leaves and very young twigs are continually giving off water. Thus both the epidermis and the cork sheath, though covering the entire outside of the plant, require special valves by which this water may be allowed to escape under due restrictions. These openings are the stomata in the epidermis and the lenticels of the cork. Stomata and lenticels are automatic valves which allow the water to escape and the air to enter, but only in a regular and 
prescribed way. They are shut or open according to the degree of tightness or expansion of the watery tissues below them. When this is full of moisture they open, but close when it becomes dried through the escape of water. The lenticels are small, rough, lip-like protuberances easily seen on the twigs of most trees.

LATEX.-Another defensive arrangement is found in the Latex or Milly juice, which occurs in the rind or cortex of many plants, though unfortunately it is by no means common. This Latex is a complex mixture of indiarubber, guttapercha, resins, oils, proteids, and occasionally starch. It occurs in long branching tubes or cells which run up and down the plant, especially in the bark or cortex of the stem, though the tubes are also found in other parts. The substance is very elastic. It is very resistant to fungi, and is also waterproof. It generally contains bitter substances, often of a very poisonous nature; thus opium, laudanum, and morphia are made from the latex of the poppy. The milky juice of the tree Euphorbias found in East Africa, is said to produce blindness if it touches the eyes, and certainly raises painful blisters on the skin. These rubber-bearing trees are especially common in Brazil, along the Amazon and its tributaries. In this region, there are many wood-boring insects which eat through the bark, and, of course, are apt to injure the trees. If such a beetle is met by a gush of milky latex, it will certainly either be overwhelmed and destroyed, or at any rate it will be unable to continue its attack. As the rubber coagulates and forms a sort of rubber-stopper over any wound in the bark, it must be a valuable protection against such enemies.

Mr. Belt in his Naturalist in Nicaragua mentions that trees which had been drained of their latex by too 
severe cutting for rubber were riddled by the burrows of these beetles. This defensive use of latex has been recently questioned by Mr. Parkin, but there can be no doubt that it does protect the tree from beetles, though, of course, it may be of use in other ways. Many in. valuable products, among them Atlantic cables, bicycles, golfballs, waterproofs, etc., depend on rubber or guttapercha, so that the supply of latex is of great importance. The low-lying moist forests of Brazil send to Britain about 200,000 cwt. per annum. The West Coast of A frica, the Malay Peninsula, and British India are other important sources of supply. The world's supply of rubber has been valued at $£$ I 5,000,000 annually.

RESINS.-Resins and Turpentines are abundantly formed by Pines and other Coniferous trees in northern latitudes, and are exactly of the same use to these plants as the latex is to the plants of the tropical jungles. On examining a cross section of a Pine Stem, the resin-canals in the bark are very conspicuous. They are lined by small cells which secrete the resin; the canal is not a cell, but an enlarged opening between the cells or an intercellular space. If the tree is wounded in any way, the white resin appears and solidifies on the surface. It follows that the grub of the Giant-sawfly, of the Carpenter-bee, or Goat-moth, is not likely to succeed in an attack upon trees which are full of this substance. Resin is a complex body which yields on distillation tar, turpentine, and other substances. From the tar, pitch and essence of turpentine are formed. The resin industry is a very important one. Some three million acres are covered by resin forests in the one district of Velsk in Russia. The resin trees are allowed to grow for from 60 to 80 years, and are then stripped regularly of bark for five years, when they are 
cut down. Tar, pitch, resin, and turpentine are of course extremely valuable products, and appear to have been used by man since a very early period. A whole series of substances secreted by plants, and akin in character to resin might be mentioned here. Probably all are secreted or excreted to defend the plant either from animal enemies or from the danger of losing too much water when accidentally wounded. Thus there are the true Gums, such as Gum Arabic, which is produced by various Acacias found in Upper Egypt, and was an article of Egyptian commerce in very remote times. Another kind of gum can be easily found on Cherry branches which have been broken or injured. Amongst other similar substances are the true resins such as Copal and Grass-tree-gum; Inodorous Gumresins such as Gamboge; Odorous Gum-resins such as Myrrh, Bdellium, and Opopanax; the Oleoresins such as Lacquer and Turpentine, etc.; True Balsams such as Balsam of Peru; and Volatile Oils such as Camphor, Menthol, Spirits of Turpentine, etc. (see below, p. IO5). These are used by man, sometimes merely as strong perfumes, but more often as insecticides, preservatives, or for varnish, i.e. for protecting substances from the attacks of insects or bacteria. Some of them are as characteristic of dry climates, as the Pine is of northern latitudes, and the latex of tropical jungles.

TANnins.-Another group, the Tannins, is very widely distributed in the bark of trees. Tannin gives the peculiar astringent taste to most barks, and is, almost certainly, used for defence against bacteria and small insects. Man employs this tannin for rendering the leather of boots and shoes impregnable to bacteria. A little more than one per cent. of tannin is sufficient to destroy the growth of bacteria and fungi. Oak 
bark in spring contains from 4-20 per cent., whilst Australian Wattle has 20-36 per cent. of tannin. Gall nuts are often rich in such secretions. This is specially interesting; for it is clear that, after the insect has punctured the bark, the cells all round the place must be stimulated to pour out an excessive amount of the tannin, with the view of resisting its attack. A regular commerce is carried on in the wooden Oakapple-like galls of Quercus infectoria, simply because of their rich tannin contents.

Acids And ALkaloids. - A very large series of Acids and Alkaloids (which will undoubtedly keep off dangerous enemies of some kind) are produced by plants. Amongst the best known of these are Nicotine, Quinine, and Theine. They occur dissolved in the cell-sap, or as amorphous bodies inside the cells (often in connection with the tannin), and appear to be generally manufactured in the leaves; a single leaf may form about .00005 gramme of quinine alkaloid every day. The quinine of the Cinchona is a poison to the malaria-germ, which lives in human blood corpuscles, but we have no knowledge of the particular enemy which attacks the tree in a wild state. A great many of these alkaloids are very deadly poisons, and, in the early stages of human history, the desire of men to avail themselves of this property in their struggles with their enemies, must have been a great incentive to the study of plants. The use of arrow-poison must especially have been a very great advantage. It seems to have been very widely used by the more helpless races of mankind, and it is still largely employed by savage and semi-savage races in all parts of the world. These poisons are found in every part of the plant; in the seeds, as in Strychnos nux-vomica, Strophanthus, Laburnum, etc.; in fruits, 
as in the Deadly Night-shade; in the leaves, as in Foxglove; in the bark, as in Sassy-bark, the bark of the Erythrophleum guineense, or ordeal tree of West Africa, in the Roots or Rhizomes, as in Monkshood or Aconite.

Most of these poisonous plants are remarkable in colour or shape, as is obvious, if one calls to mind the conspicuous lurid purple of Aconite flowers, and the berries of Solanum Nigrum, or the very extraordinary shape of the seeds of Strophanthus and Strychnos; and it is quite probable that the larger and more intelligent animals recognise their dangerous character and leave them alone. Such poisonous qualities also run in plant families. Among the British orders, the Solanaceae, Ranunculaceae (Buttercups), Liliaceae, and Amaryllidaceae, are exceedingly poisonous, whilst others, such as Cruciferae, are quite harmless.

SCENTS. - Another very marked characteristic which also seems to run in families, and is intended for defence, consists in the possession of strong perfumes or scents, such as are given off, for instance, by the foliage of Mints, Lavenders, and similar plants. Grazing animals are much more dainty in their tastes than is generally supposed. Horses will sometimes refuse hay without Sweet Vernal Grass, if they have been accustomed to the smell of the new-mown hay which is given off by it. Two common British Natural Orders, the Labiatae and Umbelliferae, are especially remarkable for possessing ethereal oils and perfumes of this kind. To the first belong Sage, Mint, Lavender, Thyme, Balm, Rosemary, Horehound, and Basil (all well-known spices or condiments), and also others, such as Woundwort (Stachys silvatica), which has a very powerful and objectionabie odour. The Umbelliferae include Myrrhis, Caraway, 
Coriander, Anise, Cumin, and Fennel; but in their case the scent is found chiefly in the fruits, its purpose probably being to keep birds from touching them. Some of these, as well as other scents, like that of Eucalyptus leaves, are used by man as bactericides, or to keep off insects ; others, like Cloves and Allspice, are employed as spices in food to stimulate the taste cells, which, when so stimulated, pour out a larger secretion, and thus make the taste more pronounced. In the plant, such spices are much too strong for a sucking or gnawing insect. Some of them are also exceedingly fatal to bacteria. The vapour of oil of cinnamon kills typhus bacteria in 45 minutes; oil of lavender, or that of Eucalyptus, are also fatal to germs.

Crystals. - The Sulphur, which is essential for the food of plants, generally enters them in the form of sulphate of lime. The Calcium, which is eventually set free, combines with oxalic acid, which is formed during the process of assimilation. As oxalic acid is poisonous, this has some importance, but the crystals produced are generally either like long fine needles, "rapliides," or are rounded bodies covered with hard sharp points. It has been shown (by Stahl) that these crystals prevent snails and slugs from devouring the tissues. Snails even when starved did not touch vegetable tissue full of raphides, but when these were dissolved by the use of Acetic acid they devoured them greedily. The raphides are very common in Monocotyledons. The stalk of the "Arum Lily" (Richardia Ethiopica) shows them very clearly.

THOR NS, ETC.-Against grazing and browsing animals Thorns, Spines, and Prickles are a much more conspicuous method of protection. Not much is known as to the way in which these are produced; but in dry climates 
it is often found that the tips of branches, or of leaves or leaf-teeth become dead, and remain as sharp spines or thorns, which are found exceedingly useful to the plant in keeping off the camel, the goat, or other grazing animal. Such thorns and spines are very abundant in open scrub-like country, such as the Karoo of Africa, and the deserts of Central Australia, where a grass, "Spinifex," prevents thousands of acres from being cultivated. It is in the deserts, the natural home of the camel, the horse, and the ass, that thorns are most abundant. Almost every plant in such regions is pro-

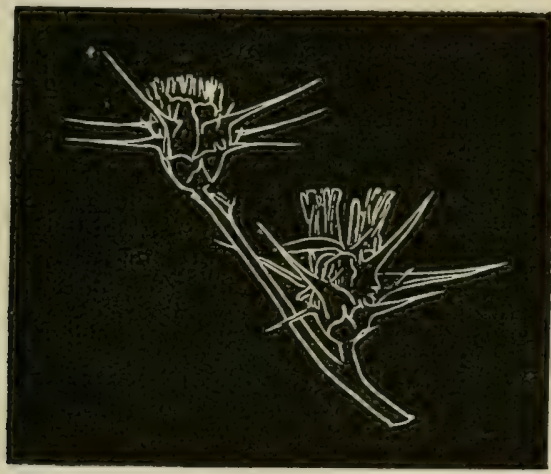

FIG. II.-Spines of the involucre bracts of Centaurea calcitrapa.

tected either by thorns or spines; or by strong balsams or poisonous secretions. Amongst the most curious examples are the following: Carlina acaulis, in which the little rosette of leaves lies absolutely flat on the sand, whilst in the centre, exactly in the position to pierce the nostrils of a grazing animal, there is a circle of sharp spines, each of which is from $I$ to 2 inches in length. Those of Centmurea calcitrapa are also modified bracts of the involucre. The Gum Tragacanth (Astragalus tragacanthus) has also a rosette of leaves which are pinnate, and consist of some 7-8 pairs of leaflets. These leaflets soon drop 
off, but the central mid-rib remains as a strong hard spine. These withered midrib-spines entirely cover and protect the leaflets on the younger leaves. The common Acacias of the desert have usually very long spines, which are formed from the stipules of the leaves; the same arrangement is found in False Acacia (Robinia), which is not uncommon in this country in shrubberies. They are, in this last case, small and curved, so that an animal must find it difficult to strip off the young leaves which appear from the bud just above. The Barberry has spines which are produced from a whole leaf; they protect the bunch of small tender leaves which develop just above them.

The thorns of the Sloe, Hawthorn and Whin are modified branches (the leaves in the last-mentioned case are also spiny). All these plants grow in positions where they are specially open to attack by grazing animals. The Bramble forms a thicket exceedingly difficult to penetrate because the strongly armed branches root at the tips. Both in the Bramble and in the Rose the prickles are neither leaves nor branches, but excrescences which are produced without any relation to the leaf. Both Rose and Bramble use their prickles, partly for defence and partly to assist them in climbing. Their long branches straggle over those of taller plants and hook themselves upon them. A very remarkable prickly form is a Wild Yam (Dioscorea prehensilis). The plant grows in the Taru Desert of East Africa where wild boars of a special kind occur. The plant is about $\mathrm{I}$ o feet in height and looks at first sight like an immense arbour covered by an intricate network of strongly prickled roots. In the centre there is a fleshy root-tuber full of food material. There are very few cases of spiny roots; but some Iridaceae and also certain Palms possess them. 
In the Common Holly, the leaf-teeth are spiny, and similar spines are found on the Evergreen Oak. It has been stated that, in both, the lower branches and those plants that have been especially cropped and pruned have much more spiny leaves than the higher branches, or specimens which have been allowed to grow freely. This would go to show that the injury done by grazing animals directly promotes the growth of prickles. But the fact is a little doubtful, though, as has been mentioned, it is obvious to any one who has ever seen a desert flora (e.g. that of the Sahara, of the Grecian Hills, or of Spain), that a dry or desert climate certainly seems to produce thorniness of one kind or another. Such climates always produce an open scrub-like vegetation, and are especially suitable for man, and for all grazing animals.

From the botanical side, it is seen that branches may become thorns; leaves may turn into spines (Barberry), or stipules (Acacia, Robinia), or the midrib of the leaf (Astragalus tragacanthus) may do so. Prickles also occur on the leaf, stem, and root. Two other cases may be given to complete the series. The Alpine Festuca has very sharp hard spiny-leaves, from which it often happens that the cattle which graze in Alpine pastures, where this plant grows, bleed severely from the nostrils. The Rotang palms, such as Desmoncus have their leaflets changed into long spines. These palms are climbers often of great length and are exceedingly tough and strong as well as abundantly thorny. The thickets formed by them are almost impenetrable to mankind.

The relation of thorns and spine to the strength and tceth of the grazing animal cannot be further considered here. It should of course cause no surprise, as the intimate connection between an animal and its food should lead to exactiy what we find does exist. 
Stinging Hairs such as we find in the Nettle and its allies are also important weapons of defence. The nettle has a partiality for waste places near human dwellings, and it would soon be trodden down were it not for its stinging hairs, and its habit of growing in dense clumps which are made up of many stems springing from an underground, much-branched root-stock, often eight feet or more in length. The leaves are quite wholesome, for they can be made into either tea or spinach; and they are especially good for poultry. String also can be made from the bark, a yellow dye from the roots, and oil can be obtained from the seeds. Yet the stinging hairs seem to protect it from everything except caterpillars and fungi. Some foreign nettles have much more poisonous stings. The Devil's Leaf (Urtica urentissima) stings so severely that its effects may be felt for twelve months; and the sting of a handsome Australian tree, Laportea moroides, may even kill horses.

Myruecophily.-The last and most interesting method of defence consists in the plant using some kind of insect as a species of police, or army, to keep off injurious insects or larger animals. These defenders are chiefly found in tropical countries where leaf-cutting ants which live in colonies and strip whole trees to form their nests are not unusual. The best known case is that of some South American Acacias. The plant has hollow thorns and upon the tips of its leaflets there are small projections which are full of sugary material. The hollow spines are inhabited by colonies of fierce soldier ants, which swarm out, and drive off any insect enemy, and are fed, or "boarded," on the food-bodies of the leaflets. In this country there are no leaf-cutters, and few soldier-ants, so that similar arrangements are not employed. Nevertheless honey is secreted by the 
stipules of Vicia sepinm and Vicia sativa, on the sepals of the Paeony and by special hairs on the young leaves of the Ash. It has not, however, yet been shown that they keep off any special insect enemy in Britain. The Bracken leaves, when young, have also many sugary hairs which are visited by ants; and, according to one observer, these keep off caterpillars from the young leaves. There are, however, in Britain "police" insects, which probably are of great importance to the leaves they inhabit. Almost any common tree, such as the Lime, Ash, Elm, or Horse-chestnut, will show on the lower side of the leaves little hairy patches which occupy the forks of the veins. If these are examined in summer with a strong magnifying glass, and stirred up with a pin, very small active insects or mites will be found. They run about quickly, and once seen, can be observed with ease, whenever looked for. The hairy grottoes which they inhabit, are often rather neatly formed; but they are difficult to describe. As a rule the colour of the insect is that of the hairs amongst which it lives. These mites come forth at night, and appear to live upon bacteria and upon the spores of fungi, lichens, or algae. But here again, it is not possible to give as exact details as would be desirable.

A very extraordinary case has been described recently, in which a plant and three kinds of insects are concerned. Quercus pubescens is subject to the galls of a little insect, Cynips argentea. These galls secrete nectar which attracts ants, and these latter keep off caterpillars and snails.

Some idea can be gathered from the preceding pages of the multifarious dangers to which plants are exposed. The "Green-fly" or Aplid family are perhaps the worst enemies. A single one of these creatures will in 
300 days produce by its own multiplication $2 \mathrm{IO}^{15}$ greenflies according to Buckton's computation. According to Huxley the Ioth brood of an Aphis would contain more animal matter than the population of China. These aphides are easily observed in the Sycamore. In dry seasons they multiply so rapidly upon it that the sugary secretion which they give off coats the leaves with a shiny varnish, and may even drip to the ground. This is the "Honey Dew," the "Sweat of Heaven" or "Saliva of the Stars" of Pliny, and others. Ants are fond of sucking their honey, and one (Lasius flavus) collects the eggs of these aphides and stores them, carrying food to them when young.

To kill them off Miss Ormerod recommends a Paraffin Naphthalene emulsion; a saturated solution of naphthalene in paraffin oil, combined with boiling soft soap. This should be used as a solution, I-I $\frac{1}{2}$ parts in 100 parts of water.

This chapter will have shown the number and importance of the defensive methods employed by plants; and it will also have shown how many invaluable products are obtained by man from them. Thus to give only two instances, the silk industry, worth annually $£ \mathrm{I} 8,000,000$, and tea plantations $(828,000$ acres in India and Ceylon) as well as imports of tea paying yearly to the Exchequer about $£_{4}, 000,000$ sterling, are sufficient to show the importance of plant defences to man. But the fact that the life histories of man, animals, insects, and plants are inextricably entangled with one another, is of the greatest importance to a right conception of Nature, and this is very seldom brought forward in botanical teaching. Such a case as the fungus Ophionectria coccinea, which is parasitic upon 
the plant louse (Parlatoria zizyphi) which latter is a parasite of Citrus trees is by no means uncommon. When examining a plant in the field a botanist is very apt to forget these multifarious enemies and complex dangers, and thereby misses the plain meaning of many details of its structure. 


\section{CHAPTER VI.}

\section{ROOTS AND THE SOIL.}

THE surface soil, in which the roots find water and substances in solution, constitutes but a very small proportion of the earth's crust. Generally it is exceedingly shallow; often only a few inches in depth; though, sometimes, roots do penetrate 20 feet or more. Yet the entire vegetable and animal world is supported by this mere film of altered and crumbled rock.

The supply of water to the root is of the greatest possible importance; if it is insufficient the whole character of the vegetation alters. Thus upon the Nile, above the first Cataract, the "Seyal" and other Acacias, with roots capable of penetrating to 20 or 30 feet, are almost the only plants able to retain their foliage. This and similar floras in South and East Africa are produced by the permanent water being from I6-20 feet below the surface, and too deep, therefore, for the roots of ordinary plants. Where subsoil water is absent, or lies at extreme depths, the result is such a desert as the Sahara.

It must be remembered that the water in the atmosphere, in the soil, and in the ocean, is almost always in motion. That which evaporates from the sea, or the earth, or plants, is promptly carried off by winds. It may be carried to a very great distance, before it meets a mountain range high enough to force the 
vapour-laden air to ascend to those colder levels of the atmosphere, in which it is obliged to condense on any convenient dust particle, and fall as rain. After the shower has fallen, most of the water sinks into the earth, though much of it is hurried off by streams to the sea. The sinking water eventually reaches some impervious layer, probably of clay, and there accumulates in underground lakes, or gently flowing streams. As soon as the surface begins to dry by the action of sun and wind, the water rises from this underground reserve, or subsoil water. If there are no plants on the soil above, it ascends, and is evaporated very quickly, so that drought soon begins to set in; but, if there are live plants of any kind, their root hairs fix themselves on the wet earth particles and absorb the moisture, which is eventually given back to the atmosphere by the leaves; only, however, after it has performed all the duty which the plant requires of it, and only just as rapidly as the live cells of the leaf choose to let it go.

The plant world is then a sort of temporary passage in the general water circulation of the globe.

Much of the surface drainage is hindered in its passage to the sea, and often absorbed by vegetable life. A wet rock is often covered by Algae, such as the dark purple Rivularia or by Liverwort cushions. Mosses and Lichens also are kept fresh and living by occasional showers. In any place where water tends to gather, marsh plants accumulate; sometimes they even delay the escape of water for a whole vegetation period. This is conspicuously the case in Uganda, where the Papyrus swamp is a sort of natural water reservoir, allowing tall grasses and even forests to flourish in the valleys, in spite of the nine months' drought. Forests on the hills in a dry country, such as India, have a most important 
effect on the climate, and for a similar reason. The springs and little streams are hindered in their escape, and shaded from evaporation. Even in our own country, draining the marshes of the hill pastures and moorland has had a distinct effect on the rivers. Periods of excessive spate, soon after rain, alternate with droughts, when the river usually falls very low.

The manner in which any kind of soil permits water to trickle through it, and the depth at which a layer of clay or other impervious soil exists, are, therefore, very important factors in determining the vegetation of the locality. The following experiment by Professor Wollny shows this influence of vegetation on erosion: one square metre of bare soil at a slope of $30^{\circ}$ lost 3 IO4 grammes, whereas grass-covered soil at the same slope only lost 50.8 grammes.

Soil may be roughly described as a skeleton or framework of stones or hard particles, generally more than three millimetres in diameter, between which there lies the finer earth. This latter consists chiefly of clay (alumina and silica), and fragments of decayed animal and vegetable matter. The clay is formed of the original rocks, because water, acidulated by carbonic and nitric acid, has dissolved and removed the other materials. Even the subsoil has been, in most cases, greatly altered by previous vegetations. The past history of sandstones, shales, alluvium, and especially of boulder clay, involves very great alteration by physical and biological factors; and their present constitution and value for plant life depends upon this.

As regards water, soils behave quite differently. Schwarz gives the following example:

A layer of soil Io centimetres deep will allow the 
following amounts of water (in cubic centimetres) to sink through it in 24 hours.

\begin{tabular}{c|c|c|c}
\hline Sand. & Loam. & Clay. & Peat. \\
\cline { 1 - 1 } 5,760 & I,674 & 0.7 & I \\
\hline
\end{tabular}

The amount of water in saturated soil is also very different according to its nature: IOO cubic centimetres of peat will contain $\$ 2$ grammes of water, of loam 43 , of sand 34 , and of clay $5 \mathrm{I}$. Then, again, if the particles of soil are more than 2-3 millimetres in diameter, it is not possible for water to rise by capillarity from below. Hence, on the clinkers of a railway track, for instance, the plants are reduced to what they can extract from the ground, so long as it is kept moist by rain, which, in such places, dries up very rapidly. Therefore the railway line will possess southern and dry-climate or sun-loving species, such as Linaria viscida and L. repens. Plants such as Tragopogon, and even Viola comuta, only find it possible to exist, in such wet and cold districts as Glasgow and Dumfriesshire, upon the railways. (See p. 334.)

Generally speaking, the finer the particles of soil the more easily water can be carried up to the thirsty roots. And, in fact, in clays and loams, the danger is often that the plant receives not too little but too much water. The soil will tend then to bear rushes and moss, and the more useful plants, whose roots object to water in excess, will become sickly and languish. This can often be seen in Glasgow in small garden plots or areas, where the grass will often die, forming a sodden and unsightly felt, on which a few green Algae begin 
to grow. On a very heavy clay soil potatoes can only be grown, if it is very deeply ploughed; and, in the same way, the steep clay bank of a railway cutting will occasionally produce in great abundance plants like Ladies' Fingers (Anthyllis vulneraria), and others, which are associated in one's mind with sandy and dry places. In the last case, the slope prevents the accumulation of water characteristic of clay soils, and it becomes very much drier. The ordinary farmer's terms, "cold" and "warm," depend on the same factor. If the soil allows water to trickle through readily, it is drier, and has a higher temperature than ground which is always wet, and evaporating water.

A character of equal importance is the amount of air channels in the earth by which oxygen can be obtained, both by the roots and by those animals which live amongst them. To keep the roots well supplied with oxygen, and to allow it to work on decaying matter, is, in fact, exactly the office which these creatures perform. The difference between leaf mould, which is extraordinarily fertile, and peat, which is exceedingly barren in its natural state, is largely due to the activity of worms and other animals. These, by burrowing in the soil, ensure a perpetual supply of oxygen to the decaying vegetable matter, which then becomes available for the roots. Otherwise, in wet places peat will be formed; or, in dry and exposed woods, a blackish brown peat-like mass, on which Blaeberry and Heather begin to grow. In both cases the process of breaking up or decomposing the decaying vegetable matter is hindered, and the absence of worms is one of the most important causes.

The water contains in solution practically everything which is found in the soil. Of the minerals, only a 
few are absolutely essential to plant life. The most important are: Nitrates, Sulphates, Phosphates, and Salts of Potassium, Soda, Lime, Iron, Magnesium, Manganese, Chlorine, and Silica. The first three are essential, as they are essential parts of the living matter protoplasm. The others are utilised in the chemical changes that go on within the plant: lime, for instance, is taken in, in the form of calcium sulphate (see p. 106); iron has something to do with the formation of green chlorophyll; and potash is of great importance in the process of assimilation. Certain kinds of plants make special demands in the way of certain minerals : thus Potatoes and Turnips prefer potash; Cereals require much silica; and Leguminosae take in a large proportion of lime. It is upon this fact that the advantage of a rotation of crops depends.

As the roots are intended to exploit this mineral water in the soil, it is only natural to expect that they should exhibit in every detail of structure, and in their method of development, an exact adaptation to their duty.

Their method of growth shows this distinctly, for the main root, in most cases, works towards the centre of the earth, yet not in a straight line, for it often revolves with the tip moving in a circle or ellipse, so that it is able to take advantage of any convenient crack or crevice, e.g. a worm burrow. The side branches go off horizontally, and their branchlets go off both directly upwards, and downwards. Thus every year the sphere of influence is extended and new ground is broken. A very old comparison of the root system to a river is absolutely correct: the branchlets of the root correspond to the mountain streams; the tree trunk or stem to the main river; and the leafy branches to the 
delta at its mouth. ${ }^{1}$ No two plants, however, have exactly the same method of root formation. Thus, amongst our common trees a long main root is characteristic of the Oak, Ash, Edible Chestnut, and Lime tree, whilst others have very wide horizontally spreading root branches, like the Spruce, Birch, and probably the Douglas Fir, and are therefore more liable to be uprooted by the wind.

Besides this power of growing in a definite direction, roots are very sensitive to both moisture and light. They seek out moist places in the soil and bury themselves in the dark so far as possible. During their exploration in the soil their tips are protected by little thimbles of dead tissue, the root-caps, which save the delicate growing tissue from accidental injury. They can push small obstacles aside; if they meet a stone which they cannot thrust away, a message is sent back to the growing part; this latter begins to curve to one side, and the young root will, probably, circumvent the stone, and proceed upon its way. Only the extreme tip of the root is thus sensitive. If in the course of thus bending aside, the growing part, not the tip, is brought against the stone then the reverse happens. The growing part bends round the obstacle and presses itself against it. These two properties supplement and assist one another, so that a root can find its way down any irregular passage, or crevice.

It has already been stated that, in the case of common trees, every species has the desire to form its root system in a particular manner; but this is often

${ }^{1}$ The same comparison, reversed, applies to the supply of food material by the sieve tubes. The leaves are the laboratories, and their supply is collected into the phloem of the stem and eventually distributed, in a delta-like manner, to the rootlets. 
modified by differences in the soil. It is also modified in accordance with the nature of its continual struggle for existence underground. Within limits, the rootsystem can be varied to suit the varying conditions of soil and moisture. In loose, light, and easily-moved sand, it is sometimes extraordinarily long and greatly branched. Nettles in light organic soil, near human divellings, may be over seven or eight feet. The little Honckenya peploides, of which some six inches only is usually visible above the sea sand, may have underground stems and roots 9-I 2 feet long, and if covered over, it can grow upwards through a thickness of I 2 inches of soil.

On the other hand, in dense, hard-packed earth, the root system is bushy and compact. The Wild Radish can be forced to form a round or globular root in heavy, close soil, and an elongated one in loose and light earth.

With these inherited tendencies and varied powers of adaptation, it is clear that roots are well able to reach the ascending films of water. The manner in which they work can be easily understood from their anatomical structure.

As seen in the cross or transverse section (and represented diagrammatically), the cells are arranged somewhat as follows:

First, on the outside are the absorbing root hairs, of which there may be as many as 230 or even 400 on a square millimetre of the surface. These can exercise some force during their growth and push aside particles of earth; they can also adapt themselves to the shape of the earth particles, often appearing to surround or enclose them. Next comes a broad belt of roundish, not specially remarkable, cells, the cortex of 
which the innermost layer differs from the rest. This innermost layer of closely-set cells, "endodermis," forms a cylinder which divides the cortex from the inner water-conducting part. Very often a peculiar dot may be noticed on the radial walls of these cells (see figure) which is a ring of cork. It appears as a dot in the transverse section but as a line in the tangential section. Each of these endodermis cells is, in fact,

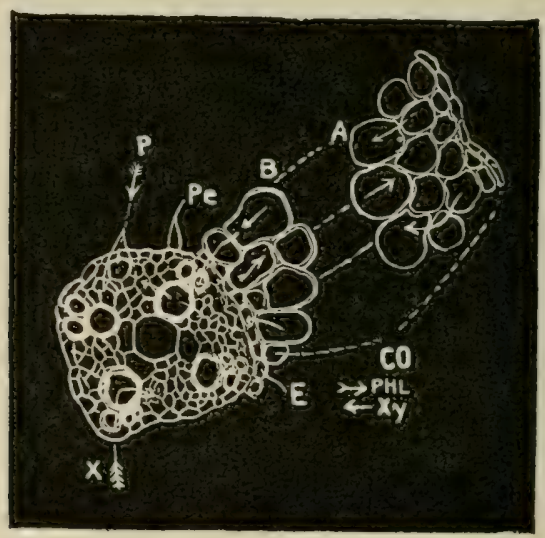

Fig. 12.-Transverse Section of Root (Ranunculus repens). The xylem is formed of four groups of vessels $X$ which will eventually be united by the change of the connecting cells into a central 4 -spoked cross. The barbless arrows $x y$ show the path of water entering from the cortex. Phloem, $P$, is not in contact with the xylem. $P e$. Pericycle or rootlet- and cork-forming layer. E. Endodermis with a dot on radial walls (cork). Co. Cortex, only a small part of which is shown. The one-barbed arrow PHL shows the path of the food material brought by the supply pipes of Phloem (three-barbed arrow at $P$ ). The fourbarbed arrow is the main water pipe through $X$ passing up the stem.

separated from its neighbours by a piece of cork, which is placed between them, or all round each cell. The reason for this arrangement is given below. The central or conducting system of the root contains three distinct kinds of cells. (I) Unmodified or not yet specialised cells. (2) Water-conducting vessels, or tracheids, the "Xylem." (3) Food-conducting tubes and cells, the "Phloem."

In old roots the xylem is often arranged in 
the shape of a chariot-wheel, or it may be in a single line across the centre; sometimes it resembles the Isle of Man crest and consists of three rays. A patch of phloem always occupies the interval between the xylem rays. All the other cells inside the endodermis are (I) unspecialised cells which are capable of further development. The xylem and phloem do not touch the endodermis, but are separated by a thin layer of these unspecialised cells, called the "pericycle."

The working of such a root is as follows. Water enters the root hairs by "osmosis," or diffusion through the membranes, and passes in the same way from cell to cell through the cortex, until the cells of the latter are turgid, or swollen with water. The pressure of the water inside these cells may amount to 3 atmospheres or $45 \mathrm{lbs}$. to the square inch. The diffusion invards or endosmosis of this water depends upon the density of the liquid within the cells, but the protoplasm exercises control over the process. It can, at will, alter the density within the cell by the secretion or extrusion of substances formed by itself. After a certain amount of water accumulates in the cortex, it is forced into the xylem tubes or water-conducting portion of the root. These tubes always tend to be emptied of water, because the water is being evaporated from the leaf above. They form a closed system of water pipes, so far as air is concerned, because the cork between the endodermis cells, above alluded to, prevents the entrance of air from the outside. The spaces between the cortex cells are well aerated; but air cannot get in through the endodermis elements on account of the cork between them. It must be borne in mind that water readily passes through the cellulose walls 
from cell to cell, but air generally travels in the spaces between the cells. The presence of air in the vessels might indeed altogether prevent the rise of the water or sap.

From the leaves the food material travels downwards by the phloem tubes and eventually reaches the patches of phloem already mentioned, in the root; this food material will therefore be close to the pericycle on its outside; and, from the phloem, everything outwards (endodermis, cortex, and root hairs) obtain s its nourishment. The cells inside the phloem, between it and the xylem, are also supplied with food material from it.

As is shown in a longitudinal section, and the transverse section of a very young root, the formation of the xylem vessels is inwards, that is, new vessels are continually added on the inside of the original patches such as $x$, until all these cells become xylem, and unite to form the distinct chariot wheellike arrangement which has in this case four spokes. After this, it does not at first seem possible for any new water-vessels to be formed. That, however, is not the case, for the crescents of cells between xylem and phloem, which, as we have seen, are well supplied with food, begin to divide and increase : some of them, those to the inside, form new xylem, and others, to the outside, form new phloem. The root, in fact, begins to increase in thickness by the action of a cambium as in the stem (see pp. I60 and I6I). At this period of its life the root is probably no longer itself absorbing, it is simply carrying the water from the younger roots which have developed from it. The cortex cells are therefore no longer required; the pericycle cells will probably begin to form a cork ring or cylinder round the central con- 
ducting part; and, as the cortex cells are cut off by this from food, they wither and die away. But, long before this period, some of these pericycle cells have begun to produce new or branch-roots. It will be observed that the pericycle is, from its position near phloem and xylem, well nourished, and well supplied with water. One of the pericycle cells, generally one opposite a xylem ray, begins to divide and soon forms a bulging mass of cells, which grows outwards, or eats through the cortex, until it eventually reaches the outside, where it forms a new rootlet absorbing on its own account. Roots, with very few exceptions, arise in this way from the inside of the older roots. Obviously this is of advantage, as the water vessels, or xylem of the offspring, are in direct connection with the xylem system of the parent root. It is clear, therefore, that every detail in the anatomy of the root is exactly what it should be, if the working of it is conducted in the manner described above.

On the tip of the rnot there is usually a small cap of dead material, often slimy on the outside. This thimblelike rootcap protects the young cells underneath. It is perpetually renewed by the epidermis cells underneath, and this is necessary, as the rootcap must always be injured and destroyed in its passage through the soil. Some roots exploit the soil solely by means of their system of growing and branching roots covered with root hairs. But a great many, probably the majority, are assisted by certain fungi, which may be regarded as the servants or assistants to the root. The roots of common trees, such as the oak, beech, and hazel, are often clothed with a close-set mantle composed of the threads of these fungi. This mycortiza varies in colour from white to pink, golden yellow, or rusty-brown. 
These fungi belong apparently to very different species (Amanita muscaria, Lactarius piperatus, etc.), but there is a want of definite details as to their origin; it is, however, certain, that the development of the tree is very seriously hindered if they are not present. Not merely trees but many smaller bushes, like the Blaeberry, or even very tiny herbs like Monotropa, maintain a fungus assistant. These fungus threads are much finer and more rapidly developed than root hairs; they will thus ensure a more thorough search of every particle of soil for the valuable nitrates, sulphates, and phosphates. As the group of fungi are specialised to feed on decaying matter, they will probably be able to obtain food from or break up substances which cannot be absorbed by ordinary root hairs. (See Chap. XI.)

In addition to the roots, Mycorthiza and colonising stems already mentioned, the soil contains a very varied flora and fauna. Of this flora the bacterial population is probably of prime importance to agri culture (see Chap. X.), especially, in the way of breaking up the dead bodies of plants and animals in such a manner, that the material can enter the roots of other plants.

Amongst the animal population, the worm is of the greatest importance, and is probably essential in every sort of agriculture. It has been estimated that there are in $I \frac{1}{2}$ acres of arable land some 200,000 individual worms. Their burrows go down to six feet or more, and thus aerate the soil ; they drag down leaves to a depth of 3 or 4 inches, and assist in digging and working the soil generally. But their main duty is to eat earth for the sake of the decaying vegetable matter which it contains. After being rubbed into fine particles in their muscular gizzards, and after the humus material 
has been altered chemically by secretions from certain glands, it is deposited in the form of worm casts upon the surface, and is then distributed by rain through the soil. Charles Darwin estimated that on each acre of land, Io tons of earth passes annually through the mouths of worms, and is changed into rich and fertile humus.

The worm is by no means the only inhabitant of the soil ; but it so happens that its. function has been studied by Darwin in a classical work which should be consulted by every observer of nature. There are, however, many other soil inhabitants equally worthy of the same thoroughly close scrutiny. Moles, mice, voles, and shrews assist in keeping the soil full of oxygen; and there are many varieties of insects and their larvae, as well as woodlice, centipedes, etc., whose function is as yet obscure. A few, such as the cockchafer, wireworm, and June bug, spend at least one summer, and, in the case of the first, no less than four seasons, in devouring the roots of our cultivated plants, retiring to lie up in winter to the deeper parts of the soil. These no doubt have their enemies and parasites. Ants, and in warm countries white ants, also have their part to play.

Thus there are at least all the following distinct and different populations in the soil: (I) The root and colonising underground stems or rhizomes of the larger plants. (2) The fungus assistants dependent upon and attached to them. (3) The fungus enemies, probably one or more adapted to invade each species. (4) Insect enemies, which in most cases devour indiscriminately any roots and rhizomes that they find. (5) Mice and rats or other animals which also devour roots. (6) Worms which commence the process of turning decay-products 
into food for the roots. (7) Bacteria which, as will be seen in a subsequent chapter, form in themselves several distinct groups.

At every cultivation period all these seven populations are affected, and their relative arrangement is disturbed. Birds, such as the partridge, starling, peewit,

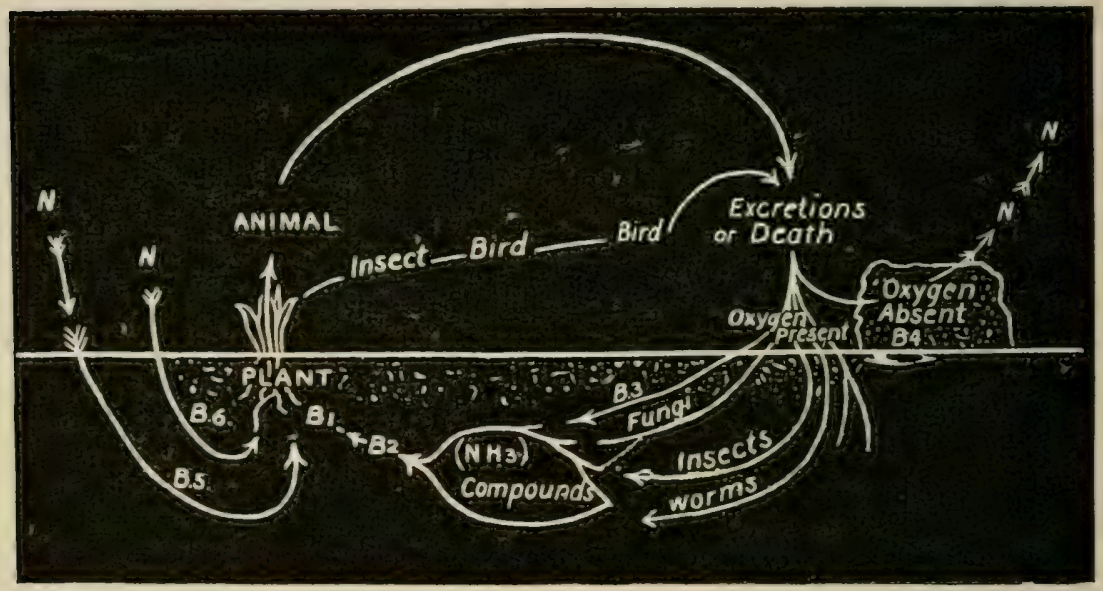

Fig. 13.-Nitrogen Circulation. The free (N) nitrogen of air becomes nitrates through bacteria (B5) of soil or (B6) those of leguminous ront tubercles, and as such enters the plant. The nitrogenous matter of an animal's body or its excretions will become free nitrogen by the bacteria (B4) of denitrification in the absence of oxygen, or in presence of oxygen by (B3) other bacteria will become ammonium compounds. The la'ter become first nitrites by work of ( $\mathrm{B} 2$ ) bacteria and then nitrates by work of (BI) bacteria, and as such enter the plant. (See also p. 202.)

crow, and seagull destroy millions of insects in every season; and man and the larger animals also interfere in their distribution. Under the best natural conditions, there is a distinct tendency for the soil to improve with every season; almost the entire organic matter formed by the year's working remains in the soil for the benefit of future generations ; for example the nitrogen from a dead bird may traverse successively the worm, two or three kinds of soil bacteria, and the roots and leaves of plants: it may 
then pass through an animal's body, but it will pass back to the soil eventually. Man interferes with this natural improvement by withdrawing crops and animals for his own support. $\mathrm{He}$ is therefore obliged to intercalate fallow with his ordinary farm crops, in order to permit nature to form the soil afresh. 


\title{
CHAPTER VII.
}

\author{
FOLIAGE.
}

Guarda il calor del sol che si fa vino Giunto all 'umor che dalla vite cola ;

DanTE, Purgatorio, XXV. 77.

From the lines that are here quoted Dante appears to have grasped more or less distinctly a very important botanical fact. It is the sunlight, which affords not merely the energy of wine, but the motive power which carries on the life of plants, and of all the animal world. The leaves are intended to absorb the light (or, strictly speaking, certain rays, the red, orange, yellow, and part of the blue rays of the spectrum); and, this absorbed light is utilised by the plant, as a supply of energy with which to build up the complex substances on which life depends.

It is necessary to begin this chapter by a short explanation of the whole process ; because it is impossible to appreciate the beautiful arrangements which exist in every detail of leaf shape, without a knowledge of the object for which all foliage exists.

Leaves are intended to intercept as much sunlight as possible, and also to obtain, from the air, the carbon which is necessary for the plant food. By the aid of this intercepted light, the leaf manufactures sugar, by combining the carbonic acid gas of the atmosphere with the water which is supplied to it from the root. Very little 
is known as to the exact details of this process ; but, it is certainly the green colouring matter of the leaf which absorbs light and heat from the sun's rays. Carbonic acid gas and water are then made to form sugar by the action of the small living chlorophyll bodies, or chloroplasts. These are very numerous, about 400,000 having been counted in a square millimetre of the leaf of the Castor-oil plant. ${ }^{1}$

The importance of leaves depends on the amount of sunlight-energy which they are capable of intercepting. In countries such as the United Kingdom, the hours of sunshine are by no means excessive. The south coast of England and Ireland, part of East Anglia, and a very small part of Wales and the Isle of Man, are the only districts of Britain which "enjoy even the moderate amount of more than 1500 hours of sunshine annually, whereas practically the whole of Germany and even St. Petersburg have at least that number of hours of sunshine. It follows that, in such a country as Britain, every plant must so shape and arrange its leaves that they will lose as little as possible of this scanty allowance of sunshine. Hence we find in most British plants a tendency for the leaves to fit together like the pieces of glass in a mosaic, so that a

${ }^{1}$ The actual process is probably as follows:

Carbonic Acid splits into carbon monoxide and oxygen; water splits into hydrogen and oxygen; the separation is due to the action of the chlorophyll bodies, or chloroplasts, which utilise the energy absorbed in the chlorophyll.

$$
\begin{aligned}
6 \mathrm{CO}_{2}+6 \mathrm{H}_{2} \mathrm{O} & =6 \mathrm{CO}+6 \mathrm{O}+6 \mathrm{H}_{2}+6 \mathrm{O} \\
& =6 \mathrm{CH}_{2} \mathrm{O}+6 \mathrm{O}_{2} \\
& =\mathrm{C}_{6} \mathrm{H}_{12} \mathrm{O}_{6} \text { (Sugars) }+6 \mathrm{O}_{2}
\end{aligned}
$$

It follows that the rolume of $\mathrm{CO}_{2}$ taken in approximately, equals the volume of the oxygen given off.

Moreover, fires cannot go on burning if oxygen is prevented from reaching them, so that when the sugar is destroyed by burning, oxygen must be taken from the atmosphere. It follows that in the original making of sugar, oxygen must have been given back to the atmosphere. 
spray of foliage, or the leaves of the whole plant form a nearly perfect light screen. It is in this necessity for fitting closely together so as not to lose any of the sunshine, that we find an explanation for the varied and beautiful shapes of leaves. The idea, namely, that of covering a blank space without crowding, is essentially the same as underlies all decorative art of the nature, for instance, of wall-papers. Hence leaf-shapes, as a rule very imperfectly understood, form the groundwork of most art work of that kind.

The outline of the leaf is, in a general way, governed by this mosaic necessity; but the details of its shape are affected by the balance of the leaf on its stalk, as well as by the necessity that it shall move freely in the wind, and by other considerations.

The following are amongst the important shapes of leaves :

(I) Leaves broadest near the base or stalk, such as ovate (egg-shaped), lanceolate (lance-head-shaped), cordate (heart-shaped).

(2) Leaves as broad in the middle as anywhere else, such as linear (long and narrow), oblong (brick-shaped and rounded at the edges), circular, etc.

(3) Leaves broadest near the tip, such as obovate, oblanceolate, obcordate, which are similar to those of the first group in outline, but the stalk is attached at the narrow end instead of at the broad. These forms include also the spathulate or daisy leaf.

The examples which follow are chiefly from very common plants. Wherever they are intelligently looked for many others will be found.

The Daisy has a very dense and close circle of leaves, forming a little rosette or tuft, which is flat and pressed close to the ground. The leaves, therefore, cover and 
suppress the young grass blades which try to grow up underneath them. Daisies, as a matter of fact, tend to spread over, and occupy exclusively any grass lawn which is continually mown. Examining a daisy plant closely, it will be seen that the older leaves are broadest near the outside and narrow down towards their insertion. This stalk-like part of the leaf is not green but whitish in colour. Looking down on a daisy rosette it is easy to see that the oldest leaves nearly touch one another, and that there are some eight of these. The stalk parts of these old leaves are covered by young leaves, which very often just overlap the bare space on each side, through which, if they were not present, some intrusive grass blade might find its way. The very youngest leaves of all are erect and curved round. Hence the "spathulate" shape of the daisy leaf is not a matter of chance; but, as one can see from the figure, is determined by the number of leaves, namely eight, among which the light is shared, and the necessity of catching all the light that falls on them.

In the common Garden Saxifrage, London Pride or None-so-Pretty, a very similar arrangement is found, and in this case also the leaves are eight in number. The Woodruff (Asperula odorata), which has its leaves arranged in little circles of eight along the stem, shows the object of the "oblanceolate" leaf of botanists. They are widest at some distance from the stem. For two-thirds of their length they are very nearly triangles with an angle of about $45^{\circ}$, so that the eight together form a complete circle intercepting all the sunlight that falls on the space. The circle below is slightly twisted, so that its leaves come between those of the whorl above. The garden Lupine again has very large leaves which 
are compound or "digitate," consisting of several leaflets springing from a stout stalk. Each leaflet is very similar in shape to the leaf of the woodruff, and for the same reason. The whole leaf catches all the sun-

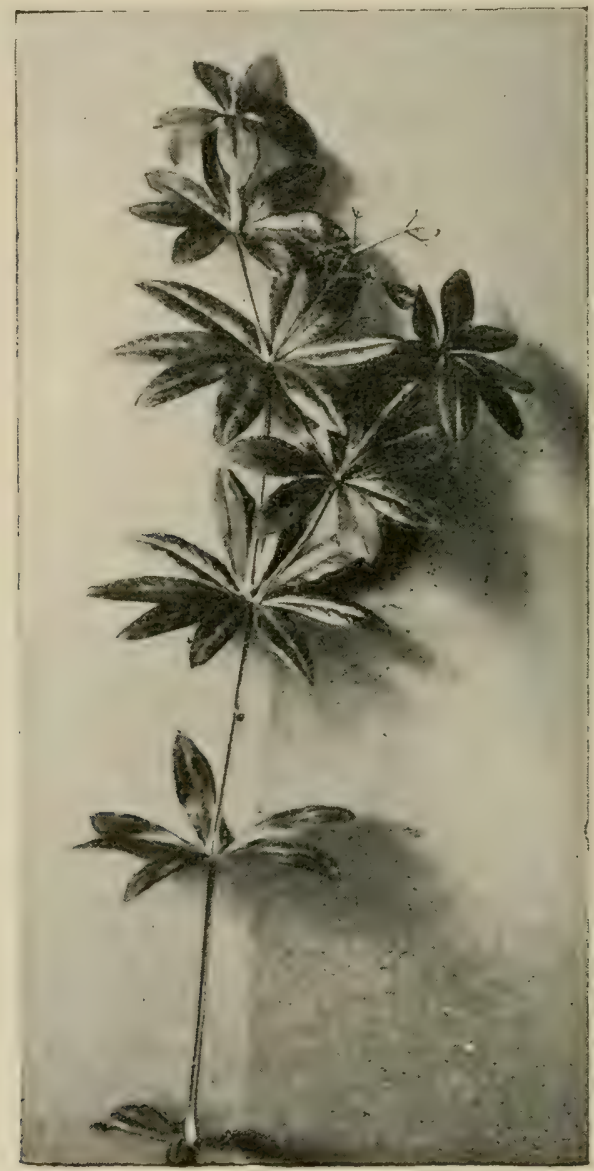

Fig. I4.-Leaves of Woodruff (Asperula odorata).

light that falls on the space which the leaflets unitedly cover. The number of leaflets is, however, in this case rather variable. Sometimes there are eight, but there may be twelve or more, as the plant, being a cultivated one, is not so rigorously economical as a wild one would 
be. The leaflets here also nearly touch one another along their base.

Rhododendrons sometimes show at the end of their branches a circle of leaves which very nearly touch; but in this case the number is variable, often 8 or 16 . On the other hand, many plants have their leaves arranged in pairs opposite one another, and the pairs cross at right angles, so that here the light is divided amongst four leaves. The Nettle, and almost any plant belonging to the great natural order Labiatae, show this clearly. The leaves are broadest at the base, that is the part nearest the stem. The very small young leaves cover any space that would remain above the stalks, and a clump of nettles will show the student very clearly how these "ovate" leaves prevent any stray beam of light from getting through. In fact, scarcely anything is able to grow below a well-developed clump of nettles. Lord Avebury in his book, Flowers, Fruits, and Leaves, which should be a classic for every naturalist, gives an excellent figure of a spray of Horse-chestnut showing how the shape of the leaves, the length of the stalk, and the angle of the leaves to it, all contribute to make the shade which this tree throws as nearly perfect as possible. The leaves, however, are in this case "digitate." A young sunflower, before the flower is developed, also shows how the heart-shaped and pointed or "cordate" leaves may be combined to form a beautiful dome of foliage of a very effective nature.

In all these cases, however, the light is supposed to fall upon the top of an upright stem, and the leaves all round the stem share this light among them.

Three of our common trees, the Beech, the Elm, and the Lime, have a different arrangement. Here the branches are more or less horizontal or drooping and 
the leaves are placed alternately along them. The arrangement in the case of the Beech is perhaps the simplest and most effective, and its shade is certainly very complete, for practically nothing is able to grow in a close plantation of beeches except the seedlings of the plant itself. The twigs are not quite straight, but zigzagged. The zigzag is occupied by the upper basal margin of a leaf, the rest of the upper margin being

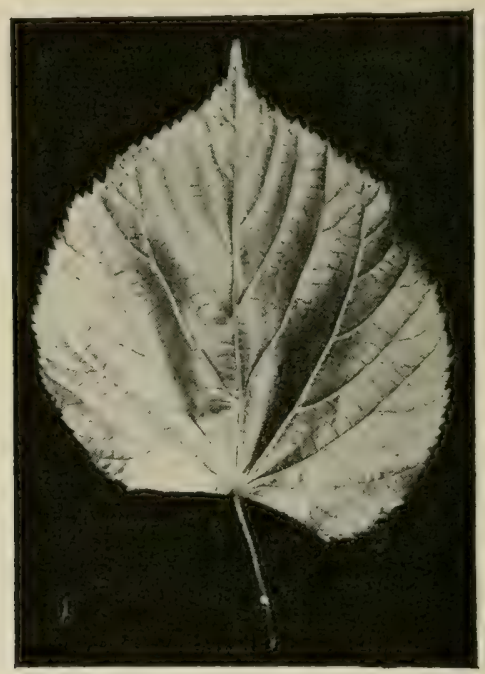

FIG. I5.-LEAF OF LiMETREE.

next the lower basal part of the leaf above and fitting closely to it. The outer terminal part of the lower half of the leaf has a shape probably determined by considerations connected with the weight of the leaf, though the outline bulges out in this part as far as it can.

In the Lime the twig is nearly straight, but the leaves have rather long stalks, and are unsymmetrical at the base, one base-half, the farthest from the stem, starts with a wide lobe which covers the space between its own stalk and the twig and the stalk of the leaf 
beyond it ; the other base-half, that nearest the trunk, is cut away to fit to the outer margin of the leaf which is below it.

Thus the difference in the shape of the leaf lobes at the base is of the greatest importance, and is not a mere detail which cannot be explained. In the Elm also there is a curious want of symmetry at the base of the leaf, one half of which comes much lower down the stalk than the other; but, by placing the branch at the correct angle to the light, it is easy to see how the larger lobe occupies a space which would otherwise allow light to pass.

The Silverweed (Potentilla anserina) and the Meadowsweet (Spirea ulmaria) have rather large leaves for the size of the plants. These leaves are "pinnate," i.e. consist of a series of leaflets arranged along a common stalk. They further possess little supplementary lobes placed along the midrib between the stalks of the leaflet. These supplements are of importance; if the leaf is slowly turned up and down, it will be found that at a certain angle, corresponding to the direction of light, the small additional lobes exactly fill a vacant space between the stalks of two leaflets.

On the other hand, when the leaf is free to expand in any direction, as, in the case of the Water Lily, it becomes nearly a circle; for obviously there is no special reason for its growing further in one direction than in another. Kerner and Wiesner and Lubbock (Lord Avebury) give many other examples; and almost any wood, or hedgerow, or garden, will soon supply material to the student. There are, however, very many apparent exceptions and irregularities, and these are apt to be confusing. Both the beech and the elm are cases in point. The beautiful figure in Kerner's 
Natural History is totally different from the arrangement described here, except as regards the four end leaves of the branch. At the junction of two side twigs, the leaves are displaced, and have entirely altered their size, so that small ones are arranged between the larger. The result is a very pretty piece of mosaic work, and illustrates very well the important fact that, though Nature works on hard and fast mathematical lines, room is always left for special necessities, and free play is allowed for variations adapted to the unforeseen. The development of the leaves depends, as a matter of fact, on the amount of light which they obtain and this limits their growth. Each leaf has also its own motion, and is not held to one special position, or hard and fast form.

At first, it is not easy to understand a very simple cause of confusion. The light is very seldom decidedly overhead. It is often entirely from one side; or it may be diffused and broken up by other leaves, and this alters at once the arrangement, and even the shape of the foliage. A sort of leaf very common in climbing plants, and of a very neat mechanical structure, is difficult to bring under any law whatever. The leaf of a Convolvulus or any ovate, acute or acuminate leaf, heartshaped at the base, will explain this type. Yet it is not difficult on examination to find the theory of this shape. The tip fits either into the space between two neighbouring leaves, or into the little notch at the base of one below, and thus saves light.

The light-catching effect of the whole leaf again depends, not on its actual shape, but on the amount of light which it intercepts; or, we might say, on the shadow which it throws. If a dandelion leaf is copied on cardboard and the latter cut out to the shape, then 
by placing the model at different angles to the light of a candle a whole series of shadows corresponding to actual leaf shapes may be seen.

It must also be remembered, that a very large proportion of wild plants never have any chance of catching all the light that falls on them. They grow amongst many other species, and have to develop their leaves in any opening which they can find. In a grass field, for example, most of the leaves are long and narrow, or "linear," and most of the weeds which grow there, either have leaves like the grass, such as Plantago lanceolata, Mouse-ear Chickweed, Knot-grass, etc., or their leaves, like those of the Butter-cups, are finely divided, and cut up into thin segments, which can sway freely in the wind, and adapt themselves to their special circumstances.

It is, however, abundantly clear, that the shapes of the leaves which make up either the foliage dome of a Horse-chestnut or the interlacing criss-cross of blades in a pasture field, are such that in Britain, at any rate, the tint of the landscape is always green, and entirely masks the colour of the soil.

The arrangement of the cells which make up the leaf is entirely controlled by the necessities of their work. This can be easily seen by examining, for example, a transverse section of the leaf of Skimmia or Laurustinus.

As will be seen from the diagram of such a section, there are from above downwards: (I) The single layer which forms the upper skin or epidermis with thickened outer wall. (2) One or two layers of somewhat drawn-out or lengthened cells, the "palisades" full of the rounded chlorophyll or leaf-green bodies. It" is in these cells that the sugar is formed. (3) The irregular mass (to the right) in a cavity lined by small 
cells, consists of resinous or other protective substance intended to keep off insects. (4) Chains of variously shaped cells, which unite the upper epidermis to the lower, and which leave many spaces between them-

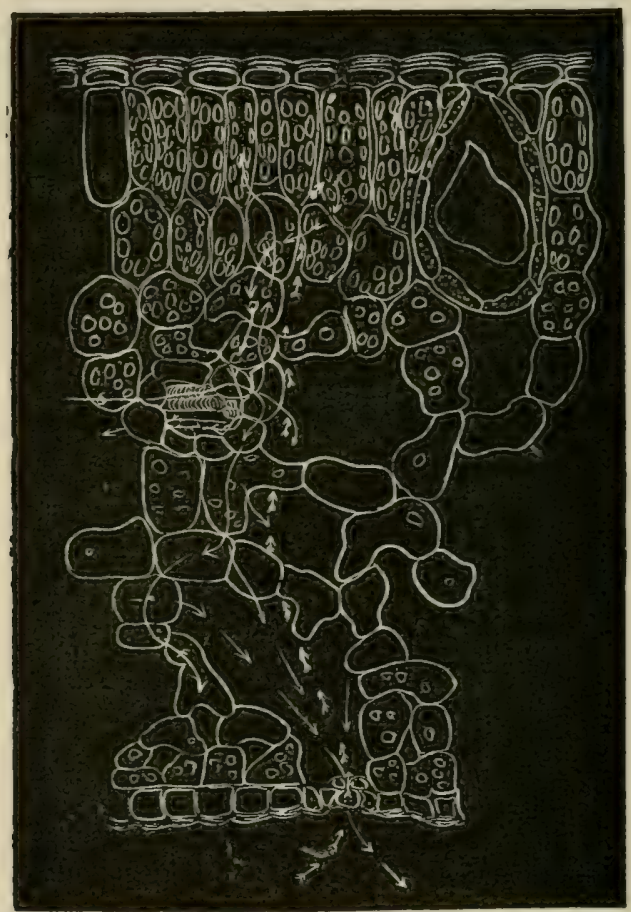

Fig. i6. -Transverse Section of a Leaf. From above downwards, first the narrow thick-walled "epidermis" cells. Next two rows of long, upright "palisade" cells with many round chlorophyll bodies in each. To the right a large resin-gland, which is protective. From the palisades to the lower epidermis, which is pierced by a pore or stoma where the arrows enter, are the lonse spongy cells, and in them, not quite half way down, is a nerve or vascular bundle consisting of spirally marked xylem vessels above a few phloem tubes. Both are enclosed in a circle of cells or bundle sheath.

some of these have chlorophyll bodies and others none. (5) A small nerve is shown in section near the centre. It consists of two or three waterpipes or xylem tracheids, with spirally wound thickenings, and below these of a few food conducting cells or phloem; both are surrounded by a circle of cells, the inner-skin or endo- 
dermis. (6) The skin or epidermis of the lower surface which is interrupted by a small "stoma" or pore.

This leaf is a fairly typical one, but as a rule the long cells (2) or palisade cells are more conspicuous. In some leaves, however, there are long cells on both sides of the leaf, and in others there are very few spaces between the cells. The resin-gland (3) is unusual, though protective crystals or hairs are common. The working of such a leaf may easily be followed by means of the small arrows. The barbless show the course of the water-particles. Entering the leaf by the xylem tracheids, the water diffuses into every cell ; most of it eventually, evaporates into the spaces between the cells, and passes out by the stomata (transpiration). A regular stream of water mounts into the leaf, and this evaporation ${ }^{1}$ or transpiration has a great effect in producing it. The palisade cells require a continual stream of water, not only to keep them distended and fresh, but also to bring to them continual supplies of nitrates, sulphates, potash, etc., in solution. This ascending sap or transpiration current may be compared therefore to a navigable river which brings them food material as well as water. Part of the water, however, enters the long palisade cells, and there meets the carbonic acid gas particles which (small arrows with two pair of barbs) have entered the stomata and eventually found their way by the spaces between the cells into the palisades. By the work of the chlorophyll bodies, the water and carbonic acid gas are made to unite, forming first sugars, and then, by the addition of nitrates, etc., more complex bodies. These substances pass (as shown by long arrows with one pair

${ }^{1}$ This process is not mere physical evaporation as it is controlled by the living protoplasm of the cells. 
of barbs) into the phloem, and are conducted down into the phloem of the stem or root. The green chlorophyll absorbs the sunlight energy as has been already explained.

A leaf generally consists of three distinct parts: the flat green blade, the stalk, and the base. It is in the flat portion that most of the carbon-assimilation is carried on, but sometimes the blade is assisted in its work by a flattened stalk (Acacia, Orange), and very often the base of the leaf has a pair of "stipules" which, though generally scaly, are sometimes green (Pansy).

In examining a leaf in the field, it is best to commence by noticing (I) the pattern of the leaves and their individual shapes. Other important details regarding leaves are: (2) their method of over-shading or over-reaching other leaves; (3) their adaptations for rain; (4) their protection against wind; (5) their mechanical support; (6) their means of defence against insects and fungi; (7) their arrangement for budprotection; and ( 8 ) their autumn colours.

The Daisy is a good example of an over-reaching leaf, which is employed as an offensive weapon against other leaves. Any rather neglected pasture will give other good examples of a similar kind. One of the very best is the Cow-parsnip (Heracleum spondylium). The leaves appear above the ground in a very humble and tightly folded condition; but, when the plant is fully developed, the leaves may be eighteen inches long and nine inches broad, and form broad curved arches which cover over the grasses and other plants, and rob them of the sunlight. The Ragwort (Senecio Jacobea) on its first appearance is also very inconspicuous, and the leaves only over-reach their neighbours, when the plant is tall enough to be above their competition. 
The Coltsfoot leaves are upright when they begin to unfold: then they turn over so as to be horizontal, and rapidly overspread everything in the neighbourhood. The Burdock and the Giant Coltsfoot, as well as the Common Rhubarb, are all good examples of these overreaching leaves.

Those plants, which have a main root developing vertically downwards, very often arrange their leaves in such a way that water falling on the leaf must trickle to the centre of the stem, from which it will run down to

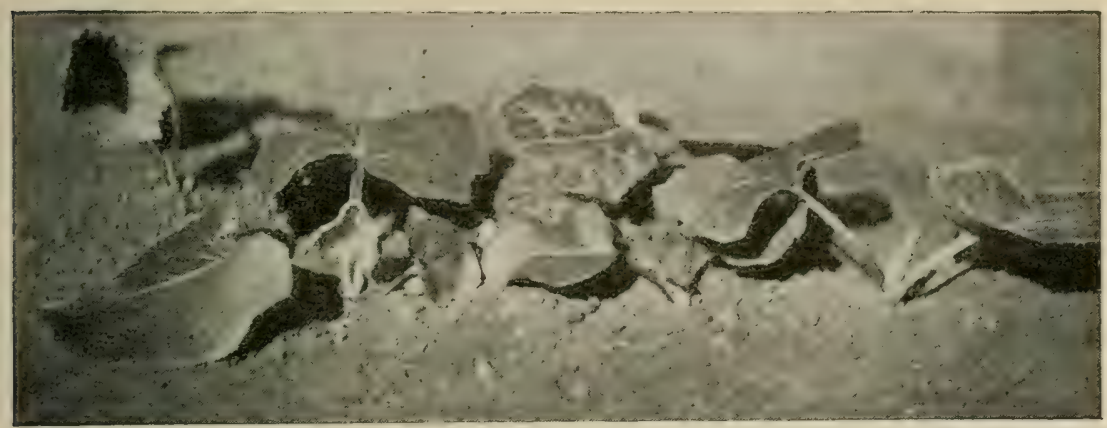

FIg. 17.-COLTSFOOT. The upright, white and woolly bud-leaves can be seen nearly erect at first, but in the older specimens becoming dark green and bending over. The hard points on the edge of the leaf can be distinguished on the older specimens.

the roots. The Common Lettuce shows this very clearly, as every drop of rain falling on the broad leaves must run down to the root. In those plants in which the leaves stand out at an angle inclined upwards, the rain generally runs down the leaf stalk and then trickles down the stem, and sometimes the leaf produces, at its point of attachment, two little lobes, or auricles, which direct this rain current, and make it travel along the stem. This arrangement can be easily seen in the groundsel.

It is not unusual to find that the leaves thus assist 
the root in obtaining water. Besides, as the rain passes over the foliage and stem, part of it is absorbed and the moisture so obtained refreshes the plant.

Thus, in the Chickweed, a line of hairs occurs along the stem, changing at every leaf-insertion. The rain travels down each pair of leaves and then runs down this line of hairs, these absorbing as much of the moisture as they can en route. Other well-known examples are those of the Ash leaf, which has a deep groove along its stalk in which lie absorbing hairs, of the Blue Gentian, which has deep grooves with similar absorbing threads at the base of every leaf, and the Gean-tree (Prumus avium ). This last is very remarkable, as special absorbing discs have been produced on the stalk just below the flat green part of the leaf. These little glistening discs or dots are generally supposed to suck in the rain as it travels down the leaf, and so to refresh the tissues. $^{1}$

In all the above examples, the rain is intended to travel inwards and refresh a vertically descending root, but in many cases the roots travel horizontally or are widely spreading, and extend just beyond the shade cast by the plant. In such cases the rain is often deliberately conveyed from leaf to leaf to the very outside of the foliage and there it drips to the ground. This, for instance, is probably the reason of the long drawn-out tips in such leaves as those of the Lime or Elm. The water drains off by these "acuminate" ends, drips to the foliage below, and so passes outwards. About $30 \%$ of the rain never reaches the ground as it is absorbed on the way. The Nettle and most Labiatae with pointed or acute leaves allow the rain to pass in the same way to the outside.

${ }^{1}$ Sometimes described as "nectaries" intended to attract ants. 
By a close examination with the lens, it is generally easy to find whether the rain passes down the stem or not. If it passes down dust particles accumulate towards the base of the leaves and thus explain the ordinary course of the water. Channelled or grooved leaf-stalks, as well as broad and permanent stipules, generally act as rain directors. It is also very easy to find out by experiment how the water travels.

A very neat arrangement to carry away rain is seen in almost all the grasses. The leaf consists of two parts of which the lower is a tube or sheath enclosing a white, delicate part of the stem, whilst the rest of the leaf is flat and green and is used for the ordinary work of assimilation. At the junction of these two parts there is generally a small white scale forming a distinct rim round the stem. Water coming down the leaf is turned aside by this white scale, or ligule, and cannot enter into the tube or sheath, where it might bring bacteria and cause decay in the soft stem tissue. But some British grasses, such as Melica, have no ligule and in this form the leaves droop over the stem which is also inclined in such a way that rain could not enter in any case.

Storms are fortunately worse in winter than in summer; but, nevertheless, the force exerted even by a summer gale of wind on a tree in full foliage is enormous. It is probable as Lord Avebury (Sir John Lubbock) has suggested, that many cases of divided leaves are to be explained by the necessity of offering only a slight resistance to the wind. The Rowan (Pyrus Aucuparia) has a flexible midrib and each leaflet can bend independently on its own little stalk. The Ash is particularly interesting to watch on a windy day. The branch bends over till it is as nearly as possible in a line with the direction of the storm. The wind then 
blows on the under surfaces of the leaves, whose stalks have a sort of conical shape, each being at a very acute angle to the stem ; each leaflet also twists, so as to get nearly as possible edgewise. Everything, branch, leafstalk and leaflet, sways to and fro, thus enormously diminishing the force of the air on the leaves.

In the Beech the natural position of the branches and leaves is nearly horizontal; the leaf is rather tough in texture, and is well strengthened by supporting veins; and the branch strives to keep the leaves edgewise to the wind, and does not bend like the ash.

It is very possible that many cases of much divided leaves, such as the Horse-chestnut, Geraniums, Umbelliferae, Leguminosae, Rosaceae, etc., can be explained by this necessity of supporting the wind. In many plants, however, the fine divisions of the leaf are intended to enable the leaves to be neatly packed away in the bud condition. This is very nicely seen in the Bishop's Weed and other plants of the same order, as well as in the Tansy (see Fig. 7, p. 68). At present there are unfortunately very few exact open-air observations which can be referred to in support of the explanation of leaf division here given.

In Poplars, the leaf stalk is very long and very flexible. It is quite different in shape from that of most other leaves, being compressed or flattened vertically near the blade; one of these poplar leaf stalks can be twisted round into two or three close spiral turns or corkscrew coils, without being in the least injured; the leaf can therefore very easily arrange itself edgewise to the wind and will not easily be torn avay. It is, however, the elasticity or flexibility of plants generally that is their main protection against storms. It is very interesting to watch grasses and reeds in heavy winds. 
Everything bends; the leaves turn about, and rippling air-currents pass along their surfaces, so that no harm is done. Amongst the worst sufferers from wind are Coniferae which are both in growth and appearance stiff and rigid, the leaves especially having very little pliability.

The methods of mechanical support shown in leaves deserve far more attention than has ever yet been paid to them. The Red or White Campion has a round stem, from which pairs of leaves spring. When the stem is held on a level with the eye against the light, the resemblance of these two curving leaves to arches springing from the top of a pillar is very close indeed.

The under surface of the leaves of many common plants shows a dense network of prominent veins, which gradually become thinner, and less prominent, towards the tip and edges. In some cases, when the leaf is held up in such a way that it is above the eye, it resembles in an unmistakable manner the fretwork often seen in the arched roof of churches; but it is of an infinitely more delicate and finished appearance. The thickness of the veins at the base is obviously very necessary. From a mechanical point of view the beauty of the arrangement in leaves is best judged from a comparison of two attempts by mankind to attain a similar result. A mason's crane and an umbrella, when compared with the leaf of the Lime or of the Pennywort, appear exceedingly roughly made. The curves of these leaves remind one sometimes of stone bridges, or of Norman, Byzantine, or Gothic arches of various kinds. Very often the shape of the curve varies in the same leaf. It is low and gentle in the main rib, but becomes much steeper or more Gothic in the lateral ones. The Common Bracken is a very 
excellent example of this. (The so-called "Oak" which one sees on cutting across the base of the leaf-stalk is the mechanical tissue.) Besides the supporting veins springing from the mid-rib or stalk, the lateral connecting nerves which hold these together are often of mechanical importance, as may be seen, for example, in the blackberry leaf. These, like the rim or hem on the holly leaf edge, diminish the tearing effect of the wind.

The shining glossy character of many leaves is supposed to be of some importance. In tropical climates, where there are very heavy rains and where the leaves of plants are subject to attacks from parasitic Algae or encrusting Lichens, it is of great importance that the leaf should dry rapidly. Moisture upon it favours the development of these enemies, and also the growth of fungus spores. It is found that in such climates a large proportion of the plants have leaves of a glossy character; and it is very probably the case, that the moisture dries more quickly on such glossy leaves.

The protection of leaves during their young and tender bud condition is, of course, very necessary. All sorts of mites, beetles, and other insects, are apt to attack the buds; and, besides these enemies, the young leaf has to be protected against changes of temperature, and especially against the loss of water in dry weather. Before the leaves take their final position as mature workers in the general economy, they are protected in all sorts of ways, of which the following are amongst the most easily observed. They may be :

(I) Rolled up or folded together in the bud.

(2) Covered with closely set silky or woolly hairs.

(3) They may have a red colour, due to a special 
colouring substance called anthocy'anin, which (Overton) may be produced directly by exposing leaves to sun at a temperature of $16^{\circ}-22^{\circ} \mathrm{C}$.

(4) There may be a gummy, varnished, or oily covering.

(5) They may be enclosed in an armour of overlapping scales, which are themselves leaves, or parts of leaves, modified to protect the bud.

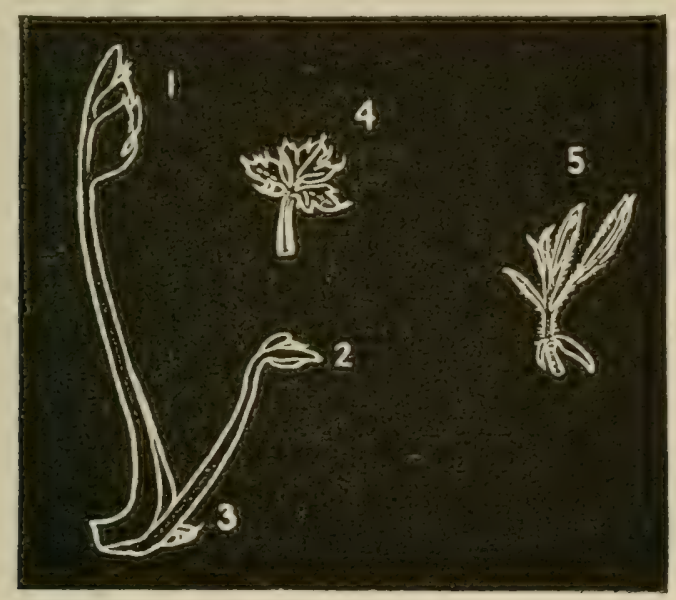

Fifr. I8.-Devfloping Leaves. (I-4) Buttercup (Ranunculus repens): (3) shows the edge of a very minute bud leaf scarcely free from the sheath of the older one 2 ; the leaf at $\mathrm{r}$ is about to expand into the normal mature position seen at 4. (5) Azalea showing the erect, hairy and folded bud leaves.

(6) Small hard tips occur on the teeth of the leaves, and, when young, guard the tissues below and between them.

Many botanical names are given to the ways in which the young leaves are rolled or plaited. Amongst the neatest and best arrangements are the following: The Lily of the Nile (Richardia Ethiopica)-not a Lily, but belonging to Araceae-has at the base of every leaf a little hollow sheath or tube. The young leaf is rolled up like a scroll of paper, and fits into this hollow 
exactly. The leaves of the Docks (Rumex), and most of the order to which it belongs, have a midrib, which is fairly prominent, even in the young condition. The green part on each side of the mid-rib forms a neat roll, which fits against it. A gummy or slimy matter often covers the young leaf, and the whole leaf, as well as the stem bud, is contained in a delicate white sheath belonging to an older leaf.

The common Bishop-weed (Egopodiun podagraria) sends up its leaves above ground in a very curiously folded condition. The leaf is bent over, so that the stalk and nerves are uppermost; the delicate green tissue is completely enclosed, and is entirely out of harm's way. Another very nice example of this mode of protecting the bud is the Dog's Mercury (Mercurialis perennis). The stem bends over as the leaf of bishopweed does, and the leaves have similar prominent nerves. In this case the green parts of the leaf are rolled in, and not outwards as in the dock. The curve or arch, formed by the bending over of the stem or leaf-stalk, is of importance, for the young leaf may have to grow up through grass or other obstacles, and this curved or dome-shaped summit can easily push its way through other leaves. As soon as the leaflets of the Bishop-weed, or the stem of the Mercury, have passed through the other leaves, they spread out in their natural position, and take the light for themselves. The Wood-sorrel is another excellent example of the way in which buds are guarded. The buds of those plants which have opposite leaves, usually show the successive pairs enclosed one within the other, in such a way that the mid-ribs of the younger pair fit into the space between the edges of the next older pair below. In the Wound wort (Stachy's silvatica) or in the Nettle, 
about five or six pairs of very young leaves may be counted, all following, and one inside the other. In Veronica anagallis, and (according to Mr. Paterson) in the Stitch-wort (Stellaria holostea), the bud leaves remain flat, and pressed against one another, whilst the internode of the stem is developing below them. The shape of the bud is in the latter case not unlike a lance, and it can be readily forced through any rank grass or other vegetation above; then, when it has reached the light, the leaves open out and turn sideways into their natural horizontal position. Very often, such a pair of leaves act as two supporting or grappling hooks, clinging to the surrounding vegetation so that the stem is supported by them. The curious downward curve of the leaf-tips in the Stitch-wort, and the little back-pointing teeth on the edge of the leaf of the Veronica, assist these plants to hold to the surrounding herbage.

It is quite exceptional to find leaves in the bud entirely destitute of hairs, although they may lose them altogether before they are mature. The young Colt's-foot leaf is entirely wrapped up in fleecy white cotton, which eventually disappears from the upper surface. The little Ivy leaf is also very prettily covered with a rougher and more mealy covering. In plants such as Vibumum lantana, which have " naked buds," a dense mass of hairs forms the only protection of the young leaves, but it is quite unnecessary to give many instances, as almost any plant in spring will be found worth examination. The Beech, Goose-grass, Stachys, Foxglove, and Verbascum are amongst the very best examples.

A dull red colour is also very characteristic of young foliage. The young shoots in a hawthorn hedge are 
often of a dull reddish-yellow, which contrasts with the green of the older leaves. There is little doubt that this red colour is due to a substance called anthocyanin, which is in some way protective, though there is some dispute as to its exact function. Some suppose that it is merely a sun-screen protecting the young tissue below from the injurious effect of too strong a light. Others maintain that this substance changes the light rays into heat, and thus assists in the chemical transformations going on in the leaf. From the point of view of an open-air botanist, the former theory is very satisfactory, for this colour certainly does appear exactly in the positions in which, on that supposition, it would be expected. The leaves of the Colt's-foot, of the Hawthorn, and of the Daisy, are all in their youngest state when they first become exposed to the light, nearly erect, so that they receive the light upon their edges, not upon the flat surfaces of the leaf. All along these exposed edges are small glistening knobs placed at the ends of the veins and coloured red. When the leaf is very young these knobs are close together, and would, if the theory be sound, decidedly protect the young leaf from sunscorch. They could scarcely be of much use on the second theory. These little round red points can be seen even on the mature leaf; but whereas the green part between them has enormously expanded, they are practically precisely the same size as they were when it had scarcely developed at all. These small, usually unnoticed dots show very nicely how a minute detail, which one would suppose useless, may be of the very greatest importance in the life-history of the plant. The gummy or varnished character of young leaves is also certainly of some protective value to them; it 
is probable that it hinders the loss of water from the leaf, and it may also prevent the attacks of Fungi and minute animal enemies.

The overlapping bud scales too are of great assistance. It is unnecessary to describe these at greater

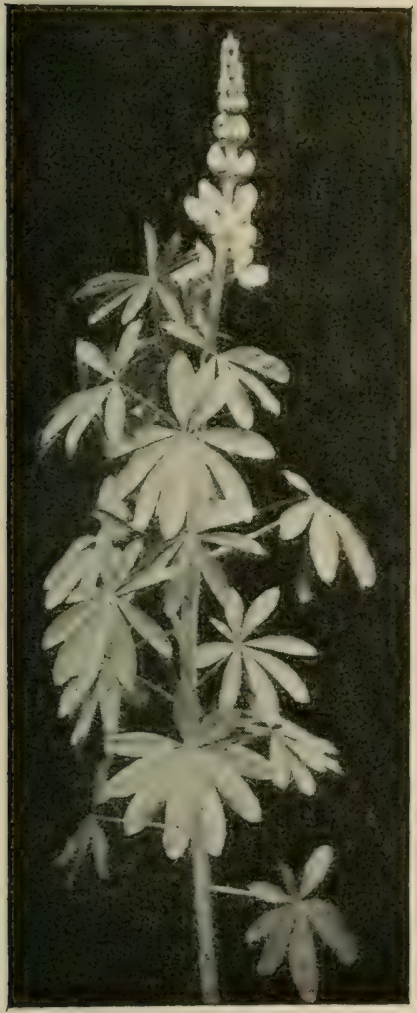

A.

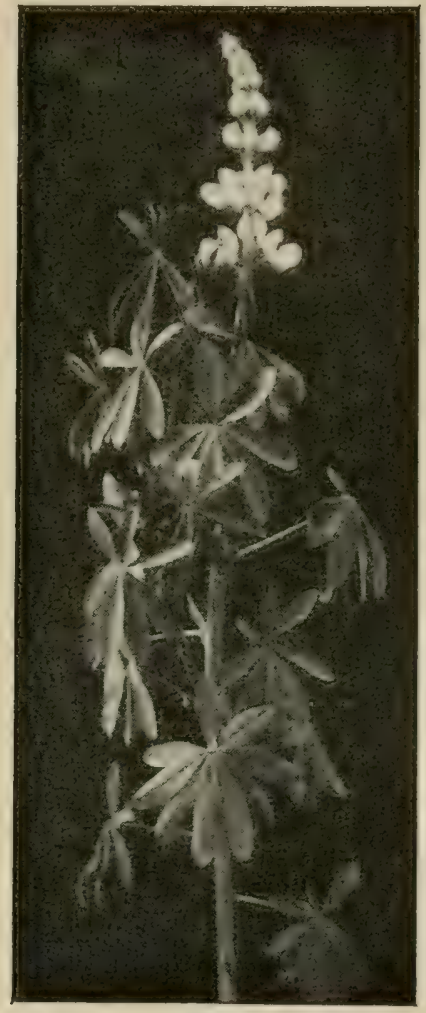

B.

FIG. 19.-LUPINE. The same plant in $A$ photographed about 12 noon and in $B$ about 7 p.m. The latter shows the evening curvature of the stalk and more verical arrangement of leaves.

length. Lord Avebury (Sir John Lubbock), in his book, On Stipules, has given a very perfect account of the whole question. In the Beech there are no less than 16 pairs, and in the Horse-chestnut 20 or more. Generally these scales represent either the 
stipules, wing-like developments at the base of the leaf, or the leaf stalk.

The life-history of a leaf is somewhat as follows: When the buds swell and develop in the springtime the young leaf begins to expand; the scales separate, and the stem internodes develop slightly. After growing for some time in this erect position, sideways to the sun, it bends over, and gradually takęs its place at the best available angle to the light, and - begins to manufacture sugar for the good of the tree. It is necessary to remember that it is by no means always in the same position. A great many leaves alter their position, or go to sleep, at night. Sometimes this "sleeping" position is very different from that taken up by the leaf during the day. When asleep, the leaf generally takes a more or less vertical position. Sometimes, as in the Wood-sorrel, the leaflets droop or hang from the stalk; at others, as in the Clover, instead of falling they rise so as to stand more or less vertically upright. In some Solanaceae and Malvaceae the sleeping leaves are brought much nearer the stem, as can be seen in the tobacco plant often grown in gardens. The reason usually given for these curious movements, is that heat is not so rapidly radiated from the leaves in this more vertical position; but we cannot say that this explanation has been proved to be correct. Under special conditions of the weather, also, leaves take up different positions. Thus, in severe frost the leaves of the Portugal Laurel hang almost vertically in a very $\operatorname{limp}$ and benumbed-looking manner. In very hot and dry weather, the leaves of Rhododendrons droop in a way which might lead one to suppose that the plant was utterly exhausted, and nearly dead. The Wood-sorrel may even be said to take a siesta, for in very hot 
weather, as it draws towards the hottest time of the afternoon, its leaves move into the regular sleeping position. Even in ordinary weather, and in the course of the day, leaves are scarcely ever in the same position. Slight movements take place which alter the inclination of the surface as the light shifts. The moisture in the air makes a distinct difference in the freshness of the leaf and its angle to the stalk. The point of the leaf describes irregular elliptic movements, greatly altered by the slight winds, which are scarcely ever absent in this country.

Towards autumn, there are signs that the leaf is becoming stiff and old. Its movements become more and more sluggish, and at last they cease to be perceptible. Changes of a very complex character, thereupon, begin in all deciduous leaves. Everything that can possibly be utilised by the plant is sent back to the stem, to be stored up in the form of starch, oils, fatty substances, etc., for use next spring. The chlorophyll breaks up; sugars, plastic matters, tannins, etc., disappear from the leaf, which is now a mere framework of cells, and of various fibrous matters which cannot be utilised.

Whilst these changes are taking place, the leaves show the exquisite autumn tints with which everyone is familiar. The red anthocyanin again appears, and, according to the character of the acids which are present in the leaf, gives a violet, red, or blue colour. These colours are not the same in every part of the country; and trees seem even to have an individuality of their own. Particular individuals frequently show a much deeper tint than others of the same species. The Rowan turns a brown or scarlet; the Birch becomes a delicate yellow; the Oak brownish yellow; the Alder 
a brown-green; Maples show all sorts of rich orange, or reds of one shade or another; and Willows become white or grey.

Just before the death of all the cells of the leaf, a breaking layer and cork sheet are formed across the base of the stalk. After all these preparations, the slightest breath of wind carries away the leaf carcase, which falls to the ground and is there promptly attacked by fungi, bacteria, worms, etc. These work up the dead matter of the leaf into the material for new leaves, just as worn-out locomotive engines are broken to pieces in the workshops to be manufactured into new, and probably better designed types.

Before closing this chapter it would be correct to give some sort of estimate of the work done by foliage, or of the energy which can be extracted from the sun's rays by vegetation and utilised by mankind. It is, however, not possible to do this with any sort of reasonable accuracy. A single leaf of a sunflower or pumpkin produces in a summer day of fifteen hours something like twenty-five grams of starch per square metre of surface (see Strasburger, Text-book, p. 20I). The most recent estimate of the rate at which leaves work is given by Dr. Horace Brown in his address to the British Association (Nature, I 899, p. 474). The leaf uses up about 600,000 calories per square metre of leaf surface per hour, of which a large amount is employed in evaporating the water which is being continually given off. The increase in dry weight amounted in his experiments to about one gram per square metre per hour. These results do not, however, give even an approximate idea of the way in which work is carried on by the sunlight.

Animal life depends upon foliage and food manu- 
factured by plants. It is not, of course, possible for any domestic animal to utilise all the vegetable matter grown upon any particular area, but a very rough idea of the work produced by plants can be obtained as follows:-A cart horse will require (from data kindly given me by Principal M'Call, LL.D.), some I 2 lbs. of oats, i 8 lbs. of hay, and 2 lbs. of bran every day. This means that at the average annual return in Britain, some $4 \frac{3}{4}$ acres must be set aside for its support. It is probable that, even the 1500 hours of sunshine which would fall on $4 \frac{3}{4}$ acres in Britain, is theoretically capable of doing the work of 3000 cart horses.

This does not seem to be very satisfactory; but it must be remembered that the oats, the hay, and even the cart horse, have been artificially selected by man, who has, in agriculture, the very roughest general idea as to what he is about.

This view of leaves as subservient to man, the more or less intelligent agriculturalist, is very decidedly necessary in any study of foliage, as it is, indeed, in each department of Nature study. 


\section{CHAPTER VIII.}

THE STEM.

STEMS and branches are intended to support the leaves, to hold them up above competitors, and out of reach of browsing animals. The inflorescence stalks, modified stems, also display the flowers to the best advantage. Besides this main object of placing leaves or flowers in the most favourable position, there are many other important functions which the stem has to fulfil. It must be mechanically well constructed to endure the mere weight of the twigs and leaves, as well as to stand against the uprooting effect of a heavy wind. It must contain stores of food material, to supply the buds when they develop in spring. Its outside has to resist the attacks of fungus and animal enemies, and must also prevent water from escaping during its ascent to the leaves. The increase in height of the Douglas Fir is sometimes a foot in a year; and, even though such trees as the Horse-chestnut only grow a few inches in height, still, this increase means a very much greater foliage weight and foliage surface, and as these new leaves also have to be supplied with water and food material, there must be provision for an increase every year in the diameter of the trunk.

It is possible to give a rough idea of the structure of a stem by a diagram, which will, at any rate, show how the main necessities are arranged for. 


\section{These are :}

I. Protection against insects and fungi.

2. Prevention of the escape of water.

3. Ascent of sap.

4. Supply of food material.

5. Storage of reserve food.

6. Provision for increase of thickness.

Protection against the attack of insects, etc., and prevention of the escape of water, are insured by the continuous cork sheath which surrounds the entire stem

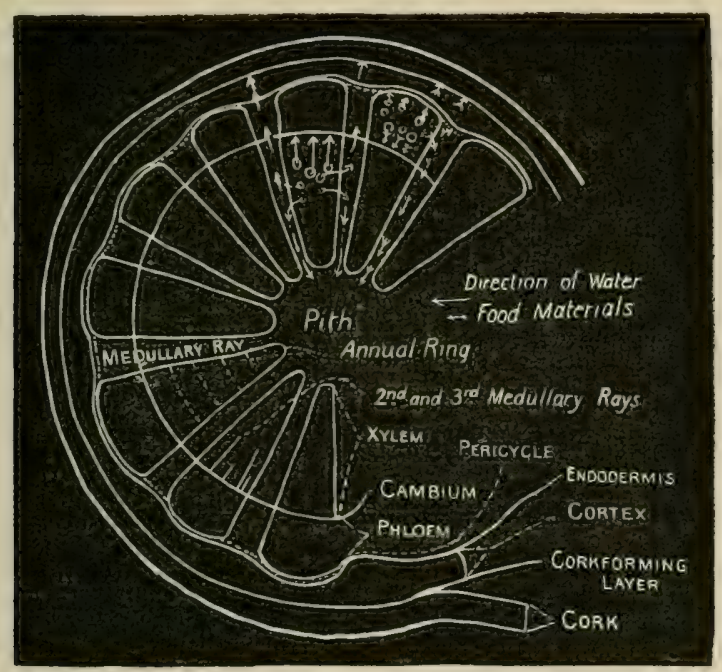

Fig. 20.-Diagram. Transverse Section of a Stem. Pith, medullary rays and cortex are composed of ordinary living cells.

of most trees. As shown in the diagram the arrangement of the living cells may be roughly compared to the circumference, spokes, and centre of a wheel. These living cells are used for storage of fats, oils, or sometimes starch in winter, and are, probably, essential for carrying on the work in all parts of the trunk. Between the "spokes," or medullary rays, are packed in the 
"xylem" (sap or water system), and the pipes for the "phloem," or food material. The latter is on the outside of the xylem. There is on each side of this phloem a circle of living cells; of these that on the inside is "the thickening ring" or cambium, which is used to form the new xylem and phloem every year (6). The other, on the outer side, is used to form new roots, and sometimes to produce mechanical or strengthening cells. This is the "pericycle" or "pericambium." The phloem is so placed, therefore, that the cambium on its inside and the pericycle on its outside, will at once receive all the food material brought by the phloem tubes. It will also be noticed that the spokes, or medullary rays, lie between the phloem patches, and will thus carry the food material from the phloem inwards to the pith and outwards to the cortex or rim. The water or sap coming up by the xylem will also reach the cambium first, and will travel, by these same medullary rays, outwards, keeping the cortex and phloem fresh, and inwards to the pith.

To complete the picture, it is only necessary to put in the cork-cambium, or cork-forming layer, just below the cork, and often formed from the outermost cortex cells. Thus there are seven concentric circles: the outside cork sheet; the cork-cambium; the cortex of which the innermost layer is the "endodermis"; the pericycle; the cambium; and the boundary of the pith. This, with the medullary rays crossing from the pericycle to the pith, gives a very fair picture of the average structure of a stem.

It is necessary to have a fairly distinct general idea of this structure, because the cells in a tree trunk vary so greatly in appearance and in character, that it is by no means easy to avoid confusion. 
The really important part is not the pith, which is of no special value, but the cambium layer. The cells here have a very remarkable shape, which governs all the cells that are formed from them. The shape is best understood by making a model as follows: Take two pieces of cardboard (I 8 inches long by 3 broad), lay one upon the other, and attach the two short ends by a strip of gummed paper. Then bend these cardboards slightly so as to leave an interval between them. Such a shape has many remarkable possibilities. Thus the cambium cells, when they divide, simply split lengthwise into two exactly similar shapes. Those cut off upon the inside become part of the xylem, those on the outside turn into phloem, whilst those formed in the medullary rays turn into new medullary ray-cells.

The xylem contains the following important modified cells. Water-conducting cells, tracheids, which are of the same shape as the cambium cells, but their living matter has been used up in forming a thick woody covering inside the original cell wall. The wood is not a continuous deposit on the inside but is laid down in the form of rings, spirals, or a network of woody matter: Thus, much of the original unthickened wall is left between the woody deposits, and the tracheid is strong enough to assist in supporting the other tissues, and yet forms a conduit through which the water ascends. In Pine timber, there is a nearly continuous woody deposit, but with pores of a peculiar shape, which probably act as valves allowing any injured tracheids to be cut off from the others. In such trees as the Lime, Ash, and Horse-Chestnut, vessels are found, composed of tracheids arranged one above the other, and with the divisions absorbed, so that the line of tracheids is an open pipe up which the (B 7) 
water travels freely. The walls of these vessels are generally pitted. Both the tracheids and vessels therefore are intended to conduct the water. Very often the mass of xylem is strengthened by dead strongwalled woody cells or fibres; often also the xylem contains living cells, especially when the medullary rays are few in number. In the last case, these living cells preserve a connection with the rays by means of which they are supplied with food material.

In the wood, or xylem, the medullary ray is formed out of a cambium cell, or group of cambium cells. Each cell is divided by horizontal walls into a tier of cells, of which the uppermost and lowest are triangular, or of the shape of a Gothic arch; these are generally without protoplasm resembling tracheids in thickening, and take in water which passes either into the central row, or upwards into other tracheids. The cells in the central row of the ray are full of protoplasm, and often contain food-stores.

The phloem part of the medullary rays only differs in the lowest and uppermost cells retaining their protoplasm, which is well nourished from the phloem, so that the whole medullary ray carries out food material to the cortex, and cork cambium.

Those cambium cells, which form the phloem, are changed into sieve tubes, phloem cells, or fibres. The sieve tubes are formed of curving, vertical rows of these cells. The transverse divisions are not destroyed; but are merely pierced by numerous openings, so that they look like a sieve. The phloem cells are formed either by the division of cambium cells, or they retain the original shape of the latter. The fibres are pointed, very much elongated cells, with extremely thick, woody walls, and are without 
protoplasm. They are formed by drawing out and thickening the original cambium cells. Owing to their shape, the ends dovetail into one another, and form an extremely tough tenacious bundle of stringy fibres, which sometimes protect the delicate phloem within from being compressed, or may even assist in strengthening the bark.

The pericycle sometimes forms similar fibres, or it may produce roots in those cases in which these are found on the stem, as in the Ivy. The cambium, as has been seen, forms every year new xylem on the inside, and new phloem on the outside. The wood, or xylem, formed in spring, contains many vessels, because at that time there is a sudden great demand for water to supply the developing twigs and leaves. In spring, also, all the food material stored up in winter is transformed, and made available for the cells, so that every life process is at its most energetic stage. Towards the end of the cambium's work for the year, the vessels formed are very few, and the cells produced are smaller and more thick walled. Thus the junction of the old wood of I9OI, and the spring-wood of 1902 is visible to the eye, and the so-called annual rings can be distinctly traced in most common trees. They are not easily seen in timber from tropical countries, where wood formation may go on during the whole year. The heart of the tree, i.e. the pith and the older xylem often becomes dark and discoloured later on in life, because resin and other substances accumulate in it. This heartwood is not used to carry water.

The cortex consists of living cells, which are intermingled with many others specially set aside for secretion, for strengthening, or as supporting fibres or strings. It is in the cortex that astringent tannins, resins, spherical 
crystals, hard-walled stone-cells, and collenchyma are -chiefly found (see Chap. V., p. 97, Defence).

The places in which food material is stored up are, as has been already stated, the pith, cortex, and medullary rays. After the fall of the leaves, a continual chemical

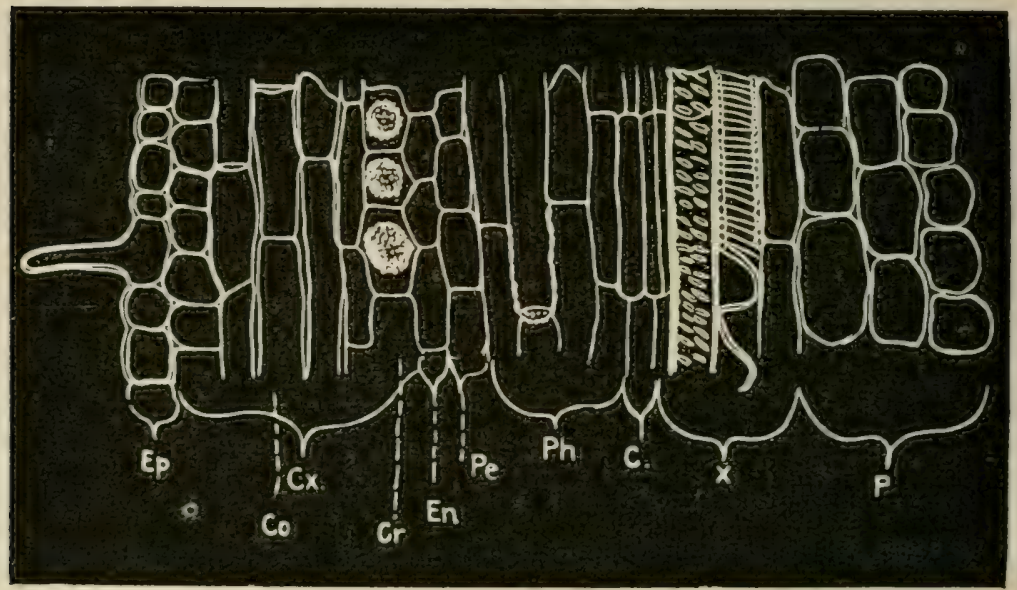

Fig. 2I.-Longitudinat. Section of Stem (Sparmannia). (Ep) Epidermis with one cell forming a hair. $(C x)$ Cortex, consisting of $(C o)$ strengthening Collenchyma, $(C r)$ Crystal cells, $(E n)$ Endodermis. $(P e)$ Pericycle, $(P h)$ Phloem, $(C)$ Cambium, $(X)$ Xylem and $(P)$ Pith.

change appears to go on within these cells, of which the nature and purpose is not understood. The most important point to remember is, that the tree lays up a store of food for the winter, generally of vegetable fats and oils, though sometimes of starch. These reserve foods are, on the approach of spring, transformed into sugars, and other substances which are able to diffuse readily through the cellwalls, and travel up to the developing buds. Some of these changes appear to be connected in some way with the light. It may be that they require protection from some injurious effect of light. It is this that, probably, explains the beautiful, if inconspicuous, colours of the twigs of trees. These 
vary with the species, and with the season. The Ash, has cinder-coloured twigs and black buds; the Beech, yellow or olive brown twigs, very different from the white of the old trunks; the Sycamore, greenish-brown twigs; the Sloe, Elm, Alder, Rowan, and Birch, show twigs with various red-brown or purplish tints; Willow twigs are yellow-green, but in some species may be purple; and the Dogwood is a bright warm-red colour. Probably these tints are due to the joint effect of tannins, green chlorophyll, the protective or warming red of anthocyanin, (see p. I 52) and cork. That the change is connected with the chemical transformations necessary for the foodstores, seems probable from the distinct series of colours through which Birch twigs pass as spring approaches. Sometimes, the food-stores are even utilised by man, as in the case of maple sugar of Canada, which is regularly drawn from the trees at the moment when it is fluid, and not yet utilised by the buds. The "plant springs" (Phytocrenes) are also tapped for water, and the sugary fluid or "pulque" of Agave Americana is much used in Mexico and other places, where it is said 50 kilos. of sap may be obtained from one plant. On the other hand, the sugar obtained from the Sugar-cane, that got from the various "Jaggery" Palms in India, and the starch of the Sago Palms and Cycads, is probably a food-store intended to help the plant when flowering. Sugars and starches are accumulated, in the case of the Sago Palm, for seven to eight years and dissipated in forming the flowers and inflorescences. That there is plenty of food material in certain stems, is proved by the manner in which small cuttings of willow branches take root, and produce leaves. This peculiarity greatly assists in distributing willow shrubs along river-sides. A prostrate log, of almost any species, often throws up a 
quantity of leafy shoots. Even the root and stool of a cut down tree contain much food material; and the method of regenerating forests known as "coppicing," consists in allowing these shoots from the stump to replace the original trees.

It is clear, therefore, that living timber consists of a whole series of live and dead cells, each of which has its own special part to play, a part which is subordinate to the necessities of the whole community.

The pressure of the sap within the wood vessels is often very considerable. In some cases it reaches an internal pressure of eight atmospheres, or I $20 \mathrm{lbs}$. to the square inch. This, however, is by no means excessive compared with that existing in the cambium and medullary ray cells, which is, according to some authorities, IO, I 5, or even 20 atmospheres, that is from I 50 300 lbs. to the square inch. ${ }^{1}$ This tension exceeds that of the steam in the boilers of an ordinary locomotive engine. That such a pressure is necessary can be understood if one remembers the height of trees and the amount of energy that must be expended in producing all the annual shoots on the outside of all the branches. Yet these cells in the medullary rays are by no means unhealthy It has been found that medullary rays, known to be 50 years old from their position, were still alive, so that existence at high pressure is not fatal to them. These tensions can be easily shown on a small scale by taking a fresh Dandelion, or the flower stalk of an Arum Lily, and slitting it lengthwise into four equal parts; the pieces at once curl backwards, and when put in water the rolling is very marked indeed. The inside part of each piece was

\footnotetext{
${ }^{1}$ D'Arsonval even states that an internal pressure of 160 atmospheres may occur in the cells of some mould fungi.
} 
greatly compressed, and the outside portion much stretched in the original condition. When set free the outer part contracts and the inner expands, and so produces the coiling up.

The ascent of water in the stem may be easily shown by a few simple experiments. Any healthy plant in full flower and foliage, such as a Fuchsia or Marguerite will be found suitable. The stem should be cut clean across at about I-2 inches above the ground. To the stump a glass tube may be connected by a piece of indiarubber tubing; another glass tube should also be connected with the base of the stem in a similar way. The first tube will show the manner in which the root pours water into the stem; the water accumulates in the glass and may eventually rise to three or four feet. One of the best plants to show this experiment is Sparmannia. A Vine stump $2 \frac{1}{2} \mathrm{~cm}$. thick has yielded five kilogrammes of water in a week.

The second tube attached to the stem of the plant will suck up water and show the daily supply which is necessary for the stem and foliage. This can easily be measured, and gives a vivid idea of the loss of water, or transpiration. The same method may be used to show that life is going on in branches during the winter. A leafless sycamore twig will not only absorb a large amount of water, but will even cure deep wounds by forming resin over the scar where a twig has been broken away. The water in the vessels and tracheids of stems in their natural state, is said to rise at a rate of from 36 to $154 \mathrm{~cm}$. per hour. The speed varies with the season, and with the hour of the day. Very little water seems to be used at night; the greatest amount is taken up generally about the 
hottest time in the afternoon. Spring is of course the most vigorous period. The actual causes of the ascent of water in the stem are generally supposed to be: (I) The Osmosis or absorption of the root hairs. This is partly osmosis (in the physical sense), and partly due to the living action of the root cells.

(2) The character of water itself which has a certain cohesion, which must come into action in the capillary passages of tracheids and vessels.

(3) The transpiration of the leaf-cells through the stomata or the lenticels of the cork sheet. This is partly mere evaporation from the spongy and other cells in the leaf, but is also due to their living action or control.

In the writer's opinion, it is also probable that the living cells of the stem assist in the raising of the water ; but this is expressly denied by some experimentalists.

It will be seen, that the facts known as to the tensions existing in the stem do not present any difficulty in understanding even such extraordinary growths as are shown in the following cases. A Eucalyptus has grown from a mere seedling to 45 feet in three years. This is of course a case of tropical exuberance.

The tallest trees appear to be the following:

Eucalyptus amygdaloides, -

Mammoth Trees of California,

Silver Fir,

Spruce Fir,

Pinus Sylvestris, Larch, and

$$
\text { Cypress, }
$$

I $40-152$ metres $459-498$ feet.

79-1 42

75

60

48-53
264-465,

239,

196 ,

The oak, ash, and other dicotyledons are seldom more than 33 metres or about Ioo feet.

In America certain herbaceous stems, also, are said to reach a great height. Wild Sunflowers I 7 feet high, 
and Chenopodium albidum I I feet high have been recorded.

The annual increase in thickness varies greatly according to the season and locality (see p. 3 I 7 et seq.). The age to which trees may grow is often extraordinary, but data regarding this are not easily gathered. Certain Californian Redwoods are said to have been 3300 years old, and European Cypresses and Yews are also said to exceed 3000 years. It is obvious, however, that a continuous existence in the same spot from B.C. I IOO to A.D. I902, must be exceedingly improbable. It is worth noting, that the more modern types of trees are neither so tall, nor so longlived, as the ancient Sequoias and other Conifers. In all other respects, the dicotyledonous Oaks, Beeches, etc., seem to be of a more advanced type. The Spruce, the Douglas, Araucaria, etc., show an exceedingly regular development of branches. The leaves are invariably small, and though a young thick-set plantation of Spruce forms a very dense and complete shade, yet in older stages this shade is either not maintained, or, only preserved by a continual dying off of all the older branches. The branching, on the other hand, of the ordinary dicotyledons, shows the most exquisite adaptiveness to any unforeseen conditions, and is never monotonous.

Very little is known of the causes which produce the various branch systems in deciduous trees. Of these there are two distinct types:- - those with opposite leaves, and those in which the leaves are arranged alternately. The branches of a Horse Chestnut may be taken as an example of the first method; the older branches begin next the trunk with a slight ascending slope; then they curve gently over and descend towards the ground, which they often nearly touch; and, finally, they rise again 
into an almost vertical position on the extreme outside of the foliage dome.

Both stem and branches have a natural bent, or tendency, to grow upwards, and to turn towards the light. Thus a young branch, starting inside under the shade of the older ones, grows outwards at an inclined angle. It compromises between the vertical position and the direction (the outside of the tree) from which light

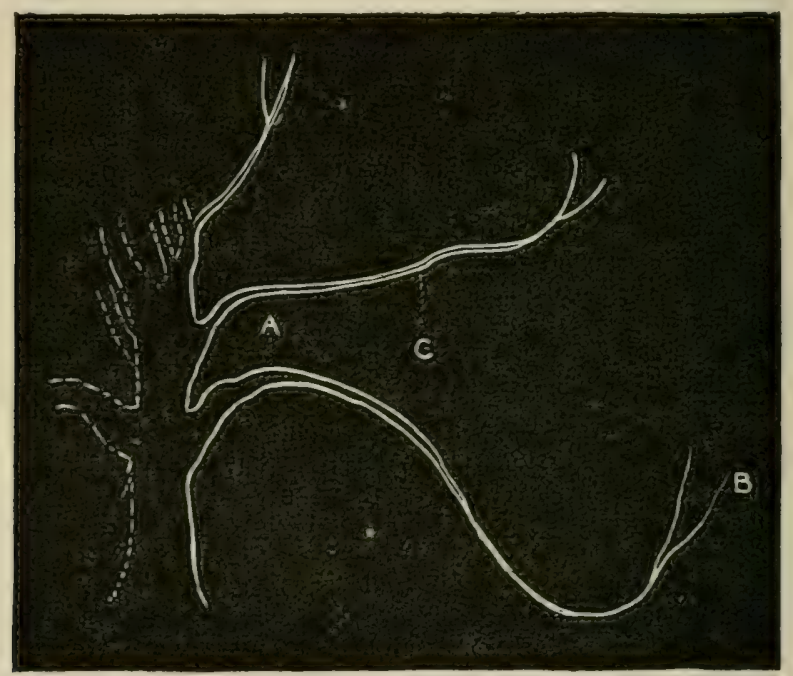

Fig, 22.-Diagram to show Tree Branches (see text).

is coming (Fig. 22). Thus one would expect a straight line uniting the points, $a-b$, but the result is a curve, which is infinitely more graceful. This is probably, as has been shown by Professor Henslow, due to the weight of the branch, which acts as a heavy weight hung at the centre of gravity ( $c$ in upper branch) would do, bending up the part $a$, and bringing the centre of gravity nearer the stem. In all trees the branches turn upwards as soon as they get out of the shade of the older ones. 
Quite a different kind of stem is seen in the case of the few monocotyledonous plants which form trees, such as the Date or other Palms.

They are not branched; the long midribs of the leaves replace the branches, and form a crown of foliage at the summit of the column-like trunk. The surface of the stem is also covered by leaf scars; and it is easily seen that it is built on totally different lines to those of ordinary trees. It is like a gigantic Dandelion, in which the tuft of leaves is produced every year on a new part of the stem, formed above the older one. Unless the leaves grow to a larger size every year, the area shaded does not increase with the age of the trees. Thus, these palms do not have a cambium, and do not markedly increase in thickness. It is clear, that the structure of a dicotyledon stem cannot be expected in this case, and in fact the formation is quite different. The phloem and xylem groups or nerves. of the leaf pass bodily into the stem, so that, when this is cut across, a great number of these groups are seen arranged in an irregular manner. Thus the stem is not to be compared to an Oak or Pine, but is on a different architectural plan. A thick-set grove of date palms has a very close resemblance to an Egyptian temple, like the Hall of Columns at Luxor; whilst an Ash wood shows a decided similarity to a Gothic cathedral, with relatively slender pillars and arches intersecting above. This is not surprising, as it is decidedly probable, that architects have borrowed many of their ideas from the trees with which they were acquainted.

The architecture, or strengthening arrangements, of herbaceous plants, both monocotyledons and dicotyledons, shows a wonderful variety; and the forms are sometimes exceedingly beautiful. This arises from the 
introduction of strengthening bands, or strings of hard and interlocking fibres, at all the places where strain is likely to occur. The Deadnettle or Woundwort, for instance, has a very weak xylem or woodring in the centre, but at the four corners of the stem there are strong ribs of fibres which hold the stem erect. If these ribs are carefully cut through with a sharp knife, the stem has no strength, and falls over at the slightest touch. In the three-cornered stem of many Sedges, such as Carex and Scirpus, the strong white supporting strings, placed in groups at different points near the outside, are separated by green assimilating tissue, and the result is exceedingly pretty, as well as of great efficiency. The Rushes, and the peduncles of Umbelliferae, are also worth examining. In many cases there is a central woody ring, and in the cortex, or under the epidermis, stays of fibres, so that the system resembles a ship's mast with supporting ratlines. This is the arrangement found in Jute, Chinagrass, Hemp, and other important fibre plants. The Carnation or Pink has a thick ring of strengthening tissue, which has the mechanical advantage of a hollow iron pillar, the supporting material being as near the outside as possible so as to give the greatest resistance to bending over.

Thus, the systems of strengthening differ greatly in different families of plants ; but, in every case examined, it seems clear enough that the strengthening or thickened fibres occur exactly in the position where the most strain is to be encountered.

It is almost certain that wood is a complex mixture, not a simple substance; and what little is known of its formation bears out this idea. The woody thickening in an ordinary tracheid, is certainly made up of layers deposited one after the other, probably from the inside. 
Plant and Tissue EMPLOYED.

Dianthus capitatus,

Dasylirion longifolium,

Dracaena indivisa,

Phormium tenax, -

Sanseviera (Greitach),

Hyacinthus orientalis, - -

Allium porrum, - -

Lilium auratum, -

Pincenectia recurvata, -

Papyrus antiquorum, -

Molinia coerulea, - -

Secale cereale, - _ _

Cibotium Schiedei, - -

Polytrichum juniperimum Stem,

Polytrichum juniperimum Capsule stalk,

Collenchyma (Ambronn), - -

Usnea barbata (Haberlandt),

Leaf-epidermis, Allium(Weinzierl),

Laminaria frond (Reinke), -

Thin-walled parenchyma (Schwendener),

Cotton hairs,

Seed hairs, Asclepias syriaca,

Cuticular tissues, Aristolochia (Damm),

Silver, -

Copper Wire,

Brass Wire, - _. - -

Ordinary Iron, . - - -

German Steel, - - -

WEIGHT AT WHICH

TEARING OCCURS.

Kilog. per

Kilog. per

EI.ONGATION

PER

1000 UNITS

OF LENGTH. sq. nim.

$7 \cdot 5$

I 3.3

17

13

12.3

14.7

I9

25

$2 \mathrm{O}$

22

I 5-20

$18-20$

$2 \mathrm{I} .8$

25

24.29

I6.3

17.6

50

38

7.6

I 4.5

I 5.2

I I

4.4

10

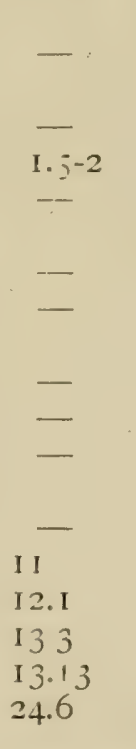

I I. 5

IO. 12

I. 7

I. 5 - I. 8

I

I

18-22

40.6

IO. I

29

- I

I. 3 ;

40.9

0.65

S2 
In some cases, it is suggested that the ultimate particles of each layer are really arranged in spirals, which run in different directions in different layers. If this is correct, then the structure of a woody tracheid-wall is produced in a manner similar to that employed in the manufacture of cannon, where each successive shell is made by winding a wire round the core. There is no doubt that the strength of the woody fibres and even of other vegetable tissues is very great.

The table on page 173 is given by Haberlandt from his own experiments and those of Schwendener, Weinzierl, Firtsch, and others.

The ingenious methods by which these results have been obtained and other details are to be found in Haberlandt's text-book. The above examples are sufficient to show the extraordinary tenacity of vegetable tissues. To this, and to the application of strength in the exact position where it is most required, is due the extraordinary engineering seen in such cases as the Ryeplant, which, with a diameter at base of only $3 \mathrm{~mm}$., may spring to a height of I $500 \mathrm{~mm}$. A factory chimney $367 \frac{1}{2}$ feet high supposed to be the tallest in England has a diameter at base of 57 feet.

The extraordinary flexibility of woody tissues is quite as remarkable as their strength, as can be easily realised by watching the branches of Birch and Ash on a stormy day. The toughness and strength of wood renders tree-stems invaluable to mankind; and it seems unfortunate, in view of the coming scarcity of timber, that some seven acres of forest trees, eighty years old, should be destroyed for a single day's issue of a New York paper. 


\section{CHAPTER IX.}

SEAWEEDS AND THE WATER-FLORA.

THE surface of the earth is generally covered by a nearly continuous green carpet of vegetation, which differs greatly in character according to the soil, and to exposure. This green covering is even continued through fresh or salt water; for the vegetation simply alters its character as soon as it is influenced by moisture; and a new flora appears, which extends through and under the water, rendering the barren waves anything but lifeless and useless in the world's economy.

This water-flora may be divided for convenience into three groups. (I) The Plankton, the free swimming or floating vegetation which occupies the surface, and goes down to a depth of 2-3 metres. As a rule the Plankton consists of very minute Algae or Seaweeds, which are only visible with a microscope; but sometimes there are also large Seaweeds, such as Sargasso Weed, or flowering plants like the Duckweed (Lemna), and the Florida Hyacinth. (2) The plants which cover the bottom of fresh-water lochs, rivers, and streams, and others which form the submerged flora of the coast-line, and are attached to the rocks, shingle, or other soils below the sea. These also are chiefly Seaweeds or Algae. (3) The transitional series, which includes many plants found in marshes, on mud, and by the seaside. These 
generally form a series of belts along the margin of the coast or of freshwater, and occupy the ground between open water and ordinary dry ground.

The Plankton.-The free floating vegetation or Plankton is compcsed chiefly of minute one-celled Algae, or Seaweeds. They generally belong to either the Diatoms or the Peridineae, and show very curious modifications for protecting thernselves against their minute enemies. The total amount of these minute vegetable forms, and of the animals which feed upon them, varies greatly. The plankton of freshwater lochs, and especially of little bays or backwaters in rivers with a slow current, is exceedingly abundant. It may amount to as much as $60 \mathrm{c.cm}$., or even to I I O c.cm. per cm., but varies very greatly according to the particular locality and according to the time of year. The amount of ozone in the water appears to have considerable influence in determining the health of the plankton. In Britain there are two distinct harvests of diatoms, one in spring and the other in autumn. These diatoms are one-cell organisms with brown chlorophyll bodies, and they possess a peculiar sort of cell wall. The original cellulose is covered by a deposit of flinty material, which takes the most extraordinary patterns, and is often ornamented by little lines or dots, or raised bosses, showing a bewildering variety of design. This flinty material forms two valves, which may be compared to a box and its lid. The lid overlaps the sides of the box. The mathematically exact patterns of their flint valves certainly resemble those of no other living cells. Sometimes the cells resemble a pill-box; but more often they are, in outline, cigar-shaped or oblong. They have been compared by Kerner to "little protected cruisers." A transparent mucilaginous 
matter covers the outside of the diatom. This is produced by a modification of the cellulose; and its oily or jelly-like nature diminishes friction with the water, so that the diatom moves readily in any direction. Occasionally, the diatoms become united in strings, which are held together by a common gelatinous coat (see below).

Diatoms multiply very rapidly. They do so, as a rule, by dividing in two, and each half forming a new diatom. They are said also to reproduce by conjugation, the living matter of two diatoms uniting to form an "egg" cell, which then grows and begins to form new diatoms by division. The "Kieselguhr" or diatomite of Skye, Barbadoes, and other places, is an accumulation of the flinty shells of diatoms. It is used for a variety of purposes ; for making fire-proof materials, for making dynamite, and in manufacturing artists' colours. The diatoms contain, when alive, drops of oil which may be regarded as a store of food material. It has been suggested that the shale oil, which is found in certain strata derived from deposits of mud, must have been originally formed by millions of diatoms. Though this is probably, to a certain extent, correct, no doubt both animal and vegetable life contributed to produce the oil. The free-swimming diatoms are not easily collected, but they may be obtained by dredging or trawling with fine muslin nets. The other group of one-cell Algae, the "Peridineae," is not so well known. They also have extraordinary ornaments of flint or calcium; but they appear in quantities only during certain months of the year. One of them, Pyrocystis, is phosphorescent, and glows when shaken or irritated by the waves.

These two groups of Algae supply the wants of most of the minute marine animals, which form the (B 7 ) 
food-supply of fish. In fresh water, many Algae belonging to different groups assist in forming the freefloating plankton. Of these the Desmids are especially remarkable for the beauty and variety of their shapes. They consist of a single cell, which is almost always

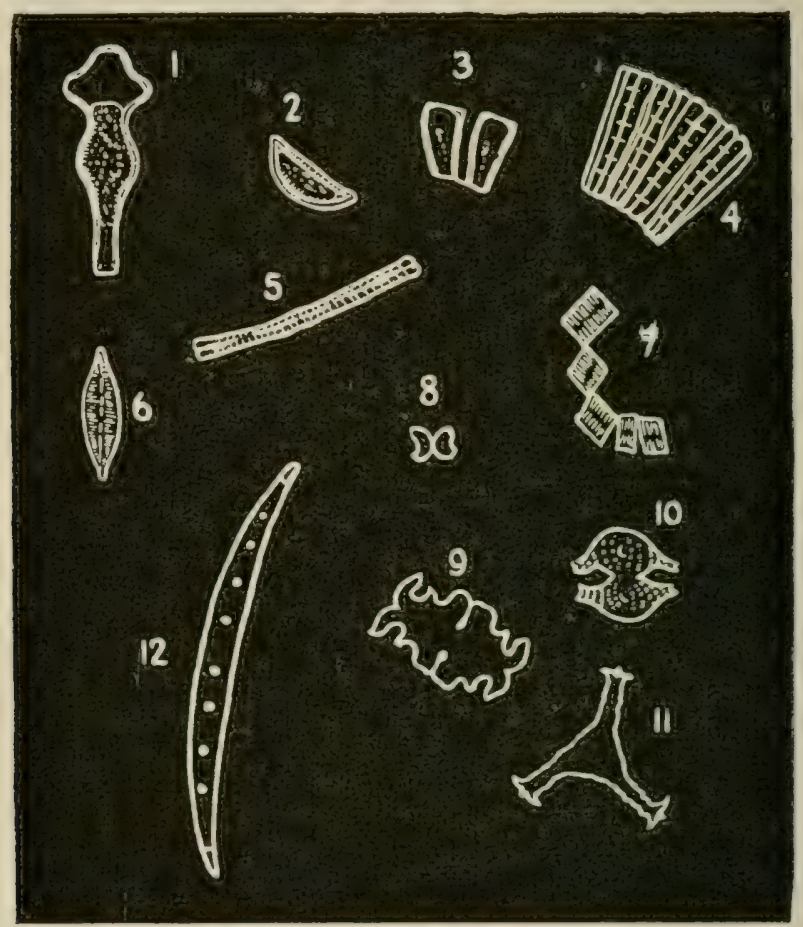

Fig. 23.-Diatonis (I-7) ANd Desmids (8-I2), (Diagrammatic.) (I) Gomphonema. (2) Cymbella. (3) Rhoicosphenia. (4) Meridion. (5) Synedra. (6) Navicula. (7) Tabellaria. (8) Micrasterias. (9) Euastrum. (I0 and II) Staurastrum spp. (12) Closterium.

divided transversely, by a contraction towards the middle, into two symmetrical parts or valves, and is cut into rosettes of fringed circles, or into wheel-like stars, often ornamented with tubercles, or reflex spines, or hairs. Desmids are generally of a brilliant and vivid green colour. Their shapes seem sometimes intended to assist in their floating, sometimes to keep them from being 
torn away by currents in the water. Some Desmids, when they are in danger of being carried away, are able to double themselves round, and hold on to any convenient support. They multiply like diatoms by a process of division, or by conjugation. Occasionally, two of these Desmids will unite to form a hard-walled spore or egg-cell, which, after a season of rest, grows and multiplies.

A very remarkable free-swimming Alga, Volvox, consists of a hollow sphere of cells, held together by transparent mucilage. Each cell has two thin whips, or cilia of protoplasm, and these, by vigorously lashing the water, make the colony revolve, so that it moves quickly through the water, tumbling over and over as it does so. The colony reminds one of the blastosphere of the animal world, but plants have not developed further than Volvox in this direction, for it is quite unlike any other Alga. In the sea, large free-swimming plants are not common; the Sargasso Weed which covers the Sargasso sea (Cystophyllum or Sargassum) is a brown Alga. It is remarkable for the small buoys or bladders which assist in keeping it floating. A few Ferns, such as Salizinia, or Liverworts (Riccia), and some flowering plants, are also quite independent of the earth, and float on the surface of fresh-water lochs and rivers. The curious little Duckweed (Lemna) has two minute fleshy fronds about a quarter of an inch long, with hanging roots attached to them. This plant occurs in almost every pond. The Water-soldier, Stratiotes, resembles a small lettuce head, and is especially abundant upon the Nile. The Florida Hyacinth, which occurs in the St. John's river and other places, floats by means of its swollen leaf stalks, which prevent it from being upset (see p. 57). 
Thus the plankton must be imagined as present, though invisible, both on the surface of every sea, loch, and river, and on that of the smallest puddle or rivulet, and it must be remembered that it extends to a depth of 8 or 9 feet. ${ }^{1}$ It is only polluted streams that are without Algae, and these are generally occupied by swarms of bacteria and fungi.

(2) The bottom and sides of lochs and the seashore are also generally covered by a dense vegetation, which extends to a depth of about 120 fathoms; it is unable to go deeper on account of the absorption of light by the upper layers of water.

On the seashore there are three well-marked zones of Algae. Near the shore, and only covered at high tide, are dense growths of green Algae, chiefly Enteromorpha and Vaucheria. Somewhat lower down the rocks and stones are closely covered by dark olivebrown kelps and tangles, of which most are species of Fucus. Still lower, and only uncovered at very low tides, are the Red Algae. These are generally small and delicate in appearance, and are often only to be obtained by dredging, or after severe storms, when they have been torn off, and are left stranded at high tide. This distribution depends entirely upon the light. The green species possess the ordinary chlorophyll found in land plants; the brown have to protect themselves against sunlight at low tide, and to suit themselves to totally different conditions when the water covers them. Hence they have a brown substance in addition. The red are found deep in the water where, apparently, only the dangerous blue rays of sunshine are able to penetrate, and hence they require a specially protective

\footnotetext{
${ }^{1}$ IIalosphacra viridis occurs at a depth of $200 \mathrm{~m}$. in the warmer parts of the Atlantic.
} 
red colouring matter. All, however, possess chlorophyll, as may easily be proved by soaking them in fresh water; when both the brown and red colours diffuse away, leaving the ordinary green chlorophyll. The particular species will vary very greatly according to the character of the shore. Hard rocks, which do not weather easily, often show the richest variety. Mud is generally only occupied by the rich deep-green carpets of Vaucheria, or by webs of yellow-brown Ectocarpus. Shingle and sand, or continually shifting mudbanks, afford no hold to the larger Algae, but when they are allowed to remain at rest they soon become covered. They are probably first attacked by crusts of diatoms; then the Ectocarpi or Vaucherias on mud, and the Enteromorphas on sand, begin to cover them. Stones which are not disturbed, soon become a dark purple-red, or rich olive-brown colour. No one would suppose this stain to be the result of vegetable life, but by carefully scraping the stone and examining it microscopically, it is easy to see that there is a crust of algal cells covering it. There are, in fact, some 16 genera and 20-30 species of Algae, which are specialised to cover rocks and stones. In some, such as Hildenbrandtia and Petrocelis, the cells are arranged in parallel vertical rows, and are closely held together by mucilage. In others, they are arranged in radiating lines, and are easily visible, as reddish or olive-black gelatinous excretions on the stones.

The tenacity with which all Algae are able to maintain their position is very remarkable; a Vaucheria carpet is very common on the estuarine mud of the Clyde, and it has been found that a depth of nearly an inch of mud is entangled in the Algae; a foot square with the mud attached can be supported by one corner 
without the algal threads breaking. The large Laminarias and Alarias cling very firmly to the stones and rocks by their peculiar root-like bases. It is not unusual to find a small piece of rock or stone which, although it has been broken off by the waves and has been washed to and fro in the water, is still attached to a Laminaria; and what is even more extraordinary, to find very delicate forms, for instance, a group of diatoms which have been attached by thin almost transparent gelatinous threads to a ship's bottom, and carried with it through storms and at high speeds. Even the slender Polysiphonias, growing on rocks exposed to the full force of the winter storms, are seldom broken off. It seems incredible that so weak an attachment could possibly hold them in position. Of course, as the entire surfaces of all Algae are oily and smooth, through mucilaginous changes of the cellulose, there will be but little friction with the water, yet this is by no means a full explanation.

It is, of course, quite impossible to describe the vast group of Algae. Reference must be made to Dr. Murray's work, or to Harvey's Phycologia Britannica. The way in which the simple, solitary cells of such forms as Pleurococcus have become specialised and been made part of a complex solid body, such as Laminaria or Fucus, can be understood from examining a series of different species. In Spirogyra the cells form a row or filament attached by a clasping cell at the base. Then in Enteromorpha, the cells are combined into a single layer or plane surface, which is sometimes arranged in a cylinder. In such a form as Cladophora or Ectocarpus, the rows of single cells are combined into a sort of branching shrub. In Polysiphonia, the transverse section of the stem is made up of a circle of 
cells surrounding a central chain, and the stem has branches and special attaching cells. In the highest types, such as Fucus and Laminaria, there are bodies of cells. Those cells which form the skin are small and full of chlorophyll grains, whilst the cells become larger towards the inside of the frond, those in the centre being a lonse entangled network of long colourless cells, probably used to conduct the food material. There is, therefore, clearly a definite division of labour amongst the cells. Not only so, but in Fucus, Laminaria, and Rhodophyllum there are rootlike, stemlike, and leaflike organs. In the latter case, the leaves have an extraordinary resemblance to those of the dock.

Chara is even more remarkable, for here the upright stem with branches, leaves and apparent flowers, has a very distinct analogy to that of the higher plants.

It is this variety of shape and architectural plan, and the extraordinary differences of the reproductive organs, that give so much botanical importance to the whole group. They are certainly the lowest and least specialised of plants, and show attempts at development in many different directions, whilst the lines of ascent are more or less definitely determined in all the higher groups.

As regards the methods of reproduction, it is unnecessary to give many details, as this is very fully given in many English text-books. There are four distinct kinds of reproductive bodies and two methods of reproduction-Nonsexual and Sexual. Nonsexual reproduction of the simplest conceivable type occurs in Pleurococcus and Sphaerella, where the single cell divides into two new ones, which are in all respects similar to their parent. Obviously this is not distinguishable from ordinary growth. In the higher Algae, such as 
Ulothrix, the nonsexual cells produced for multiplication are specialised. They possess two lashes, or cilic, by which they can swim at a considerable speed. They eventually come to rest, and grow into a new Ulothrix. In the Red Algae the nonsexual spores occur in groups of four. They are specialised for colonising, being a darker red, probably full of reserve food material, and they are larger than the ordinary cells, but they have no swimming cilia.

The sexual spores are male and female. The male, or spermatozoid, is generally a very minute speck of nuclear matter with long lashes by which it swims actively in the water. The female spore is generally larger, and often contains much food material; it is not capable of motion as it has no swimming cilic. In these, the lowest types of life, therefore, the male is more active and enterprising than the female, and this difference persists through the whole vegetable and animal kingdom, with apparently very few exceptions.

The egg-cell resulting from the union of the male and female spores sometimes germinates directly; but, in many cases-in the Red Algae and in others-the fertilised egg begins to divide, and forms a quantity of spores each of which can grow into a new plant. In the Algae, therefore, there are male, female, and egg-cell spores in addition to the nonsexual forms. Dr. Scott gives an excellent account of Pelvetia and other types to which reference should be made.

The third division of the water flora consists of certain fringing transitional plants, which make their appearance whenever land vegetation is interrupted by a sheet of water. These plants sometimes cover large areas of mud or sand, or of marshy fenland. In Britain they are essentially transitional forms. 
The West Coast of Scotland, from the Clyde at Renfrew, southwards gives many examples of the most characteristic seaside vegetations in Britain. Near Dumbarton and Langbank, there are great stretches of estuarine mud where are to be found those plants intended by Nature to turn the alluvial silt into good fertile land. From Ardrossan to Ayr is a sand-dune country, which shows very distinctly the changes by which a stretch of barren and desolate sand hillocks may be reclaimed into ordinary meadow or woodland. However, perhaps the most interesting transitions are to be found on the sides of lochs and ponds, and, occasionally, along slow-moving rivers and canals. In these last cases particularly, it will be found that the green surface due to scattered living plants, continues without interruption through the marsh and under the water, so that, even at a depth of nine or ten feet, plants are actively engaged in utilising the light which filters down to them.

In Scotland lochsides often show the following regular succession of plants. Where the soil becomes water-logged, the ordinary clovers and grasses of the meadow become intermingled with such forms as Ramunculus fammula, and various sedges. This first fringe of marsh plants is followed by:-(2) Rushes often occupying a very narrow width; (3) Iris or Flag, usually where the water is less than eighteen inches deep; (4) Reeds such as Scirpus, or Equisetum limosum, generally occupying the water from a depth of two feet to four feet six inches; (5) Floating leaves of the Yellow and White Water-lily-the rhizomes of these plants are sometimes at a depth of nine feet six inches; ${ }^{1}(6)$ the Pondweed, Potanogeton natans;

1 These measurements were taken at Bearsden, near Glasgow. 
(7) Open water which, however, is full of floating Diatoms (Plankton), and under which there may be a sort of subaqueous meadow of the Alga, Chara, which is in France found to a depth of 36 feet. A similar general succession of Wet Meadow plants, Rush, Flag, Reeds, Water-lily, Pondweed and Plankton seems very common throughout Northern Europe. ${ }^{1}$

In each of these belts it is easy to note some of the more obvious adaptations of the plants to their particular position in the water. The whole series, from the Rushes downwards, including the Water-lily and Potamogeton, have a very characteristic texture. They cantain many air cavities which fulfil a double function : the oxygen required by the living cells for respiration or breathing is difficult to obtain in the case of waterplants, and so air fills the hollow spaces. The presence of the air-chambers also makes the plant buoyant and able to float freely. There are other easily distinguished characters of the water-flora, such as very little woody tissue or cork, and often no stomata.

The Reeds vary considerably, according to the slope of the pond or loch Where it is very steep, such forms as Equisetum limosum occur. If it is gradual, Phragmites communis is generally the most conspicuous form. This plant has extremely long runners, which may grow out towards the water for a length of 16 feet. From the main submerged stem a series of branches are given off at close intervals, and these latter curve upwards, and develop their leaves above the water. In some parts of the Danube valley, this plant covers an

${ }^{1}$ Warming describes an almost identical series in Scandinavia. In the Jura the order has been given (Magnin) as follows: (2) Sedges ; (3) Phragmites, that is, the Reed grass (see below); (4) Scirpus; (5) Yellow Waterlily (9-I5 feet depth water); (6) Potamogetons (12-24 feet); (7) Chara (24-36 feet). 


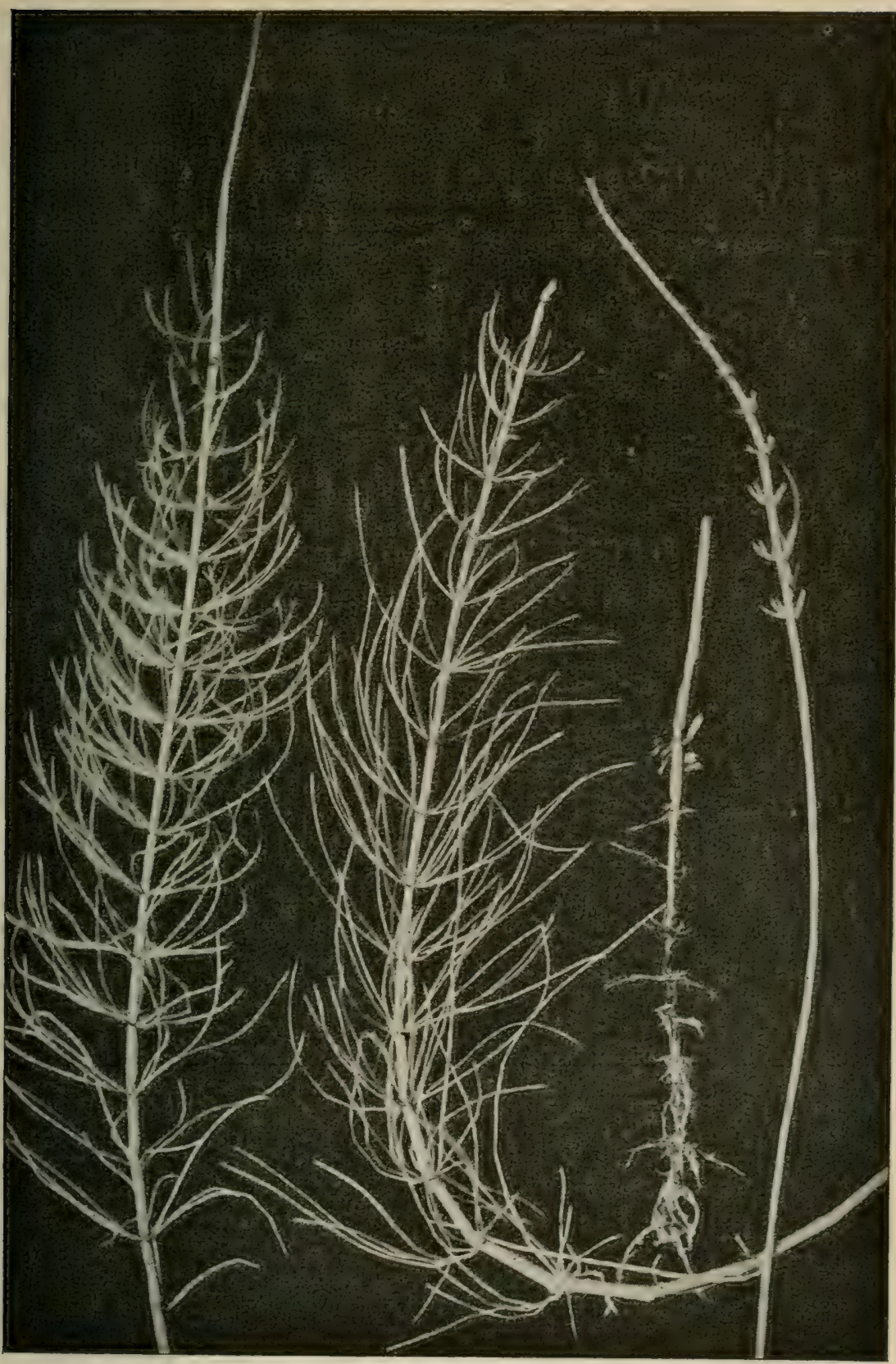

FIg. 24.-The Horsetall (Equisetum maximum). Specimen in the centre with a small flower. That to the left is a full-grown barren branch; part of the rhizome with roots and an undeveloped bud and an immature branch to the right. 
area of many square miles, and grows, in some cases, to a height of 18 feet. In the Clyde valley it is often I 3 feet high. It is clear that these submerged horizontal stems and branches will enable the Reedassociation to grow out into the pond. An arrangement of this kind is very necessary, on account of the way in which the water becomes filled up near the edge of the pond in the zones of the Iris and Rush.

In these, the tangle of plants is so great, that it is difficult at first to make out any distinct system; but close observation shows, that almost all the plants have something of the same way of growth as the Phragmites. The main stems grow horizontally, and the branches vertically. The former are either lying on the mud, like the Iris or Marestail, or perhaps floating submerged in the water, as in the cases of the Bogbean (Menyanthes trifoliata), and the tough horizontal stems, sometimes three feet long, of the Marsh Cinquefoil (Comarum palustre). The net result is a series of horizontal stems at different depths, and from these a sort of forest of upright branches, of which some carry, like Hippuris, submerged leaves, and others, like the Iris, hold their foliage entirely out of the water.

The Comarum leaves are generally in the air; but they are liable to be accidentally plunged below the water, and so they are specially protected against this danger. If a leaf is dipped in water, it will be covered by a beautiful silvery lustre (an air film), and, on withdrawal, it is found to be perfectly dry. There is a development of wax upon the leaf which prevents its being permanently wetted.

A clear idea of the forces at work in the tangle of plants near the margin, can only be obtained by the use of the imagination, supplemented and corrected by 
accurate observation. If one were to suppose oneself about an inch in height and standing on the mud amongst the reeds, the water would seem to be crowded with thick stems and branches. From the upright ones, graceful floating ribbons and streamers of green Algae would hang waving in the currents. Masses of jellylike Algae containing green or blue cells would be attached here and there. Every branch and stem, as well as the whole muddy floor, would be covered by a crust of golden-brown diatoms, forming a continuous and uninterrupted coating. Some would be attached to elegant stalks of transparent jelly; many would be dead and transparent, allowing their delicate lines and striae to be distinguished. Floating on the surface above would be little colonies of Lemna; and, perhaps, floating Algae, such as Oscillatoria. Even the water itself would be occupied by scattered, free floating diatoms, moving about with their peculiar screwing motion, as well as by an infinite variety of waterfleas, water shrimps, and other living creatures.

Moreover, the interlacing of upright and horizontal branches near the edge of the water forms a sort of trap for silt. Dead leaves and fallen branches, etc., collect in this entanglement, and the formation of organic matter proceeds rapidly. After a very few seasons, the mud has so risen that the water is sufficiently shallow for Rushes and Iris to develop. Then their leaves and the floating silt, etc., will give sufficient foothold for the marsh plants and these will eventually give place to the ordinary land vegetation.

Canals and rivers often show, in backwaters and in very gently flowing parts of their course, the same general succession; but, sometimes, special plants are to be found in these backwaters. Thus, for example, the little bays 
above the locks on the Forth and Clyde Canal very often contain floating stems of Poa fuitans. Sometimes these stems extend three feet or more out from the bank, and many Spirogyras and other Algae are attached to them. These plants also entangle floating material of all kinds, so that the shoreward side becomes sufficiently firm to support mud-plants and even such grasses as Poa anmua. About three feet of land may in this manner be added to the banks, and hence a continual clearing of the canal becomes necessary. The hardiest of these water-plants and the most objectionable from a fisherman's point of view is Elodea Canadensis. This multiplies so rapidly that it seems able to choke out everything else; and it often fills shallow ponds with a dense mass of vegetation.

Other characteristic water-plants occur, especially in summer, in small streams and in shallow rivers, or in those of a moderate depth. The various forms of Ranunculus aquatilis and of Potamogeton must be mentioned, as it is possible to trace in them regular modifications, adapting them to the rapidity or slowness of the current in which they are found. The more rapid the current the longer and the finer divided the leaves. When the Ranunculus is able to do so, it forms undivided air leaves supported above the water.

The reader will find that anyone of the marsh or water plants which he studies in the field shows many other interesting adaptations to its position. The reproduction of these fresh-water plants is also peculiar. Some of them have special arrangements for seeddistribution. The Water-lily, for instance, has seeds which are able to float, and which are also eaten and probably scattered by water hens. Veronica Beccabunga, whose long trailing stems occur chiefly in very small 
streams, only opens its capsules in very wet weather; and the seeds have a gummy secretion on the seed-coat, by which they probably stick to the feathers of water birds. Many water plants produce special buds before winter, which are packed with starch or food material. These drop off into the mud, and next year grow up into new plants.

The seashore is just as interesting as the margins of lochs and rivers, but the life conditions are much more complex, and they have not by any means been fully investigated.

There may be either (I) rocks, (2) shingle, (3) sand, or (4) mud extending seawards from the edge of the ordinary land vegetation. Each of these soils has its own especial and peculiar series of plants, occupying the space between the ordinary grasses or other vegetation and deep water. In every case, they tend to choke themselves out by the accumulation of organic matter which they produce, and are pushed further and further seaward by the pressure of the advancing land vegetation. As the sea often washes away the land, and as estuarine rivers often eat into the banks, obliterating the marks of succession, the exact succession is very difficult to trace, and is often obscured altogether.

ROCK FLORA.-Seaside rocks generally show a very clear line, or division of plant life. Those parts which are submerged at high tide are densely occupied by Fucus, and sometimes by green Cladophoras and Enteromorphas. Above high water mark, there is a regular rock-flora, which, however, differs from the ordinary type of rock-flora in the presence of characteristic lichens, mosses, and flowering plants. The transitional plants are mainly Algae and show the succession given above. 
SHINGLE FLORA.-Occasionally along the shore great accumulations of shingle may be found. These are continually shifting, either with a distinct set in one direction, or backwards and forwards. Very few plants seem able to exist upon the stones unless they have been a very long time at rest and have been covered with a certain amount of soil. Amongst the most characteristic colonisers of shingle are Rosa spinosissima, Potentilla anserina, and a few others. Brassica monensis also generally occurs in shingle or gravelly soil mixed with sand. In Scotland special adaptations to this unusual form of the coast have not been traced.

SAND FLORA. - This is also distinctly the case with regard to the next group, or sand-dune plants. On the seaward side of the dunes, which is generally at a very slight slope, will be found the Sea Couchgrass (Agropyrum) and Honckeny'a peploides. Both have exceedingly long underground stems which are capable of developing under the most unfavourable circumstances, and both are well adapted to the salt, barren, and exposed positions in which they grow. Upon the seaward face of the dune, and upon all the freshly formed hillocks, only the Dune Grass (Ammophila amudinacea) seems able to develop. The strong stems of this plant are often many feet in length; its very hard, sharp buds help it to bore a way upwards through several feet of sand. Hence it is difficult for the shifting sand waves to overwhelm it. When the dune has acquired a certain stability through these tough interlacing rhizomes, other plants begin to appear. Generally, these are to be found on the summit of the dune a little way back from the exposed face. Eryngium is one of the first to occur, then Festuca ovina becrins to occupy most of the spaces left between the 
tufts of Ammophila. Still further from the sea, Lotus corniculatus, Vetch, Potentilla anserina, and many small herbaceous plants are able to fix themselves. A great number of mosses Hypmum cuspidatum, H. squarrosum, species of Hylocomium and Liverworts, form dense tufts between the other plants, or in some places crusts of Cladonia and other lichens cover the sand. The change, however, generally ends in the production of the peculiar "golfing" turf, only found in perfection near the seaside. At Southbourne (England) the herbaceous plants are not the same as those that are found on the sands in Ayrshire. Both Viola camina and Jasione montane are remarkably common, and Furze or Whin, Heather, and even Pine trees, seem able to occupy the sand dunes, as soon as they have become definitely fixed. It is of course well known that in France, the great damage caused by blown sand and wandering dunes has been prevented by artificial planting with Pine trees. Even in Ayrshire, Pinewoods occur in country which seems to have been at one time pure sand hills. At present, every stage can be traced between the ordinary arable land or pasture and the sand only covered by tussocks of Ammophila.

MUD-FLORA.-The conditions when mud or flat sandy soil forms the coastline are exceedingly complex and difficult. There are $(\alpha)$ Submerged Seagrasses which occupy the shifting banks of mud and sand, and are only visible at low water. (b) Muddy Flats and gentle slopes only covered at high water and colonised by the Cochlearia or Scurvy-Grass-Association. (c) Lagoons and deeper places near the shore, however formed, inhabited by the Estuarine Reeds. The Seagrasses occupy the deeper water, and there is probably a distinct series of forms leading from $(b)$ and $(c)$ to them; but it is not 
possible here to give a very satisfactory account of the succession.

The Seagrass (Zoster $a$ ) covers hundreds of acres at Hunterston Point on the Clyde, and must be considered as perhaps the most important of all these land-forming plants; for it is the Zostera which is probably the first to fix definitely the mudbanks of navigable rivers, though the important practical questions which arise from this fact are not yet answered. It extends to a depth of 36 or even 42 feet, and forms a sort of submarine meadow; the leaves are long and like those of grasses, and are said to become much broader at great depths; the rhizomes from which they spring form a sort of interlacing entanglement on the mud, and occur in great quantity.

Another plant, Ruppia, which is abundant at Cardross upon the Clyde, occurs nearer the shore generally from a little below high-water mark to a considerable depth. It has a creeping stem or rhizome of a very peculiar appearance. 'There are generally from three to four internodes (about half an inch long) of which the two or three oldest are completely buried in the mud; this covered part curves downwards so as to lie below the small exposed portion. A root 3-4 inches long is given off at every node. The internodes of the stem are not in line with one another, but zigzag alternately to right and left, and the roots therefore slant downwards also to right and left. The peculiar anchorlike curve of the stem, tied down by these relatively long roots, will offer a very strong resistance to the uprooting effect of the currents. One long, thin and grasslike leaf is also given off from each node.

The mud-flora is especially characterised by such plants as Cochlearia, Plantago maritima, Aster Tri- 
polium, in some places the common Thrift (Ammeria vulgaris) and others. On the shoreside this vegetation is always being encroached upon by the regular seaside turf, or by cultivation. Towards the water, these mudplants become more and more distant from one another, until they finally disappear about, or a little below, the level of high tide, just above the Ruppia zone.

The most interesting point about these mud plants lies in their being apparently adapted to dry conditions, in spite of their living usually in places where there is abundance of water. Many possess fleshy leaves, and some, such as Cochlearia, occur also on the tops of mountains, where, at first sight, it would seem as if the conditions were totally different.

The following is the explanation of the phenomenon generally given. It is known that if ordinary plants, such as the Daisy, are watered with salt water, the leaves become more fleshy and succulent than usual. The salt is a poison to vegetable protoplasm; and it is obvious that plants that grow near salt water should diminish the amount of water they absorb as much as possible, so that as little salt as possible should enter their system. In this way the plants growing on the margin of the sea acquire their peculiarly fleshy leaves and their resemblance to dry climate plants.

Many of these mud plants are very strongly attached by thick and branching roots. This is necessary, because they are often exposed to the full scouring action of high tides. In places where the land is being washed away, they may be seen invading the domain of the ordinary grasses, and other associations which are in process of being killed out by the salt water. At a lower level than the Cochlearias (sometimes also between them), recently deposited mud 
becomes very quickly covered over by the Alga, Vaucheria (alluded to above, p. I \& I). It forms a tough and flexible carpet, well adapted to fix the loose soil, and has a beautiful velvety dark-green colour. There are many marine worms and other creatures in these Vaucheria cushions. The estuarine Chenopodiaceae, and especially Salicornic herbacea, should be looked for about or a little below this level. Below this again is the habitat of Ruppia, and, still lower, of Zostera.

The formation of small creeks is very common in mud-flats. Fresh-water streams also cut out little deltas or deep channels. Sometimes also the banks of a tidal river will slope downwards, away from the stream, forming miniature lagoons or marshy places. The tide enters all these depressions, and it is in them that Reeds appear to flourish. These are to be found in bays partly sheltered from the scour of the current, and with a depth of perhaps 6-I 2 inches of water at high tide. The dominant plant of these reed beds upon the Clyde is Scirpus lacustris var. Tabernaemontani; it gives off horizontal runners about nine inches long, which fix themselves firmly in the mud by several roots. Each fixed point is a new base for the production of fresh runners and foliage branches. In such a bed, between forty and fifty vertical stems may be counted upon a square foot of soil. As the leaves wither and die, they are entangled amongst the vertical stalks, which last through the winter in a withered condition. Anything floating in the water, such as cotton rags, dead leaves, silt, and refuse of all kinds, becomes entangled, and is retained amongst the stems. Ectocarpus crinitus and other Algae also develop between them. Hence the level of the soil gradually rises; and very soon the landward side begins to be peopled by 
other forms. First, the mud plants, such as an odd specimen of Cochlearia, of Aster Tripolium, of Agrostis alba, or a few plants of Iris, and, finally, the common Rush and the regular meadow grasses.

Several other Cyperaceae act somewhat in the same manner, but they are not of so much importance. Scirpus mufus has a particularly neat system of horizontally creeping runners extending seawards. Both this and S. lacustris, as well as the fresh-water reeds, obviously render the soil unsuitable for themselves by their own growth, and they are essentially pioneers preparing or "winning" new land for the ordinary grasses. In all estuarine and alluvial land, vegetation of this kind has played a very important part in physical geography, although it seems to have escaped the notice of most geographers. It is upon such alluvial flats that the greatest part of the world's population is maintained, as is easily seen by referring to such cases as the Rhine, the Thames, the Yangtsekiang, the Nile, the Ganges, and the Clyde. Surely, therefore, these estuarine plants deserve a more thorough examination than they have yet received. 


\section{CHAPTER X.}

MICROBES, MOULDS, AND YEAST.

TiIE surface of the earth, and, especially, the upper layers of the soil may be considered as the chief storehouse of bacteria or microbes. They seem always present in air, but are least numerous after heavy rain. Even at I 0,000 feet altitude in Mexico, Dr. Weinzierl found a ten minutes' exposure to the air produced colonies of bacteria on his gelatine plates. They are found almost everywhere, in water; on the surface of plants; on the petals of flowers; on coins and banknotes; upon the skin of animals; even on the lips of human beings. Some of them are comparatively harmless; some are, indeed, very useful ; but, on the other hand, a few are capable of decimating a continent when given an opportunity to do so. Not only is this the case, but animals carry about within their bodies germs of many different kinds. Some of these seem absolutely essential to animal life. Digestion, for instance, is probably carried on by the help of Sarcina ventriculi; and it is said that animals fed on sterilised food invariably die in a short time.

The soil bacteria are of very great importance in agriculture. Some of these minute plants break up or decompose the bodies of animals and of plants, and so render the waste products available. Even those bacteria most dangerous to man have their importance, because 
they keep the human species up to a proper standard by destroying the unfit.

The number of bacteria varies according to the situation and character of the soil itself. A cubic centimetre of arable land will contain from 2-I 5 millions of bacteria and an ounce of roadside dust will probably contain some 50 millions. Bacteria have been found

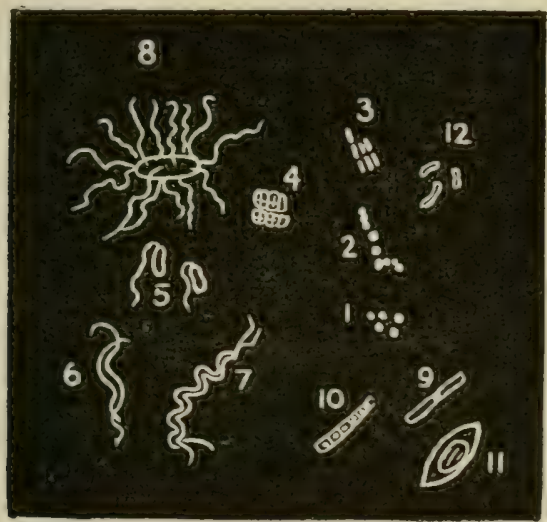

Fig. 25.-Bacteria. (1) Micrococcus. (2) Streptococcus. (3) Bacterium.

(4) Sarcina. (5) Pseudomonas. (6) Bacillus. (7) Spirillum. (8) Bacillus.

(9) Spore of B. subtilis. (ro) Spore of B. megatorium. (II) Clostridium.

even at a depth of 50 centimetres (nearly 20 inches) below the surface. Water contaminated by sewage is full of bacterial germs. No less than 49 distinct species have been extracted from London sewage water. Cream left standing for 36 hours may develop $485,000,000$ bacteria per cubic centimetre.

Bacteria are a distinct group of Fungi easily recognised by their exceedingly minute size and characteristic appearance. The name Schizomycetes (division fungi) is derived from one of their most distinctive characteristics. They are one-cell plants and multiply by division. Each cell divides into two daughter cells; and these very soon become mature bacteria capable of dividing 
again. In some cases the division will take place in 20 minutes after the individual has been formed; so that, if circumstances are favourable, a single germ may have 16 million descendants in eight hours. They are exceedingly minute; it is said that $250,000,000$ of the Bubonic Plague germ can exist on a square inch of garden soil. Generally their size varies from .2 to .1 5 micromillimetres.

The shape varies; but only within fairly definite limits. Most of them have no power of locomotion, but many are able to move actively about by means of exceedingly thin hairs, or whips, with which they lash the water or other liquid. The most important kinds are the following :

CIRCULAR OR ROUND FORMS : Streptococcus, dividing in only one direction; Micrococcus, dividing in two directions; and Sarcina, dividing in three directions so as to form peculiar oblong parcels.

ROD-LIKE OR STICK-LIKE FORMS: Bacterium motionless: Bacillus moving or swimming by scattered threads attached all over the surface, and Pseudomonas, which swim by lashes attached at one end.

CURved OR CORKSCREW-SHAPED FORMS: Mikrospira, moving by I-3 polar lashes; Spirillum, with 5 to 20 lashes at one end, and Spirochaete, which wriggles or bends about like a snake. How this last is able to move does not seem to be understood.

THREAD-LIKE FORMS: such as Crenothrix, and finally Sulphur bacteria (Beggiatoa).

The cells are very small, and generally almost transparent. No nucleus similar to that found in the higher plants has as yet been discovered; and, though it is always possible that they possess one, it seems very improbable that they do so. Some forms are capable 
of producing spores, but in the majority of cases spores do not occur. These bacterium "spores" are quite different also from the spores of other plants. They are really resting states, and are formed in a peculiar and unusual way. The protoplasm of a cell changes in appearance and becomes of a finely granular character. A small denser part appears in the centre, and gradually enlarges till it absorbs the protoplasm and becomes the spore. This lies inside the membrane or wall of the original cell, but possesses a distinct wall of its own. It is not difficult to get the spores of Bacillus subtilis. It is only necessary to keep the yeast (see below, p. 2 I 5) long enough upon the plaster of Paris, and they are pretty sure to be attacked by Bacillus subtilis, which will form spores.

The cell wall is very seldom visible, and it is only distinct in spore formation. The wall is probably of quite a different kind to that found in other plants. The resistance of bacteria to extremes of temperature is very remarkable, and the spores are even more resistant than the ordinary cells. Certain bacteria (Typhus, Colicommunis, and Diphtheria) withstood a cold of $-182^{\circ}$ to $-192^{\circ} \mathrm{C}$. for twenty hours. No less than 44 organisms in one experiment survived exposure to a cold of $-210^{\circ} \mathrm{C}$. Certain spores of bacteria can stand a heat of $150^{\circ} \mathrm{C}$. without destruction. Even sudden and violent changes do not always kill bacteria. If milk, for instance, is quickly heated to $70^{\circ} \mathrm{C}$., and then rapidly cooled in ice water, only some 90 per cent. of the bacteria die; it is necessary to wait and allow the spores to germinate, and then repeat the experiment.

On the other hand, germs are very susceptible to sunshine. Only four hours of sunshine are sufficient 
to destroy cholera vibrios, or at any rate to make them harmless.

They are easily killed by many kinds of poison. Thus a solution of 35 per cent. alcohol will kill off all bacteria which are likely to be found on glass vessels or upon instruments. A very small percentage of corrosive sublimate is also a bactericide of great value. The oils of Eucalyptus and Cinnamon, and the active principles of Thyme, Turpentine, Lemon, Lavender, and similar substances, are deadly to bacteria. Air filled with the vapour of oil of Lavender has killed the typhus bacillus in twelve hours, and the vapour of oil of cinnamon is even stronger; for when it was used the bacteria were destroyed in forty-five minutes. Such perfumes and spices are in all probability formed by plants for defensive purposes. In the case of many antiseptic preparations man simply uses for his own ends the protection devised by plants for themselves.

The functions of bacteria are so varied that it is difficult to classify their work in any convenient way. We will begin however with those found in the soil, and, after mentioning a few which are of great agricultural importance, describe those which produce infectious diseases and are utilised in the disposal of refuse matter.

Of the Soil Bacteria, one group absorb the free nitrogen in the air and turn it into nitrates which can, of course, enter plants and be used in building up vegetable tissues. In one experiment, two sets of vessels were filled with earth which had been sterilised, or rendered free from Bacteria. Cabbage plants were grown in each set, but one series was inoculated with these soil bacteria, and the other was not infected.

In every case the Cabbages were heavier and had 
more seeds, if bacteria had been introduced. Another observer gives the actual amount of nitrogen gained by the bacteria. After twenty days' growth in a special solution ( $500 \mathrm{ccm}$. of liquid), one form, Clostridium, had been able to obtain 28.87 milligrams of free nitrogen. The nitrate deposits found in South America are, probably, due to Bacteria.

These nitrogen-gathering bacteria (B. 5, p. I 28) belong to several species and no doubt there is often a sort of co-operation amongst them. Sometimes, they may be assisted by other plants, such as Algae and Mosses, but this has not been clearly proved. In other cases, the bacteria act in a reverse way, as one would expect (see diagram on p. I 28 ); for the atmosphere could not remain unchanged, if nitrogen were always being taken from it and none returned. These other soil bacteria, B. 4, change nitrates into free Nitrogen. They are specially abundant where oxygen is kept out, as, for instance, in manure heaps which have been kept too long. Races of bacteria soon develop in such heaps, and work upon the decaying material, turning the nitrogen compounds into free nitrogen. As manure is often stored for six months, this means a serious loss to the farmer. It has been calculated that, in Germany alone, $£_{\mathrm{I}} 5,000,000$ worth of nitrates is lost every year by delay in using the manure.

When waste products are spread upon the fields, they are attacked by quite a different series of forms; some are very beneficial, as they break up the nitrogenous bodies first into nitrites, B. 2, and then into nitrates, B. I. These nitrates enter the plant, and, if the plant is afterwards eaten by an animal, these nitrogenous substances are utilised in the animal's body. All decaying vegetable and animal substances, such as 
dead leaves, insects, the bodies of animals, etc., are broken up in the same way by bacteria, B. 3, and their nitrogenous parts again used by plants.

Amongst the most interesting members of this group of bacteria, are certain kinds which inhabit peculiar little tubercles on the roots of Clovers, of Whin, and of nearly all plants belonging to the Leguminosae. These, B. 6, belong to the set which obtain nitrogen from the air. On account of the Leguminosae being specially endowed with these nitrate-forming bacteria, their agricultural uses are very important. A crop of Leguminous plants increases the amount of nitrate in the soil; and, in Germany, these plants are often grown, not for seed or fodder, but merely to be ploughed into the soil whilst still green. By this means the soil is enriched with nitrogenous material, and produces a larger amount of more valuable crops, such as Cereals or Beetroot. It will thus be seen with regard to bacteria: (I) that they lie, literally, at the roots of all plant life, and are probably essential to it; (2) that they have produced the nitrate deposits of South America; (3) that they are of extreme importance in the rotting of farmyard manure and of all decaying matter; (4) that they are specially important for Leguminosae.

But they are also essential in the following common operations in agriculture: (a) Haymaking, during which bacteria destroy the more perishable parts of the grass leaves and stems. The difficulty in a wet climate lies in the tendency of the putrefaction-bacteria and moulds to develop within the heaps. This results in decomposition, or even in spontaneous combustion, if the hay is stored in a wet condition. The heat within a stack is often $70^{\circ} \mathrm{C}$. (b) Ensilage or Silos: Grasses and Herbaceous plants are collected when green, and 
dried under pressure in specially built silos. The decomposition is carried on to a certain point by bacteria, and stopped before decay takes place. Salt is used with the grass, and the result is a brown, pleasant-smelling substance of which cattle are very fond. (c) The souring of milk: This is due to the bacteria of lactic acid fermentation acting on the sugar of the milk. The lactic acid so formed is, however, necessary for the coagulation of casein, which is essential in butter-making. (d) Another bacterium produces the butyric acid fermentation, which has the effect of destroying both butter and other food materials. This same species is, however, necessary for the formation of cheese. (e) The mamufacture of leather: This is a very complex process, depending for its success on two different processes, both of which are connected with bacteria. The hide, as brought to the tannery, contains many very perishable substances, which putrefy easily, and would very soon rot, and destroy the firmer and stronger material which becomes leather. By operations of a peculiarly horrible nature, bacteria are made to destroy all these perishable matters as quickly as possible. After this, the hides are saturated with tannin substance, such as extracts of the bark of oak, wattle, sumach, or other tannins. These astringent "tannins" are strong antiseptics, and the leather is kept from bacterial decay by their action.

There are so many other commercial and agricultural processes which depend upon bacteria, that it is impossible even to mention more than a few. (I) Linen Mamufacture: The separation of the tough fibre of flax bark from the softer cortex is carried out by the assistance of certain special bacteria, which "rett" the bark. (2) The common and important dye, 
indigo, is obtained from the leaves and young stems of the indigo by a sort of fermentation process, almost certainly due to bacteria. (3) The characteristic qualities of tobaco are only developed in the leaf by the action of bacteria, whose exact function is not known. (4) The manufacture of china involves getting the help of bacteria, as the change from kaolin to porcelain is assisted by them. (5) The necessity of creosoting, or tarring, timber, especially if it is to be placed in the soil, only arises because of the bacteria and other fungi, which would otherwise soon attack and destroy the dead wood. (6) Wine, Beer, etc., are kept corked and have to be very carefully manufactured on account of the ever-present danger of bacterial infection. (7) Bacteria have also been used by man for the purification of sewage. They swarm in this material. London sewage contains at least 49 distinct species, and they are present in all sewage in enormous numbers.

A short summary may be given of the system of purification adopted. The liquid is passed into a large tank or series of tanks and allowed to settle. During this stage of purification, bacteria, which are unable to exist in oxygen, act upon the material forming nitrites and removing about 53 per cent. of the impurities. The liquid then leaves this settling tank and is passed through an accumulation of coarse large-sized coke fragments or "cokebrecae." These pieces are covered by a film of bacterial colonies, and the bacteria manufacture nitrates from the passing sewage and so remove a further 29 per cent. of the impurities. It is not possible to keep the colonies continually at work, as they must be allowed to rest, and to recover from their labours. Hence a double set or shift of these last coke beds is required. It will 
be seen, therefore, that about 82 per cent. of the impurities are thus removed; the resulting liquid has no offensive odour, and is, in fact, so pure that fish can be preserved in it.

It is, however, those bacteria which cause infectious diseases that are the most generally known and have been most carefully studied. Many kinds of bacteria, as has been said, are constant inhabitants of the body of man and other animals. Some of them are quite harmless ; a few of them, such as the Sarcina and some of the many bacterial forms found upon the teeth, may be of great importance, and even of real assistance. Many others, however, are exceedingly harmful, and are the cause of a great number of infectious or other diseases, from toothache to typhoid.

The human body contains a number of free wandering cells, the Phagocytes. It is the function of these cells to enclose or surround bacteria with their own bodies and to digest them. If, however, the patient is unable to produce a sufficient number of these defending phagocytes to check the increase of the disease bacteria, these latter multiply to such an extent, that the whole system is thrown into disorder. In the body, the bacteria not only devour valuable substances, that is, substances the presence of which is necessary to health; but they also excrete into the body their own waste matters; and these may be of a poisonous nature, poisonous even to themselves. Inoculation, which is now adopted as a preventive against many diseases, depends upon the possibility of cultivating bacteria of any kind in a pure condition, and under human control. With proper precautions a colony of any sort (say "Fowl-cholera") may be isolated, and grown, in a testtube on sterilised (i.e. bacterium free) gelatine, or on other 
material. This colony is then weakened in constitution by bad treatment of some kind. It is exposed to temperatures which do not suit it, or it is made to develop on substances which do not agree with it. The result is, that each bacterium of the colony is less vigorous and virulent than the original type. If a chicken is inoculated with this weak type of the bacterium, it will develop probably only a mild form of the disease. Yet even these weak germs will probably devour all the food which is taken by the chicken-cholera bacterium, and they will pollute the body of the chicken with their excretions. If after this the chicken is accidentally infected by the original wild type, the latter cannot develop, because there is no nourishment in the body of the chicken for it, and because the excretions of the previous forms, already in the body, are poisonous to it. The whole of the theory and the methods of bacteriology are quite modern, and already the result has been an extraordinary diminution of human suffering. Thus of I 465 persons treated by Pasteur for Hydrophobia or Rabies, only four died.

It is, however, also possible to make Bacteria by cultivation twenty times more deadly than they are in nature (Bullock).

Plants also have their bacterial diseases such as the slime flux of trees and another which attacks the Hyacinth. This has been denied by some authorities, but has recently been abundantly confirmed by many experiments. The distinction between the disease forms and those which are found in decaying material sometimes breaks down. Thus B. colicommunis, which generally lives on dead matter, may become parasitic and produce a disease in living potatoes.

A very simple example will make it manifest that 
the importance of bacteria to mankind is very great. Grass and Clover pastures would be impossible without the bacteria of clover, those of farmyard manure, and those of putrefaction. The cow, feeding on these pastures, is probably assisted by bacteria to digest its food. The change of the cow's milk to butter and cheese depends upon the action of bacteria. It would be impossible to turn hides into leather without the aid of bacteria. The preservation of meat involves a complete study of them. Most of the diseases which attack cattle are also due to them. If the cow should be cut, or bruised, it is advisable to tar the wound, or treat it antiseptically. Most of these antiseptics, such as tar, pitch, resin, have probably been called into existence chiefly, because plants had to protect themselves against the spores of fungi and bacteria.

A very simple case will show how remarkably deficient even careful and well-educated people may be in scientinic imagination, and what serious evils may arise from the want of that faculty. A doctor ordered the destruction of the bedding of a patient who had been suffering from an infectious disease. The sickroom happened to be on the top flat of a tenement. The bedding was pulled down the common stair, touching every step on the way, then carted out through the street, and burned in a waste place. Thus the air of the staircase and of the street, not to speak of the people passing, were abundantly supplied with active and vigorous germs of disease. Far more, in fact, were distributed by treating the bedding in this way than if it had been left in its place.

Bacteriology is a study in itself, and the methods of sterilisation, etc., can only be learned in a laboratory. It is, however, not difficult to obtain bacteria for [( B 7) 
examination under the microscope. Thus, scraping the teeth with the end of a pencil will furnish a whitish matter consisting chiefly of bacteria. A section of the tubercles on clover roots, or a little cream left standing for a day or two, will also show an abundance of bacteria.

Both Moulds and Yeasts belong to the Fungi. Their action is, in many respects, very similar to that of Bacteria.

The spores of the Moulds Penicillium, Mucor, and Aspergillus are exceedingly abundant in the air, and are also capable of resisting great extremes of temperature. These fungi, however, differ from bacteria in consisting, not of single cells, but of long branching threads which grow in every direction through the liquid matter, or over the soil, upon which they are living. They produce spores in extraordinary abundance. To obtain these moulds, it is only necessary to put into a saucer a little jam, fruit, or bread in water, and to cover it with a tumbler. A white, greenish, or brown mould will very soon develop, and will overspread the whole of the material. It is only necessary to pick out a little of this substance, and to examine it in water under the microscope, to get a clear idea of the abundance of the conidia or spores.

They are produced on little upright stalks, which will ensure the spores being caught and carried off by slight currents of air. The three commonest fungus forms are Mucor, Penicilizum, and Eurotium. These moulds break up vegetable and animal matter. A spore germinates in a fruit solution, and grows out into long branching threads, which explore the solution in every direction. The fungus lives upon the sugars and other matters, and breaks them up, producing carbonic 
acid $\S_{3} 3$, and water. The threads or hyphae secrete a fermeni, which decomposes the sugar. Those moulds which grow upon plant tissues, such as dead leaves and stems, are able to break up even the cell-walls, or cellulose. They give out a special ferment, or cellulose

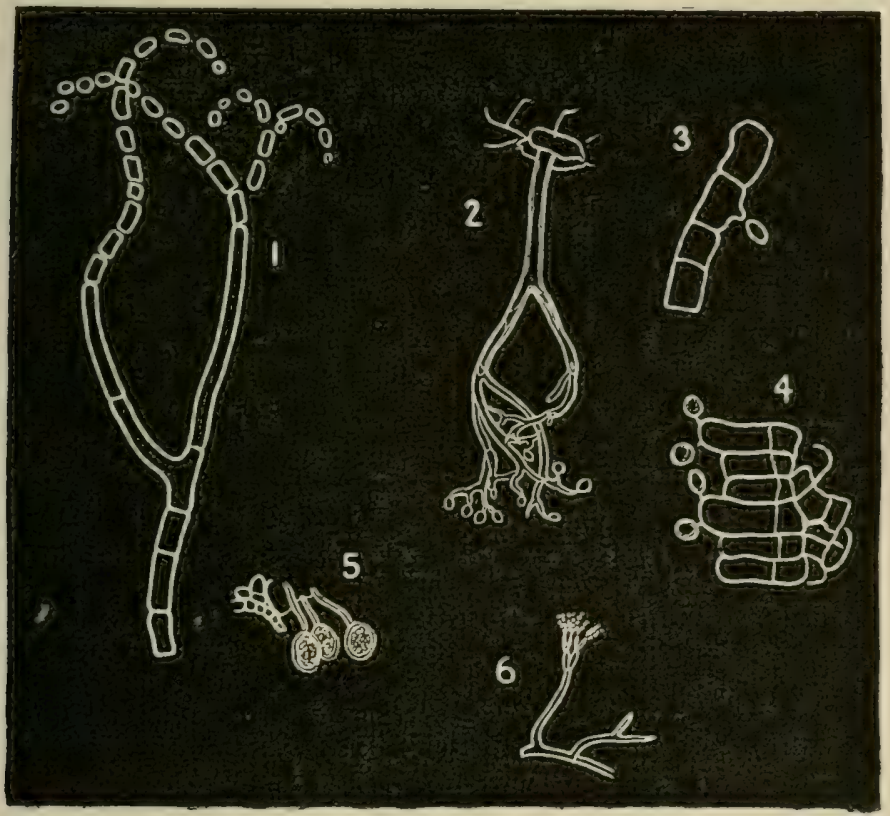

Fig. 26.-Conidia of Fungr. (1) Oidium lactis. (2) Peronospora candida. (3) Dematium pullulans. (4) Agaricus. (5) Uredospores of Puccinia. (6) Penicillium glaucum.

enzyme, by means of which the fungus thread etches or bores its way through the cell-wall. Thus regetable matter is first broken up by moulds, and then it is still further destroyed by bacteria. Part of it goes back to the air as carbonic acid, and part remains in the soil to be used as food by other plants. The mould itself decays rapidly as soon as it has exhausted its supply of food material. Most moulds live on decaying matters of one kind or another, such as horsedung, dead leaves, decaying fruits, jams, bread, meats, etc. ; 
but there are some which have become parasitic. A few species of Mucor and Aspergillus produce dangerous diseases in the lungs and bronchiae. A very interesting series of fungi has been discovered in Java and Japan. These are able to change rice starch into sugar, and also to change the sugar into alcohol. So that the fungus or series of fungi really carries on by itself the whole work of a distillery.

Mucor belongs to the class of Algal fungi which form spores by conjugation. The method closely resembles that of Spirogyra and other Algae. The other two fungi (Eurotium and Penicillium) are Ascomycete fungi, and form, besides conidia, a sort of sexual fertilisation which results in the production of a peculiar round mass of cells, called the cleistocarp, within which are the asci and spores. As these fungi are exhaustively treated in all books on botany, it is unnecessary to describe their spore formations in detail.

The Yeasts are another very important group of fungi belonging to the Ascomycete order, and living upon sugary material or on fruits of the most various kinds. They consist of single cells and multiply by a peculiar process of budding. A small projection appears at one end of the cell, enlarges, and eventually breaks off when it is mature. Sometimes these cells cling together in chains or colonies, which may consist of 30-40 cells. The cells vary in shape, but are generally round to ovoid, or sometimes oblong or cylindrical.

When yeast is placed in a sugar solution, it absorbs the sugar. The protoplasm then secretes a certain ferment, which breaks up the sugar and alcohol is produced, which is excreted through the wall into the liquid. ${ }^{1}$ This ferment, or enzyme, is probably a mucleo-

${ }^{1}$ There is some doubt as to this being the correct view, 
proteid (that is, it contains Carbon, Hydrogen, Oxygen, Nitrogen, Sulphur, and Phosphorus). It may be extracted from the yeast cells by crushing these in diatom earth, and by filtration and pressure. When extracted in this manner the ferment can by itself produce a vigorous alcohol fermentation in a sugar solution. The ferment is a very delicate and sensitive substance, and is almost as easily killed by poisons as the living yeast cells. Those races of yeasts now employed in breweries and distilleries have been cultivated from a very early period. Egyptian wine seems to have been manufactured on very much the same principles as those now used. The present yeasts in cultivation are very numerous, although all are merely races of probably one species, Saccharomyces cerevisiae. Each brewery or distillery, as a rule, possesses a mixture of yeasts which differs from that found anywhere else. Each brewery has also to guard against the insidious attempts of wild yeasts to enter and destroy the more useful cultured forms. Wild yeasts occur on the outsides of ripe fruits and appear to spend some part of the winter on the soil below fruit trees. They have also been found on bees and other insects which visit flowers and upon the green flies (Apliides) which secrete sugar. It is possible by Hansen's methods to isolate a particular race of yeast-plants, and even to form a colony capable of doing the whole work of a brewery from a single cell. This operation is necessary when brewery yeast becomes contaminated by wild forms. The process is difficult, but the principle is quite simple. A solution is made in which there is about one yeast cell in every drop of the liquid (generally brewer's wort). Forty sterilised flasks of the wort are then inoculated, each with one drop. There will be in most of these 
flasks a single cell, and a colony will form which can be easily seen in two days' time. If further accuracy is needed a mixture of wort and gelatine is made, and a very small quantity spread out on a covered glass, marked with squares: this is placed over a glass ring and the cells examined, and their position marked on a diagram. After leaving a short time (a day or so), the cover glass is again examined, and the cells are seen to have formed little colonies, which can be drawn off by the point of a needle and plunged in a flask of wort. They will then multiply in this until they can be removed to a larger one, and eventually will be numerous enough to supply a brewery. These races show considerable differences in their method of work, and in the energy of their budding, and of the fermentation they produce; and the most useful ones are chosen.

Under certain circumstances the yeast cells form spores of the shapes figured below. A drop or two of water and a small block of plaster of Paris are placed in the lower glass shell; then a drop of the yeast sediment is put on the block and the upper shell is placed over the under one. The air within is kept moist by the drop of water, and under the influence of the air the yeast cells will form spores. These vary in appearance and number, and the cultivated and wild races can generally be distinguished by the difference in the spores.

There are, as stated, different yeasts in almost every brewery, every vineyard, and every distillery, and the exact method of treatment also varies. Those found in hot countries and used for making millet beer, rice beer, etc., are also distinct. The bread yeasts are not thoroughly understood, but apparently differ from those 
usually employed in breweries in being exceedingly impure and containing a mixture of many different kinds.
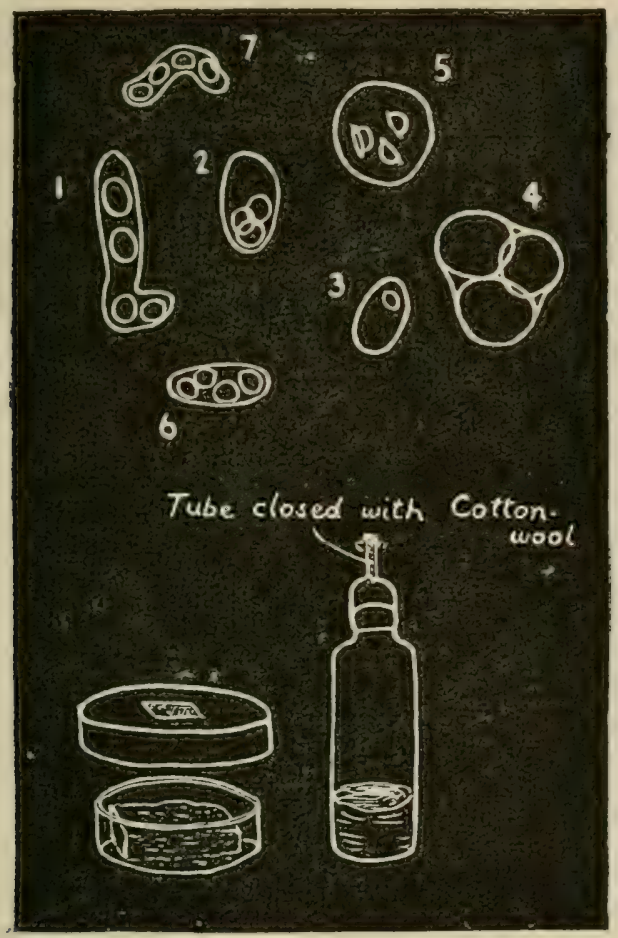

Fig. 27.-Yeast Spores and Alparatus for Cultivation. The spores figured are those of (I) Schizosaccharomyces sp. (a species from Jorgensen's laboratory found in Greek wine); (2 and 3) Saccharomyces ellipsoideus var. II. ; (4) S. cerevisiae var.; (5) S. anomalus. ; (6) S. Pastorianus var. I. ; (7) S. mahwra. Below are seen a Freudenreich flask for yeast cultures and a glass shell with plaster of paris block and its lid with a label.

Although the plants mentioned in this chapter are all exceedingly minute, it is clear that they are of very great practical importance. The work of Pasteur, of Lister, of Hansen, and of Koch, is all very recent; and yet it has revolutionised modern medical practice in many directions. All sorts of interesting possibilities can be imagined when a similar high level of achievement has been reached in other directions. We can see that the farmer will regularly sow his bacteria and 
increase his crop indefinitely; that tobacco, wine, or cheese of the most rare and precious character may be formed everywhere, and with certainty; that yeasts and moulds might be utilised to turn sugar, water, and a few cheap mineral salts into valuable food, as rich and far more easily digested than beef or mutton. None of these vistas seem at all impossible, if we remember the advance made by Pasteur and Lister on the achievements of their predecessors. 


\title{
CHAPTER XI.
}

\author{
FUNGI.
}

Mushrooms are not a favourite subject of study with most out-of-door botanists. There is some excuse for this feeling; for almost all British work is systematic, and it is almost impossible for most people to work up much enthusiasm over the mere naming of an Agrricus. Hard study is required to master the meaning of the author's description, as well as exceedingly minute and careful observation; whilst the end, the knowledge that it is only Agaricus laccatus (Amethy'stimus), does not seem to be worth the trouble. Yet the work done by Fungi is of infinite value, and is moreover full of interest to all lovers of nature.

A Fungus consists generally of two distinct parts. There is first the absorbing or feeding part of the fungus which obtains water and all other necessary nourishment from decaying organic matter, or from living animals or plants. This is generally a system of branched threads adapted to explore the material and with the power of secreting substances which dissolve cell walls or even woody matter. This absorbing part (mycelium), is often below the ground or immersed in a liquid medium. The second part of the fungus is intended for reproduction and is generally formed in air. Whatever the external appearance of the reproductive bodies, they consist essentially of a single or of 
many united fungus threads which are terminated by the spores.

The very simplest of all possible arrangements can be seen in such a form as Oidium lactis, where pieces of an ordinary fungus thread are split off and form the spores. Penicillium and Phytophora show a simple branching of the stalk. Even the spores of the mushroom family are not essentially different; for a mushroom is, though highly specialised, simply a united mass of fungus-tubes of which those that end in the basidia are spore-bearing. ${ }^{1}$

Somewhat more difficult to understand are the Cups of the Lichens and of the Ascomycetes; in these the entire fruit-body is probably the result of some process of sexual union. The spores are formed inside the fungus tube, and are not constricted off at the tip. Even in these, however, the body of the fungus is an agglomeration of fungus tubes and is not formed like that of the higher plants.

As they differ greatly in their appearance and mode of life, the main groups of Fungi are not difficult to distinguish from one another. The following rough classification may be of use to beginners:

I. The Mushroom Group. Toad-stools, Paddock-stools, Mushroom-like forms, and the large woody or fleshy Fungi found on trees and dead wood; Basidiomycetes (Hymenomycetes).

II. Puff-balls and the Birds-nest Fungi. Basidiomycetes. (Gastromycetes).

III. Small waxy or fleshy fungi found generally on dead sticks or decaying wood. The shape is almost always that of a cup, saucer, or plate: most are red,

${ }^{1}$ The conidial nature of the Basidiomycetes, here given, is not the usual view, but has the support of Dr. Massee. 
but some are pale yellow or lead-colour. The size of these cups is generally very small ( $\frac{1}{4}$ of an inch or less), but the dark red cups of some Pezizae are 2-3 inches in diameter. Ascomycetes (Discomycetes).

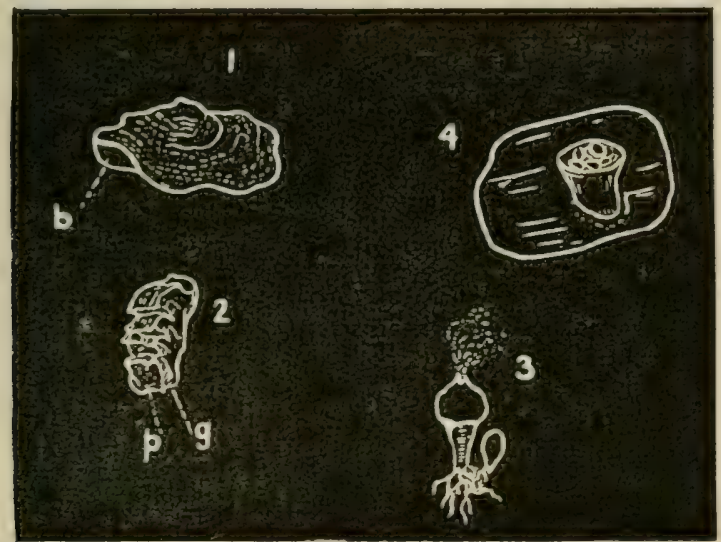

FIG. 28.-Forms of Fungr. (I) Polyporus betulinus. (2) P. connatus. (3) Puff-ball, Lycoperdon showing the escape of spores ; (4) Birds-nest (Crucibulum vulgare); $(\not p)$ pores on lower surface; $(g)$ spore-bearing part in section. Figures I-3 greatly reduced.

IV. Black dots found on sticks, herbaceous stalks, wood or bark (Sphaerias), and cinnabar-red spots, very common on dead wood and small twigs (Nectria). Ascomycetes (Pyrenomycetes).

$\mathrm{V}$. Orange, brown, or black lines, or round dots found on the living leaves or stems of herbaceous plants. Black dust in corn, etc. Rust and Smut Fungi. Aecidiomycetes.

VI. Grey or white mildews on living plants, generally on the underside of the leaves. Potato Disease Group. Oomycetes.

VII. The Slime Fungi occur either as jelly-like, formless bodies, or, in fruit, resemble very minute sacks full of spores. They are little round balls or more often with a supporting stalk, and resemble tiny champagne glasses or egg-cups. They will be found in very 
rotten wood generally in quantities. They are sometimes yellow or often white, brown, or red. They have no soft tissue, and the sack-wall is thin and papery. Myxomycetes.

VIII. Moulds, and IX. Bacteria will be found in another chapter (see p. I98).

It will be seen that two groups (V. and VI.) are found on living plants. These parasites produce diseases often of a very fatal character. Of the others, most live on decaying animal or vegetable matter (Saprophytes). Their chief function is to break up and get rid, as soon as possible, of all useless accumulations. A few in all the other groups are, however, also parasites, and do great damage in forests or amongst cultivated plants.

Of the Mushroom Group (Basidionycetes), the family Hymenomycetes are easily distinguished by their sporeformation. The little spores, which vary in colour, are hung singly on short stalks which project above the gills, or into the pits or cavities on the under surface of the mushroom. It is in woods that we find these fungi most conspicuous, and in greatest variety. There are two distinct crops, or harvests, of them in Scotland. The great fungus season lasts from the middle of September to some time in October. There is often a subsidiary season in the early spring, or at the end of winter. At these seasons the ground under the trees, or the "wood-floor," is dotted everywhere with mushroomlike puddock-stools of endless variety in shape and colour. Some are staring red; some blue-purple, or a sickly greenish yellow; others of a very inconspicuous brown or nondescript shade; often so closely resembling the dead lcaves amongst which they grow that they are very hard to see. As a rule the stalk and under 
surface is white. In the less conspicuous forms this assists in concealment, for the shadow thrown by the cap is neutralised. In the conspicuous species the white stalk and gills make them even more distinct and visible at a distance. Although the colours have been very closely studied as aids to the discrimination of species, nothing is known certainly of their use to the fungus. To those who know the habits of flies, it is obvious that the flat tops of the mushroom will readily catch the eye of an insect, and it will settle upon them as certainly as a hawk will alight on a pole set up in a field. In most cases the fly is probably attracted by. the colour. After it has alighted it will distinguish the smell, and crawl down to investigate the gills. It will thus get dusted with spores, and carry them away upon its feet. The writer has watched a slightly different procedure in the case of Agaricus rubescens, one of the common red species found in woods. A fly alighted on the upper surface ; after a time it seemed to be attracted by the staring white ring on the stalk of another fungus close at hand, and at once flew to the ring, and passed over the gills. The usual fate of these Agarics (unless suddenly killed off by the frost) is to be devoured by maggots. The mother insect will be greatly assisted by colour and smell in choosing a place for its eggs, and must carry the spores about if it goes from one fungus to another. The character of the smell also, which is often of a very offensive description, must be exceedingly delightful to all those carrion and other flies which live on decaying abominations.

The spores themselves are often coloured. As their colour is an important classifying character, any specimens gathered should be left overnight on white paper, with the gills facing downward, During the 
night the spores will fall upon the paper, and their salmon-pink, black, white, or yellow colour is a very useful help in determining the species. Sometimes the spores closely resemble pollen grains. In many species of Russula they are covered with minute spines, which would stick to the hairs on an insect's body. Similar spiny spores are found in many fungi not belonging to this group, as in Scleroderma, in most Rust-fungi, in Trichia, and others of the Myxomycetes.

There are, therefore, many grounds for supposing that the primary use of the colour and scent is to attract insects, and thus to aid in the distribution of the spores. This has been proved by observation in the case of Phallus impudicus, where flies, and especially "bluebottles," seem to revel in the disgusting slime which distinguishes that plant. Phallus belongs to the Gastromycetes. There is, however, much more to be learnt on the colour of Fungi. In "The Sensitive Plant," pt. 3, Shelley gives a peculiarly vivid and correct description of the impression left by the poisonous fungi :

"Betwixt the time of the wind and the snow,

All loathliest weeds began to grow,

Whose coarse leaves were splashed with many a speck,

Like the watersnake's belly and the toad's back. . . . .

Prickly and pulpous and blistering and blue,

Livid and starred with a lurid dew."

This applies not merely to poisonous fungi, but to poisonous plants in general, and is an excellent though impressionist description of their characteristics. Poisonous forms such as Bolctus Satanas, Agaricus muscarius, etc., are often, in fact, distinctly different from the majority. Now Fungi of this kind have no lack of enemies. Man, birds, roe-deer, squirrels, rabbits, not to speak of slugs, are fond of fungi, and 
devour them. ${ }^{1}$ It would be an advantage to the plant, therefore, to be protected from its enemies, and many of the harmless varieties have, no doubt with this object in view, assumed an appearance similar to the poisonous forms.

These resemblances of the poisonous and edible kinds make the eating of fungi rather dangerous; and the most extraordinary qualities have been ascribed to them, probably to check scientific investigation. Lightfoot has several excellent passages on fungi. "It is," he says, speaking of Agaricus muscarius, "of an acrid and deleterious quality. Hallier states that in Kamschatka it had driven people mad. The inhabitants prepare a liquor from an infusion of this fungus, which, taken in a small quantity, exhilarates the spirits, but, in a larger dose, brings on a trembling of the nerves, intoxication, delirium, and melancholy." Writing of a Boletus, he says, "Scarabs and Dermestes and many other insects feed upon and breed in them in abundance, and doubtless it is their proper food. It is a pity men or other animals should rob them of it."

Many of those fungi which are not poisonous but edible, and even pleasant to eat, are coloured in such a way that they closely resemble the dangerous species.

For example, Dr. Stevenson says, "Boletus edulis is reckoned one of the most delicious, but it very closely resembles B. Satanas, which is very poisonous." The table below shows two other close resemblances between the

\section{Poisonones.}

Russula Rubra Fr.

R. emetica Fr.

Agaricus lividus Bull.

\section{Edible.}

Russula alutacea Fr.

$\mathrm{R}$. virescens Fr.

Agaricus campestris.

1 The conspicuous species may be eaten by animals. It has recently been shown that the spores are not destroyed whilst passing through the animal's body. 
Now it is certainly the case that the whole genus Boletus is avoided by man because of the known poisonous character of B. Satanas and others; so that, in this case, the resemblance has been of use, and corresponds to quite similar cases of mimicry among butterflies (see Wallace).

The inconspicuous forms are probably visited only by some insect or slug which is intended to crawl over them. They also show details which are interesting and no doubt useful. For instance, the greyishred separate little scales on $\mathbf{A}$. rubescens seem useless; but if one searches for young specimens among the dead leaves and grasses, it will be found that, in the young state, the scales are close together, so that the hat is a nondescript greyish-red, which is the colour of the scales, and hence young specimens are difficult to see and escape notice, whilst the mature fungus is a conspicuous red, impossible to overlook.

Certain Agarics, including eleven species of Pleurotus, and other fungi, produce the so-called Phosphorescence. A luminous glow is given off by some substance secreted by the Fungus, and this light is supposed to attract insects which distribute the spores. There are twentyfive species of fungi known to possess this luminosity or phosphorescence.

In the shape of mushrooms there is also great variety. The main idea of a supporting stalk elevating the head, with the gills underneath so that rain may not injure the spores, is common to the whole group. But the exact curve of the cap, and the shape and thickness of the stalk show extraordinary variations. Some are in outline much like an umbrella; others are nearly spherical; and a great many have a small boss at the top, and then a concave line. This 
variety depends, no doubt, on the way in which the weight is supported. If dissected under a microscope, it is found that the stalk is made up of many minute fungus threads which pass up it, and then, turning outwards, run into and terminate in the gills. Hence the shape often resembles that of a sheaf of corn set vertically upright.

The part of the fungus which appears above the ground is simply the spore-carrying body. The threads, or mycelium, above-mentioned, pass from the base of the stalk into the ground and branch out in the soil of the wood. They are exceedingly thin and almost impossible to distinguish by the naked eye, but they are present in the soil of woods in enormous numbers. They probably occur only in the upper layers of the wood floor; but, wherever leaves are decaying, every square inch of the soil is thoroughly explored by these fungus-threads, or mycelimm. Hence it is easy to see that they are of great importance to the proper growth and development of the woods in which they occur.

Some fungi may be found upon decaying tree stumps. The threads or mycelium of these penetrate into the rotting material and decompose it. They begin by exploring the soft tissue under the cork, and between it and the wood. They then pass in along the medullary rays and break up the wood into a crumbling powdery mass. The threads are able to pierce the cell-ivalls. They can, in fact, excrete a special secretion which dissolves the cell-walls, and they can, therefore, enter every cell and absorb its organic matter. The woodpowder remaining is then attacked by the Slime fungi. The dry-rot fungus (Merulius lachrymans), recognised by the white, fluffy mycelium, or the brownish, irregular, 
flat fructification (not mushroom-like), originally broke up dead logs in forests; but it is generally found in houses, where it is much dreaded, as it often destroys the whole of the woodwork. In many cases the wood attacked by this fungus breaks into lines crossing at right angles. This is a useful sign of the existence of dry rot. A plentiful supply of air generally prevents its development, but, once in the woodwork, it can scarcely be exterminated.

Several of the ordinary mushroom-like fungi destroy living trees. They generally work in the same sort of manner ; and, having once obtained an entrance through the cork sheath, they grow everywhere up and down amongst the soft tissues, so that the tree eventually decays and dies. They spread from one tree to another, either by the spores, which are carried by wind or insects to some wound on the bark of a tree, or else by growing through the soil and attacking the roots. Agaricus melleus, for instance, often attacks trees in this manner. If the bark of a tree attacked by it is torn off, peculiar blackish-brown flattened fibres from $\frac{1}{16}$ to $\frac{1}{8}$ of an inch in diameter are usually found. These, rhizomorphs, are composed of mycelium threads agglutinated together. They grow out of the root of an infected plant into the soil; and then through the soil to the nearest roots, which they penetrate; and so they infect fresh and quite uninjured trees. Hence the importance of recognising and destroying these parasitic fungi is very great. It is also advisable not to plant woods of only one species of tree, as these fungi are often confined to one kind of tree, and in a mixed wood they are not so likely to be able to pass easily from tree to tree.

Others of these fungi are practically servants of the 
tree roots. They are attached to the outer cells of the young roots, and penetrate the surrounding soil. The tree takes from them nitrogenous and other matters obtained by the fungus from dead leaves, etc.; and they, in return, obtain a share of sugary material from the root cells. This fungus servant, or mycortiisa, is found on almost all trees and, indeed, on plants of every description, except willows, grasses, and some others found especially in watery places, where there is no lack of organic matter. There is, however, some doubt as to the exact nature of this fungus servant, or mycorhiza.

Agaricus is by far the largest genus. Lactarius is very similar to it in appearance, but has a whitish milky juice; and there are several other genera which are difficult to distinguish from Agaricus.

Polyporus is easily recognised from the fact of its under surface being dotted with numerous pores or holes, and also from its position, generally on the trunks of old trees. Sometimes the fungus is hoof-like, or bracket-shaped. $P$. versicolor is easily recognised by the bands of different colours on the upper side of the bracket. Other Polypori are irregular, corky, or almost woody masses found at the base of stumps, or on wood. One of them; Polyporus betulinus, makes an excellent razor strop. All of them might be utilised as charcoal for gunpowder manufacture, but the difficulties involved in collection on a large scale are probably too great. Most of the Polypori attack decaying wood or are parasitic on trees, but a few may be found on the ground.

The Basidiomycetes contain besides the Hymenomycetes (Mushrooms, Polyporus, Boletus, etc.) another group, Gastromycetes. This group differs from the 
hymenomycetes in the spores being formed inside the body of the fungus, which is generally spherical or pearshaped, and is, in some cases, entirely subterranean. The best known of these fungi are the Puff-balls. Scleroderma, one of these gastromycetes, is from I to 3 inches in diameter and when fully ripe, consists of a mass of minute blackish or purple spores contained in a sort of membranous sack. When trodden upon, the sack bursts and the spores are scattered by the explosion like a cloud of dust. They are then either carried off by the wind, or stick to the fur of the animal which trod upon the plant. Lycoperdon is very similar though smaller; but it differs in the pear-shaped or globular sack containing, besides the spores, a peculiar entanglement of fine fungus threads, the "capillitium," which prevents the spores from being carried off at once. They come out in small quantities whenever the ripe fungus is touched. Both these forms are found in woods, either on the ground or near tree stumps; and occasionally, also, they are met with in meadows or pasture. The little Birds nest Fungus (Cyathus or Crucibulum) occurs on the bark of trees or on the soil; it is very like a minute brown tumbler, $\frac{1}{4}$ to $\frac{2}{3}$ inch across, and contains numerous little round bodies, each attached by an elastic cord to the bottom of the tumbler. These bodies contain the spore-bearing cavities and the elastic string is used in their distribution. Another genus, Nidularia, only differs in the little egg-like bodies being free and not attached to the cup.

Another very large group of fungi, the Ascomycetes, is to be found on decaying sticks, old wood, often below the bark, or upon animal dung. They are distinguished botanically by the spores being found inside long oval tubes called asci. The group is a very 
large one and contains many common moulds (Chap. X. p. 2 I O), yeast (Chap.X.p. 2 I 2 ), and most of the lichen-fungi (Chap. XII.). The mycelium of most of these penetrates rotten wood or decaying matter and the fruit is more or less cup-shaped, and quite like that of the lichens with very often the same red or yellow colours. The bright red Pesisa coccinea with cups I to 3 inches in diameter is exceedingly beautiful, especially when the old logs on which it grows are covered by bright green mosses. Most of the Ascomycetes are however very small, often only an $\frac{1}{8}$ of an inch in diameter, and must be carefully searched for. The cups are often supported on little stalks; and sometimes, as in the Morels (Morchella), the asci and barren cells cover an irregular wrinkled surface spread like a cap over the top of a stout support. In one group, the mycelium develops inside the bodies of grubs or caterpillars, and the supporting stalk ends in an orange club-shaped mass which contains many little cavities, each containing asci and barren cells (Tombibia militaris).

In the sub-division Pyrenomycetes, the mycelium is similar, but the ascus part is compound and there are many little pits in which the asci are enclosed. Of these Nectria cinnabarina is exceedingly common. This is the fungus which forms hundreds of brilliant red spots which break through the bark of dead twigs. Another species, fortunately not so common, $N$. ditissima, produces the "canker" of Beech, Apple, Ash, and other trees. The spores fall on a wounded part of the trunk and the fungus threads produced from them at once attack the living tissues on each side. This part of the tree ceases to develop and the neighbouring cork-forming and bark cells at once begin to develop cork and multiply rapidly; the result is a ragged black 
and deformed cavity in the trunk with raised edges. It has been stated that this canker fungus of trees is identical with the cancer which attacks mankind. M. Bra claims to have produced cancer in rabbits from the spores of this fungus, and also to have produced canker in trees by infecting with human cancer.

Amongst other important fungi in the Pyrenomycete group are Ergot (Claviceps), which grows in the ovary of the rye; and if eaten when ground up with the grains, produces paralysis, decay of the toes or fingers and other horrible effects. The Tuberaceae, or Truffles, are subterranean fungi found in rich humus under trees. The fruit is a more or less rounded body containing many cavities in which are the asci and spores.

The Rust and Smut Fungi (Aecidiomycete and Ustilagineae) are moreeasily found and named than the preceding groups. They produce some of the most dangerous plant diseases, and seem to have a special partiality for settlers' crops in newly opened countries. They are generally easy to see, as the orange or brown stripes or spots attract attention. The plant attacked is also different from other plants of the same kind, it is more sickly-looking and often yellower than its neighbours. If one passes slowly through a field of thistles, unhealthy specimens, with leaves more upright than usual, and covered with brownish-red spores on the under surface, are easily distinguished. The fungus attacking them is Puccinia suaveolens whose spores have a distinct odour, rather like that of the Evening Primrose. Coltsfoot leaves also are often covered with conspicuous red spots on the under surface, especially where the plant grows in great numbers. But almost every plant has its own special rust-fungus, and many a smut- 
fungus in addition; so that it is not difficult to get specimens.

Sugar, as well as perfume, is occasionally secreted with the spores. These, like the colour, are undoubtedly intended to attract insects. No less than I 35 species of flies have been seen visiting one of the Euphorbia Rusts. The spores have also been found in the footprints, left by flies on window panes after they had visited the fungus. The spores are also to be found in the air and have been detected in dust samples taken from greenhouse shutters.

There are several interesting points connected with the mode of life of these rusts of plants. The species are very peculiar, considered as species. Forms which appear absolutely identical are to be found living on allied plants; but the spores of the Rust (Puccinia graminis), living on wheat will not infect barley or couch grass, and those of the same fungus on barley will not infect wheat. Even more remarkable is the manner in which they migrate with the season. The classical example, Puccinia graminis, lives on the corn during summer and spreads from corn to corn by orange spores. In autumn the fungus produces hard black double spores which rest all winter on the ground. As soon as the Barberry leaves are out, tiny windblown spores are formed from these black spores which are carried to, and infect the barberry leaves. They produce very peculiar cup-like spots, orange-red in colour, on the under surface of the leaf. The Aecidiospores formed in these cups carry the disease from Barberry to Barberry and then back to the corn. Their life is thus like that of those hotel attendants, who migrate from the Riviera to Switzerland, and so obtain support from different sets of tourists. Coleosporizm senecionis 
divides the year between the Groundsel or Ragweed and the leaf needles of Pines. Gymnosporangium juniperimum lives on the Rowan from July to October, and on the Juniper from May to June. The Gooseberry disease, Accidium ribis, seems to pass part of its time on the leaves of sedges.

As the whole series of Rust fungi live inside the plant or "host" affected, and only form spores when ripe, they are exceedingly pernicious agricultural pests. A plant once attacked is doomed to destruction. The coffee-leaf disease, Hemileia rastatrix, is said to have destroyed plantations worth some $£_{\mathrm{I}} 6,000,000$ in Ceylon; and the damage done annually by disease to the crops in the United States is estimated at from 25,000,000 to $30,000,000$ dollars for cereal crops, and at about I 50 millions to 200 millions of dollars for all sorts of crops. ${ }^{1}$

The reader is recommended to study Plowright's Uredineae and Ustilagineae, a very perfect handbook for this group of fungi. The Smuts or Ustilagineac are allied to the Rusts or Uredineae, but the spores are generally black, and form the Blackball or Smut often seen in oatfields. Ustilago is the commonest form, and species of it are found specially intended to attack Oats, Wheat, Barley and Rye respectively. Tilletic Tritici is the Bunt or Stinking Smut of Wheat. Its spores have a distinct and disagreeable odour of stale herrings. It has been found that these pests are greatly diminished by soaking the seeds for five minutes in hot water or in solutions of copper sulphate (details will be found in Percival's Agricultural Botany).

The Mildews or Peronosporeae belong to another group of fungi, the Phycomycetes. This is divided into two

${ }^{1}$ Probably all kinds of diseases are included in the last estimate. 
groups: the Mucors, which are very common moulds (see Chap. X.) and the Oomycetes, which includes a very great number of destructive parasites. Amongst the most interesting are the Salmon-disease Fungus, the Vine mildew which gives a "dead-leaf" taste to claret and has been exceedingly destructive in the Medoc country, the Damping-off Disease of Seedlings (Pythium de Bary'anum), Mildews of many cultivated plants, of the common Nettle and of Brooklime (Veronica Beccabunga).

The Potato-disease (Phytophthora infestans) is perhaps the most important of all, and its history is fairly well understood. Like most of the mildews, the fungus produces whitish spots on the under side of the leaves. On examining these with a strong lens a whitish bloom or fluff may be noticed, which is the spore-bearing part of the fungus. This consists of little branching fungus threads upon which the oval spores are seated (see p. 2 I I). These threads emerge from a stoma of the leaf and run back in every direction through the tissues of the leaves and stalks, absorbing food material from every cell that they touch. The tissue of the leaf becomes broken up and disorganised and the leaf begins to rot and decay. The fungus is spread from leaf to leaf by the spores which are blown by the wind, or carried by animals, from one leaf to another. They generally fall upon the upper surface of a leaf, and if the weather is wet so that the atmosphere is moist, the spores germinate. Each generally breaks up into seren or more small rounded bodies (zoo-spores) each with two thin, hair-like tails. They are able to swim through the water on the leaf, as the tails contract or lash about, so that the zoo-spores can travel over the surface. After a time they come to rest and the tails are lost: the zoo-spore 
then bores its way down into the leaf and forms a fungus tube or thread, which extracts food from the leaf cells, and grows all through the tissues. Towards the end of the potato season they grow down the shaw and attack the young tubers. If these are planted, the young plants are diseased from the beginning and are soon killed by the fungus, but they may, of course, infect a whole field of potatoes before they die off. Nothing in the nature of a cure is known; but, of course, the selection of thoroughly sound tubers is of great assistance. If the weather is very wet, the disease is always severe, as the germination and movement of the zoo-spores is greatly assisted by the water on the leaves. The leaves are sometimes sprayed with Bordeaux mixture; and, if this is done in time, the progress of the blight may be greatly limited.

The Slime fungi (Myxomycetes or Mycetozoa) are often considered to be animals and not plants, but they are generally placed amongst the fungi. Most of them are to be found in dead or rotten wood, and they seem specially adapted to destroy persistent tree stumps. They are very difficult to distinguish unless when in fruit; but any rotting $\log$ of wood is pretty certain to yield specimens from September to February, either under the bark or upon the exposed surface. The fructifications are very small, but, when seen with a lens, exceedingly neat and graceful. They vary greatly in shape. Some are like pin heads; others are the shape of a champagne or wine-glass; in many species the heads run together forming whitish and curved convolutions; others are globular and may even be a quarter of an inch or more in diameter. Lycogala miniatum, for instance, is a dull olive brown, or pinkish grey to reddish brown, and is extremely like a small Puff-ball. 
It is very difficult to see, as it is nearly the same colour as the bark on which it is seated. It consists simply of a thin skin containing a quantity of spores entangled in a thread-work (capillitium). When touched gently the skin bursts and the spores fly out in a dust-cloud. Thus

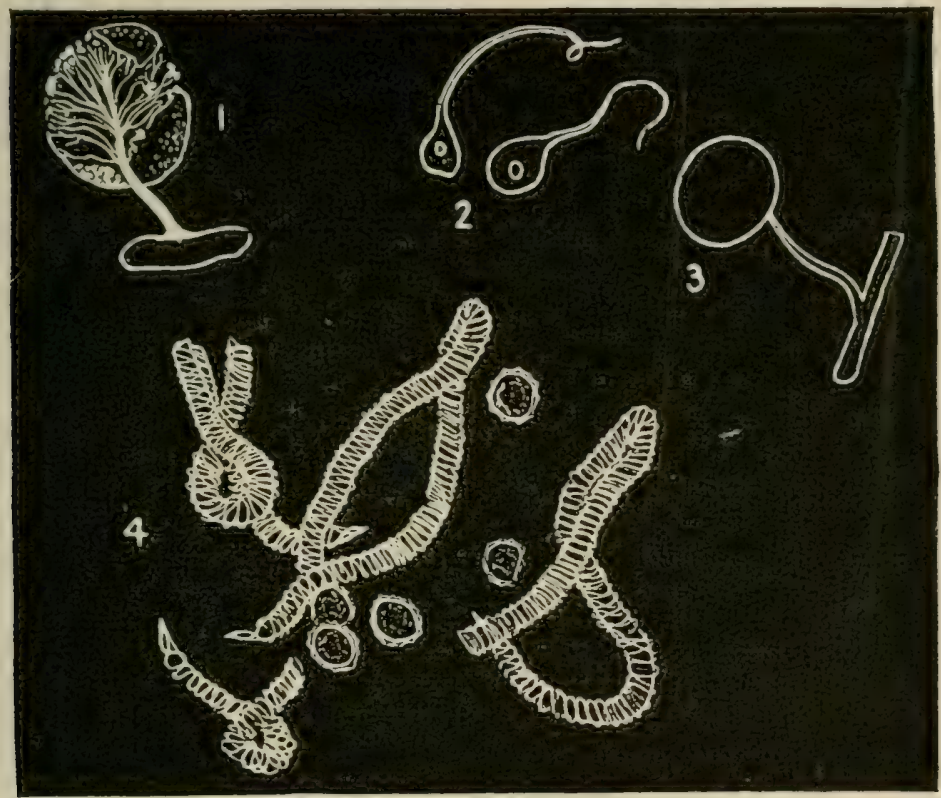

Fig. 29.-Slime Fungi. (I) Comatricha. (2) Zoospores in active condition. (3) Craterium. (4) Trichia spores and capillitium.

this species resembles the Puff-balls in the distribution of its spores. In other cases the spore-cases or spores are decidedly coloured, and often very conspicuous indeed ; all shades of red and orange are common ; some are purplish-blue, violet, bright yellow or pure white. Not infrequently there are iridescent tints. This shows that probably minute insects and other creatures, which are generally very abundant in old wood, are intended to carry the spores. The Capillitium, in which the spores are contained, is intended to preserve them in its interstices so as only to allow them to escape gradually. 
Under the microscope it is often like the finest lacework but the beautiful curves and orderly entanglement of the threads are quite beyond description. These threads are often ornamented with spiral lines or spines which probably alter the expansion and contraction when the amount of moisture changes.

The spores are very often minutely spiny or warted, and, in wet weather, will germinate in from 4 to 28 hours. Each spore becomes a small pear-shaped piece of protoplasm, with a single whip or tail much longer than itself. The whip lashes, and coils itself round in a very vigorous manner, and the spore is dragged about in all directions, often turning somersaults. Thus, in a wet film, on the wood surface, the spores are able to explore every crack and crevice, until they find a spot with suitable nourishment. They then fuse with one another, and lose their whips or tails, becoming a slimy mass of protoplasmic material, which is called the Plasmodium. This seems to live and move like an Amoeba. It can enclose bacteria or pieces of decaying organic matter, and digest them. It can also move, and it shows distinct preferences and objections as regards water and chemical solutions. In colour these plasmodia differ; they are white or rose-red, or sometimes yellow; they are often very like the excrement of birds. After a time they come to rest, and begin to form the sack, spores, and capillitium. The spores are formed round the nuclei of the plasmodium, and the protoplasmic matter secretes the outside envelope and the capillitium (see Lister, "Mycetozoa").

Some of these plasmodia are found on decaying mosses or on dying grass leaves; one species is very abundant in old tanyards. A peculiar parasitic species, Plasmodiophora Brassicae, is the cause of the "Finger and 
Toe" of Turnips and other Cruciferous plants. It is found in the roots, which become distorted and greatly swollen by the absorption due to the fungus. If the root is examined in July, the cells will be found filled with the yellowish slimy protoplasm of the parasite. Later on, in October, this has changed into multitudes of little black spores very like grains of gunpowder. When the turnip crop is lifted, the lower part of the roots and very often the diseased plants are left lying in the fields, or perhaps thrown against the side of the hedge. These gradually decay, and the spores are distributed by the wind or left lying in the soil. Next year they germinate, and are able to search the soil for Charlock or other Cruciferous weeds, on which they pass their time until another turnip crop is grown, when they will of course be quite ready to attack it. The disease is naturally most prevalent in places where the soil is damp. The application of lime is said to check the spread of this fungus, but probably the destruction of Charlock and other Cruciferous plants, and especially the careful removal of all diseased turnips, would be much more efficacious.

It is obvious that the main importance of the Fungi lies in their function of breaking up organic matter. Even those which are parasitic are of use, as the standard of efficiency for the species is maintained by the destruction of the weaker individuals. There is no very distinct border line between saprophytes and parasites, or indeed between the former and such species as are in intimate association with the higher plants, like the mycorhiza of trees.

They are in all cases obviously a necessary group of plants, and the study of them, though difficult, is interesting, and is also of great value to agriculture, 


\section{CHAPTER XII.}

\section{LICHENS AND THE ROCK FLORA.}

Crottles or lichens are a very exceptional group. They consist of two distinct and different plants, an Alga and a Fungus; which, by combining forces, are able to persist and to flourish in places where neither could exist separately. The Algae are unable to do without a plentiful supply of water. Most of them are permanently submerged, while the rest occur either in places which are kept almost perpetually moist by trickles of water, or amongst damp moss. The Fungi are, as a class, perhaps more delicate than any other; a single night's frost will utterly destroy all the Agarics which are in fruit, and very dry conditions seem almost as fatal as frost. Yet the lichens, formed of an alga and a fungus, are able to endure the worst weather, and to stand exposure to every sort of climate without the least injury. A lichen-covered boulder on a Highland mountain will suffer in one year the most extraordinary vicissitudes. During the winter severe frost continues for weeks together. Sometimes rain falls almost every hour for a month or more, and during that time the lichens are submerged. In summer there may be three or four weeks of dry weather in which scarcely any moisture, except that from dew, reaches the lichens, and on sunny days the boulders often get so heated by 
the sun's rays that the stone becomes almost too hot to touch.

And yet it is upon such boulders that lichens are found in profusion. The fungus forms a sort of nest or home in which the algal cells are enclosed. It also absorbs water and such nitrogenous and mineral matters as are necessary, whilst the alga obtains the sunlight-energy and carbon which are essential to the life of both. There has been much controversy as to the exact degree in which the two co-operate. Such words as commensalism, consortism, symbiosis, helotism, have been invented and defined, and have also been shown to be unsuitable and inexact by many writers. It is, however, quite clear that the life of an ordinary lichen is not possible unless both members are present, and that the fungus and the alga are absolutely dependent on one another. It is not difficult to grow the fungus by itself in an artificial nourishing solution, and with a little trouble the algal cells can be separated from the lichen and will develop freely, if they are given all they require. But neither could exist alone in the places where the lichen thrives, and thus, as regards lichens, the controversy is quite unnecessary.

The structure of the lichen is simple, and yet is exceedingly well suited to its position. The fungus part consists of a series of fungal threads or hyphae. The large leaden-brown lichen Peltigera canina, common in woods on moss, is a fair example of the general structure. The underside of this lichen is white, and covered with an irregular projecting network of yellowish-white veins, bearing at intervals distinct brown or whitish hairs, or rhizines. These rhizines attach themselves very firmly to the mosses, dead 
leaves, etc., on the ground. They are made up of fungus-filaments woven or united together, and represent the absorbing system. These absorbing rhizines vary greatly in structure and functions. In some of the other lichens, owing to the peculiar conditions of their life, pieces may be torn away by wind. If these pieces come in contact with a stone or, perhaps, the bark of a tree, special grappling rhizines are formed, which fix themselves to the support. They grow out from the lichen at right angles to its stem, and are very rapidly formed. They even increase in length and thickness after they are attached. They are well adapted to hold on to a support, as the fungus threads of which they are composed run lengthwise, and are thick-walled. If accidentally broken off, new grappling rhizines may be produced.

Sometimes different species of Cladonia, or even different lobes of the same plant, may grow together and anastomose. The younger lobes are also often parasitic upon the older ones, as may be seen in Parmelia saxatilis. On examining a cross section of Peltigera canina with the microscope, it is easy to see that the upper surface of the lichen is made up of fungus threads firmly joined together. Probably the cell walls of those threads stick together by a change of their outer surface into some gelatinous or gummy modification (mucose variety) of the cellulose. The lower surface is not so distinct ; it is, indeed, interrupted, and not continuous. The central part of the lichen consists of loose entangled fungus threads, and the algal cells are arranged in an irregular layer amongst these threads and near the upper surface, where, of course, they will be near the light. It has recently been shown by Dr. Salter that all the living parts 
of the lichen are united by innumerable connections, which involve an anatomical union. The colour of the upper surface is generally leaden-ash colour to brown, and is fairly conspicuous. Towards the edge of the lichen the lobes spread outwards and often turn slightly upwards. It is at the edge on these lobes that the lichen-cups are found. They are of a conspicuous

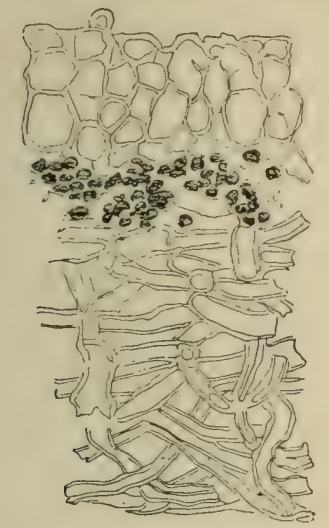

$?$

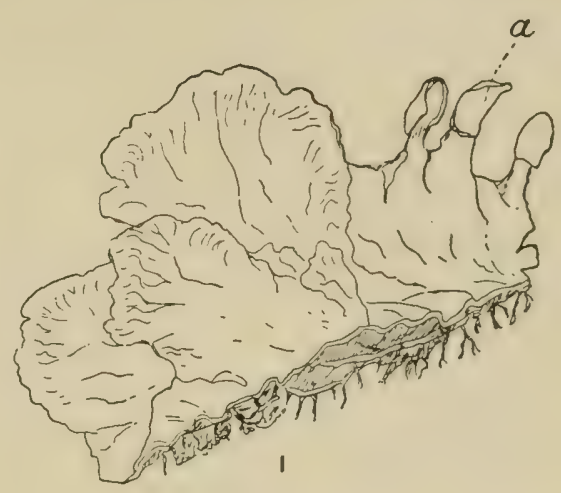

Fig. 30.-A Lichen (Peltigera canina). (I) View from above with undersurface bent upwards to show the rhizines and nerves: three of the shieldshaped cups are shown at $a_{\text {. }}$ (2) Section of lobe greatly enlarged, showing the loose fungus tubes of the central portion which are fused together to form the upper surface; between them are many small algal cells arranged in a layer near the top.

reddish colour, and are about a quarter of an inch in diameter, generally extending almost round the small lobe which carries them. Insects are sure to notice them, and after alighting upon them will probably carry off spores when they leave.

The "cup," or apothecimm, of Peltigera is rather different from the type usual in the lichens. In most forms it is like a shallow plate or saucer with or without a rim; sometimes it is swollen and globular. It is, however, almost always very small, from $\frac{7}{16}$ to $\frac{1}{4}$ of an inch in diameter. The bottom of the cup is covered 
by closely-packed upright cells of two kinds. Some are very narrow, though a little swollen at the tip (pcraphyses); the others (asci) less numerous, are oval, and each contains eight brown-walled spores (ascospores). The surface of the cup is generally covered by a dusty material in which algal cells also occur, so that the insects carry off, not only the fungus spores, but also algal cells. This lichen cup is probably the result of a process of sexual fertilisation. It may be taken as corresponding to the "cystocarp" of the Red Algae or Florideae. In these a chain of cells, of which one is the egg cell, terminates in a long hair-like cell called the trichogyne. The male cells are produced in clusters situated like the trichogynes on the ends of the branches. These male cells are carried to the trichogyne. One of these male cells then enters the trichogyne, and passes down inside it until it reaches and fuses with the egg cell. After this sexual union, a great development takes place, not only in the egg cell, but in those cells which surround it. Eventually by the growth and division of the egg cell and its neighbours the cystocarp is formed. In the lichens the process seems to be very similar, and trichogynes are also formed, but the result is the lichen cup. Only the asci are formed from the egg cell itself, the others (paraplyyses, and those forming the border of the cup) are produced by the neighbouring cells. ${ }^{1}$

Lichens also reproduce by a sort of budding. Small pieces of the substance break off, and are carried away by the wind. These are called soredia, and generally look like greyish-green dust. The lichens have also non-sexual spores, which are produced in small pits or

${ }^{1}$ Further details may be found in Dr. Darbishire's account. It is curious to find the fungus of the lichen showing a great similarity in its reproduction to the Red Algae. The Alga of the lichen belongs to a totally different group. 
cavities on the surface of the frond. These spores will germinate and form a new lichen if they are carried to a favourable position.

Lichens are very difficult to name, because, unfortunately, the number of species has been absurdly multiplied. Very many are only known by one solitary specimen, and are described in perhaps eight lines of diagnosis. Thus for beginners it is very difficult to make a start, and it is therefore necessary to give a more detailed account than in the cases of other groups.

We will divide the lichens into the following roughly characterised groups.

Erect-branched lichens, with stems more or less flattened, such as Evernia and Ramalina. These are found on the bark of old trees or on rocks by the seaside. They are small branching shrub-like lichens, generally of a greyish or yellowish-green, and are distinguished by their flattened or irregular rounded stems. The flattening will enable them to intercept more light than Usnea and Alectoria (see below); whilst they are still sufficiently flexible to turn about, and so to resist being torn off by the wind. Most of these are found on trees, and especially upon the trunk. Evernia prunastri, which is very common, is white underneath, whilst in Evernia furfuracea the lower surface is black or dark-coloured. Ramalina has both upper and under side of the same yellowish grey-green colour. The seaside Ramalinas grow on exposed rocks, and have rather large swollen yellow cups. The others, $R$. farinacea and $R$. fraxinea, grow on trees often in fairly dense woods. The first is whitish, and has narrower much-branched pointed lobes. The second has a broad, green frond, and is only slightly branched. 
These wood-lichens, Evernia and Ramalina, as well as Usnea, Alectoria, and Parmelia physodes, are by no means without real importance to the forest (see p. 308).

The Old Man's Beard Lichens belong to the genera Usuea and Alectoria. They are generally confined to old long-established woods. The Usneas are short, upright, grey-green tufts. Their stems and branches are round and not flattened or irregular, as in the Evernia group. The Alectorias are drooping or hanging and much longer ( 6 inches to I foot), of a darker browngreen, and thinner and more slender. They are thus able to yield to the wind and their smooth, almost shining surface will prevent any friction with the air. The cups are very seldom formed in Usnea and Alectoria but the soredia are easily carried off by the wind. Both of them seem to prefer unhealthy trees, probably because the cork is not being properly thrown off by a vigorous increase in thickness.

The cup and trumpet lichens or Cladonias are exceedingly pretty little plants generally under two inches in height. They vary in colour between pure white and grey green, but a few of them are almost brown. They consist of two distinct parts. The cup, trumpet, or small, erect, simple or branched stalks (podetia), upon which are the head of spores or masses of grey soredia, and the flat, grey-green lobes, which grow over the soil and carry on the work of carbon assimilation and of absorption. Their classification depends upon the colours of the cups and upon the character of the little lobes or scales of the ground portion. In the Reindeer-moss lichen (Cladonia rangiferina) there is no ground part, the stalks having developed into erect branching tufts like small shrubs generally 3 or 4 inches high. All these branches are slightly bent over at the tip and occasion- 
ally brown cups or heads may be found on them. Generally, however, this lichen does not bear any cups. It is to be found on bare wind-swept rocks, or in barren places thinly covered by moss and heather. In the Norwegian Highlands, Cladonia rangiferina colours the landscape a yellow grey, and in the desolate wastes of

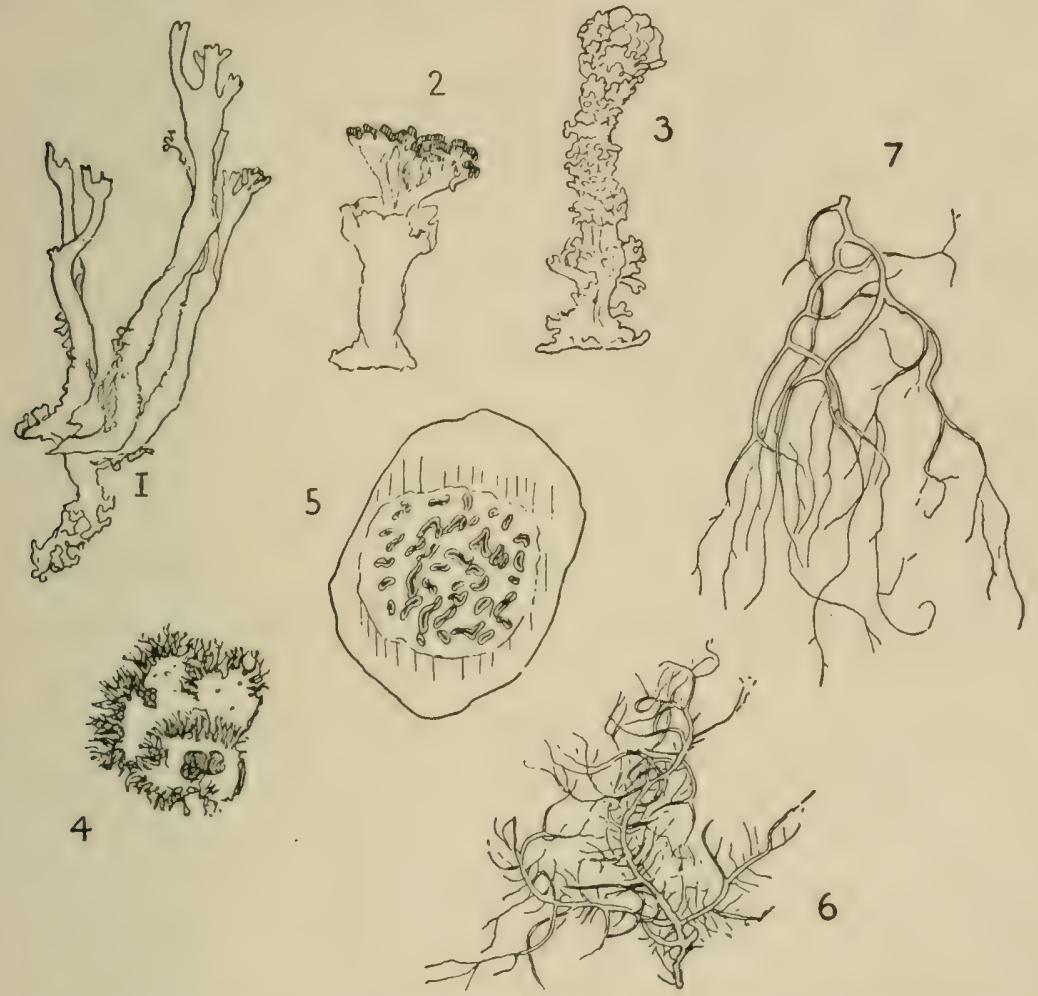

Fig. 3r.-Liciens. (1) Cladonia cenotea. (2) C. cariosa. (3) C. squamosa. (4) Gyrophora cylindrica (part only of the rosette is shown). (5) Opegrapha amphotera. (6) Usnea dasypoga. (7) Alectoria jubata.

northern Siberia and Russia it forms regular "lichen heaths" (Alechtenheiden), and really is the main pasture of the reindeer.

The other Cladonias are divided according to the colour of their cups. These are either a brilliant scarlet or a rich dark chocolate-brown. The height of the 
little stalk is just sufficient to bring it a little above the level of the mosses and other plants. As flies and other insects habitually hover about, covering the ground like pointers at work, some five or six inches above the soil or just clear of the vegetation, these bright red or brown cups must be conspicuous, and they will alight upon them and so dust their feet with spores. Dead mosses are a favourite situation for the Cladonias; as a rule the mosses must be dry for if they are kept moist other mosses continually develop and the lichen is kept off. Amongst other situations favoured by Cladonias are the following: old walls or dykes in dry, windy places (on the old dead moss between the stones); dry woods; old pine needles; wall tops; and, when old woods have been slightly thinned and many old stumps have been left, Cladonias will be found round the base of almost every tree. On the moors they are very common on dry peat, and about the roots of old and struggling heather; and on highland rocks, they are abundant everywhere.

There are many species of Cladonia. Some idea of the manner in which they have been sub-divided may be gathered from the fact that, of one British species alone, there are no less than five varieties, four forms, and two sub-species. The absurdity of this sub-division is clear, if one bears in mind the fact that there are not, in all probability, more than six botanists in Great Britain and Ireland, who are capable of naming any species correctly.

The stalks or stems of Cladonias are always hollow, so that they have the "cylinder structure," and hence are able to stand erect in spite of the winter storms. C. cervicornis and others have a well-developed ground portion of leaf-like lobes which resembles the Parmelia and Physcia group. 
These Parmelias and Physcias spread out in little flat rosettes, and generally grow in a zonal or circular manner. They consist of many rounded lobes, which are, as a rule, whitish or brown on the under surface. The prostrate habit is necessary as a protection against wind. Their growth is very slow, about half an inch in the year, though not so slow as is generally believed. Even at the rate of half an inch in the year a patch eight inches in diameter will be sixteen years old. Parmelia plyysodes, which is the regular greyish-white lichen common on the bark of both small and large tree branches, is the commonest of all lichens; and Parmelia saxatilis, which often covers old walls and dykes with hundreds of thousands of flat grey patches, is almost as common. The lobes divide in a forked (dichotomous) way and have a brown colour on the underside near the tip. Physcia parietina is very abundant on rocks, walls, or palings near the sea. It is a conspicuous reddish-yellow, and can be distinguished by an insect from a long distance. On reaching the patch the insect visitor is at once attracted by the bright orange, saucer-like cups (about $\frac{1}{8}$ to $\frac{1}{4}$ inch across) which stud the surface, and crawls over them and covers itself with spores. Other Parmelias and Physcias resemble P. physodes and P. saxatilis in being grey, whilst others again, are exceedingly small blackish or brownish patches on the bark of trees. Many of them are very closely pressed to the ground or to the bark, and are often difficult to distinguish from the Lecanoras. Peltigera, and Gyrophora belong to the same tribe as Parmelias and Physcias. The former has been already sufficiently described. Gyrophora is generally found on mountain rock or boulders in alpine districts, or upon seaside rocks and stones. It is a mournful-looking plant, sometimes 
resembling rosettes of black paper, or leaden-grey discs with black fringes at the edge. It is one of the hardiest genera, and lives in the most exposed situations and in a very variable climate.

The Crustaceous Lichens produce crusts or scaly matter or stains on rocks, stones, wood, or bark. They are exceedingly difficult to study especially as they adhere by the whole under surface so that it is necessary to break off pieces of the stone or wood to obtain specimens. Lecidea alone consists (according to Leighton), of 393 British species, of which no less than 230 grow on rock or stone. Even this is a large number, though it is insufficient for other botanists who have raised the number of species to six or seven hundred. An old rock or stone wall seems at first to be of a monotonous indeterminate colour, probably some sort of dull grey, in no way attractive; yet, if such a surface is closely examined, the variety of exceedingly delicate colour-contrasts in these crust and stain lichens is seen to be very great. These Lecanoras and Lecideas vary both in the colour of the crust, and in that of the tiny cups, which are always different in tint, though in harmony with the ground colour of the lichen. Shades and contrasts are to be found amongst them, which appear nowhere else in Nature, and are certainly never copied by artists. The colour of the body or crust is found to vary, being bright yellow, pale ochre, citron yellow, chestnut colour, mouse colour, different shades of grey and green, cream colour, lead colour, blue-black or pure black, tawny, brown, rusty red or pure white. The cups in Lecidea are generally black and without a distinct rim. They are distinguished by this last character from those of Lecanora which have a very marked border, and a rim distinct from the 
general crust. Lecanora is generally grey or whitish though sometimes it is yellow, tawny, orange red or even vermilion. The cups of Lecanora are in most cases reddish brown but they vary also. Sometimes the cups are a ghostly pale colour clearly brought out against the grey green background of the frond; or they may show rich deep crimson on pure white. The. tiny bright yellow cups of Lecanora vitellina especially, have quite a startling effect when one suddenly notices them on monotonous grey rocks or concrete walls. The colour is no doubt of the same importance as it is in the larger Parmelias. It is easy to observe very minute insects wandering about or flying over these lichens but it is difficult not to disturb them; still harder to catch them; and to get them named when caught is quite impossible. These Lecanoras and Lecideas are of great importance in the flora of rocks and stones. Another crust-lichen, Pertusaria, forms an uninteresting leaden-grey crust very common on tree bark. It has generally no cups, but is recognised by the small pure white discs, really soredia, scattered over the frond. Another group, Graphidei, can be recognised by their forming greyish or white stains on bark. They have no cups but have instead, black or brownish lines very like short scratches with a pen. Graphis and Opegrapha are the two common forms. Very old trees are sometimes attacked by another group, Calicieae. The lichen looks like a yellow or grey dust covering deep furrows in the bark. On very close observation minute black stalks ending in pin's heads may be seen. These are the fructification of the lichen.

This extraordinary situation is interesting as an example of the struggle for existence which has resulted 
in the occupation by a specially adapted plant of a most unusual and exceptional habitat; only one tree in five hundred will possess such fissures, and on this one trunk only a square foot or so is occupied by the lichen.

The lichens are of some importance in woods and forests, but they are especially interesting in the flora of rocks and stones. In a new wall or dyke, the stones show their natural colour, but this only remains for a very short time. Weathering begins, and a series of successive vegetations soon covers the entire surface.

The first stage of weathering is largely assisted by Bacteria, which seem able to disintegrate some of the salts of which the rock is composed. Next come the Lecidea lichens. Some of these are almost indistinguishable to the naked eye, and consist of scattered tiny stains of lichen substance. Others form a nearly continuous powdery crust not close enough to hide the stone colour. The best developed kinds entirely hide the surface, and form circular patches broken up into little flat-topped pieces amongst which are the cups. The second, or Lecidea stage, is very soon followed either by Parmelias or by Mosses. The Parmelias extend over the surface already partially worked over by Bacteria and Lecideas, and form the grey circular rosettes already described.

On dry basalt dykes, Rhacomitrium and other mosses soon begin to grow amongst the Parmelias. Other lichens also, Cetraria aculeata and Cladonias fix themselves between the stones where débris and moisture accumulate. Thus even at this point the wall is by no means a barren useless desert, but is almost entirely covered by an actively assimilating vegetation, which, moreover, affords shelter and livelihood to a variety of insects and 
other animals. Later on, the grasses or heather around, gradually creep up the sides, or fix themselves on the wall top.

In ordinary lowland districts, the process is a little different. The grey Parmelias are common enough; but very often little moss tufts take their place, and occupy the surface already worked over by LecanoraLecidea. These mosses belong to many different genera, Ceratodon, Tortula, Bryum, etc. As described on p. 258 they are followed by other mosses, and eventually colonised by flowering plants such as Sagina procumbens. Very soon grasses begin to grow between the stones or crevices; they spread downwards from above, and also creep up from below until the stones are almost wholly covered.

In very wet places stones and rocks have a different flora, composed generally of algae of one sort or another. A green stain is very common on damp buildings especially at the base of the wall. On certain building stones it always occurs before the house is dry ; but its presence is an infallible sign of damp in old-established houses. The algae which produce this stain are not always the same; but Pleurococcus vulgaris, Hormiscia and Rhizoclonium seem to be the most common. Occasionally one finds on damp walls beautifully rustyred tufts about a quarter of an inch in height; they are often passed over as old and dead mosses, but are really composed of an alga, Chroolepus aureus, which is exceedingly beautiful under the microscope.

Although, in the preceding examples, the flora of rocks and stones has been taken chiefly from walls and dykes, rocks in old quarries, boulders and cliffs show a very similar series. Waterfalls in wooded places show a bewildering variety in vegetation. Lichens, Liverworts, 
Mosses, Algae, like Rivularia or Diatomaceae, entirely cover every particle of the stone-surface; not a square inch is without vegetation which is at work assimilating and accumulating material.

All the organic matter so formed is utilised in some way. It may be carried off by the brooks and trickles of water, and assist in enriching the silt brought to the low grounds by the rivers; or it may be used as food by the minute animals which are devoured by fishes and birds. The importance of the rock and stone flora, however, lies in its having been an essential preliminary to other forms of vegetation. In all probability nothing could ever have grown on lava-flows, rock-falls and the like, if it had not been for lichens, mosses, algae, and other minute and little known forms of vegetation. 


\section{CHAPTER XIII.}

\section{MOSSES AND LIVERWOR'TS.}

THE mosses and liverworts occupy a very isolated position in the plant world. They differ greatly in appearance from the Fern alliance and are yet exceedingly unlike the Algae and Fungi.

Specirnens of some sort of moss may be found in almost every kind of country, for mosses are adapted to every sort of climate and soil. The little black alpine, Andraeas, grow upon boulders and rock under conditions of extreme exposure; and although they do not quite reach the high altitudes attained by some alpine lichens they are almost as hardy. Alpine streams and waterfalls have an abundant moss and liverwort flora; most peat bogs are formed by the action of Sphagmum. Both mosses and liverworts occur on moors, about the roots of heather, and in pastures, especially when the soil is clayey. Others form a characteristic and important constituent of the "wood-floor," where the graceful Thuidium tamariscimum and other branching, feathery Hypmums of many different varieties, often cover the ground under the trees with a network of green fronds. Some are even submerged plants. Fontinalis antipyretica is found growing under water on stones and rocks in rapid streams where, in order to maintain its position, it has to resist the full strength of the current during floods. The liverwort Riccia fuitans again is entirely 
independent of the ground and floats upon the water like Lemna or the Florida Hyacinth. Other specialised mosses are found on dry-stone walls, on tree trunks and branches by the seaside; and in the tropics special forms occur in great abundance, and extraordinary variety. Even screes of rolling stones are often attacked by a few mosses. There is, in fact, scarcely one single vegetation in which mosses are absolutely wanting. Yet it is only in the peat, in the barren tundras of Siberia, Arctic Canada and Europe, and perhaps towards the summits of alpine rocks that they can be considered as of first importance. In all other positions they have a subordinate part to play the exact nature of which has not yet been made quite evident.

They are never tall plants. The largest species have a prostrate, branching habit; but scarcely any are more than a few inches in height. This, however, depends upon a very simple peculiarity in the stems. Whereas ferns and flowering plants are able, in every case, to raise water within the stems, mosses and liverworts are without an efficient vascular tissue, and most of the water ascends on the outside of the stem. The leaves are small and numerous; and along with certain special hairs which are found on the outside, form capillary passages by which the water rises. Such a method can only be employed with low-growing closely-set plants. It is utterly unsuitable for tall erect species. This has been well expressed in the following "verses" by Carl Schimper:

Empfindlich für das feuchte

Wie für des ortes Leuchte

Was Wurz' und Stengel leisten

Gleich siehst du bei den meisten

Was die geheim auch mischen,

Sie können nicht erfrischen 
Die Kargen Wasserfasser

Moos welkt im Glase Wasser,

Die Blätter sind die Leiter,

Und aussen geht es weiter.

Though as Göebel very truly says they are schauder halfist considered as verses, yet they are none the less a true description of the way in which water ascends.

Even in cases like Sphagnum, where there is a sort of water conduction in the stem, the tissues are only on the outside, and consist simply of large empty cells with pores to allow the water to enter, and strengthening bands to give these cistern-cells rigidity enough to uphold it.

The life-history of a moss or liverwort is quite unlike that of any other plant. The moss with its leaves and stems absorbs water and mineral matters by means of rhizoids which in their action resemble root-hairs. It has no real roots. Most of the water and mineral salts necessary for its existence is probably obtained from the rain, which has always dust particles in solution, though the rhizoids also absorb food material. The sexual organs are the male "antheridia" and female "archegonia," which are found either clustered together near the top of the stem or arranged along the branches. The male organs are generally pillow-shaped, stalked sacks containing many male spermatosoids. They open at the top, through the cells in this part of the antheridinm, becoming gelatinous. The spermatozoids swim in the film of water covering the moss by means of their two actively lashing cilia, and seek out the female organ, or archegonium. This is a shortly stalked, rounded body with a relatively long neck. The female or egg cell is found in the base of the archegonium, and above is a chain of disorganized 
gelatinous cells down which the spermatozoid makes its way. The gelatinous matter contains cane sugar which attracts the spermatozoid.

After fusion of the egg cell and spermatozoid, the fertilised egg so formed begins to develop. It grows into a long stalk ending in a brown or yellowish green sack, the capsule, full of spores. These spores are scattered by the wind. When a spore falls to the ground it germinates and produces, not the moss as one would expect; but a preliminary state in the shape of a green mass of branching threads, very like a robust green alga. Upon this protonema, the moss stems arise as a series of buds which form the moss plant again.

The history of a moss may be written thus:

$$
\text { Moss plants }-\frac{\text { male, antheridia. }}{\text { female, archegonia. }}
$$

Eggs- $\frac{\text { capsules }}{\text { stalks. }}$ Spores-protonema-moss plants.

Thus the sexual stage of the life-history alternates with the spore stage. ${ }^{1}$ Protonemas may be produced from any part of the moss. The leaf, stem, capsule, or even its stalk may give rise to them. A protonema divided into pieces will continue to grow until it reaches the moss-forming stage. Thus the moss is not bound to follow the above history, but may continue its development by a sort of budding or non-sexual srowth.

The spores of mosses are, as has been mentioned, contained in a sack, the capsule, and are distributed apparently by the wind. These capsules vary greatly in shape and in structure. In such forms as Funaria

${ }^{1}$ This part of the subject will be found exhaustively treated in all English text-books. 
and Hypnum the capsule has when young a solid core. The spore-forming layer surrounds this central part and is separated from the outside wall by a very loose tissue containing many air-spaces which will provide the developing spores with oxygen. The capsule opens

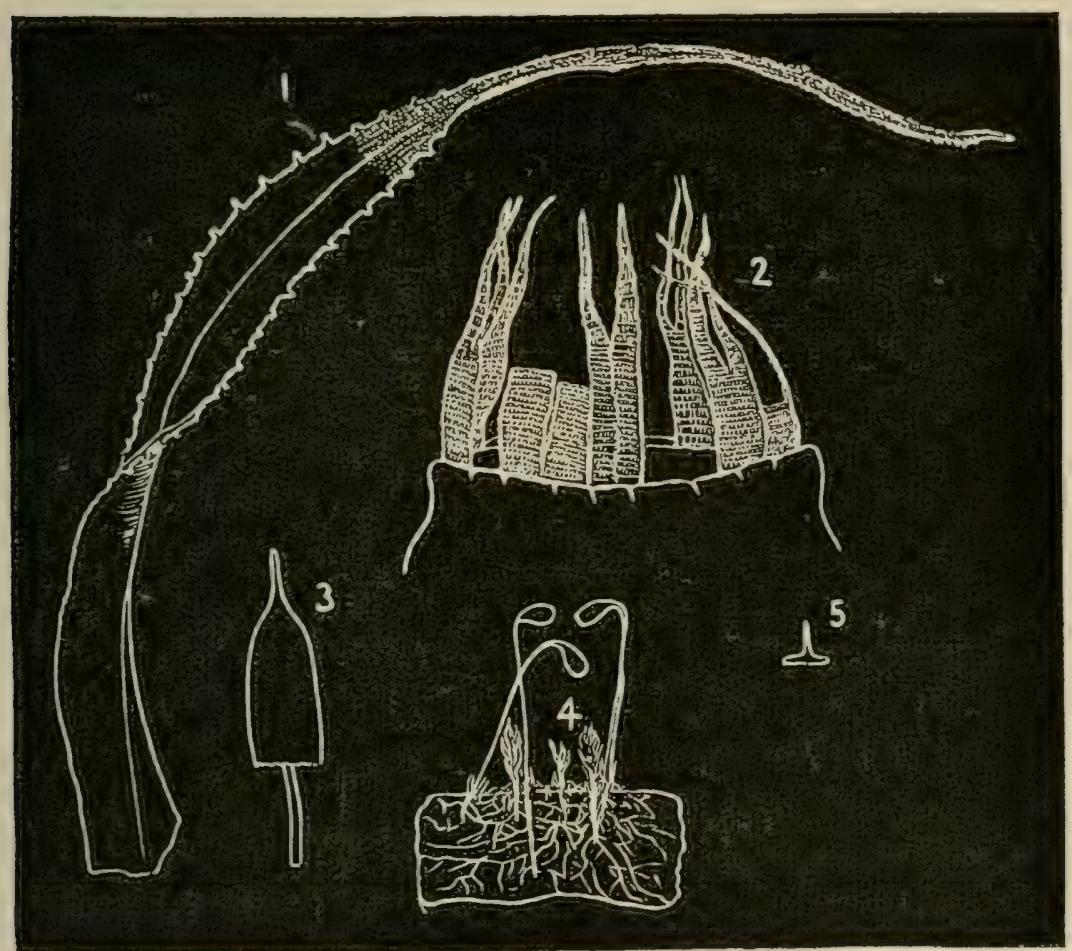

FIG. 32,-Mosses. (1) Leaf of Rhacomitriım. (2) Peristome teeth of Campylopus; several have been broken off fur the sake of clearness. (3) Hood or Calyptra (archegonium wall) of Encalypta. (4) T'uft of earth formed by a species of Bryum to show the interlacing of rhizoids (the stems are very much closer together in nature). (5) Lid or operculum of Campylopus capsule.

at the top only. There are three coverings. Two of these protect the capsule when young and are thrown off when it is ripe. These are (I) the "calyptra," a sort of hood and often covered with hairs, which is the upper part of the archegonium, and (2) the "operculum," a lid which fits on to the top of the capsule. The third 
covering is retained and is able to open and shut automatically according to the dryness or wetness of the atmosphere. In Funaria and most mosses this latter covering consists of (3) a series of peristome teeth, which are triangular or of the shape of a segment of a circle. These teeth are hygroscopic and curl inwards in wet weather but twist outwards in dry weather so that the spores can escape. Even, then, however, the spores are only scattered if the capsule stalks are vigorously shaken.

Polytrichum differs in having the central parts of these peristome teeth joined together making a circular white membrane. The spores can only escape through the pores between the teeth; and will, obviously, only escape in dry weather, and in small numbers. Thus the scattering of the spores takes a much longer time in Polytrichum.

Mosses generally grow in one of two ways. Either the stems are erect with very few branches and are closely set in little tufts as in the case of most mosses found on walls, or the branches are prostrate or curving over and finely divided in a feathery manner like the Hypnoids or mosses found on the soil in woods and upon tree bark. There are one or two exceptions such as Fontinalis and Climacium which will be separately mentioned, but the vast majority grow in one or other of these two ways.

The tuft-mosses on walls are especially interesting. They begin to grow upon the mortar between the stones or upon the remains of lichens which have. prepared a footing for them; and on any old wall there are generally quantities of these little tufts, consisting of very small upright stems with closely set leaves crowded together. If you break the tuft away from 
the stone, it will be found that there is a thick pad of earth upon which the stems are growing. This may be an inch and a half in thickness. It consists of soil, fragments of leaves, etc., held closely together by a densely branched network of reddish-brown hairs, the rhizoids or absorbing part of the moss.

Many small insects and other creatures find shelter in the little moss-tufts, and their bodies also occur in the earth. All this accumulation is due to the work of the moss. Every season's dead leaves, and any dust particles blown upon the tuft or brought to it by rain water, are retained for the nourishment of the plants. Even as regards strength, the manner in which these rhizoids can hold together and attach to the wall the weight of an inch and a half of earth, is remarkable. In fact, the rhizoid network is a much more efficient arrangement for manufacturing leaf-mould from its own leaves, than the arrangement of the Stagshorn Fern so often described in text-books. But it is so common an object that it seems to have escaped notice. The leaves vary according to the species. In one common type each leaf ends in a white transparent hair which will intercept a rain-drop and guide it down to the base of the leaf. The water then trickles in between the leaves, or rather what is left of it does so; for the most of it is absorbed by the broad spoon-shaped leaf, as it passes inwards. In other upright-stemmed moss-tufts, the leaf itself narrows into a fine point. But further information as to the shapes of the leaves must be looked for in such works as Dixon's Handbook of British Mosses or Hobkirk's Synopsis.

Upon such a moss-tuft, a flowering plant, the Sandwort, Sagina procumbens, is very often to be found. It has small whorled leaves and a system of horizontal 
runners rooting at the tip, as well as long horizontal roots which traverse the moss turf in every direction. It has also fleshy leaves, so that it can resist dry weather, during which on account of its situation no moisture reaches it.

Generally, however, other mosses of the second group, with a prostrate creeping habit, cover over these tufts of Didymodon, Bryum, Dicranella, or others. Except for their habit of growing on walls and forming dense turf underneath, they differ in every respect from the upright forms. Generally, they produce circular or oval patches, because the branches grow out from a common centre. These branches give off numerous branchlets, which are arranged in a pinnate or feathery manner; and, from the under side of all the branches and their divisions, little bunches of brown absorbing rhizines are given off, which fix themselves on the dying mosses below, and absorb whatever they can. When a particular branch has grown a certain distance from the common centre, the older part of it begins to grow brown and decay; then it is attacked by younger branches, which, beginning near the centre, curve over the older ones, and eventually extend beyond them on to a fresh part of the wall. These younger branches are in no way particular, and attach their absorbing rhizines to the parent branches below, or to any other likely material which they can reach. In fact, in most cases, it looks as if these branches were directly parasitic upon the older ones. These branching plumose feathery mosses, belonging to the old genus Hypnum, now subdivided into numerous sub-genera Brachythecium, Plagiothecium, Eurhynchium, etc., generally occur in woods, and especially in wooded lynns or ravines, where they are important constituents of the "wood floor." They 
reach their best development and are in fruit in early spring, generally in the months of February, March, and April in Scotland.

There is an excellent reason for their fruiting at this early season. The dead autumn leaves have been exposed to rain, frost, and the attacks of fungi during the winter, though the fungi seem to attack chiefly the leaves of the previous year, and what remains of those of former seasons. This "autumn fall," which consists chiefly of leaf-stalks, mosses and lichens from the branches, broken-off twigs and bark, and fallen branches, is thus ready for the attack of the mosses, which grow very rapidly covering it with a feathery moss carpet. The mosses can thus get in their "flowering" period and distribute their spores before the ground is covered by the leaves and branches of the Hyacinths, Primroses, and other wood plants. The stalk of a moss capsule is so short that the spores could not travel any distance, if they were distributed when the wood is occupied by other plants. Many of these woodland mosses such as Hypmum splendens and Thuidium tamariscimum, are exceedingly beautiful. The frond is generally concave below in every direction, and sometimes resembles a fern frond, sometimes an ostrich feather, and occasionally, the branching of a cypress or cedar. The leaves are small and numerous, and show considerable variety under the microscope, but they seem generally intended to retain any moisture which falls upon them.

Under the conditions in which they live they may be covered over by drifting leaves; but in such a case branches from the moss grow up towards the light and then curve out in the usual manner. This is the reason of the very peculiar growth of Thui- 
dium tamariscinum. Horizontal branches in a very moist wood, boulders by a stream, and the roots and lower part of the tree trunks are all specially favourite situations for the growth of mosses. Sometimes they grow only on those parts of a trunk which are kept moist by the rain water trickling down from above. In specially favoured positions, however, the trees will often show a very complex moss flora on their barks. Patches of this bark flora will be found on examination to consist of many different kinds of mosses, liverworts, lichens, and sometimes of fungi and algae in addition. Probably these plant groups are in some degree dependent upon one another for their existence; but their precise relations have not as yet been determined. Amongst the most characteristic of these bark mosses are Hypmum cupressiforme, and the most conspicuous of the Liverworts is the dark reddish-brown Frullania tamariscini.

But it is not only in the peat bogs and in the moist atmosphere of woods that mosses are to be found. Many mosses occur in very dry and exposed places, where drought, wind, and sunshine alternate with mists, heavy rain, and severe cold. Mosses are, as a rule, very tenacious of life. They dry up easily, and some can be kept dry for over thirty years without losing the power of becoming fresh and green when they are again exposed to moisture. Thus, a dry and withered-looking moss tuft may be torn away by the wind and blown a very long distance without injury. If it comes to rest in a favourable situation it will throw out its root hairs, and proceed to grow. Many of the mosses have also very distinct arrangements for adapting themselves to periods of drought and exposure. The leaves of Polytrichum, of Rhacomitrium, 
and of Andraea, are especially interesting in this respect.

Those of Polytrichum have been very well described by Kerner in his Natural History of Plants. The figures show clearly how the escape of moisture is prevented, as far as possible, in dry weather; and how the green cells of the upright plates which run longitudinally down the leaf, stand out in moist weather to get the greatest possible amount of light.

Rhacomitrium leaves generally end in long fine points. In the dry state all the leaves contract upon the stem, and the plant seems entirely covered by woolly hairs, which are the leaf-tips. They look very like the woolly hairs characteristic of desert plants, and they fulfil the same purpose, that of keeping in moisture, and, probably, also of keeping out cold.

Fontinalis antipyretica is altogether different from these wall mosses. It grows in rapid streams, especially in mountain streams, and is often found in great numbers and mixed with liverworts and other mosses. The leaves are arranged in distinct rows, and in such a way that they shelter one another from the current. The hairs, by means of which it holds to the stones, are also well worth examination.

Climacium, a "wood-floor" moss, looks like a miniature tree with an erect stem and several branches.

To all British and Irish students peat-moss is certainly of great importance. In Ireland bogs occupy something like one-seventh part of the surface. In Scotland there are many square miles of moss which are still entirely uncultivated, and yield a very scanty pasturage to sheep, or to wild animals. We may suppose the formation of a peat moss to have been as follows, though it must not be considered that any peat moss 
will show all the characteristics that are here mentioned. Some are of very modern origin; and, unfortunately, in Scotland very few have been scientifically examined.

When the ice-sheet retreated polewards, the land must have had a very desolate appearance. Perhaps the following quotation from Bernacchi gives a fair idea of the landscape as it would then present itself, though this is taken from the Antarctic Continent. "Gravel and pebbles were heaped up in mounds and ridges. In some places these ridges coalesced so as to enclose basin-shaped hollows. Bleached remains of thousands of penguins were scattered all over the platform, mostly young birds that had succumbed to the severity of the climate."

"The scene before us looked inexpressibly desolate." "No token of vitality anywhere, nothing to be seen on the steep slopes of the mountains but rock and ice." Upon this exposed ground still subject to a severe arctic climate, first such little Arctic plants as Salix polaris and Betula nana began to grow. In wet low-lying places, there would then develop a marsh flora consisting of Rushes and Reeds such as Phragmites and Ranunculus aquatilis, or of similar swamp or marsh species. If the ground became permanently waterlogged, mosses would soon begin to form upon the remains of these Reeds and other aquatics. Amongst these mosses Sphagnum, the peat moss proper, would soon take a prominent place. The structure and growth of this plant is extremely well adapted to its mode of life, and enables it to choke out almost every other kind of vegetation. The stems are upright, and grow in closeset ranks so that the moss forms a continuous cushion generally saturated with water. The structure both of the stem and leaf is well adapted to retain any water 
that reaches them. There is, in the centre of the stem, a thread of strong wiry cells; and round these, forming a sort of bark to the stem, is a cylindrical mass of water-absorbing cells of a peculiar character.

They are large, empty, and strengthened by woody bands, which cover the inside of the cell and give it

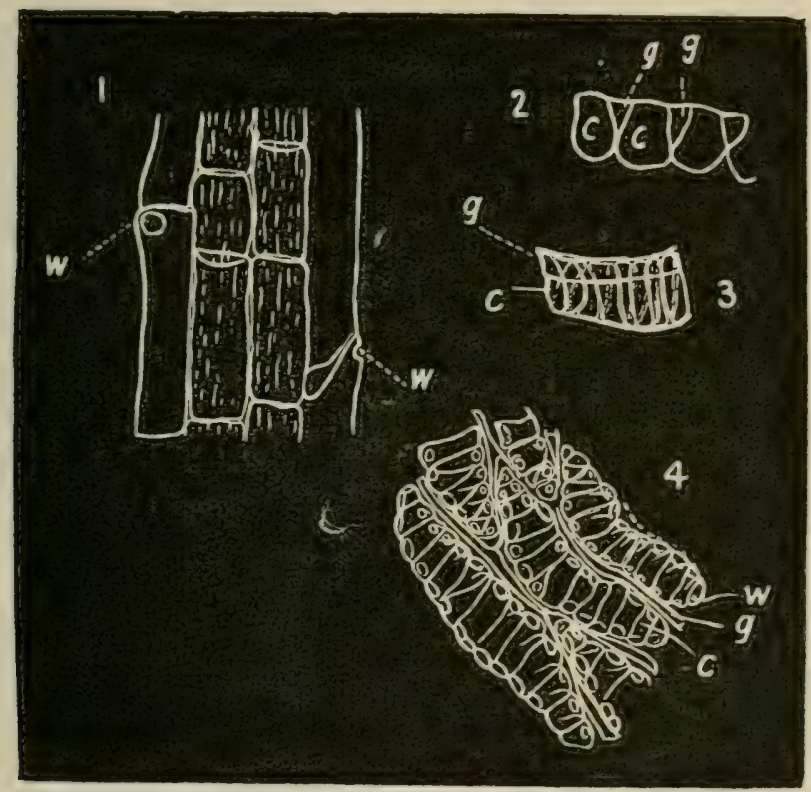

Ficr. 33.--Pfa " Moss, Srhagnum. (1) Part of s em highly magnified, showing cistern cells on the o itside. (2) Leaf in transverse and (3) in longitudinal section. (4) I.eaf seen from above. (o) Green cells. (c) Water-holding or cistern cells. (w) Pore by which water enters.

sufficient rigidity to support itself when full of water. Each has also a pore to admit the water. These cells act, therefore, like a circle of capillary tubes placed round the central part of the stem, and raise the water to the leaves, which possess similar cistern-like or waterholding cells. The cistern-cells are very large as compared with the green assimilating cells placed above and between them (see Fig. 33). Branches are given 
off at every fourth leaf, and the stems die off at the base. If there is sufficient moisture they are always growing upwards. Thus, if one remembers that these stems are placed closely side by side in a sort of cushion, and that this cushion is able either to float in water or to grow on saturated mud, it is clear that there is no limit to the peat moss formed by the Sphagnum, provided always that there is no lack of water.

Peat mosses of extraordinary depth are known. Some of those in East Prussia are from I $\$-30$ feet deep; and even our own Scotch mosses may be 20 feet deep or more. The growing Sphagnum cushion very often floats on the water or on the liquid mud. When heavy rain has been falling for a long time, water may accumulate in great quantities over the dead peat, and under this cushion of growing Sphagnum and other plants. It sometimes happens in these circumstances that this living crust bursts, and a deluge of peaty water or mud overflows the surrounding country. This took place not very long ago at Killarney; and similar peat floods have been recorded elsewhere. ${ }^{1}$

Generally speaking, the Sphagnum moss is not continuous. There are firmer places where the neighbouring vegetation obtains a footing. Such plants as Sweet gale (Myrica), Birch, and Heather, are to be found in most peat bogs, as well as a sort of superficial flora, which extends over the drier parts, but whose roots do not penetrate deeply into the peat. This flora includes Sundews (Drosera) and Cranberries (Vaccinium oxycoccos). As the supposed Sphagnum moss developed continuously in the same place since the glacial period, it has been

I Rathmore moss, where 200 acres overflowed and nine persons were killed in 1896, Crowhill bog at Keighley in 1824, a Lancashire moss in I745, an 1 a bog of 40 acres at Charleville in 1697, are the best known examples. 
successively inhabited by the neighbouring vegetation of all subsequent periods, and the remains of the latter occur in the peat. There are in the lower layers, for instance, roots and trunks of Pinus sylvestris, sometimes in great quantity, showing that at that time Pinewoods were the dominant vegetation. Higher up in the peat there is Bog Oak, which is found at first mingled with the Pine, but entirely by itself in the higher levels. Finally in the uppermost layers the remains of the present neighbouring flora may be found. Thus, from the evidence of the peat, we see that the Pine forest, now characteristic of Norway, and probably corresponding to the Sylva Caledonica of the Romans, was replaced by Oak forests, which are known from historical evidence to have once occupied most of the Scottish lowlands (see Niven). This oak forest has been replaced by plantations of an artificial character, which are now leaving traces of their occupation in the peat. On the Continent, polished-stone implements have been found in part of the Scotch-fir layers, and remains of Roman weapons are of common occurrence in the Bog-oak deposits. Bones of extinct animals, and even of man, seem to be preserved with extraordinary little injury in peat. This is on account of the very peculiar character of a peat moss. Being always saturated with moisture, oxygen cannot penetrate, and neither the ordinary bacteria of putrefaction, nor worms and other animals are able to exist. Hence the progress of decomposition is arrested; and, instead, humic acids make their appearance, and these are strongly antiseptic. Thus peat is an accumulation of partly decomposed vegetable material. It consists mainly of carbon, and may contain from I-2 per cent. nitrogen, 0-4 per cent. calcium, but generally has very 
little of either potash or phosphorus. In its natural state it is one of the worst soils known and very few plants are able to develop upon it. Of those few, all seem to possess a mycorhiza or fungus-servant. The Sundews (Drosera) and Bladderworts (Utricularia) obtain most of their nitrogenous food from the insects which they catch.

If peat is dried and broken up so that air and light can reach the fragments, then the humous substances vanish; the carbon becomes carbonic acid, the nitrogen becomes nitric acid, and the soil becomes a valuable and useful material. Orchids, for instance, are always grown on peat. The drying is, however, very difficult, as the substance is peculiarly porous (about 40 per cent. only of a cubic foot of peat is solid matter. The rest of the volume is made up of pores, in which the water is strongly held). (See also p. I I 7.)

There are several methods of reclaiming a peat moss. Generally it is first drained, and then, after sand and manure have been applied, grass seeds can be sown upon it. It is even possible to grow pine-trees upon drained peat-mosses. Sometimes the upper layers are burnt and treated with lime or estuarine mud, so that a new surface is prepared. Near Glasgow a great deal of useless peatbog has been brought under cultivation, and made to produce excellent crops by covering the surface with the town refuse.

Many attempts have been made to utilise peat. It is still a common fuel in many parts of Scotland and Ireland, but cannot compare with coal at present prices. Large quantities are imported from Holland as peatmoss litter, although there is plenty of material in this country. Horse-rugs, paper, mats, brushes, and eren 
cattle food have been prepared from it. The last mentioned is a very fine peat dust saturated with treacle. Theoretically these peat mosses ought to be a source of great wealth, but, so far, very little use has been made of them in Britain. 


\section{CHAPTER XIV.}

FERNS, FERN ALLIES, AND FOSSILS.

In past geological periods, Ferns were the dominant vegetation, and were very widely distributed; but now they never occupy large areas, and, though common in subordinate positions, they are of little importance. In Scotland there are often great stretches of Bracken on the lowland sheep farms, which seem at first to be a special association of plants in which the fern retains something of its old supremacy; but this Bracken formation is generally found on parts of the country which were in all probability formerly covered either by light oak scrub, or by pine and birch; and, probably, it represents woodlands from which the trees have been removed. The limits of altitude to which the bracken extends are very nearly the same as those of the Pine.

On the whole, Ferns and their allies are decidedly a decaying family, driven from the best situations by better developed forms. In Britain they generally occur in the deep shade of well-grown trees, and in a moist atmosphere, though there are several exceptions. The little Wallrue (Asplenium muta-muraria), and sometimes Maidenhair Spleenwort (Asplenium trichomanes), flourish on the stones of bridges and walls, where they are much exposed to drought. Ceterach officinarum is also a hardy fern, able to exist in very dry situations. 
None of these three, however, are like the ordinary ferns in leaf and general habit. The Wallrue has greatly reduced its leaf surface, and does not, therefore, lose very much water by transpiration in dry weather. Ceterach has a special power of rolling up its leaves so that the dense, yellow-brown woolly scales on their lower surface entirely cover the plant and hinder the escape of water. That most of the family thrive best in moist, shady places has been well shown by Kerner von Marilaun, who compares the dry arid plateaux of Persia with the Blue Mountains in Jamaica. In Persia there is a ten months' dry season, and no ferns are to be found in a district 5,000 square miles in extent. On the Blue Mountains where rain falls on almost every afternoon throughout the year, 500 species of fern occur, and fifty different kinds may be found in a hundred paces.

The reason of their being usually confined to moist places is explained by the structure of any common fern, such as the Male Fern (Lastrea filix-mas). The leaves are large and much divided in a feathery (or pinnate) manner. They extend over a large surface. Each leaf is clearly intended to form a segment in the broad circle of drooping fronds, which will intercept as much as possible of the scanty light that falls upon it. But these leaves are thin and soft in texture; they show scarcely any protective arrangements against sun, wind, or drought. The epidermis is not, or is only very slightly thickened, and it contains green chloroplasts, showing that it is scarcely at all specialised for the defence of the frond.

When young the leares are very carefully protected. The whole frond is rolled up into a spiral coil, and each of its leaflets is also rolled towards and under 
the main stalk. Many minor details in the shape and attachments of these leaflets can be understood, if a half unfolded leaf is carefully examined. A dense mass of overlapping golden-brown scales covers its entire surface. These scales keep off rain, prevent injury from cold, and are sometimes very necessary to keep out small insects which occasionally destroy whole fronds by colonising the bud (see p. 275).

Wherever the plant grows under different conditions, the leaves vary accordingly. Thus, in Ophioglossum the leaf is very like that of the grasses amongst which it grows. Hart's Tongue (Scolopendrium), often found on sloping banks, in Devonshire lanes, and elsewhere, has a broad simple leaf which hangs out over that of other plants. Both the Common Polypody and the Hard Fern (Blechmum spicant) have very slightly divided leaves; the latter is a hardy species often found in the open, and the former prefers dry stone dykes. On the other hand, the British Filmy Ferns show an extraordinary resemblance to some hypnoid mosses, and they grow amongst such mosses under alınost identical conditions.

In the course of its development, the leaf gradually unrolls itself, and its stalk is at first almost vertical. If it is growing in the ordinary damp atmosphere of a wood, the leaves then droop over into their natural position; but if the place is dry and exposed, they remain more or less erect, so that the light falls chiefly on their edges, and not upon the whole upper surface.

Fern stems vary greatly in size and appearance. The erect, unbranched, pillar-like trunks of the treeferns are sometimes 80 feet in height. The stem of the common bracken is buried from 6 to i 8 inches deep below the surface of the soil, so that its leaf 


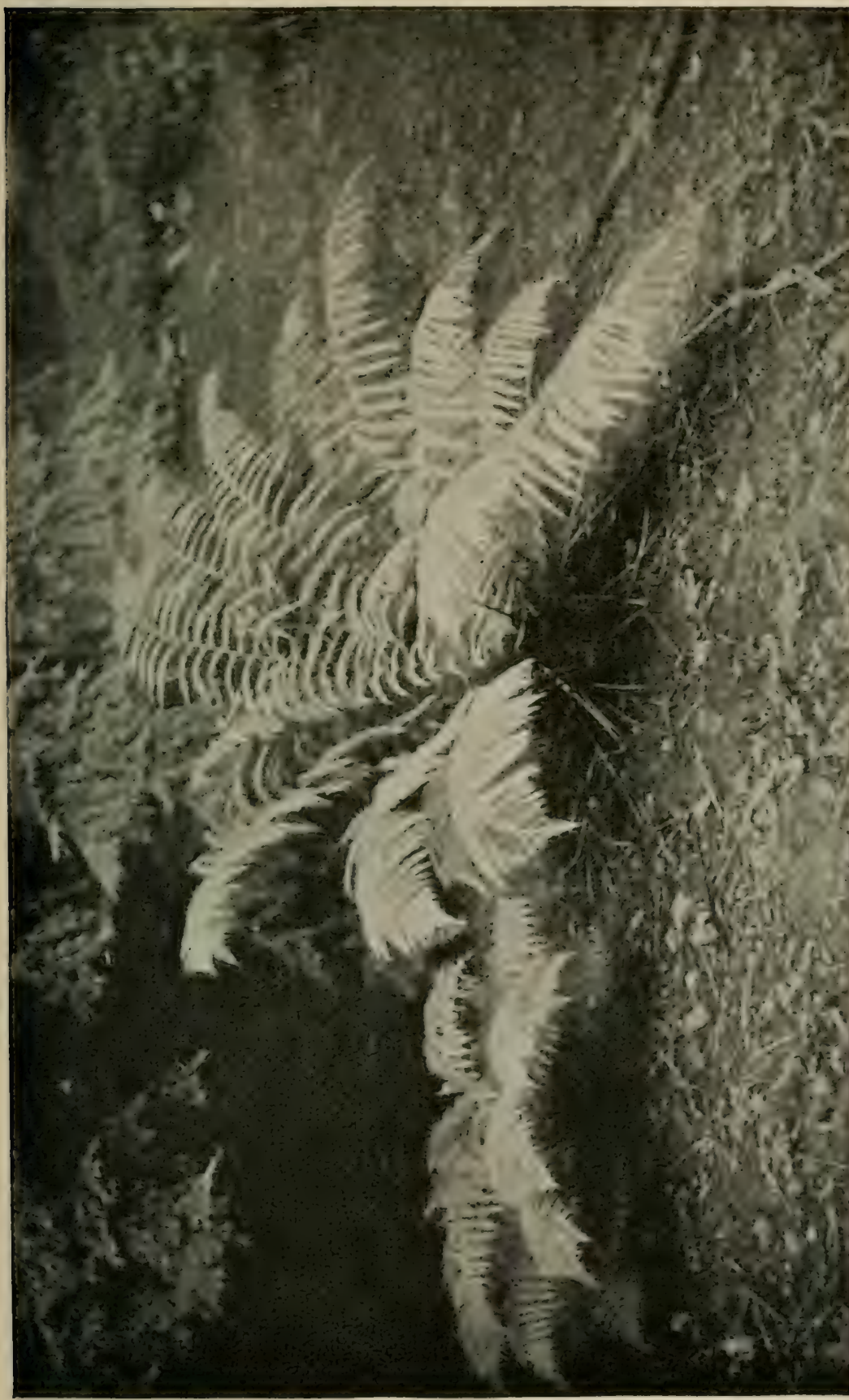

它 
stalks (which show the "oak") act like stems and display the green leaflets. The stem of the Male Fern lies obliquely on the ground. The Common Polypody rhizome creeps amongst the crevices in stone walls, and on the bark of trees, and the rhizomes of the Oak and of the Beech-Fern grow horizontally through the loose, light leaf mould, under the trees in woods. Many fern stems seem, therefore, intended to creep under or above the ground, so that the roots and leaves are formed in a new place every season. They are, in fact, generally colonising rhizomes, and show many interesting adaptations to such a function.

Reserve food is often stored up in fern stems, and volatile oil, tannin, and resin are also found. These stems are often thickened so as to contain a large amount of the food-material, and they must be protected against the attacks of animals, especially against insect larvae. Hence these fernrhizomes are almost always thickly covered by a brownish, or golden-yellow fleecy covering, which consists of closely-overlapping scales. It was a piece of a fern-rhizome, with four leaf stalks attached to it, which gave rise to the "Scythian lamb" myth. The ingenious Scythians apparently passed this off on the tourist of the period, as a sort of plant which grew into an animal; or animal which became a plant; and the subject was much discussed in the Middle Ages. Milton refers to this plant apparently in the sentence:

"Fleeced the flocks and bleating rose, As plants."

Besides this woolly or scaly covering, fern-rhizomes 
are protected by other contrivances, of which some are rather unusual. In Tree-Ferns and others, tough and wiry roots are produced in great quantities from the base of the leaf-stalks, and form an efficient covering to the stems. In the Male fern the leaves wither nearly to the base in autumn, but the bases, or stumps, are left in a dry, withered, and fibrous state. As the entire rhizome is almost wholly covered by these leaf bases, it is not easy to get through them to the stem itself. In addition, there seems to be some unpleasant taste in the leaves of ferns, for they are but seldom eaten by animals. The Male-Fern (Lastrea filix mas) also contains special cells secreting filicic acid, as well as aspidin, volatile oil, and tannin, etc. The drug obtained from it, which has a faint disagreeable smell, and a bitter and nauseous after-taste, is efficient in dislodging tapeworms. There are also peculiar red, or redbrown, hairs on young bracken-leaves, which are supposed to attract ants who may keep off caterpillars and other destructive insects. The bracken is distributed almost all over the world, and this protection would be useful in places where leaf-cutting ants are abundant, but it can scarcely be said that the bracken is myrmecophilous. According to Ludwig, old leaves which have lost the hairs are sometimes almost wholly devoured by the grubs of a small wasp (Strongylogaster cingulatus), which passes the winter in the bark of the Scotch Fir (Pinus Sylvestris).

In other respects also, the Fern is well adapted to moist and shady woods. The reproductive bodies are on the under-side of the leaves and therefore cannot be injured by rain or by sun. They consist of little brown clusters of spore-cases or sporangia, which are lens- 
shaped, or like a watch in outline. Each sporangium contains some 64 spores. A strong ring of thickened cells runs very nearly all round the wall of the sporangium. This ring is elastic and in the course of its drying up bursts the thin wall of the case. After bending backwards, it suddenly springs forward again, throwing the spores to a considerable distance. In some ferns the spore-bearing leaves are nearly vertical or much more upright than the others, which, of course, greatly increases the distance to which the spores are thrown.

There are little hairs at the base of the sporangium which probably secrete moisture and keep the cluster from drying up; and this is probably also the function of the white scale or indusium which entirely covers the clusters.

The spores germinate in light only and produce a flat green heart-shaped body, the prothallium, on which there are both male and female organs. The male or antheridia produce a great number of small spirally coiled antherosoids or spermatozoids each with a tuft of cilia at the apex. The female or archegonia are chimneylike structures with the egg cell concealed at the base. A drop of malic acid is secreted by the archegonium and attracts the spermatozoid which eventually passes down the chimney and unites with the egg-cell. The latter then begins to develop into a new fern. These prothallia can sometimes be found in quantity on fallen logs in woods. They are independent of the mother plant and have both green cells and absorbing root-hairs or rhizoids. Both the male and female organs are below and somewhat in front of the prothallium; so that they are to a certain extent protected. Although the antherozoids swim to the archegonium, it is found that a small insect, the Podura, one of the Springtails 
(Collembola), which occurs in moist and shady places, seems to increase the number of young ferns, for more egg cells seem to be fertilised when this animal is present. After fertilisation the young fern plant develops from the egg cell. It has a special sucker-like organ which extracts everything that is useful from the parent prothallium, which very soon dies away.

Thus the life story of the fern may be written as follows: Fern plant-spores-

$$
\text { prothallium }<\frac{\text { male spermatozoid }}{\text { female egg-cell }}>\text { ovum }
$$

egg-cell-fern plant (compare Moss, p. 256).

The chance of any one egg-cell becoming a fern plant will be seen to be as follows: As one to the number of archegonia on a prothallium, multiplied by the number of spores in a sporangia, multiplied by the number of sporangia in a cluster, multiplied by the number of clusters on a leaf, multiplied by the number of spore-bearing leaves on a plant. It is assumed that only one fern plant is produced by any living fern, which is a quite justifiable assumption, as the number of mature ferns in a country probably does not perceptibly increase. The chance therefore of an egg-cell becoming a fern is certainly not more than I to $2,000,000$, but the I,999,999 wasted spores are necessary, if one considers the multifarious dangers to which these spores and prothallia are exposed.

Clubmosses and Selaginellas - of which last there is one British species-are allied to the Ferns. They have rather thin, tough, and wiry stems, densely covered by leaves, and are generally found either amongst alpine plants, or on the peat in moorlands. Their sporangia are found at the ends of the branches and are placed in the axil of the leaves. These plants never occur in 
very large numbers and are not of much interest except from the geological standpoint.

The Clubmosses (Lycopodia) are generally creeping plants with upright spore-bearing and other branches. The spores are contained in small sporangia, placed above the leaves. The spores produce an underground tuber-like prothallium on which the antheridia and archegonia occur. The fertilised egg-cell of the archegonium produces a new Lycopodium.

A Selaginella is very like a Lycopodium in appearance but differs from it in having the spores differentiated into male, or microspores, and female, or macrospores. The sporangia open in two valves; the female spores, of which there are only four, are jerked or thrown off by a peculiar elastic contraction of these valves and one at a time. The male spores, which are rather numerous, are also thrown off in a similar manner.

During the coal-measures, Club-mosses were gigantic trees. Such a form as Lepidodendron must have been very like a specimen of Lycopodium Selago magnified to the height of 50-70 feet and a forest of such Clubmoss trees must have had a most peculiar appearance.

The Horsetails (Equisetaceae) differ altogether from the rest of the Fern-alliance. They have long underground or under-water rhizomes, from which rise the erect stems. The leaves are very small and are placed in circles along the stems. From each leaf circle a whorl of elegant drooping branches is produced. The main stem is generally surmounted by a close-set spiral of spore leaves. In some species, however, certain stems are barren and carry many green branches, whilst the spore-producing stems are not branched, and are formed before the others. The Horsetails are found in quite a variety of situations. Some, such as E. arvense, 
prefer the bare and barren soil of railway banks and shale heaps; others, such as E. limosum and E.palustre, live either in water or in very moist places. They do not seem able to hold their own on good soil, if other plants are allowed to extend over it.

The "flower" consists of very numerous spore-leaves which are peculiar in shape, and are on a much higher scale of specialism than those of the ordinary ferns and Clubmosses. The spore leaf has a short stalk and ends in a flat brown hexagonal or pentagonal top; when young these flat top-pieces fit together, forming an absolutely continuous surface over the stem; the sporangia, which are hung on the undersides of these tops, are thus thoroughly protected against rain, or other dangers. Very often the whole of the young flower is, in addition, covered by several series of leaf whorls, which become distant, and separate when the stem elongates.

The spores are scattered very early in spring; the Equisetum "flower" is one of the very first to appear ; when ripe, the spore leaves become slightly separated through the growth of the axis to which they are attached, and the spores are carried off by the wind. They have a very peculiar arrangement for distribution, an arrangement which is apparently entirely confined to this one genus. The spores have three membranes or cell walls. The outermost of these membranes or coats becomes divided along a line which runs spirally round the spore, and forms four ribbons, which are only attached to the spore at one spot. These ribbons are very hygroscopic, and they curl up, or uncurl and twist about, according to the amount of moisture in the air, so that the spore shifts its position, and has a better chance of reaching a favourable place for germination. The spores form a prothallium upon which antheridia 
or archegonia are produced. But the Prothallium is either male or female and forms either antheridia or archegonia, but not both. The fertilised egg-cell of the archegonia will of course produce the Equisetum.

From the preceding, it is clear that both spores and prothallia may be of different sexes; and it is also obvious that the difference between the sexes proceeds further back as the plant becomes more highly specialised. In the Fern and Clubmoss, the same prothallium bears male and female organs; in Equisetum the prothallium is male or female; in Selaginella the spore is male or female; in flowering plants we find male sporeleaves or stamens, and female spore-leaves or carpels. There is even a higher degree of differentiation still, for in dioecious forms such as the Walnut, the plant itself is male or female producing stamens only, or carpels only.

In the higher flowering plants the prothallium is almost entirely suppressed; the growth of the pollentube on the stigma is all that is left of the germination of the male spore; and in the ovule, the embryo sac probably corresponds to the female spore. Selaginella, and certain very rare Water Ferns show certain transitional states between a free prothallium and the reduced type found in flowering plants.

It will be seen that the chief importance of Ferns and Fern allies lies in their transitional character. Their past history is of the very greatest interest, because in the Devonian and Carboniferous periods, these Ferns and their allies were the dominant forms of vegetation. A Coal-measure landscape is very difficult to realise, and the following description must be taken as merely the writer's personal views.

The atmosphere was saturated with moisture, and the land covered with swamps of deep mud or ooze, 
interrupted by stretches of water full of the creeping rhizomes of living plants, and of decaying vegetation. The temperature was higher than it is in the tropical forests of to-day; and the continual mists produced a dim, shady light, such as that found nowadays in the

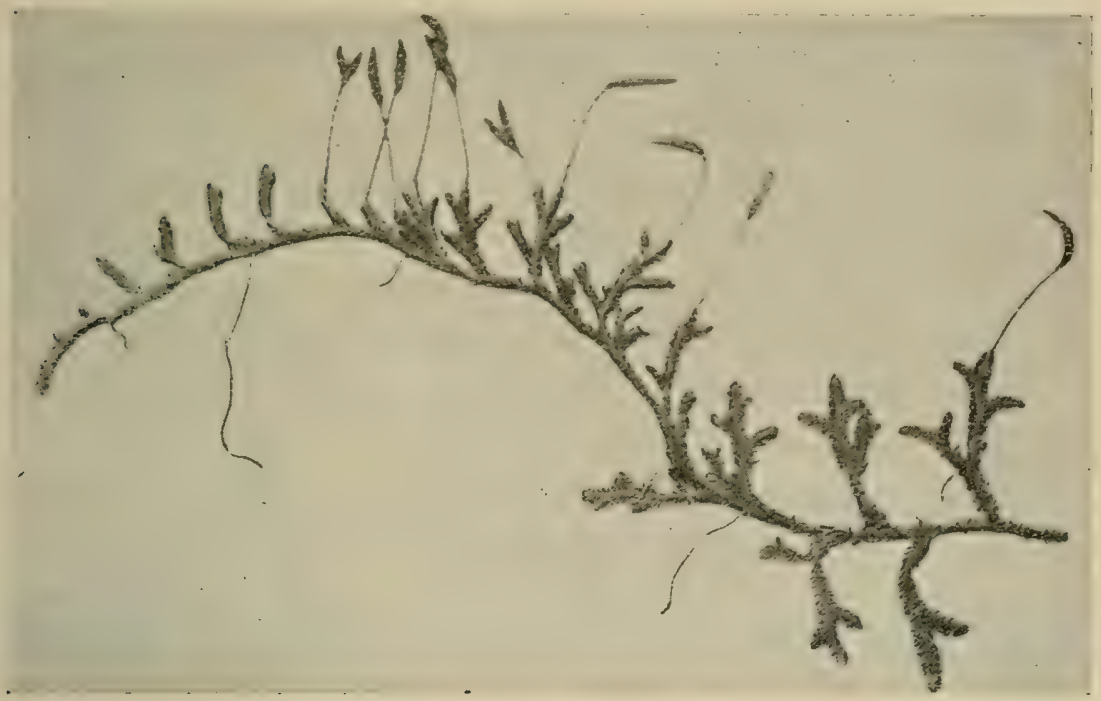

FIG. 35-A Clubsoss (Lycopodium clavatum). To show the root-bearing projections or branches below and the flowerlike clusters of spore leaves at the ends of the upper branches. Photograph from a herbarium specimen (collected, R. Hennedy, 1850).

places most frequented by ferns. In such a warm, steamy atmosphere, both growth and decay were exceedingly rapid. The spores, protected by the resin which they contained, did not decay so fast as the other parts. Our coal is, in fact, largely made up of spores of Fernlike and Lycopodiaceous plants, whilst the mineral, or mother of coal, represents decay-products and the shreds of bark and leaves. Through forest sivamps of this kind there meandered rivers, which deposited in their basins masses of vegetable pulp mixed with silt. These beds have 
been in course of time transformed into "cannel" coal. In what is now the Welsh coal basin, heat or pressure, or both, fused the carbonaceous matter and turned it into the hard, shiny, formless condition now called anthracite, which is the best steam coal for naval purposes. Ferns and their allies are therefore of great historical interest, although their importance to-day is by no means great.

Unfortunately, authorities on fossil botany differ very widely in their views as to the nature of many plant remains, and it is not possible to give a definite and clear account of the first appearances of any of the groups that are now in possession of the earth.

It is probable that the first living creature was of the nature of an Alga, because, to assimilate carbonic acid or form sugar, seems to require the aid of chlorophyll; and with regard to those few animals which possess green chlorophyll in their bodies, the green matter seems to be really an alga contained within the animal. The modern algae are confined either to water, or to the thin film of moisture which covers very wet rocks or soil, and they are unable to exist on dry land. The most probable guess as to the nature of the first dry land plant is that it was a Lichen consisting of an alga and a fungus living together.

Unfortunately, there is much uncertainty as to fossil Algae, Fungi, or Lichens, owing, no doubt, to their soft, fleshy character, which would always make their preservation a mere accident, not likely to occur at all frequently. Many fossils which have been named and described as seaweeds, turn out to be only markings of the soil due to all sorts of causes. For example, the casts of animal tracks, such as those of certain 
crabs, the tubes formed by sandworms, and the cracks of a drying clay surface (not to speak of oyster shells), have been described as algae. But if such a specialised type as the diatom is found in the Cretaceous period, and if Bacteria (on the authority of Renault), existed in the coal-measures, it seems at least probable, that algae must have flourished long before either of these epochs.

Before proceeding further with the geological history, it is interesting to see how vegetation develops on bare places in the present day. It must not be forgotten that the land has been very greatly altered by vegetation. The plants of the early geological periods had to develop on absolutely unworked soil. There were no surface moulds; no shales full of organic remains; but only barren igneous rocks, or limestones, and sedimentary strata scarcely altered by vegetable action.

At present, it is only new lava flows, such as those from Mt. Pelée and La Soufrière, or from Mt. Vesuvius, and, in a less degree, newly built stone walls and the screes or rockfalls of the highlands that can be compared to primitive conditions. It so happens, that an excellent description has been given by Comes of the gradual settlement by plants of the Vesuvian lavas. The first species noticed were Algae of the Pleurococcus group, and certain Lichens. ${ }^{1}$ These slightly disintegrated the lava, and by their decay introduced a slight percentage of organic matter. Mosses of different kinds next appeared upon this slightly prepared surface. Then came certain Ferns, and, still later on, Flowering plants, adapted to very

${ }^{1}$ Heer's Primaeval Flora of Switzerland gives an excellent and vivid picture of the succession of plants in central Europe. 
dry conditions, began to grow. It was only after some twenty years that a few woody shrubs could obtain a foothold on the lava. Finally, trees, and even true woods, were able to occupy the older flows. In the island of Krakatoa, it was also found that algae were the first to develop on the ashes and pumice stone, and so prepare the way for Ferns and Flowering Plants.

It has been shown in a previous chapter, that the succession of vegetations on bare rock or walls, whether by the seaside, along roads or at the summit of Highland hills, is almost always (I) Bacteria, ${ }^{1}$ (2) either Algae or more usually Lichens, (3) Mosses, and (4) Dicotyledons or Monocotyledons. Usually the Grasses (Monocotyledons) precede the Dicotyledons (see p. 25 I, 9). One can, however, in the screes of rough angular stones often found in corries, occasionally trace precisely the succession described for Vesuvian lavas: First Lichens ; then Moss ; and then Ferns. Grasses or perhaps Saxifrages come next, and it is possible that careful observation might show Birches growing on old grass-covered screes.

It would be interesting if we could find traces of a Moss vegetation preceding the Devonian clubmosses and ferns. This might have been similar to the present flora of the tundras of Siberia. Of such a moss period, there does not seem to be any record; but, whatever the precise affinities of the curious Devonian plants may have been, Ferns and their allies were certainly predominant at that time, and preceded all the flowering plants.

From the Devonian period the succession of vegetation

${ }^{1}$ It is, at least, probable that the ubiquitous Bacteria begin the process (p. I98). 
is fairly distinct. The Carboniferous was certainly the age of Lycopodiaceae. Lepidodendron and Sigillaria were enormous in size as compared with our own Clubmosses, but the similarity in habit is unmistakable. Apparently also fungi attacked their trunks, and bacteria disorganised the cellulose remains.

For the Permian, the Tree-ferns and gigantic Calamariae (an extinct family of Equisetaceae) may be considered as the most characteristic and important kinds of plants.

In the Triassic period, the Horsetails, or Equisetaceae, seem to have been relatively more important than they have ever been since ; but in Triassic and Jurassic times, Cycads were the dominant vegetation in almost every part of the earth where fossils of these periods have been discovered. The Araucaria, or Monkey-puzzletree, and the Maidenhair-tree (Ginkgo or Salisburia) seem also to have been abundant and are very widely distributed in Jurassic strata. Thus after the Horsetails obtained a very prominent position, they were set aside for other plants belonging to a more advanced family, the Gymmosperms. Although these pioneers of the Gymnosperms, the Cycads, the Araucaria, and the Ginkgo are true flowering plants, yet they are on the very border of the family, and the least specialised as regards their flowers and anatomical structure. Nevertheless they still exist, and the Cycadaceae contain some 75 species, and are widely spread in all tropical countries. The Monkey Puzzle (Araucaria) is still able to produce forests ; though this is only possible in the Chilian Andes which is a very out-of-the-way part of the world. Ginkgo seems to be almost unknown in a wild state, but it has been preserved by the priests of certain Chinese temples.

A sudden and extraordinary change occurs at the 
beginning of the Cretaceous or Chalk period. Instead of Cryptogams and extraordinary Conifers, one finds a whole series of well-developed Dicotyledons and Monocotyledons. These in leaf and stem closely resemble modern plants, and must have formed an essentially modern-looking flora. The Pine, Oak, Maple, Alder, Willow, Poplar, and even such shrubs as the Sweet Gale, are found in deposits of the Chalk period. There is some ground, too, for supposing that the complex interdependence of the plant and animal world with which we are now familiar was even then fully established. All the great groups of insects were in existence. Fossil butterflies are found in the same strata as certain Willows; and, at the present time, the caterpillars of the same genera find their food upon the descendants of these Willows.

After the Cretaceous period it is possible to distinguish representatives of modern floras. Dicotyledons and Monocotyledons had not only attained their supreme position, but they forthwith began to multiply, and developed into migrating floras, which drove one another all over the world, until the conditions of the present day were produced.

The Eocene flora of Europe contained forms which are closely allied to the tropical plants of India, and to the extraordinary vegetation of Australia.

In the Miocene period, the flora changes from tropical to subtropical, with many "American" types. Before the end of this epoch "Atlantic" and "Mediterranean" plants had made their appearance, and these became dominant in the "Pliocene" period, and have remained the most important European plants until the present day. Before continuing the history of vegetation through the Great Ice Age, it is important to note what 
has become of those vanquished floras, which once formed primaeval forests entirely by themselves.

The series of changes may be compared to successive waves of development, which either ingulfed the former floras, or drove them aside, out of the way, into places not worth colonising. In this respect, they have a certain analogy to waves of human migration.

IVe will assume the succession to have been Algae, Lichens, Mosses, Ferns, Lycopods, Tree-Ferns, Horsetails, Cycads and archaic Conifers, and, finally, the modern Pines, Monocotyledons and Dicotyledons. We now find the Algae confined to water and moist places unfit for any other plants. Lichens and Mosses occur either on bare rocks and vacant places, or on the trunks of trees, and on the ground in woods and other places, where they are occupied in assisting the higher associations of plants. In the latter case, they have been brought under the Forest trees, and become subordinate to the wood flora. Upon rocks and walls, they are still in the sort of country in which their ancestors existed. Precisely the same may be said of the Ferns. The Bracken, Male-Fern, and Lady-Fern are now humble assistants to the forest trees, Pine, Oak, etc. ; but a few, such as the Woodsias, Ceterach, and others, occur at considerable altitudes in the Highlands, though they are not able to bear the conditions which suit Alpine mosses and lichens. The Clubmosses have been somewhat unfortunate. Many of the tropical species are found on trees and branches in the jungles. The few British species are only common on the hills, but may sometimes be found near the sea or at comparatively low levels. Equisetum has been driven to the water, or to very barren ground, where it is able to grow in places that can be colonised by almost no other plant. As soon as it has improved 
the soil it is overflowed and killed out by grasses and Dicotyledonous weeds.

Thus, we see that these former giants of geological vegetation, now form either a series of Celtic fringes on the hills, and upon specially barren ground; or, in many cases, that they have been overflowed by the more highly developed plants, and now cling tenaciously to menial positions which require only a poor sort of structure; but which are none the less of advantage to the Forests or Marshes in which we find them. The Peatmoss stands out as a sort of Chinese type which cumbers the ground, and still defies, not merely the highest organised of vegetables, but even man himself.

The subsequent history of the Pines, Oaks, and Mixed Woods, and of the modern British Flora, will be found in Chapter XV.

It is therefore clear that Ferns, Clubmosses, and Horsetails, though at present they are probably less useful to man than any other kind of vegetation, have had a very important share in the preparation of soil fit for higher and more specialised plants. 


\section{CHAPTER XV.}

THE PINE AND OTHER CONIFERS, ALPINE PLANTS, AND THE HISTORY OF THE BRITISH FLORA.

THE Coniferae, as has been shown in Chapter XIV., are a very ancient group of plants. In most respects their structure is much less specialised than that of the Dicotyledons or Monocotyledons. The foliage especially is of a much lower type. In almost all the Conifers the leaves are either very small, somewhat like those of the Clubmosses or Lepidodendra in external characters, or they are needle-shaped like those of the great genus Pinus. Very few are deciduous, though the Larch, one of our commonest species, sheds its leaves in autumn. The branching is generally very regular and of a monotonous character, markedly different from that of other trees, in which there is a much greater power of adaptation to unforeseen circumstances.

For example, the annual shoot or year's growth of the Scotch Fir (Pinus silvestris) consists of a branch several inches in length, with numerous little branchlets, or rough tubercles, along it. Each of these carries two green needles, and there are generally from one to three buds at the end. If these buds are dissected it is found that they contain the rudiments of the next year's shoot. The bud is wrapped in a series of brown resinous scales which entirely cover it, and within these scales there are a series of miniature buds, each wrapped in a few 
scales belonging to itself, and containing two minute embryo needles. On looking back to the original older branch, it is easy to find the traces of both the separate and the general scales.

The mature needles are hard and stiff. As regards their internal structure there is one large vein in the centre. This consists of two groups of xylem and phloem connected with the sheath, or endodermis, by special transitional cells. The green cells are closely packed together, and fill up the space between this sheath and the layer of cells just below the epidermis. The latter is made up of thick-walled cells which form a supporting or strengthening cylinder, giving to the leaf considerable rigidity. On looking for the stomata, it will be found that they are sunk below the surface of the leaf. This arrangement hinders the ready escape of water, so that there is but little transpiration; and, in fact, a pine gives off only about one-sixth part of the water transpired by an average oak tree, or other Dicotyledon, in the same time. This probably explains why the needles are peculiarly subject to injury from smoke or other impurities. In their natural position, they are exposed to wind and snow, and are more likely to lose too much than too little water by transpiration. It often happens that, whilst the sun is shining, the ground in a pinewood is frozen hard. Under these conditions no water can enter the trees, and yet the stomata will be open and will give off water vapour. The result may be that the whole tree withers and dies from lack of water. Thus there is a necessity for keeping down transpiration, a necessity which the arrangement of the stomata on the leaf seems intended to meet.

The leaves also show several conspicuous resin canals 
which are probably necessary to prevent the attacks of insects. Resin is a very characteristic product of all Pines, and occurs in great quantity in the stem and roots (see p. IO2).

The wood of any Conifer is much more even and homogeneous in character than that of "hard" or deciduous woods; the annual rings are very distinct

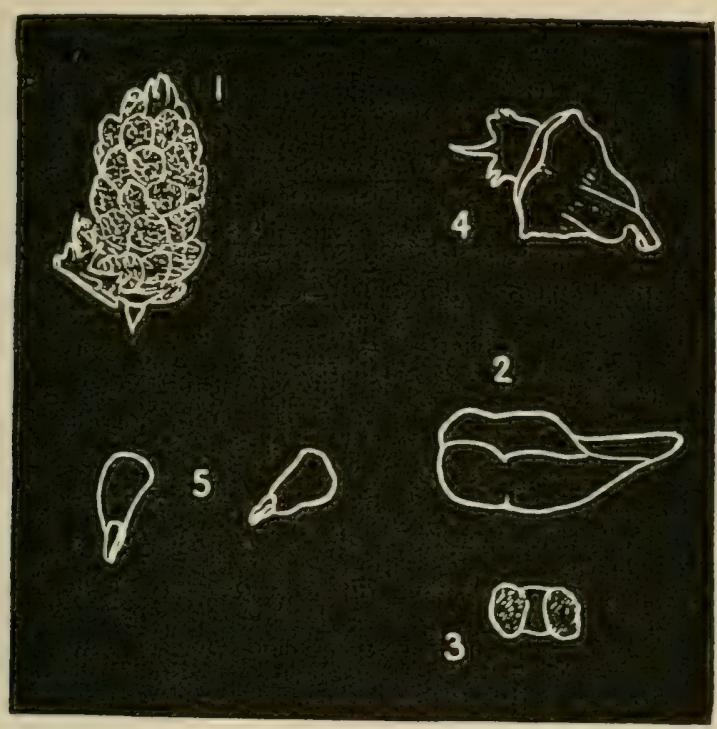

FIG. 36.-FLower of THE PINE. (I) Male flowers of Pinus sylvestris. (2) Stamen of Pine from in front. (3) Pollen grain. (4) Ovule-scale and coveringscale of Douglas Fir to show dutible character. (5) Seeds of Douglas Fir for the wing.

and often of considerable size. There are very few vessels in Pine timber. The wood is made up chiefly of "tracheids," which are very similar in shape to the cambium cells, and are greatly thickened. They have peculiar valves on the walls, which allow the water to pass easily from one to another without interfering with their strengthening function, or efficiency as supporting elements of the stem. There are also very numerous medullary rays which pass inwards amongst these 
tracheids, and thus preserve a living connection with the water current. The cortex cells are therefore well supplied with water. The homogeneous character of coniferous timber makes it very easily worked, and the resin acts as a preservative against bacteria, and other agents of decay; so that this sort of wood is much more used for general purposes than the wood of the deciduous trees.

The flowers of the Pine differ altogether from those of the Dicotyledons. They are either male or female and are generally dependent on wind-pollination. The male flowers occur in little clusters. Each is a spiral of stamens, and corresponds to a short branchlet or needle-bearing tubercle. The stamens are placed in a spiral above each other, and, when in bud, are protected by their tips or ends, which fit closely together. The two pollen sacks are on the under surface. The wind carries off the pollen, which falls on to the back or into the hollowed tip of the stamen below. The pollen grains are well suited for wind transport. Each has the outer coat expanded into two small floats which act like balloons, so that the pollen is very light, and may be carried a great distance. Pollen is produced in great quantity, as is generally the case with wind-pollinated flowers.

The Pine cone is very different from the male flowers. It probably corresponds to a whole year's shoot, and may be a contracted inflorescence, or it may possibly correspond to a single flower. In most cases the cones of the first year are slightly coloured. Those of the Larch are particularly beautiful, and it is by no means certain that they are not visited by insects. Generally, these first year cones are very small (from a quarter to half-an-inch in length), and they are 
easily overlooked. They consist of a quantity of double scales arranged in a spiral. The double scale consists of an upper part which later on usually becomes woody and much expanded, and of a lower membranous part, both of which are especially easily seen in the cone of the Douglas Fir (Pimus nobilis). The exact nature of these two scales is by no means certain. Generally the upper one is supposed to be a female flower, consisting of a flat axis which bears the two ovules, whilst the lower one is its bract. Some writers have suggested that the upper ovule-scale is really the two edges of the lower one, which have been doubled over (see Worsdell).

The two oinles are quite exposed on the upper surface of the scale and near the axis. There is therefore no closed ovary, as in the higher plants. But the ovules are not so liable to injury as one might expect, for they are exposed only for a very short time. The pollen, after being blown to the ovule, is drawn down into the latter by a special mucilage secreted by it. Very soon after this, the cone is closed up by the growth of the scales and by the secretion of resin, so that the entire cone becomes a hard resinous body which is quite impervious. Even the nutcracker, a bird which is exceedingly fond of pineseeds, cannot break open the cone or touch the seeds until the scales open of themselves later on to allow the seeds to escape.

The scales remain sealed together for two years, during which they grow to the mature size, and the seeds gradually develop. Eventually they open, generally in the afternoon, and in windy, dry weather. The seeds, by this time fully ripe, are beautifully fitted to catch the wind. They have a long, thin 
membrane, shaped like the propeller of a steamer; and as the weight is slung obliquely, they twist and revolve so that they take a long time to fall and may be carried to a great distance.

The distribution of the Pines and the other Conifers most nearly allied to them is very interesting and

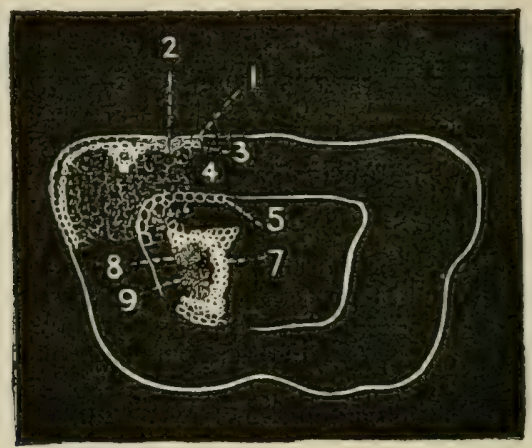

Fig. 37- - LEAF of AkAUCARIA (seen in transverse section). The strengthening or mechanical system consists of the epidermis (r), the layer under the epidermis (3), the endodermis (5), and the white strengthening sheath (7). Water enters the leaf by the xylem (8), and is carried by special valved cells (6) to the green cells (4), which have peculiar shelves on their walls appearing as points in the figure; the water not required escapes by the stoma (2), which is sunk below the surface. Near the stoma is seen a resin canal, protective in function. The phloem by which food-material is carried away is seen at (9).

instructive. A general survey of the world, from the Arctic to the Antarctic, shows that Siberia, Northern Canada, and Northern Scandinavia, are all largely covered by pine woods. There is a Coniferous belt in both the Pyrenees and the Alps, above that of the Oaks and other trees. Even the isolated mountain strips of the Lebanon and Mount Atlas possess the Cedrus Libani and Cedrus Atlantica. The Canaries had their woods of Pinus Canariensis, and the small mountain group of Milanji, away in the extreme centre of Africa near Lake Nyassa, has its forests of Widdringtonia Whytei. Indeed, everywhere on the earth's surface we find particular kinds of Conifers associated 
with particular mountains. Both in America and Asia the same sort of Coniferous belts occur perpetually. The Mammoth trees (Sequoics) and the Araucaria forests of Chili, as well as the Deodars of the Himalayas, occupy ground which has not yet been reached by a Dicotyledon capable of overshadowing them. Even in the extreme southern regions, verging on the Antarctic, the Kauri forests of New Zealand are still an important Coniferous region. In all these cases the Conifers are in the position of a "Celtic fringe." In some few localities they have, like the Swamp Cypress, been driven to the water; so that, in this last case, their history resembles that of the crannog builders, or of the early Venetian refugees. They only survive in their present position, because they are able to maintain existence by such extraordinary adaptations as roots intended for respiration.

It is not difficult to understand why they now occupy such places, if we remember the botanical history of Britain. This latter subject is well described in an invaluable work by Mr. Clement Reid (Origins of the British Flora). It is known that seventy-five of our modern species were in Britain before the commencement of the Great Ice Age. These are of course only a fragmentary Flora, consisting of those which happened to be preserved under specially favourable conditions. They are chiefly water and marsh plants, such as the Bog Bean (Menyanthes), the Water-milfoil (Myriophyllum), the Hornwort (Ceratophyllum ), and the Marsh Violet. The first three have been detected in remains of early glacial, interglacial, late glacial, neolithic, and Roman times. They still exist in apparently exactly the same sort of places that they frequented in those days. 
There is no general agreement amongst geologists as to the character and number of the Ice Ages, which, of course, greatly interferes with a continuous history of the successive invasions. In a broad way it may be supposed that after Pliocene times, which enjoyed a sort of subtropic to temperate climate, there came into existence the intense cold of the first great Ice Age.

Even then there seems to have been a series of welldeveloped Arctic plants. They are now supposed (Engler) to have originated in the Caucasian Mountains, and to have very early in their history migrated northwards, so as to form a circumpolar flora stretching all round the North pole, where they, with their attendant mosses and lichens, still exist.

This ice sheet seems to have advanced southwards over the greater part of Central Europe. During that period of ice and snow, any exposed rocks or plains must have endured the severest climate of the Farthest North. After a long interval, the ice sheet retreated northwards, and a subtropical climate, apparently much warmer than that of our own times, reigned. Again, and probably several times over, the ice sheet advanced southwards, driving before it, or killing out, the subtropical inter-glacial plants, and again meited. Then it finally retreated to the Arctic regions, and the present distribution of animals and plants came into existence. It is often supposed that present conditions are as permanent as they appear to us; but this is a mere assumption. It is better to look upon the flora as being still in migration. The ice cap has reached a certain average Northern latitude. The Arctic plants and those of the tundras form a circumpolar fringe round it. South of the Arctic plants, the land is occupied by forests of Pinus Sylvestris or of other 
Conifers; and to the South of the Pine region, there is the vast extent of country formerly covered by Oak forests. Still further South, on the Mediterranean coastline, we find a flora of Sweet Chestnuts, of Olives and Vines, and a climate which is very much more genial than that of Central Europe. All these great associations, or Floras, may be looked upon as arrested on their journey north after the retreating Ice Sheet, and upon their border lines they are contending with one another for the use of the soil.

In many respects, greater height above the sea acts on plants in the same way as a more Northern latitude. Thus, even on such minor mountains as are met with in the Highlands of Scotland, we find at the very summit arctic-alpine plants ; below these a part of the mountain inhabited by heather and peat moss; lower still, brackencovered pasture, once probably covered by Pine forests ; and in the most sheltered valleys, Oaks and deciduous trees. What actually happened seems to have been somewhat as follows. When the glaciers and their attendant alpine-arctic Mosses and Lichens gradually passed northwards, the Pine forests advanced behind them, and eventually occupied the whole country driving the alpine-arctic forms to the summits of the hills.

The Pines were then invaded, and dispossessed of the more sheltered valleys by Oaks and other plants. The Beech and a whole host of other trees are now found covering parts of the lowlands which were once in all probability occupied by the Oak-forest. Thus the present distribution shows a sort of zonal arrangement which may be well followed on the map in Geikie's Scenery of Scotland.

It will be seen that some six distinct vegetations are here recognised which are as follows: 
I. The Arctic-alpine association, in the broadest sense, which is only found at great altitudes or on the sea coast (see p. I 95). The level varies in different parts of Britain. Thus plants of this character occur at much lower levels near Helensburgh than they do in Dumfriesshire (Oryria digyna occurs at 600 feet on Benchaorach and at nearly 2000 feet near Moffat). Their lower limit is often much higher on the southern side of a mountain than on its northern flanks. Moreover they are often carried down the steep slopes of the burns and colonise shingle beds and sandbanks a long way below their proper position. Hence their correct range is very difficult to determine. Oxyria digyna, Alchemilla alpina, Silene acaulis, and Gnaphalium supinum are good types of this flora.

2. The Pine-bracken flora has been so much altered by the grazing of sheep, and the destruction of the Pine-woods, that it is almost impossible to find any typical examples. Parts of the Black Wood of Rannoch, the older parts of the pine forest near Rothiemurchus and Spey Bridge, and Achnacarry forest are supposed to be as nearly primaeval as we can find in this country. The Sylva Caledonica of the Romans is supposed to have been this Pine forest, and traces of it may be found in many peat bogs below the stratum of bog oak. In Denmark it seems to have covered the country when man was in the Neolithic stage of civilisation.

3 and 4. The Oak-forest association and that of the Beech covered the greater part of the British Islands at the time of the Roman invasion. The country has becn completely cleared of these woods, and the ground has been so much altered by replanting and by cultivation, and possibly also by climatic changes, that it is 
not possible to distinguish between them. The vast majority of British plants, or at least of those that are to be considered as really wild, belong to the Oak or Beech floras.

5. The Mediterranean or Portuguese Invasion. The Cornish Heath and others are found in a few isolated spots along the South and South-west of England, and nowhere else. Most of their habitats are in the little strip of England which enjoys from I600-I 700 hours of sunshine annually. See Bartholomew's Physical Atlas, Plate I 8 (H. N. Dickson).

The arrangement of these successive belts seems to show that, after the removal of the ice sheet, the island was colonised from the South and South-west by successive companies of immigrants. It is possible, however, that the above account is too general, and that many may have entered the country from the East, across what is now the German Ocean.

One small body of American-Irish plants, the Blueeyed Grass (Sisyrinchium) and Eriostemon sexangulare, secms to have travelled across the Atlantic. But though there may be many exceptions, the only broad generalisation possible appears to be, that the main body of our British Pine, Oak, and Beech floras came from the South and South-ivest, and then gradually overspread the islands from South to North.

The above description does not apply to the following groups (7), the Water and Marsh flora (see Chap. IX.), (8) the Seaside flora (pp. I 9 I to I97), and (9) Weeds and Introductions. The last is a large and heterogeneous body, coming from almost every part of the globe, and still in course of immigration. A very short notice of these will be found in the concluding chapter. 
The Arctic alpine flora is entirely confined to the exposed windy summits of the highest hills in the country. The plants rarely exist below 1400 feet in Southern Scotland.

On the other hand, in Scandinavia they occur near sea-level, and the circumpolar Arctic flora is entirely composed of some of these plants, and of closely allied forms. They all possess special adaptations, by means of which they can endure the snow of winter, the very short hot summer (sometimes only six weeks in length), and the incessant storms of wind and rain to which they are subjected, on the bare and desolate mountain peaks which they inhabit.

One characteristic feature comes out very distinctly if we compare closely allied species, of which some are alpine and the others lowland forms. Alchemilla alpina differs from Alchemilla vulgaris chiefly in the leaves. These are of a silvery white colour, due to a dense covering of hairs. Cerastium alpinum again is thickly covered with beautiful white down, whilst the lowland Mouse-ear Chickweed is either glabrous, that is entirely without hairs, or its hairs are of a totally different character. This is a specially good example, for there is a variety of Cerastium triviale, var. alpestre, which is much more hairy than the ordinary form, and this also is found high up in the mountains.

It may be considered proved that these hairs prevent the water from escaping too rapidly from the leaves, or, in other words, that they diminish transpiration. The plant, in fact, develops a coating of hairs to keep in the water. The same Cerastium also illustrates a very well-known characteristic of alpine flowers, which are generally much larger and more conspicuous than those of the lowland species. The flowers of C. alpinum, of 
C. triviale alpestre, and C. triviale are in descending order as regards size. The British flora is, however, very poor in alpines. For example, it gives no idea of the extraordinary variety of colour which is to be found in the Alps or the Pyrenees. Not only are the flowers there relatively larger, but their colour is often strongly intensified. Rich blues, purples and crimsons are very abundant; in fact, so marked is this character that a great many alpine plants are in cultivation, and a rock garden generally contains a very large percentage of them (see p. 2 I).

Both seeds and living plants have been brought from the Alps, and cultivated in the lowlands with the special object of testing the effect of the climate on the flowers. It was found that in the lowlands the colours were decidedly less brilliant, and the flowers relatively smaller than they were in their original alpine habitat.

Besides this tendency to brilliant and large flowers there is a very different character. In Alpine situations grasses and other plants produce degenerate flowers in which the parts have become leafy and green. Sometimes instead of the proper flowers there are fleshy bulbils similar to those of the garlic, and capable of growth and of reproducing the parent plant. A good instance is that of the Polygomum already mentioned, $P$. vivitamum. Ptarmigan are said to be specially fond of these fleshy bodies and probably aid in the distribution of the plant. No complete explanation has ever been given, at least to my knowledge, of this "viviparous" tendency of alpines which was first mentioned by Linnaeus, who, in 1796 , noticed also the dwarf character (exiguae), the harder, more woody and shrubby appearace, as well as the succulence of alpine plants. This dwarfing is perhaps most easily realised by comparing any of the alpine 
willows with the lowland forms. These latter are very often tall and vigorous trees. The characteristic alpine forms are extremely small, and, though woody and perennial, have a straggling or trailing habit. Salix lapponum, S. herbaceum and S. repens are all of this dwarf character, and the latter is very often only two or three inches in height. This suppression of growth probably depends on the exposure and the severe climate. It has already been pointed out that in some respects the seashore and the mountain tops have very similar conditions. Along the sea-side, dwarf specimens of shrubs and trees are very common, and they are probably prevented from developing in the proper way by the high winds, and possibly, also, by the large amounts of salt in the soil.

Bonnier has shown that alpine seedlings, when grown under ordinary lowland conditions, are very different in height, in general habit, and in appearance. This is of course only what one would expect, as the six weeks of an Alpine season cannot possibly produce the same luxuriance of vegetation as six or seven months in the lowlands.

The importance of the work of the Alpine plants lies in their being able to exist on bare mountain rocks. They thus supply the smaller Alpine streamlets with the vegetable matter in the silt of which the small streams often carry an extraordinary quantity. As much as from 6.577 to I 45 .ro7 kilogrammes of silt per cubic metre has been detected in an Alpine torrent.

The coniferous belt and the intermediate stretches of moorland and peatmoss have a similar important function; but they are also sufficiently efficient as vegetation to pasture sheep, or to carry in places valuable forests of Coniferous timber. 


\section{CHAPTER XVI.}

\section{WOODS AND FORESTS.}

IT is only under the most favourable circumstances, and in places which enjoy the very best conditions of light, moisture, and shelter from wind, and only upon the richest soils, prepared beforehand by a long series of former vegetations, that woods and forest are able to develop.

They represent, in fact, a final effort of Nature in the way of natural vegetation. In them, the organic material produced every year is infinitely greater than that formed by any other association of plants. In woods, also, there is extreme division of labour, minute specialisation amongst the constituent plants, and a very much greater organisation than occurs in Mosses, Moors, Grasses, or other natural plant communities. It is therefore necessary to give a short account of WOODS considered as ORGANISMS.

In a previous chapter, the body of a plant was shown to be composed of many cells, each of which has its own work, but is yet entirely subordinate to the welfare of the whole plant. Very much the same may be said of the different plants which constitute a wood. Each has its own special function, and its work benefits the whole wood as well as itself. Moreover, its development seems to be controlled by laws similar to those that govern the individual cells in vegetable tissues. Woods 
have an absorption system and an assimilation system, and have made provision for the breaking up and destruction of useless or inefficient individuals. They grow and die; they have to compete with other sorts of vegetation; and in many other ways they may be compared to a living vegetable.

This method of considering plants in associations has been implicitly followed in some of the preceding chapters. It is based on the work of Eugene Warming and others, who have, in this respect, produced a thorough revolution. Yet the idea is not new; for, though the botanist has never been able to see the wood for the trees, even prehistoric man must have had a very thorough idea of the meaning of such terms as "Wood," "Marsh," "Mloor," and "Loch."

The chief difficulty arises from the specific and individual differences. An attentive observer will find slight differences in every woodland; and, of course, the tropical rain-jungle of the West Coast of Africa is totally different from the New Forest in England. But any ordinary sort of deciduous plantation in Britain, will distinctly show most of the features which are described here, provided that it is of some extent, and is not grazed by cattle, or in a very bad state of decay.

The most important points are: (I) The Foliage surface of the trees; (2) the covering or "Floor" of the wood; (3) the Undergrowth of shrubs and creepers; (4) the Bark-flora, chiefly Mosses and Lichens ; (5) the Subterranean system; (6) the Plants on the edges or borders.

Thus, if one imagines a section through a wood, such as is roughly shown in the diagram, there would be first the dense leaf-surface, or foliage dome, formed by 
the tall or dominant trees. At the edges the trees adapt themselves, as far as possible, to the conditions; but generally shrubs or small trees (often the same as those found in the undergrowth) occupy vacant spaces below the larger branches. This general foliage surface shows very interesting variations, according to exposure and other conditions. Thus, if a narrow and deep

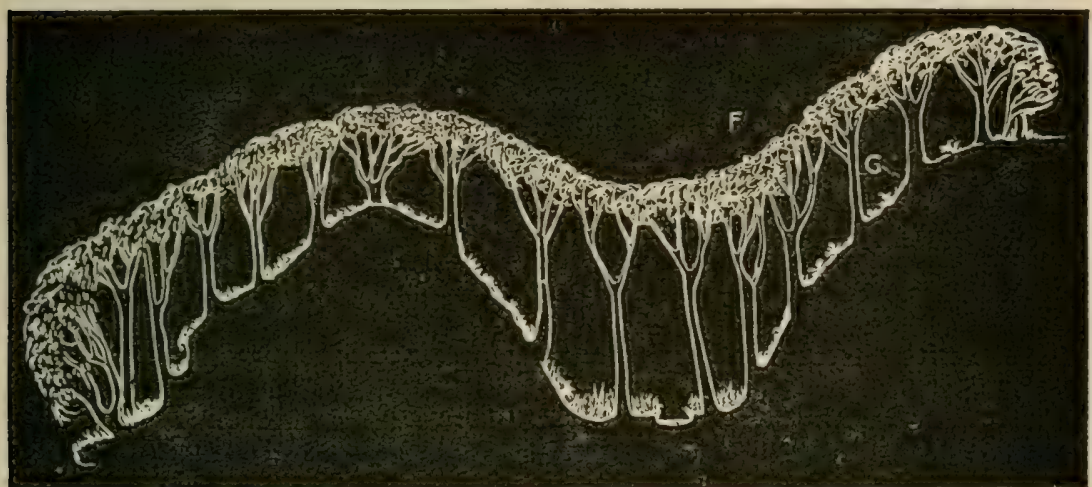

Fig. 38.-Diagram of a Section or Profile of a Wood. The foliage surface $(F)$ is continuous but is not parallel to the contours of the ground. Near the small stream in the valley, the trees and also the herbaceous plants on the ground are much taller than at the summits of the hills. The wood-carpet $(\mathrm{G})$ is shown to be nearly continuous. Note also the convex curves of the foliage surface at each end of the wood.

ravine traverses the wood, the surface often runs across it. The trees near the water are much taller than those on the slopes. Then, again, if a river interrupts the wood, there is a beautiful convex curve, which is familiar to everyone, in the foliage surface.

Any light, which passes through its leaves, is intercepted either by the shrubby undergrowth, by bark lichens and mosses, by Ferns, or by the mosses and small flowering plants on the soil. The Undergrowth in Britain is usually composed of Rosaceae (Raspberries, Brambles, Hawthorns, Sloe, Rowan, or Roses). Honeysuckle and Ivy are the only common creepers, and are 
often artificially introduced. Amongst other typical undergrowth plants are the Guelder Rose, Dogwood, Elder, and Holly, as well as many foreign species which are chosen for ornamental purposes, such as Laburnum, Lilac, Maple, and occasionally Rhododendron. Though very often absent, there are interesting points about this undergrowth, especially as regards what happens at the edges of the word, or after the wood has been blown down.

The Bark-flora is in Britain almost entirely Cryptogamic. In other countries, flowering plants continually establish themselves in the forks of all old branches, or even on horizontal boughs. There are no bark Orchids, Aroids, or Figs, in British woods. Even the Mistletoe is very rare. The only representative of these "Epiphytes" is an occasional Gooseberry Bush, which may be discovered perched on an old tree, and developing quite satisfactorily.

On the other hand, there is an interesting series of Lichens and Mosses. Those found on the youngest twigs are generally lichens, especially Lecanora Subfusca, or some species allied to it. On rather older branches various olive brown Physias or grey Pamelias make their appearance. Evernia prunastri and $E$. furfuracea are also very common on the older trees. If these latter are well grown, the bark of the trunk may be nearly covered by a profusion of grey lichens, such as the dark leaden-grey, white-dotted patches of Pertusaria, the leaf-like fronds belonging to Parmelia physodes, and, on very old trees, the greenish-grey Usneas and the drooping olive-grey tangles of Alectoria flexuosa (see p. 244).

These lichens follow one another in a regular order, and it is easy to trace the sequence by observing how, 
for instance, a Parmelia will overgrow a Lecanora, and occupy its place. They occur generally on the drier and more exposed part of the twigs and branches. On the sheltered side, there is often a continuous green cushion of moss. The Mosses show a similar succession, and appear to grow best along the course which is followed by the rain-water when trickling down the stem. In very wet places the Alga, Pleurococcus, forms a continuous green coating, which often wholly covers the wettest side of the tree, though absent on that which is exposed. Round the base of the trunk there are very often colonies of the grey Trumpet-lichens (Cladonia) or a dense moss-carpet. Even ferns may be sometimes seen on its branches in especially favourable spots. Thus the bark flora is a very considerable one, and is by no means without importance (see p. 309).

The Male-fern, the Bracken (in pine woods), the Oak and Beech ferns, and others, are the most characteristic Wood-floor plants in Britain (see pp. 271, 287). Of the flowers, Dog's Mercury, Stachys silvatica, Garlic, Hyacinth, Foxglove, Campion, Luzula, Woodruff and Enchanter's Nightshade are amongst the most abundant. They are especially suited to the loose, light, leaf-mould, in which their rhizomes can grow without difficulty, and they appear in orderly succession one after another all through the season (see pp. I 7, 65). There are also special wood grasses, such as Bromus asper, Brachypodium and Melica. But very often the surface, especially in winter and spring, is matted over by a profusion of mosses such as the feathery Hypnams and Hylocomiums, or it is covered by tufts of Bryum or Polytrichum. The covering shows in fact an extraordinary variety of vegetation; it varies from month to month, so that many different plants are able to produce 
their foliage on the same place; and it varies also according to the dominant tree (Beech, Oak, or Pine), and according to the amount of moisture. A study of the same piece of woodland at different periods of the years is, for this reason, full of interest.

The assimilation-system of the wood is made up of all these different floras. Any light which passes the leaf-screen is sure to be intercepted by the undergrowth, by lichens or mosses on the bark or by the ferns and other plants on the floor. Thus the year's formation of organic matter depends, not only upon the leaves of the taller trees, but upon these other floras in addition. Sooner or later pieces of old bark and twigs drop off and the lichens and other Cryptogams are broken away and join the mass of dead leaves, decaying mosses and fern-fronds, petioles, etc., which covers the surface of the ground. Along with these vegetable fragments, the remains of insects and animals of all sorts, which have found refuge in the wood, eventually reach the earth.

All this organic matter is gradually made available for further employment by the absorption system of the wood. Therefore, it must be remembered that even the lichens and mosses, and the minutest beetles that seek refuge amongst them, assist in the nutrition of the general plant community.

The absorption system of the woods is exceedingly complex. The dead leaves which fall in autumn are very gradually disintegrated. The cork coat of the twigs and branches requires a specially long period to decay into plant food. It is only possible to mention the most conspicuous stages, for very little seems to have been published on this subject. Fallen leaves appear to be first attacked either by insects, or by other animals. These break their way through the cuticle 
and epidermis, and soon destroy the softer parts between the nerves; or, if the weather is wet, and favourable to their development, Fungi begin to break up the inner tissues, and only leave a sort of framework of nerves and the more rigid parts. By the following spring the Mosses run over the last year's leaf-fall ; and, by their quickly formed and very efficient rhizoid or root-hair system, further disorganise them. Next September the remains of the leaves form part of the food material of the Ground-fungi (see below). In subsequent seasons they will still yield food to these fungi; but as they become covered by new leaf-falls they will be also explored by the root-hairs and fungus-servants (Mycorhisa) of the Ferns, Garlic, Hyacinths, and other plants. Eventually, every part of any value is turned to account and enters the Mycorhiza of the trees, and is utilised for the formation of new leaves and woody material. During the whole of this gradual process of decay, countless animals are at work. They burrow about amongst the rotting material, and ensure a free supply of oxygen, which is essential for the development of the roots, and even for that of the ordinary fungi.

At every stage, also, bacteria come into action. The dead fungi as well as dead animals and their droppings are broken up by them. The ammonium-compounds thus produced are, probably, converted by other bacteria into nitrates. Some forms of fungi are even able to utilise ammonium compounds directly. The history of the sulphates and phosphates is still obscure; but it is most probable that bacteria or fungi are also essential for their formation.

The destruction of dead logs and branches is a very lengthy process, and varies so much that it is difficult 
to give even a general description of it. Any unhealthy or wounded tree is quickly attacked by Polypori, such as $P$. squamosus, $P$. betulinus, Agarici of the group Pleurotus, and especially by $A$. melleus, and by Stereum hirsutum and S. purpureum. These fungi always attack the cambium and phloem first. They loosen and destroy the tissues between the bark and the wood. In the space thus formed, the Bark-beetles, Centipedes, Woodlice, and other creatures establish themselves. Their eggs are laid in the most sheltered positions, and their grubs cause further destruction. Sometimes, however, the bark-beetles precede the fungi and attack the softer tissues of scarcely injured trees.

The medullary rays, which it will be remembered extend inwards into the wood, and consist of thinwalled cells with plenty of food material, are also attacked, both by the fungi, and by these insects. After these preliminary processes, two groups of fungi become of special importance. The little cups of Ascomycetes (see p. 238) are found on the dead wood below the loose bark. In the same position, many of the Slime fungi or Myxomycetes occur. During their active condition, and even in the stage in which they form crawling slimy "plasmodia," they explore the medullary rays; and the whole woody mass, and the timber on which they have been at work, soon crumbles into dust (see p. 236). As soon as the cork is broken through, the disappearance of the $\log$ is relatively very rapid. The destruction of the cork is generally the result of several years' decay. Probably mosses, lichens, and especially fungi, are the most important agents in this destruction. Certain kinds of fungi, such as Nectria Cimabarina and others, habitually break through the cork to form their fructifications. Beetles 
aiso burrow through it, and contribute to its decay; but it is in its tenacity, and in its resistance to the agents of destruction, that it is most remarkable.

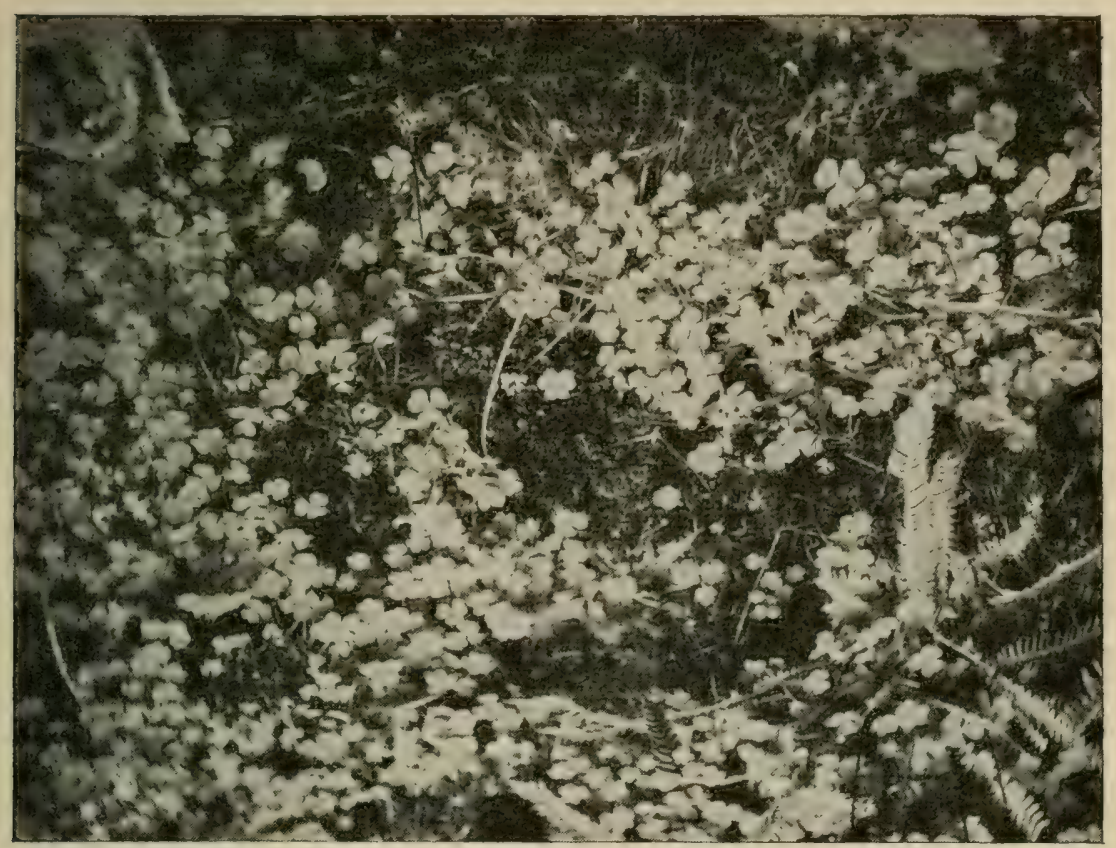

FIG. 39.-The Woon-Carpet or WoOd-Floor. The ground though under trees is wholly covered by wood-sorrel leaves, mosses, ferns, and occasional grasses. Photographed from above.

An interesting case of a special felling fungus can be noticed in almost any wood, where the withered and naked stalks of Campion, Hyacinth, and Woundwort, remain erect after the decay of their leaves. These peduncles often remain standing for a considerable time, so as to ensure a gradual scattering of the fruits, or seeds. The felling of these dry stalks is performed by a special fungus, whose little black fruits, like minute glossy-black pin-heads, may be found at the base, surrounded by a discoloured and decayed area which their mycelium has destroyed. These are chiefly 
Sphaeriaceae and of these Heterosphaeria patella seems the commonest in Scotland.

Most of these complicated processes are carried on out of sight, and it is only by carefully examining dead logs and old stumps, that the evidences of these activities can be observed. The number of Agarici seen in Autumn, gives some idea of the importance of these Fungi. The production of a single Agaricus involves a very extensive system of branching, mycelial threads within the soil, and their abundance shows that the humus and decaying matter must be woven together, and pierced in every direction by mycelia. Thus the absorption system of the wood is a very complex one, in which Fungi, Bacteria, and insects of many kinds, as well as worms and other animals, are the most important factors.

If the trees are blown down by a storm, or if the wood is cut down, the process of regeneration takes many years, and is generally marked by a series, or succession, of intermediate plants. This series is roughly speaking as follows: (I) Herbaceous plants; (2) Bramble or Raspberry Brakes; (3) Hawthorn, Rowan, and Birch ; (4) Forest trees. After the trees have fallen, the numerous seedlings of woodland flowers find the conditions extraordinarily favourable to themselves. Campions, Bluebells, Woodruff, Stachys, and others spring up by hundreds and thousands, and produce a brilliancy of colour exceedingly unusual in a sombre country like Great Britain. These herbaceous forms may flourish for two or three seasons; and, if they do so, taller forms such as Foxglove, Angelica, and others appear in profusion. Besides these specially woodland plants, Thistles and Nettles will grow in abundance, if there is a large supply of their seeds available. After this herbaceous 
series, the Rosaceous shrubs begin to occupy the ground in the order given above. They are able to grow over and kill out most of the flowering plants which are soon reduced to their normal proportions. The Hawthorn and Roses soon begin to branch, and grow outwards above the level of the Brambles and Rasps. Amongst them Birches and other trees may be noticed, which, in course of time, grow up and form a new forest, in which all these shrubs are to be found in a subordinate position. It is scarcely possible to find in Britain opportunities for studying the later stages; as the forest is either artificially planted up almost immediately, or it is promptly turned into fields, or into agricultural land.

At the edges or border of the woods, a botanist is sure to find a much more varied flora than in the centre. This is not surprising, because it is on the border that all these transitional forms occur. Once the general idea of the succession has been understood, it is very easy to trace the Campion stage, the Foxglove stage, and the Brambles, Roses, Hawthorns, and Birches along the outside of every well-grown plantation. Of course when it is fenced by walls, there are few to be discovered as the three first mentioned are all generally under four feet in height and are unable to develop.

But the same series is also specially employed by woods to re-occupy land once covered by forests. Most of our arable and pastureland was originally oak, beech, or pine forests; and, if protected from grazing animals, and untended, it would revert to the original flora.

Thus, neglected corners of fields on good and fairly dry soil will soon show a profusion of tall herbaceous plants, such as Heracleum spondylium, Centaurea nigra, 
Thistles, and Sencio jacobaea. If allowed to flourish unchecked, Brambles and Raspberries soon form a sort of thicket; and eventually Hawthorns, Roses, and Birch, or Ash may begin to try and form a wood. The flora to be observed by hedges and roadsides is well worth study in this connection, and shows the same tendency though it varies with the exposure or soil, and is unfortunately continually disturbed by the roadman.

In some parts of the country, generally at a higher elevation and in more windy places, thickets of Sloe and Rowan replace Bramble and Hawthorn. On the chalk Downs and in less favoured situations, Leguminosae may replace the Rosaceae as in the case of the Whin or Gorse thickets of England, and of the patches of Broom in the Scottish Lowlands. These may be the final effort of nature in places which are incapable of bearing forest until the Broom and Whin have thoroughly enriched the soil ; but they may be equivalent to the Bramble and Raspberry bushes, which occur wherever good land is allowed to revert to its original state.

If such a woodland marches with different sorts of vegetation, then the intermediate or bordering plants are appropriate to the special conditions. Thus, in Nithsdale, where woods often cover the whole course of a tributary stream, they will be bordered along the riverside by Alders, and occasionally Saughs or Willows; where it passes through good arable land, Roses, Brambles, and Hawthorn will occur. At a higher altitude, Bracken may cover the hill pasture, where also the Rowan is common. If the wood happens to be near a peat-moss, Sweet Gale, various Salices (not those of the riverside), and Birch may be found; and, finally, at a higher altitude, where the wood tails out, so 
to speak, along a mountain burn, there are often thickets of Rowan, Sloe, and small Birch trees.

Thus there is an appropriate fringe to every neighbouring association, and both the undergrowth and wood-floor plants show, in these cases, appropriate changes.

Woods often become diseased, and they may be destroyed by bad management, or by physical changes in the soil. There is always, for instance, the danger of the soil reverting to a peat-moss. If it is badly drained and becomes saturated with water, worms and other animals are unable to live. The air is not able to pass down the worm burrows to the lower levels, where the fungi are working on the humus. Oxygen is therefore not able to reach a particle of say "cellulose," or cellwall substance, which is on the point of breaking up. It follows that it cannot be destroyed, and must remain only partly decomposed; for the substances into which it would be broken up contain more oxygen than exists in the cellulose. In such a wood, the soil will become a sort of peat, and the special ground fungi will not develop. After a time even the trees will begin to grow badly, and eventually die away.

The special climatic conditions within a wood are very remarkable. The light is greatly diminished; the intensity of the light in an oak wood is to that of daylight as I to 22 ; in a beech wood it is as I to 85 ; and even in an ash or birch plantation it is as I to 5 or $\mathrm{I}$ to 9 respectively. The soil is colder in woods then it is in the open field. The difference is as much as $3.2 \mathrm{I}$ per cent. in summer but only 0.02 per cent. in winter. The air temperature is also slightly below that of the open country. The daily changes in temperature are also much less pronounced. The evaporation 


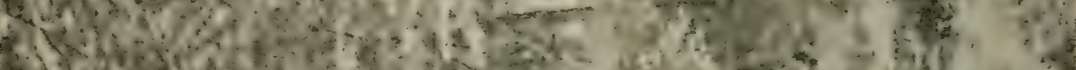

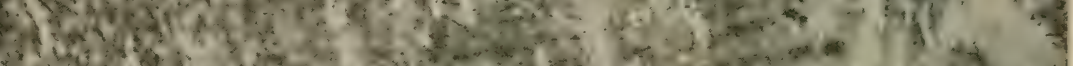

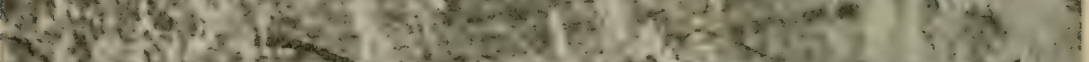

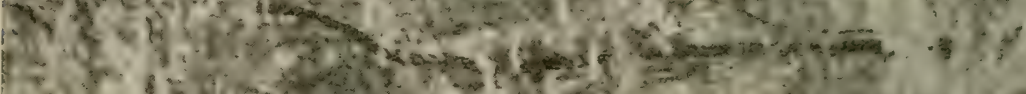

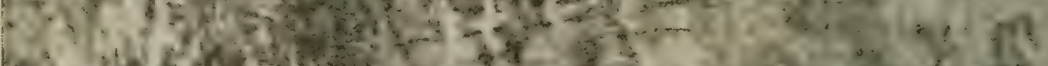

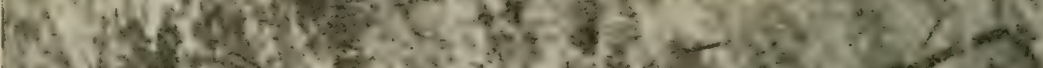

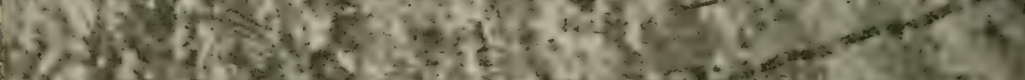

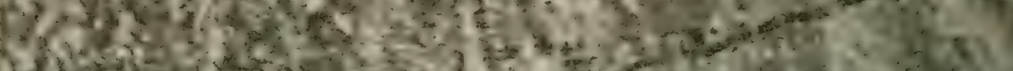

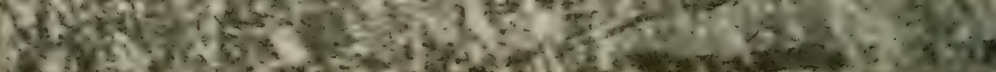

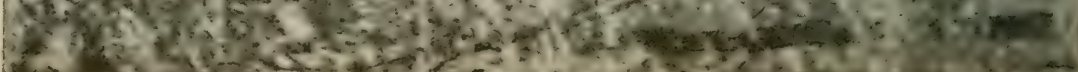


of water is greatly retarded. In a wood with leaf mould less than one-sixth of the water is evaporated, which would in the same space of time be lost on ordinary soil.

All water absorbed, of course, eventually passes out by the leaves, but it does so gradually. Thus, within the forest, there is a moist atmosphere, and of course also a shelter from wind, conditions which are excessively farourable to vegetation. Small streams and rivulets are much retarded in their work of erosion, the roots of the trees and other plants binding the soil together, and preventing it from being washed away, whereas bare soil is rapidly carried off by running water. Thus, by hindering the erosion of the land by the streams, and by delaying the evaporation of water, forests are of great importance to the climate of a country and to its agriculture. Whether the actual rainfall in a region can be increased by forests has not yet been certainly determined.

The annual formation of organic matter in a wood is very great. An average well-grown tree will produce perhaps 700,000 leaves in a year. In the Scotch Lowlands the following table constructed from the observation of Messrs. Renwick and Mackay shows the average increase in girth per annum of the trees quoted:

\begin{tabular}{|c|c|c|c|c|c|c|}
\hline $\begin{array}{l}\text { Maple, - } \\
\text { Horsechestnut, }\end{array}$ & $\begin{array}{l}\text { - Accr pseudoplatanus } \\
\text { - Aescullus hippocastar }\end{array}$ & & & fron & $\begin{array}{c}.44 \text { to } \\
-\end{array}$ & $\begin{array}{l}.78 \mathrm{in} \\
.8 \mathrm{I} \text { in }\end{array}$ \\
\hline Gean, - & - Prunus avium, - & - & & & - & $.85 \mathrm{in}$ \\
\hline Rowan, & Pyries aucuparia, & - & & - & - & $\mathrm{I} .28 \mathrm{i}$ \\
\hline Hawthorn, & Crataegus oxyacanth & & & - & - & $.50 \mathrm{i}$ \\
\hline Ash, - - - & Fraxinues excelsior, & - & & - & - & $.40 \mathrm{in}$ \\
\hline Scotch Elm, & Ulmus montana, & - & & from & .33 to & $.47 \mathrm{in}$ \\
\hline English Elm, & Ulmues surculosa, & - & & " & .50 to & .71 \\
\hline Walnut, - & Juglans regia, - & - & & , & .3I to & .40 \\
\hline Birch, & Betula verrucosa, & - & - & - & - & $.4 \mathrm{I}$ \\
\hline
\end{tabular}




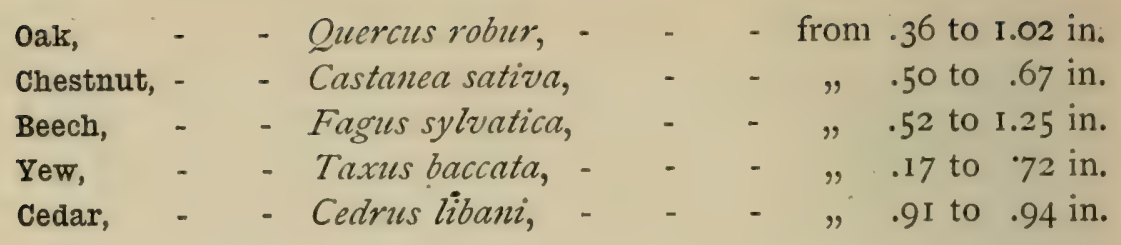

The table shows great variation but gives a fair idea of the increase through a year's work.

Timber may be regarded as a necessity of civilisation, and such data are therefore of great importance. At present the world's stock of timber is becoming seriously diminished. The Siberian, Canadian, and British Columbian forests are still able to furnish large quantities of Coniferous wood, but the following table (Dr. Schlich) shows how dependent most European countries are upon imported wood:

\begin{tabular}{|c|c|c|c|c|c|}
\hline \multicolumn{2}{|l|}{ - } & $\begin{array}{l}\text { Exports } \\
€ \text { value. }\end{array}$ & $\begin{array}{l}\text { Imports } \\
£ \text { value. }\end{array}$ & $\begin{array}{l}\text { Forest area } \\
\text { acres. }\end{array}$ & $\begin{array}{c}\text { Forest } \\
\text { per head } \\
\text { population }\end{array}$ \\
\hline \multicolumn{2}{|c|}{ United Kingdom, } & - & $22,190,000$ & 3,030;000 & . I \\
\hline Germany, & - & - & I $4,820,000$ & $34,490,000$ & .7 \\
\hline France, - & - & - & $3,950,000$ & $23,530,000$ & .6 \\
\hline Belgium, & - & - & $4,100,000$ & I,250,000 &.$I$ \\
\hline Denmark, & - & - & $1,250,000$ & 600,000 & .2 \\
\hline Italy, & - & - & $1,250,000$ & IO, I IO,OOO & .3 \\
\hline Spain, - & - & - & $\mathrm{I}, \mathrm{I} 8 \mathrm{80}, 000$ & $20,960,000$ & 1.3 \\
\hline Holland, & - & - & 726,000 & 570,000 &.$I$ \\
\hline Switzerland, & - & - & 590,000 & $2,100,000$ & .7 \\
\hline Portugal, & - & - & 200,000 & 770,000 &. $\mathrm{I}$ \\
\hline Bulgaria, & - & - & 50,000 & $10,650,000$ & 3.2 \\
\hline Greece, - & - & - & 35,000 & $2,030,000$ & .9 \\
\hline Servia, - & - & - & I 5,000 & $2,390,000$ & 1.0 \\
\hline Roumania, & - & 180,000 & - & $5,030,000$ & 1.0 \\
\hline Norway, - & - & $\mathrm{I}, 040,000$ & - & $17,000,000$ & 8.4 \\
\hline Austria-Hung & fary, & - & - & $53,200,000$ & - \\
\hline Bosnia, Herz & govina, & $3,670,000$ & - & - & -- \\
\hline Sweden, - & - $\quad$ & $4,460,000$ & - & $48,000,000$ & 8.9 \\
\hline Russia and $\mathrm{F}$ & inland, & $5,900,000$ & - & $516,000,000$ & 5.9 \\
\hline
\end{tabular}

The value of the wood imported into Great Britain 
is immense, as is clearly shown by the above table. There is no doubt (Hutchins) that, with skilled management, almost the whole of our requirements might be met by home-grown timber. Even now, Dr. Schlich has estimated that land which pays only seven and sixpence per acre for sheep and grouse would yield a better return under forest ; but, unfortunately, pheasants and grouse are still thought of more importance than the opinion of forestry experts. 


\section{CHAPTER XVII.}

THE INFLUENCE OF MAN.

IN such a country as Great Britain it is almost impossible to discover any wholly natural vegetation. Man has been long in possession of the soil, and has practised many different methods of husbandry, whilst the character of the few forests left has been entirely altered, partly by the demands for timber and firewood, and partly by the grazing of cattle. Even as early as the times of Canute game forests, which must be considered of an artificial nature, were formed (Brown). It follows that man's influence is a very important branch of out-door Nature-study, though it has been strangely neglected by most naturalists.

The tropical forest is probably the most productive part of the world's surface as regards the amount of organic matter actually manufactured annually. Whereas, in our own woods, it is not possible to count more than three, or at the most four layers of foliage, in the wet jungles of the Tropics there are almost invariably four stories. These are:- $(a)$ the trees themselves; (b) the foliage masses of various creepers or lianas; $(c)$ an undergrowth of small trees; and $(d)$ the plants on the ground. In many places, the forest is almost like a continuous Privet or Hawthorn hedge grown to $\mathrm{I} 00$ feet or more in height. There are no glades or vistas but a crowded mass of vegetation from 
the top of the trees to the ground. One may perhaps assume, with Darwin, that the original ape-like animal from which man may have descended came from a forest of this kind. Here alone could he find abundance of wild fruit, and obtain, by climbing, protection from most of his enemies. Even in this condition therefore he had an influence on vegetation.

Palaeolithic man certainly influenced the vegetation around him. He appears to have already discovered fire, the most potent weapon of primitive man. With the aid of fire, it was possible for him to keep off wild beasts, to harden wood for weapons, to make dug-out canoes, and to fell trees. It is not possible to discover how far such people as the inhabitants of the Cromagnon shelter, or those of the Trou du Mouton, utilised fire. It is, however, probable that even then the forests had been, to a certain extent, cleared away. The enormous herds of wild horses on which palaeolithic man lived could only obtain food in a sort of park-like country, or very open wood, interrupted by stretches of grass, like, for instance, the New Forest. In America prairie fires limit the extension of the timber belts by the rivers; and, in such scantily peopled countries as the Albert Edward Nyanza district, fire has almost destroyed the trees, which may have once covered the country.

Although, as here suggested, man may have used this powerful weapon for his own purposes, he seems to have been, in every other respect, wholly dependent on nature. He seems to have lived chiefly upon wild animals, insects, fruits, and bulbs. At this period he occupied the temperate forest region of Britain, Belgium, and Middle Europe. He was housed in holes and crannies of the rocks, probably roughly covered in 
with branches and fern. Although decidedly intelligent, there is no proof that he had any sort of knowledge of agriculture.

When we next find a sufficient basis to form a fair idea of human life, as in the polished stone period, represented by the Swiss lake villages, the difference in habit is very great. The cultivation of wheat, barley, and flax was then understood. The people made thread and linen cloth, as well as fishing nets. The making of these things involved considerable plantations; and it is interesting to note that weeds existed in these prehistoric fields. Some of these weeds came from Egypt, and show that even then the flora was being altered by new introductions, just as it is to-day.

The wild Oat seems not to have been cultivated until the Bronze period, which may perhaps show that the original home of the Neolithic man was somewhere south of the range of this plant, that is, further south than Austria and Siberia. Neolithic man lived on such common wild fruits as Crabs, Sloes, Raspberries, Brambles, and Hazel-nuts; and, besides the plants mentioned, was acquainted with the Plum (Prumus domesticus), a native of the Black Sea and of the country to the eastwards, and the Pear (Pymus communis), a native of Southern Europe and of Western Asia. The dog, cow, pig, sheep, and goat, were all then domesticated.

Where the first grain was sown is, of course, purely a matter of guesswork. Two very different authorities, Lord Beaconsfield and Herbert Spencer, agree in fixing on the desert as the first home of real human beings. Certainly the Euphrates Valley has a strong claim to be regarded as the home of most of the earliest cultivated plants and domestic animals as any place on the surface of the earth. 
Thus it may be gathered that the River-drift man may have influenced the British Flora, and that the Neolithic peoples certainly must have done so, as they seem to have cultivated corn and grazed cattle, and especially goats, in the forests.

The general succession of the Flora has been already traced in a previous chapter. It is assumed that, at the time of the Neolithic settler's arrival, the country was roughly occupied as follows :

Beech and Oak covered the majority of the best lowlands in England. The flat alluvial meadows by the rivers were for the most part a fenland, with dense swamps of Phragmites and other Reeds. Northern England, Scotland south of the Grampians, and the best Highland valleys and seashores supported Oak forests, probably of very fair growth and size. Wherever the land was not of the richest quality, or where it was at too great an altitude to support Oak scrub, there were forests of Pinus silvestris, or thickets of Rosaceous or Leguminous shrubs.

Peat-mosses were found, as they are to-day, at all altitudes, and interrupted the other vegetations. Between the Pine forests and the Alpine plants great stretches of heather extended, much wilder and taller than anything now to be found. In the extreme South of England, within the scanty patches of country from Cornwall to the Isle of Wight, which obtains over I 600 hours of sunshine annually, there were probably pickets of the Mediterranean fiora, of which remnants still hold their ground.

The altitudes limiting the Beech, Oak, and Pine forests cannot be given definitely. Mr. Smith gives (I 900) the present range of the Pine I 800 feet, Oak 1000 feet, and Beech 900 feet for North Perthshire. 
The author would suggest for Dumfriesshire, and the year I 893, I 500 feet as the upper limit of the Pine, 800 feet for the Oak, and possibly 200 to 300 feet for Beech and its allies.

Of this original flora it is difficult to form any idea. The heather moors have been altogether changed by annual burning, and by black-faced sheep. Even the Alpine flora has been altered by the ravages of pseudobotanists and experimentalists, who have attempted to introduce plants. With the first settlement of man, accompanied by cattle and goats, would begin the destruction of the forests. Patches may have been burnt down; but in any case, the continual grazing of cattle and cutting of firewood would change the oakforest into a sort of scrub or woodland, such as may occasionally be found in various parts of the country, in places where cattle are allowed to enter woods. The trees in such scrublands are badly developed, small, twisted, and gnarled. Between them grass begins to grow, whilst the ferns and other forest undergrowths are greatly mutilated. This would become the general appearance of the country in the immediate vicinity of the first human settlements. These were probably chiefly along the coast and on navigable rivers and lakes. As time went on the demand for firewood, the increase of the live stock, and the need for additional grazing lands, which led to the destruction of the woods by fire, extended from these centres of settlement over a large proportion of the country. The condition of the Britons at the time of Caesar's invasion clearly shows that the country was partly cleared of trees, and partly covered with dense and inaccessible forests, in which the inhabitants took refuge when pressed by invaders. That the country was fairly open and free 


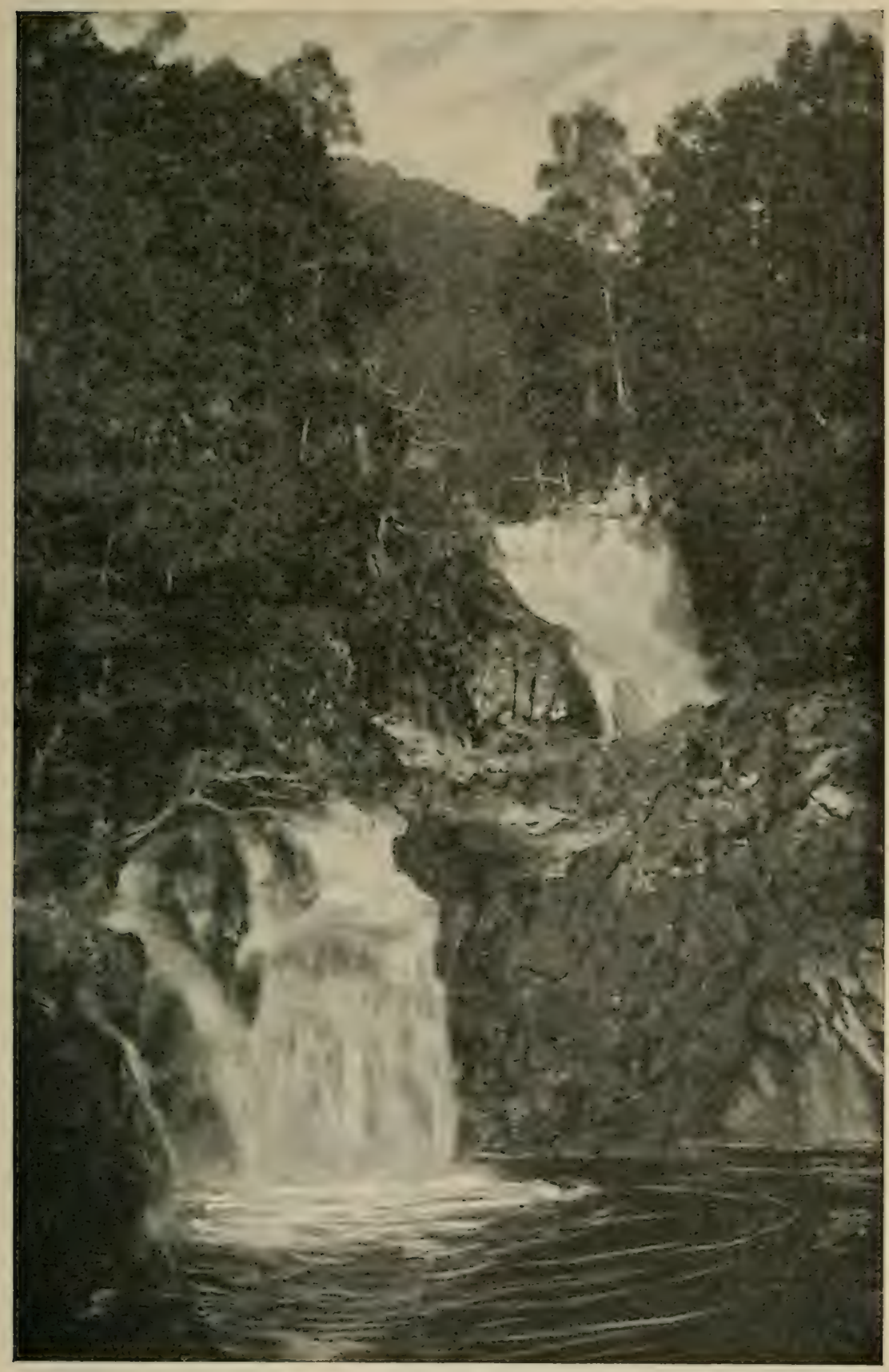

FIg. 4r. -ThE KAIG Falls. Natural scenery scarcely influenced by man. 
of trees in places is obvious from the use of chariots, which in themselves imply a considerable advance in civilisation.

From the landing of the Romans until the commencement of scientific observation and proper records about I750, there are very few distinct and definite accounts of the alteration of the flora.

A network of roads overspread the country; and towns and villages sprang into existence at cross-roads, at the heads of river navigation, at most river fords, and especially at places which were capable of easy defence against all enemies, such as Dumbarton Rock and Edinburgh Castle. Even in the time of Canute it was necessary to regulate the grazing of cattle, and artificially enclosed deer-forests were formed. Later on, in almost every century, there is a continual outcry against the destruction of the timber. The national importance of Oak, Ash, and Yew for shipbuilding, and for the manufacture of spears and bows, can be distinctly traced in various legal regulations, and sometimes also in the condition of the modern country side. Certainly many districts seem to have been almost cleared of timber, and replanting had to be attempted. The eight or nine Ash-trees round so many old farms, and the Yew-trees in the churchyard, represent this period of denudation, when it was recognised as essential that a supply of wood for bows and spears should be always at hand. In some districts trees of any size have been almost invariably pollarded. The branches must have been regularly cut down, and employed probably for firewood, or for foddering cattle.

Cultivation seems to have been very primitive until within the last 200 years. The old statistical accounts of Scotland, drawn up by parish ministers during the 
last years of the eighteenth century, reveal an astonishingly backward condition in many parishes. The Earl of Dundonald, writing in 1795 , and referring either to his own times or to those of I 745, gives the following description :

"The outfield land never receives any manure. After taking from it two or three crops of grain, it is left in the state it was in at reaping the last crop, without sowing thereon grass seeds for the production of any sort of herbage. During the first two or three years a sufficiency of grass to maintain a couple of rabbits per acre is scarcely produced. In the course of some years it acquires a sward, and after having been depastured for some years more it is again submitted to the same barbarous system of husbandry."

In 1745 in the parish of Meigle, there was no ground fallowed; neither peas, grass, turnips, nor potatoes were raised. No cattle were fattened, and only a little grain was exported. A few more examples will show more clearly the state of Scotland about this period, at least in some of the more out-of-the-way parishes. There was one cart in the entire parish of Keithhall, and goods were carried almost entirely on horses' backs. Again, in Fortingal, there were neither roads nor bridges in 1754 , and the country was almost impassable. Most of the tenants lived in small "stake and rise," i.e. "wattle and daub" houses, in which it was not possible to stand upright. They had no beds, but lay on couches of heather and fern.

These quotations leave the impression of a country almost wild, and certainly more like, in its general vegetation, the Britain seen by Caesar than that in which we live. Nevertheless, it is necessary to remember that the incessant demand for firewood and the 
perpetual destruction of young trees by cattle and goats must, even then, have greatly denuded the country. That this was the case seems certain frum the condition of things revealed in the new statistical account, drawn up about the years i 840 to i 850 . After the IVaterloo campaign an extraordinary development of agriculture began; and it continued until the beginning of the recent fall of prices, and the decay of the farming industry.

In the years 1840 to 1850 we find the land still largely open, but being actively enclosed and partitioned off by dykes and hedges. The works of all landscape painters of this period show clearly that, in their time, the ordinary road was entirely without hedges or walls of any sort. Somewhat before this also, about I 8 I 5 to I 830 , the lairds and country gentlemen were, on the whole, extremely prosperous. Many of the country houses were built on a scale of magnificence most unusual before that period ${ }^{1}$; and landscape gardening with its most valuable result, the addition of scattered woodlands and pleasant avenues of trees, became a fashionable pursuit.

Modern farming and industries, with railways, the opening of factories and the general use of coal, have unquestionably altered the vegetation far more than the changes which occurred during all the preceding centuries up to 1820 . The net result is that, in any average landscape in Britain, no part is in an absolutely natural condition. (I) The River alluvium and estuaries are drained and under cultivation; (2) Arable land with special weeds has been formed from original oak-scrub

${ }^{1}$ The $1750-1813$ house compared with the mansion built in $1830-1860$ gives a most instructive comparison of agricultural values at these two periods. 
or rushy, marshy ground; (3) Permanent pasture and sheep farms have been produced from oak-forests or pinewoods; (4) Modern plantations and policies have been formed; (5) Railway tracks, ballast heaps, and shale heaps have appeared with their own special floras; (6) There are special plants by houses or waysides; (7) Trees and other vegetation have been injured by factory smoke; ( 8 ) Rivers have been polluted and so affected the vegetation on their banks.

Beyond the extremely fertile character of the alluvial meadows and their liability to flood in winter, there is little that can be given here to distinguish them from the ordinary Grass and Ploughlands of the general surface. Both these latter are artificial floras. Selected species of grasses have been long employed, and weeds, so far as possible, have been eradicated. Grass land shows the following characters. Generally the vegetation is excessively close and thick, so that the colour of the soil cannot be seen. It is green all the year round, for though old leaves and haulms die away, a young growth is always ready below. The fibrous roots are excessively numerous and form a thick turf. Most of the plants are perennial, and only a very few form any reserve store of food material ; bulbs and fleshy rhizomes are unusual. The wild oat, however (Arrhenathmun), has peculiar little fleshy tubercles or "corms," and Poa bulbosa has also a sort of corm; but this plant prefers a sandy soil. The grass pastures are often remarkable for the absence of weeds. The leaves of those that do occur, are generally either more or less grass-like, or are finely divided, so that their lobes or divisions are flexible and narrow enough to compete with the grasses. Thus Plantago lanceolata, Achillea ptamica, Scabiosa, and the 0x-eye daisy have rather narrow leaves 
resembling, so far as outline goes, that of the grasses; whilst Yarrow, Buttercups, and Umbelliferae have finely divided leaf segments which are able to compete for sunlight with the numerous grass blades. Such grasslands are always difficult to keep in the same condition. If at all neglected, they tend to throw back to the original vegetation of the region which has generally been either marsh plants, such as rushes, or forest. Each plant in a grass field has a specially favourite situation as regards water. Thus, Poa pratensis is said to prefer a rather dry soil with subsoil water 6 to 9 feet below the surface, while $P$. trivialis prefers subsoil water at only 3 to 4 feet below it. The following table, for the natural preferences of the plants concerned, has been drawn up from data given by Feilberg from observations in Denmark upon sand plains in Skagen.

Water at a depth of 3 inches, Rushes and Moor; at 6 inches, Mosses and Cyperaceae; at 12 inches, normal grass; at I 5 inches Corn does well in dry summers, and at 18 inches to 24 inches in wet seasons. If the water is 30 inches to 40 inches below the surface, the ground is useless for crops, and special dry climate plants appear.

The actual depths apply, of course, only to sandy soil. In clay or other water-retaining ground, the depths will be much greater. In Scotland the relative succession is almost identical. Whenever the ground is allowed to get too damp, mosses (the so-called "fog") make their appearance. This frequently consists of Hylocomium squarrosum, H. triquctrum, species of Hypmum, and other mosses or liverworts, such as Lophocolea bidentata. The wetness of the soil tends to choke the grass roots; and on the moist earth, between 
the grass tufts, spaces are left, which are at once covered by the protonema of these mosses and by liverworts. When the ground becomes a degree more saturated, Rushes, or perhaps Aira cacspitosa, will develop, and marsh-loving weeds, such as the Spearwort, Senecio aquaticus, and Carum verticillatum, will replace Senecio jacobaea, Ramunculus acris, and Heracleum spondylium.

On the other hand, in good soil, where there is no tendency to becoming waterlogged, and especially if the grass is not properly watched, tall herbaceous weeds, such as the Thistles, Ragwort, Cow Parsnip, etc., will soon appear, and almost cover the field. These, as shown in a previous chapter, are preparing the way for the natural forest.

Thus, grasslands are decidedly artificial productions, and this is, of course, also the case with arable lands. The crops grown in this country are all, with one or two exceptions, foreign plants. Of wheat, the original form is unknown. An allied species is found from Achaia to the Caucasus and Mesopotamia. This form Triticum monococcum has been discovered in the Lake Dwellings of the Stone Age in Switzerland; and it has also been discovered at Troy. Cultivated varieties of the ordinary wheat (Triticum sativunn) also occur in the Lake Drellings; and grains of a form closely allied to the ordinary wheat of to-day have been found in Egyptian graves. Oats may have originated from the Wild-oat (Avenc fotuc), which is not uncommon in Britain, or from similar species. This may have been a native of Southern Europe or Western Asia. The original form of the Rye plant (Secale montanum) occurs in Spain, Greece, Armenia, and as far east as Central Asia, and was probably first cultivated in 
Southern Russia and Western Asia. Barley seems to have originated from "Hordeun spontaneum," which is found wild from Asia Minor to Baluchistan, as well as in Arabia Petraea.

Although the existing common rotation of crops is exceedingly modern, only dating from $\mathrm{I} O 0$ to $\mathrm{I} 50$ years back, the common weeds have been able to suit their life-histories to the conditions; and careful examination will show that they vary both at different times of the year and according to the crops. Potato, Turnip, and Cornfields have all their characteristic pests. In the hill-farms, which occupy most of the country in the South of Scotland, the weeds are of a much more humble and inconspicuous kind. Potentilla tormentilla, Galium saxatile, Violets, and Polygala are probably adapted to live amongst the grasses to which their leaves, or leaf segments, bear a close resemblance. Here the tendency is much more towards the formation of a peatmoss, and Sphagnum may often be discorered. On the very porous and thirsty soil of the South Downs, it will be found that the weeds altogether differ from those found in Scotland.

The plants found upon the accumulations of blackband shale, ballast heaps, and railway tracks form an entirely peculiar and distinct series. The conditions of these places are quite different from, for instance, those prevailing on bare arable land, or even on ordinary roadsides, or on the ground near human dwellings. The cinders, gravel, or shale is unworked, virgin material, and has at first but little organic matter, consisting of rotted plant remains. It has no bacterial population; and, in addition, the ground is bare to the sun's rays, and evaporation must be exceedingly vigorous. Even some of the weeds of cultivated ground, 


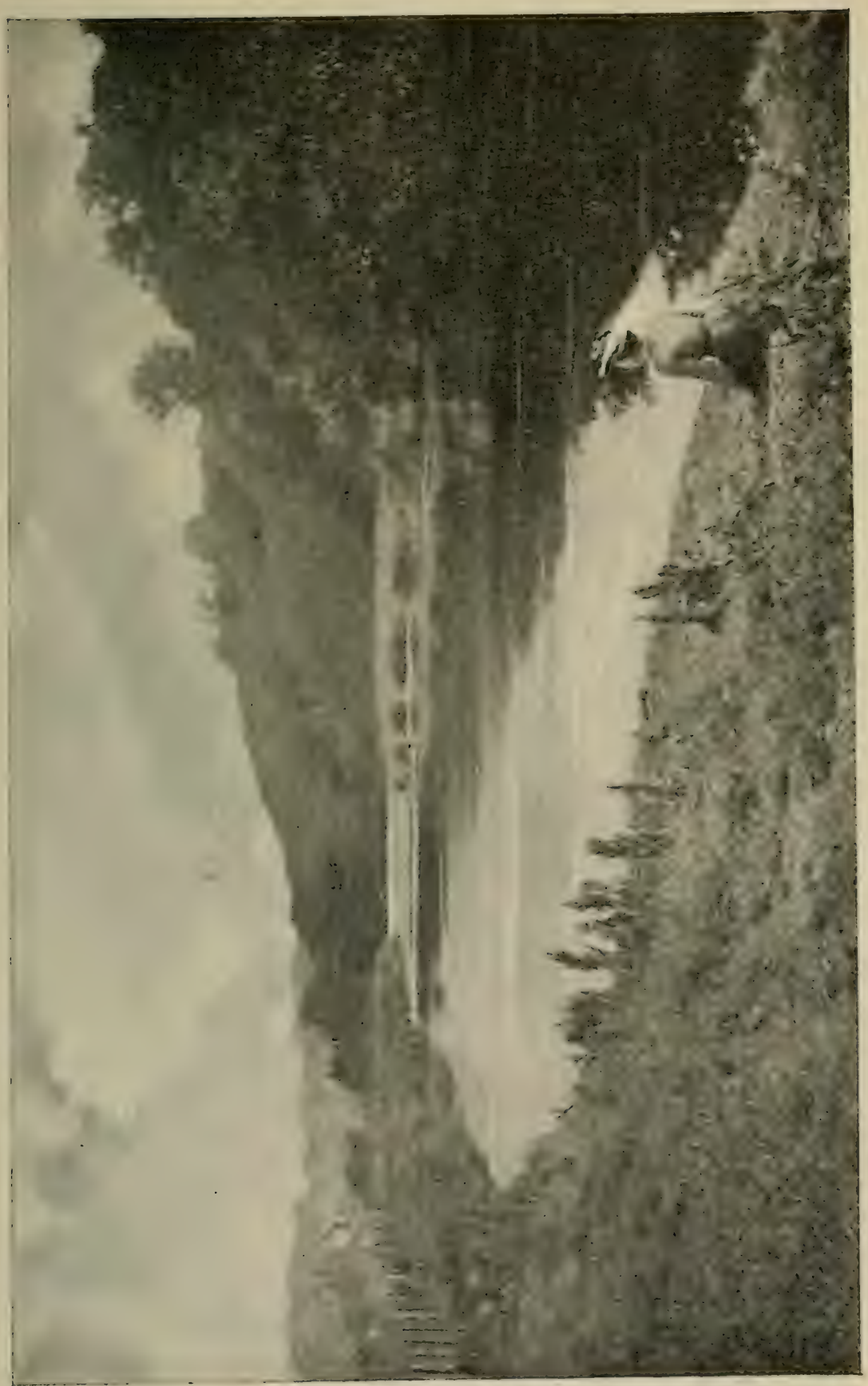

.

$<$ \&

.

三尺

류

点

氺

है.

을

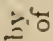

동

跣

¿.

है.

ter

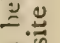

$\therefore$ के

픙

跣

th

능 ธ용

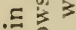

을

ह的

(1)

如

.

을

잉

ฝै है

U.

ㅇํㅇ

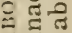

$<$

- है

年

c.

踏

현 cis

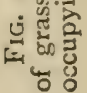


like the Poppy and Cudweeds, are adapted to drier conditions than those prevailing in an ordinary meadow. But the railway-track, and shale-heap flora is of decidedly Southern affinity. Many Mediterranean species are able to live perfectly well upon the cinders and shale of Scotch railway lines, though they never spread into the surrounding country. This artificial ground flora varies greatly in different places. Each shale heap seems to have an individuality of its own, although a gradual occupation by one species after another, is usually quite clearly marked in any one district.

Near Glasgow, the usual succession on the flat top of such a shale heap and on its sides, is often quite different. On the sides scattered specimens of Senecio viscosus appear able to develop almost anywhere, even on the steepest and most weathered slopes. From the base of such a heap masses of Equisetum arvense and the skirmishing runners of the Colt's Foot extend some distance upwards. If they are at all favoured by a depression or miniature ravine, the Colt's Foot may even reach the summit. After these Equisetums and Colt's Foots have affected the shale for some little time, Heracleam spondylium, and a few other coarsegrowing plants make their appearance. Occasionally, but not often, masses of Grasses or of Hieracia may be found on old slopes. Both Hawthorn and Roses are also able to root on the sides of these heaps. On the summit a much more varied flora is able to exist. One of the most characteristic types is a Hieracium, found in extraordinary quantities, and often almost by itself. Between the leaves of this plant the ground is thickly covered by low tufted mosses.

The most remarkable point is the absence of many 
plants very characteristic of waste ground, such as Polygonum Persicaria, Chickweed, Spurrey, and the Nettle. Standing on one of these heaps, one may see on the one side a grass field, in which there are hundreds and thousands of Scnecio jacobaea, Ranunculus acris, Docks, and other weeds; on the other, a field of turnips, in which Polygonum, Spurrey, and Chickweed exist by the hundred thousand; but a close search on the summit will only reveal perhaps three plants of Ragwort, half a dozen Docks, and not one single example from the turnip field.

Yet the explanation is simple. The shale heap is unprepared soil similar to the barren rocks on which the Highland Hieracia develop. The grass and turnip fields are richly prepared by manure, and by the work of generations of crops carried on during many years. On older heaps plants of Heracleum, sometimes with roots five feet deep, and a great variety of other plants are found. Ramunculus repens also often covers the ground with a network of prostrate stems. Grasses after this begin to form a sort of sward, and odd plants of Senecio Jacobcea, Dock, Thistle, Plantago Lanceolata, Mouse-ear Chickweed may eventually develop. Hawthorn and Roses are quite common, though Brambles are decidedly unusual. For some reason the stolons of the Bramble, even when the plant is grown outside, but close to the base of the shale heap, seem unable to send their roots into the shale, and they lie flat on its surface in a limp and unhealthy-looking manner. The comparative poverty of the sides is probably due to the steep angle, which involves the washing away of the organic matters, as soon as they are formed. It might, however, be quite possible to cover both the top and sides of such a heap with a thicket of Roses. 
The Flora of these shale heaps has been given in more detail, because many railway lines are composed of clinkers, or some similar material, and it is not so easy in the case of these embankments to distinguish between the ordinary field weed-flora and that peculiar to the cinder tracks. It will be seen, that not one of the ordinary field weeds takes a leading part on the shale. Persicaria, Spurrey, Chickweed, and Nettle are generally not to be found upon them.

The railway-track flora is, in Scotland, decidedly different from that of the fields through which the railway runs. Generally, as has been already shown, the plants found upon the cinders are, especially at first, of a more Southern affinity. The following are among the most conspicuous: Hieracium aurantiacum, Tragopogon porrifolius, and Linaria minor. Anthyllis vulneraria and Hieracium pilosella are also very characteristic of railway banks in some places, as well as almost all the plants quoted above for shale heaps. Many escapes and plants unusual in the district are to be expected on railway sidings, both from the character of the ground, and also on account of the special facilities for travel, which are afforded to the plants by the railway trucks coming from all parts of the country. Very often, the embankments and the cuttings show quite different floras.

Another very characteristic flora seems to depend for its existence on the waste nitrogeneous soil, to be found near the dwellings of mankind. In the very centre of the African continent one can determine with accuracy the site of a former native village by the presence of nettles. In Britain the common Nettle, Plantago Major, Chickweed, Shepherd's Purse, Docks, Chenopodium, and others, are the characteristic forms. Plantago major, the "White Man's Footsteps" of the Red Indian, owes its 
presence, probably, to the extraordinary power which its leaves possess of resisting pressure from above. "The others are all hardy and quick-growing weeds, which delight in rich soil, and multiply very rapidly. Thus there are at least four groups of "weeds," or artificial

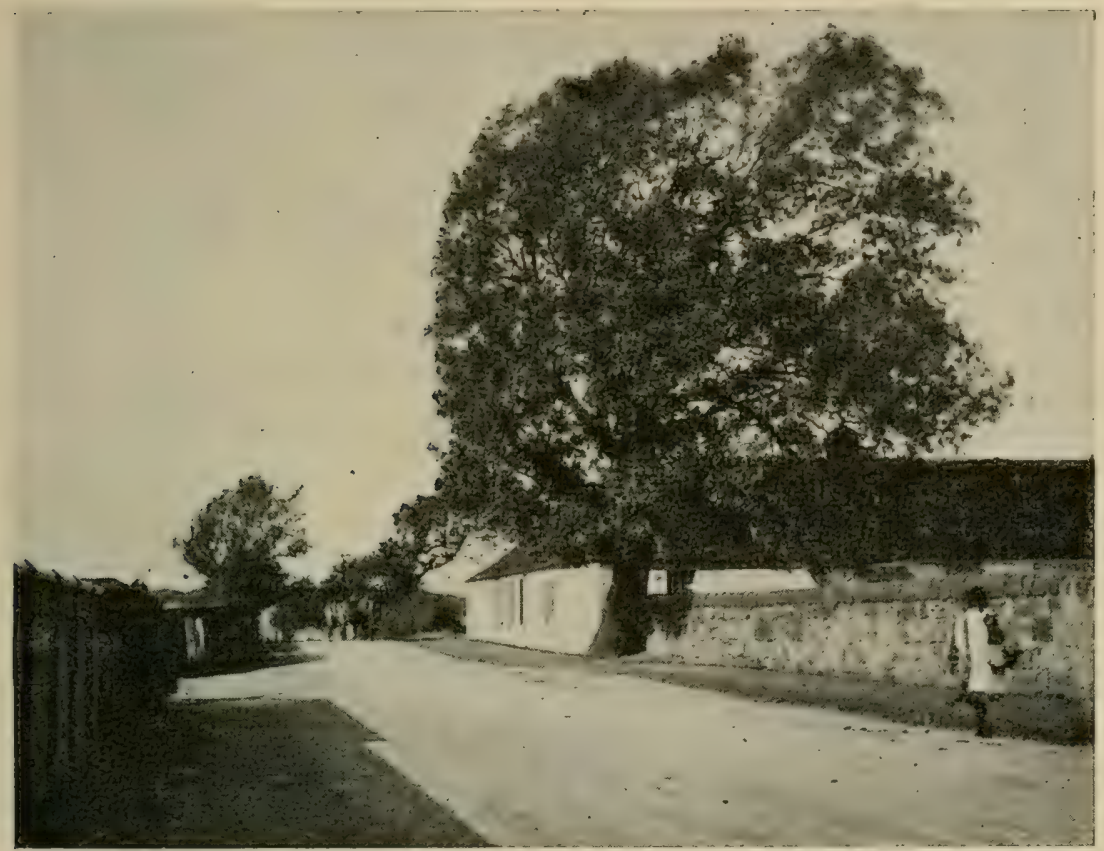

Fig. 43.-Tree Injured by Engine Smoke. The foliage surface is nearly straight on the injured side. Photographed from the railway bridge. The distant trees show injury by wind.

floras, which owe their existence to civilised man. The arable and pasture weeds, those of shale heaps, of railway tracks, and of the rich nitrogeneous waste lands by roads and human dwellings.

These have not, however, the melancholy interest which attaches to the destructive effects of smoke, and to river pollution. The prevalent winds in the West of Scotland are from the south-west, and for two miles or more to the north-east of a factory, the trees, and even 
the mosses and lichens, clearly show the evil effect of the sulphur and coaldust. If trees are in a narrow valley, so that the smoke blows over them, they are often quite uninjured; but upon a slope towards the factory, or in the direction of the usual winds, they are greatly injured. The damage seems to be done chiefly in spring, especially during the few days in which the leaves are unfolding, and the annual shoots are elongating. What exactly causes the damage seems rather uncertain. It is probably the sulphur fumes, or the closing of the lenticels and stomata by coaldust, that destroys the young leaves and twigs. The effect can be clearly seen even in winter time. The usual dome-shape of the twigs of a healthy tree is altered. On the side exposed to smoke the outline of the branches is either a straight line or a concave curve, and the whole growth becomes greatly suppressed in that direction. Later on, the twigs on the injured side die; and eventually the most sheltered ones are affected, and the whole tree becomes attacked by beetles, and decays away. The Rhododendron, Privet, Holly, Plane, Sycamore, and Lime seem best able to withstand coal smoke. Mosses, lichens, and liverworts, on the other hand, appear to be exceedingly susceptible to it.

The water flora also is subject to destruction. If too much nitrogeneous matter enters a stream, the diatoms and fresh-water algae are replaced by a bacterial population. A fungus, Apodya lactea, also often covers the entire bottom of a running stream with a sort of scum or furred growth, i 8 micro-millimetres thick, of a peculiarly horrible appearance (Turnbull). These fungi and bacteria are of course engaged in purifying the water, as is shown by the products given off. There appears to be a regular succession. 
(I) Bacteria with green Flagellatae, Euglena and other animals, and then (2) Diatoms, Oscillatoria and Green

Algae.

Thus, in Britain, it is clear that there are exceedingly few associations of plants which are entirely uninfluenced by man's multifarious activities. The present population consists of a successive series of vegetations which, like geological strata, cover and are often mixed up with one another. There was (I) the original Atlantic flora, in which man's influence was, at first, imperceptible. Then came (2) the Prehistoric Oaks and Pinewoods altered by fires, and by the grazing of neolithic and other cattle. Then followed the (3) Cultivated plants, with their train of weeds; and, finally, a purely artificial flora, which depends upon the miner, the railway engineer, and in a still greater degree upon a certain slackness in artistic and scientific work. Inliers and Outliers are, except in the case of the last, very difficult to find.

Yet this is only an insignificant part of the earth's history. The soil has been formed by the work of Ferns and Clubmosses which have now disappeared from the earth's surface. The roots of flowering plants, microbes, fungi, and animals have been, through ruthless extermination, forced to specialise and develop, until they can co-operate efficiently with one another, and thoroughly exploit the earth. Upon dry land, lichens, mosses and special flowering plants have been trained to occupy, and win for higher plants, bare rock and barren sands. Even the sea and fresh water have been populated with active vegetable labourers; some of which are made to reclaim mudbanks, others to enrich the marine and estuarine mud with valuable organic matter, or to support the fishes, and, in part, mankind. 
The green covering of the earth is nearly continuous. It passes through and under the water and from the snow-line downwards over every undulation of the surface. We may try to distinguish the connections and mechanism of a single plant, or even of a single flower or leaf. The result in either case is the same. We find ourselves at once on the shore of the ocean of human ignorance. Just enough can be distinguished, to show us that there is a meaning in the minutest detail of its behaviour, in its microscopical structure, and in its general organisation and position in the world. So it is also with associations or societies of plants. The members, though always in competition, are nevertheless useful to the society and to one another. The higher type of society overspreads any country, which has been made sufficiently fertile by the preliminary labours of some less efficient association.

Cultivated plants are now, in civilised countries, the dominant forms, and every year they occupy a little more of the earth's surface. Thus the whole series of sunlight-catching foliages is seen to have a definite and intelligible meaning. They are making the earth fit to yield her profitable fruits, in due season, to the one animal which is capable of the reverent study of Nature. 


\section{BOOKS OF REFERENCE AND AUTHORS CITED IN TEXT.}

\section{ABBREVIATIONS.}

THE following important Botanical Journals are continually quoted. Those marled * contain abstracts (in English), and are well worth the attention of all teachers. Those marked + contain abstracts in German, and are essential for research students.

As an example: Annals Botany, Vol. xıI. p. I3, would be cited A.B. I2, p. I3.

A. B. Annals of Botany.

A.J.B. Annales du Jardin Botanique de Buitenzorg.

A.S.N. Annales des Sciences Naturelles Botanique.

B.A.R. British Association Reports. * BI. C. Biologische Centralblatt. $\uparrow$

B.B.C. Beihefte zum Botanischen Centralblatt.

B.C. Botanische Centralblatt. $中$

B.D.B. Berichte d. deut. Botan. Gesellschaft.

B.D.C. Ber, d. deut. Chem. Gesellschaft.

B. U.S. Bulletins of the United States Department of Agriculture.

C.B.B. Centralblatt f. Bakterienk. Abtheilung 2.

C. R. Comptes Rendus (French).

G.J. Geographical Journal.

J.R.H. Journal Royal Horticultural Society. *

J.S.A. Journal Society of Arts.

J. w. B. Jahrbuch. f. wiss. Botan.

N. Nature.

N.S. Natural Science.

N.S.G. Trans. Natural History Society, Glasgow.

o. B.z. Oesterr. Botan. Zeitung.

I.J. Pharmaceutical Journal.*

I'RING.J. Pringsheim's Jahrbuch. f. wiss. Botanik.

P.R.S. Proceedings Royal Society, London.

R.G.B. Revue Generale de Botanique.

S. G.M. Scot. Geographical Magazine.
T.R.M. Transactions Royal Microscopical Society. *

w. F. Wollny, Forsch. auf. d. Gebiet. d. Agrikulturphysik.

Y.U.S. Yearbooks of the United States Department of Agriculture.

General Works : (I) Kerner von Marilaun and Oliver Natural History of Plants, London (Blackie) I897; (2) Lubbock (Lord Avebury) Flowers, Fruits and Leaves, London I883; (3) Lubbock British Wild Flowers, London I8go; (4) Willis Flowering Plants and Ferns, Cambridge I 897.

Chapter I. General Works (5) Muller Fertilization of Plants, London I883; (6a) Kmuth Bluthenbiologie; (6b) Lubbock Ants, Bees and Wasps, I 886. SPRENGEL (7) Willis N.S. 2, I893. CROSSBREEDING (8) Daravin Effects of Cross and Self-Fertilisation, London $18 ; 6$ and (9) Variation of Animals and Plants, I86S. (Io) B.U.S. (many papers) ; Flower Colour (I2) Bonnier R.G. B. 2 (1890) p. 529; (12b) Cirant Allen Colours of Flowers, London I882 ; (13) Ekstams. B.C. 78, p. 5 I ; PETAL-TRANSPIRATION (I4)CurtelA.S.N.6 p. 22 I. Also P. J. May 20 I 899. LinnaEirs Clock (I) Kerner. 
Fossil Insects (I 5) Goss Geolog. Antiquity of Insects.

Insect Mouths (5) Muller 1.c. ScENT (I6) Holmes P.J. March, Sept. I900, Dec. I90I.

SNaIl AND Bat Flowers (4), (17) Ludwig Biologie der Pflanzen, Stuttgart I 895. BIRD Flowers (I8)A.B. Scott Elliot.

Temperature (I), (19) Burgerstein O.B.Z. 5 I p. I85.

PollenpRotection

Lidforss J.W.B. 33. FLOWER Industry (2I) Agric. Journ., Cape of Good Hope 18 p. 487.

Chapter II. General Works (2), (17) ; (22) Hildebrand Verbreitungs. d. Pflanzen, Leipzig I873; (23) Dingler Die Bewegungs. d. Pflanz. Flugorgane, Munich. FrUits (24) Green Manual of Botany, London I895. CotToN (25a) Watts Economic Dictionary Products of India. Awns $\left(25^{b}\right)$ Hackel True Grasses, London I896; Wheat-skating (25c) Dewey Y.U.S. I 896 . FRUIT DISTRIBUTION (26) Ule B.D.B. I8.

Chapter III. General Works (25c) Pistia (27) Ito A.B. 12, p. 466. SUGARCANE (25a) Watts. WALKING FERN (I); (27b) Goebel Organographie d. Pflanzen, Jena 1900; BANYAN (25a) Wits; (28) Lindley Treasury of Botany, London 1889. Mangroves (29) Hemsley Challenger Reports I. I 885 ; (30) Schimper Die Indomalay. Strandflora I 88I ; (3I) Colonial Reports Miscellaneous No. 3, Sierra Leone. Thistles, TumbleweEns, etc. (25c) Derey. Colchicum, Alliums, Plantago $(32,33,34,55)$ Rimbach B.D.B. I4 (1896) p. I64; I 5 ( I 897$)$ pp. 93, 248; I7 (I896) p. 8 and B.C. (I900) p. I8I. RASPBERRY ROOTS (36) N.S.G. 5 (I897-I898). MALEFERN and BOAR (37) Crombie Brown Forests of Eng- land. Manioc (38) Carmody P.J. (I900). HEAT AND POTATOES (39) Wollny w.F. I6 Heft 3,4 .

Helianthus Experiment (40) Vochting B.C. 82 (I900).

Chapter IV. General Works (4I) Lubbock On Seedlings, I892; $(27 b)$ Goebel ; (I) Kemer; (25c) Dervey; (42) Balfour B.A.R. I90I.

Cell (43) Grew Anatomy of Vegetables begun 1672 .

Cell Life (44) BurdonSamnderson P.J. (I900) Sept.

Cell Connections (45) Gardiner P.R.S. 62 (I897), 67 (I900) p. 437. Poisons (46) Bokomy BI.C. I9 p. I77.

Wheat, Cereals $\left(25^{b}\right)$, $(27 b),(47)$ De Candolle Origin of Cultivated Plants. CyclAMEN (I). HaRdNess OF SEEDS (48). Ott O B.Z. (I 900) Heft 7 (49) Scott Ellliot B.A.R. (I9OI).

WeEdS, Avena, B.U.S. and Y.U.S. MIMICRY (2) and (3).

Heat, Cold, etc. (50) Jodin C.R. I 29 p. 893; (5I) Dezuar and Thisclton Dyer P.R.S. 65 (I899); Thespesia (52) Hemsley A. B. (I89I) p. 406 ; MimosA (I) Kerner. OAT, FENNEL, Nelumbium (53) R. Brown N. 55 (I 896$)$ p. 21 . OIL, Mucilage (.54) Hunger B.C. (55) Crookes B.A.R. (I898).

Chapter V. General Works (56) Ormerod Manual of Injurious Insects, London 1881 ; (57) Leaflets published by Secretary Board of Agriculture.

Codlin Moth (58) Slingerland U.S. A. Oregon I899-I900. RoEDEER, RABBiTs, etc. $(58 b)$ Schlich Manual of Forestry, London I896; (59) Maxwell Memories of the Months.

BEES AND SPORES (6o) Woronin Mém. de l'Akad. Imp., St. Petersbourg, Vol. 36, I888. CORK Healing (6r) Lockell B.C. 88 , p. 243. LENTICELS 
(62) Devaux A.S.N. I2 (I900) p. I. LAtex (63) Bell Naturalist in Nicaragua, London I888; (64) Parkin A.B. ( I 900) p. I93; (65) Gaucher A.S. N. I2 (I900) p. 24I ; (66) P.J. January I 900.

Rubber Sufply (67) J.S.A. August 24th 1900. RESIN (68) P.J. July I $3^{\text {th }}$ IgOI. QuiNine FORMATION (69) Lotsy 13.C. 84 (1900). ETHEREAL OILS (46) Bokorny. CRystals (70) Stahl see (17) Ludzig pp. 236-240. SPINES, THORNS (7 I) IJenslow Origin of Plant Structure, London I895; (72) Lothelier C.R. II 2 (I89I) p. III ; (73) Mittmann Pflanzenstacheln, Berlin IS88; (74). Rootspines, Scott A. B. I I (1897). DRy Clinate EFFECT. This is only thoroughly understood by an examination of a good herbarium of Egyptian, South African, or Grecian plants; (75) Volckens Flora d. AggyptArab. Wiiste, Berlin I887.

NetTle $(76 a)$ Lightfoot Flora Scotica; $(76 b)$ Sozverby English Botany. ANT-KEEPING Plants, belt l.c. ; (78) Schumann Ameisenpflanzen, Hamburg 1889; (79) A. F. W. Schimper Pfl. u. Ameisen, Jena 1888.

BRACKEN (I 7 ). MiteHOMES (80)Lundstrom Pflanzen. biolog. Studien, Upsala I887; (8I) Malme 13.C. 83 , I 900 ; (82) Delpino Bull. della Soc. Bot. Italiana. Ott Igor.

Galls (83) Kuster Flora I887. GREeNFLy $(84)$ Buckton British Aphides, I876-83.

WASH FOR GREENFLY (85) Consins Chemistry of the Garden, London I898; Percival, see below. WHEAT SUPPLY (86) Annual Returns of the Board of Trade; $(87)$ Agricultural Returns for Great Britain. Plantlouse-Fungi (89) Macchiati Bull. Soc. Bot. Ital., Firense I90I.
Chapter VI. General (90) Perival Agricultural Botany, London I900; (9I $a$ ) WarmingLehrbuch. d. Okol. Pflanzengeographie, Berlin I896 (I) Kerner.

SoIL (9a $b$ ) Ebermayer Die Physik. Erwirk. d. Waldes, Berlin 1873; (92) Warington Physical Properties of the Soil, Oxford 1900. UGanda, EAst AfricA (93) Scott Elliot Naturalist in Mid Africa, London I895. Physical Characters OF SoIL (94) Schruarz Arb. landw. chem. Versuch, Wien I870. Railivay Plants (95) Dunn Rugby School Reports I898. TREE ROOTS (586). RADISH Rnots (96) Carricre Origine d. Plantes Domestiques, also(97) Varignyand others cited by Henslow (7I). GRowTh, REACTIONS OF RoOT (27b) Goebel; (98) Juel PRING.J. 34 (I9O0) p. 527. FUNGUS-SERVANT (99) Stahl PRING.J. 34 (I900) p. 539. WORMS (I00)

- Darvin Formation of Vegetable Mould, etc., London I88I ; also (9Ia) Warming. ANTS (IOI) Drummond Tropical Africa.

Chapter VII. General Works (2) Lubbock; ( 102 ) Lubbock On Buds and Stipules, London I 899.

Chlorophyll Bodies (103) Haberlandt Physiolog. Planzenanatomie, Leipzig I884. SUNSHINE HouRs (IO4) Bartholomew Physical Atlas.

CARBON-ASSIMILATION (IO5) Green Introduction to Vegetable Physiology, London I900; (106) Tsvett C.R. I 29, p. 607 ; (I07) Brown and Escombe P.R.S. 67 (I900) p. I24; (IO8) Brozun B.A.R. I9OI. Convolvulus TYPE (IO9) N.S.G. (I896-1897). RAINLEAVES (I) Kerner; ( I IO) Hansgirg Sitz. d. Kön. Böhm. Ges. d. Wiss. Prag. Math. Natur. Klasse I900. DRrP TIP (III) Jungner B.C. 47 (189I) p. 354. Glossy Leaves 
(I7), (I I2) Siahl A.J. B. I I (I893) p. 98. LEAFSLEEP (II 3 ) F. Darwin Elements of Botany, I896; (I I4) F. Darvin and Acton Practical Physiology I 894. Anthocyan (I I 5) Overton PRING.J. 33, Heft 2. Chlorophyll (i16) Straslurger Textbook of Botany p. 201, also ( 108 ).

Chapter VIII. General Works (103), (II7) F. Darwin B.A.R. I896, p. IOI4, also (II6) and (24). Chemical Substances (I I8) $M e r$ C.R. II 2, I890, p. 964; ( I I9) Keegan N.s. Sept. I898 and Dec. I 899. TENSIONS IN STems (I) ; ( I 20) D'Arsonval C.R. 133 (1901) p. 84. EXPERIMENTS (I2I) Farmer Elementary Botany, also (I I 3 ) and (I I4). ASCENT OF WATER (122) Dixon and Joly. Proc. Roy. Irish Acad. I 898. TABLE chiefly from Haberlandt (123) Schrvendener Mechanish. Theorie, Leipzig I878; (124) Weinzierl Sitz. Wien. Akad., Vol. 76, 1877; (125) Ambrom PRING.J. I2 (I88I); (I26) Firtsch B.D.B. I 883 and others ; also (127) Grestach O.B.Z. 5I ; (I28) Damm B. B.C. I I, Heft 2.

Chapter IX. General Works (128) Murray Study of Seaweeds, I895, also Warming. PLANKTON (130) Bachmann B.c. 84, p. I58; (131) Schorler B.C. 83, I900; ( I 32) Gravelius Zeit. f. Gewasserkunde; (133) Zacharias Die Tier u. Pflanzenwelt d. "uisswasser, Leipzig I89I. Dratoms (134) Van Heurcke Treatise of the Diatomacere, London I896; (135) Whipple Technolog. Quarterly, Vol. VII. p. 214 ; (136) Voigt BI.C. (190I) p. 30. OIL IN DIATOMS (137) B.1.C. 32 , p. 940. DESMIDS (138) Cooke British Desmids, London I881. HALOSPHAERA (9I $a)$ pp. I 32,145, I 46. Dis. TRIBUTION (I 28), (9I $a$ ). LAND
Formation By Plants (9Ia), (139) Scott Elliot Annals Andersonian Naturalists, Vol. II. p. 67. JURA ( I40) Magnin R.G. R. (I893). WATER-BUTTERCUP Henslow l.c. (I4I) Liiern Proc. Cambridge Philosoph. I872.

Chapter X. General Works (I42) Crookshank Manual of Bacteriology, London I887; (I43) Green Ferments and Fermentation; (144) Jorgensen Microorganisms and Fermentation, London I900; (145) Migula Systeme der Bakterien, Jena I900; (146) Flugge Die Mikro. organismen, Leipzig I896; (I47) Hofman Bacterien und Hefen, Berlin 1899. SoIL Bacteria (I48) Gottheil C.B.B. 7 (I9OI); (149) Berthelot Chimie Agricole and Percivall.c. AIR BACTERIA ( 50$)$ Weinzierl J. Cincinnati Soc. Nat. Hist., Vol. xIX. I900. Flower BACTERIA (I 5I) Freire C. R. 128, p. 1047. London Sewage ( 152 ) Lazes and Jordan Leicester Lit. and Phil. Soc. Trans., Vol. IV.; ( $152 b$ ) Cloues J.S.A. Dec. I 4, I9O0. CreaM Bacteria (I 53) Conn and Eisten C. B.B. 7, 190 I. Bubonic Plague (I 54) N. I899, p. 2I 4. DISEASE FORMS (155) Bulloik N. I898, p. 339. REsistance 'TO HEA'T, etc. (I56) Macfadyen P.R.S. 67. Sunshine (I57) Kedzioz B.C. 83, p. 240. Poisons (I 58 ) P.J. July I4, I900 and Feb. 9, I90I Charabot C.R. I 32, p. I 59; (159) Bokorny Chem. Zeits. I900. CABbage Experiment (I60) Stoklasa P.J. July I4, 1900. Nitrate Formation (I61) Jacobitz C.B.B. 7, 1901. Bacterial Plant Diseases (I62) Oester. Ungar. Zeit. f. Zuckerindustrie rgor, p. 26 ; (163) U.S.A. Dept. Agric. (Veg. Path.) No. 28, I90I. PARASITIC MUCOR (164) Lucet and Constantin Bonnier R.G. B. 
12. Amylomyces (165) Holtz C.B.B. 7 ; $\left(165^{b}\right)$ Silnikoff and Romnel B.C. 85. Moulds (166) Klokker Die Garungs Organismen, Stuttgart I900. PurE Célture Yeast (167) Hansen Practical Studies in Fermentation, London IS96, also (I66) and (144). YEAST EXTRACTS (168) Albert B.D.C. 33, I90I ; (169) Chemik. Centralblatt I90I ; (I70) Lebbin P.J. Sept. I4, 1901 .

Chapter XI. General (17 I) Tuboeuf Diseases of Plants, London I897 ; (I72) Massee Textbook of Plant Diseases, London I899. BAsIdIOMYCETES (I73) Stevenson British Fungi, London 1886 ; (174) Constantin Nouvelle Flore des Champignons, Paris; (175) Cooke Handbook and (176) Illustra. tions to British Fungi, London I87I and I881; (177) Massee British Fungus Flora, London 1893. Conidial Nature of BAsidiospores (I 78 ) Massee Journ. Linnean Soc. I900. Spore Distribution, Massee A. B. IO, p. I32. Similarity of Wholesome and Poisonous Species (I80) Arcangeli B. C. 84 , p. 380 . PhosphoRESCENT FORMS (I8I) McAlpine Proc. Linn. Soc., N. S. Wales, Vol. 25, p. 548. DRY RoT $\begin{array}{lll}\text { (182) MIarpmann } & \text { C.B.B. } 7\end{array}$ (I9OI). AsCOMYCETES (I83) Phillips British Discomycetes, London 1887; (184) Cooke Vegetable Wasps and Plant Worms. CANKER (185) Bra C. R. I 29, p. II8. ERGuT (186) Smith Diseases of Field and Garden Crops, London 1884 . Rust FungI (IS7) Plowrisht Monograph British Uredineae and Ustilagineae, London 1899. SPORE Distribution (i 88 ) Klebrhn Zeits. f. Pflanz. Krank. Band 1900, PRING.J. 34 p. 347. CROPS (I9O) Y.U.S. I897.
Myxomycetes (I9I) Lister Mycetozoa, Lendon 1894.

Chapter XII. General (192) Lint isay Popular History of British Lichens, London 1856 ; (193) Boistel Nouvelle Flore des Lichénes, Paris; (194) Leighton Lichenflora of Great Britain, Shrewsbury I879; (195) Crombie Monograph of British Lichens, London I894. Cell Connections (I96) Saller Reports Meetings Linnean Soc. I90I-1902. ANASTOMOSIS (197) Bitter" PRING.J. 33, Heft I ; (198) Malme B.c. 89 (I9O2). STRUCTURE (I986) Scott Flowerless Plants, London I895. Lichen Cup (199) Darbishire J.w.B. 34, I899.

Chapter XIII. General (200) Hobkirk Synopsis British Mosses, London I884; (2OI) Douin Nouvelle Flore des Mousses, Paris; (202) Dixon Student's Handbook British Mosses, Eastbourne I896. Peat Bogs (203) Miall N. ( I998) p. 377. PEAT (204) Geilie Textbook of Geology, London I885; Warming (bibliography) ; (205) Weber B.C. 88 (I9OI). ANT$\Lambda$ RCTIC (205b) Bernacchi G.J. May I90I, p.478. Antheridia (206) Schaar B.C. 74 (1 898$)$ p. 279. Anatomy (198b); (207) Campbell Mosses and Ferns, London I 895.

Chapter XIV. General Works (208) Heer Primaeval World of Switzerland, London I876 ; (207); (I9Sb); (209) Britten European Ferns, London I88I, also (219) and (220). BRACKEN AND PINe (2Io) $R$. Smilh Botanical Survey Map and Notes (Bartholomew). Scythian LAMB (209). PODURA AND PRothallia (2I I) Lang Paper read at British Association (Bristol Meeting). SPORES OF Selaginella $(27$ ). BACteria Coal Measures (212) 
Renault Bull. d. Musée d'Hist. Nat., Tome 2, p. 285, I896. COAL (2I3) Sexton Fuel, London 1897. Fossil Botany (2I4) Solmes Laubach Fossil Botany, Oxford IS9I; (215) Servar Fossil Plants, Cambridge 1898 , also VESUVIAN Lavas (2I6) Comes Le Lave, il Terreno Vesuviana e la loro vegetazione 1887 . KRAKATOA (2I7) Treub A.J.B. 7 (I 888) p. 213. FOSSIL INSECTS (15) and (218) Scudder Bil) iography Fossil Insects, Washington I 890. Recent History Plants (219) Reid Origins of the British Flora, London 1899; (220) Engler Humboldt Centenaarschrift, Berlin (Kuhl) I899.

ChAPTER XV. General Works( 1986 ); (219), (2206) Geikie Prehistoric Europe. Transpiration(22I) Hohnel W.F. 4. PINE CONE (22Ib) Worsdell A.B. (I900). Distribution (222) Dinde Hand. d. Pflanzengeographie IS90. BRITISH FlORA (220), (223) Watson Geograph. Dist. Brit. Plants, London I843; (224) Niven S.G.M. Jan. I902. Alpixe Plants (225) Limaens Flora Alpina I756; (7I); I 2). Silt of Torrents (226) Penck Morph. d. Erdoberflache, Vol. I., Stuttgart I894, p. 304 .

Chapter XVI. General Works Warming, Ebermayer (227) R. Smith N.S. 14, I899; (228) S.G. M. July-August I 900 ; (229) I Smith S.G.M. March 1902. For foreign countries many papers are to be found in (230)
Engler Botanische Jahrbucher. AbSORPTION-Light (23I) Stahl and Wiesner PRING.J. 34 (I900) p. 615. Soll, Evaporation see L:bermayer, Schlich, Warington. InCREASE OF TREeS (232) Renuick and Makay Itandbook British Association (Glasgow Meeting) I90I. TIMBER SUPPLY (233) Hutchins J.S.A. Nov. 24, 1899; (234) Schlich J.S.A. March I, I90I.

Chapter XVII. General Works. Warming. PALAEOLITHIC MAN (235) Quatreforges Human Species, London I881. EFFECT OF Fires (236) Schaffner Botanical Gazette, Vol. xxvir. I899. KANUTE'S FORESTS (237) J. Crombie Brown British Forests. Neolithic MaN (238) Lubbock Prehistoric Times and (239) Origins of Civilisation, London 1878 and 1882 ; (240) Keane Man Past and Present; (241) Sergi Mlediterranean Race, London I9OI.

Formation of Towns, etc. (242) Chisholm G.J. Jan., Nov. I897 ; (243) Mill G. J. ( (900) p. 205 , 353. STATISTICAL Accounts (243) Old I79I, Nerw I830-I 845. FeilberG $\left(243^{b}\right)$ see Warming l.c. (9I $a$ ) p. 48. POA l.c., p. 321 . Origin OF Cultivated Plants Hackel and (245) De Candolle Origin of Cultivated Plants, I886. Fog EFFECTS (246) Oliver J.R. H. I6 (1894) p. I, also Schlich. Polluted WATER (247) Tumbull Trans. Bot. Soc., Edin. 62 (1898). 


\section{INDEX}

\section{With Explanation of some Terms.}

Absorption system of woods, 308. [ [ 442. Acacia, 108, I10, II3, Acer, 98, 319 .

Achenes, dry non-splitting fruits, one free carpel, one seed, 44 .

Achillea, 28, 330.

Acids, 97, 10.

Aconite, I3, 82, 105.

Acuminate, drawn out at tip, $\mathbf{J} 38, \mathbf{1} 44$.

Aecidiomycetes, 230.

Aegopodium, 69, I50.

Aeration, I18, I23, I86, 309, 315. [312.

Agaricus, 21I, 227, 310,

Age of trees, 169 .

Agriculture, 327, 328.

Agrimony, 43, 53 .

Alchemilla, 289, 298.

Alder, I55, I65, 286.

Alectoria, 244, 245 .

Aleurone, small rounded proteid grains, 75 .

Algae, II7, I48, 339 .

Alkaloids, 97, I04.

Allium, 60, 65, 172 .

Alpine plants, 296, 298, $300,302$.

Amaryllidaceae, I05.

Ambronn, I73.

Amides, substances with $\mathrm{C}$., $\mathrm{H}$., O. and N., I3I.

Ammophila, I92.

Anemone, 45, (7, 75 .

Angelica, 48, 3 I2.

Annual rings, I63.

Antheridia, the organs containing the spermatozoids, 255,276 .

Anthocyanin, I49, I52, I 55, I 66 .

Anthyllis, 118, 337.

Ants, 30, 54, 97, 1ro, II2, I27.

Aphides, III, 213.

Apothecium, the cup of some fungi, 24I.
Apple, 35, 4r, 6r, 92.

Araceae, Arum, I6, 67, I06, I49, Iє6.

Araucaria, I69, 285, 294, 295.

Archegonium, 255, 276.

Arctic plants, 264, 296, 298, 300.

Aril, supplementary seed coat, 50, 52, 53 .

Armeria, 47, 53, I95.

Ascent of water, I66.

Asci, elongated fungus spore cells, 2 I2, 224.

Ascomycetes, 2I2, 2I9, 228,3 IO.

Ascospores, the spores inside the asci,

Asparagin, an amide found in the asparagus, etc., 77 .

Asplenium, 6r, 270.

Astragalus, I07, IC9.

Auricles, basal expansions, leaf, I43.

Autumn colours, I55.

Avena, 50, 53, 83, 332.

Bacteria, I28, 200, 250, 233, 309, 339.

Banana, 24, 4I, 90.

Barberry, $14,26,108$.

Bark flora, 306.

Bartholomew, 299.

Basidiomycetes, 227.

Bidens, I3, 44, 53.

Bees, I2, I3, I4, I5, 20.

Beech, 3I8, 32I, 323 .

Beetles, 93, 100, 309.

Begonia, 58, 62.

Belt, roo.

Bernacchi, 264.

Bignonia, $\mathbf{r}_{3}, 48,53$.

Birch, I20, I55, I65, I74, 266, 3I2, 3I5.

Bird's-nest fungus, 228 .

Bishopsweed, 69, I50.

Blackman, 99.

Bladderwort, 57, 268.

Bluebells, 26, 3 12.

Bock, 49.
Boletus, 222, 223.

Bonnier, 302.

Bracken, 52, 63, III, I $47,270,272$.

Bracts, modified leaves below flower, $78,8 \mathrm{x}$, 82 (Bracteoles, 9, 87).

Bramible, I8, 29, 62, I08, 312, 3I4.

Branching, I69.

Bromus, 69, 307.

Broom, 49, 53, 3I 4, 3I5.

Brown, R., 54, I57.

Buckthorn, 3I, 80.

Bud protection, 26, 27, 87,93, I 48, 27I, 289.

Bulb, bulbil, 6o, 67, 87 .

Bullock, 209.

Bulrush, 46, 53. [I 43 .

Burdock, 29, 43, 53,

Burrs, 42, 43, 44, 53 .

Buttercup, I4, 27, 28, $29,33$.

Butterflies, I5, I9.

Calcite, a mineral, 78 .

Calcium, 249.

Calyptra (the hood covering the capsule of some mosses), 257 .

Cambium (thickening ring of young cells), 92, I 59, I60, I6I, I7 I.

Campion, I3, I4, 30, I3I, $147,307,3$ I 2 .

Cancer, canker, 230.

Capillitium (the threadlike bodies found in some fungi), 228, 234 .

Capitulum (the head of flowers in Compositae),

Capsules (a dry fruit which opens to let the seed escape), 77.

Capsules, moss, 256 .

Carbohydrate, 75 .

Carbon assimilation, I3I, I4I, I56, I57.

Carex, 53, 80, 172 . 
Carlina, 28, I07.

Carpels (female flowerleaves), 53.

Carrot, 27, 53, 69.

Castor oil, 80, 83, 84 .

Catapult fruits, 50 .

Caterpillars, 93.

Cattle, $323,324,326$.

Cell, cellulose (cellwall substance), $7 \mathrm{I}$, $72,73,74 . \quad$ [II3.

Centaurea, 18, 29, 107,

Cerastium, I6, 300.

Ceterach, 270, 287.

Chenopodium, 54, 88, I69, I96, 336, 337 .

Chestnut, 84, 297, 318.

Chickweed, I6, I44, $335,336,337$.

Chloroplasts, protoplasmic bodies carrying chlorophyll, $\mathbf{r}_{3} \mathrm{r}$.

Chlorophyll, leaf green.

Cilia (small hairs of protoplasm), I84.

Citrus, citron, 37, II3.

Cladonia, 193, 240, 244, $245,246,250$.

Cleistocarp, 2I2.

Climbing modifications, I5I.

Clinging fruits, 4I, 42.

Clover, I3, I54.

Clubmosses, 277, 287.

Coal, 28I.

Cochlearia, Scurvygrass, I93, I94, 195.

Cockchafer, 94.

Codlin-moth, 94. [315.

Cold, 26, 27, 84, 201 ,

Collenchyma (special strengthening tissue), I64, I73.

Colonisation, Ch. III.

Colour of flowers, I3, I6, 20, 2I, 33, 300 .

Colour of fruits, 35,39 .

Colour of fungi, 220, 22I, 222.

Colour of lichens, 248 .

Colour of twigs, $39, \mathrm{I} 69$.

Coltsfoot, I43, I 5 I, I52, 230, 335 .

Compositae, $15,22,23$, $28,29,45,53,77$.

Conidia (non-sexual spores), 2 ro.

Conifers, 169, 294, 289.
Conjugation (union of two cells not distinctly male and female), I79. [138.

Convolvulus, I8, 27 ,

Cork, 89, 96, I57, I59.

Corm, fleshy swollen bases of stem, 8I.

Cortex (part of stem between epidermis and central cylinder), I22, I 59, Ió3.

Cotton, 46, 80, I73.

Cotyledon (seed-leaf), 37, 7I, I86, I87.

Cow parsnip, I4, 49, I 42, 337.

Crocus, 27, 28, 64.

Crookes, Sir Wm., 90.

Crossbreeding, crosspollination, II, 25 .

Crow, 54.

Cruciferae, 22, 84, I05.

Cup and trumpet lichens, 244.

Cuttings, 59.

Cycads, $165,285$.

Cyclamen, 28, 77.

Cynoglossum, 43, 53.

Cyperaceae, sedges, 45, I97, 33I.

Cystocarp (see Red algae), 242.

Daisy, 28, 29, I32, I42, I 52,33 .

Damm, I73. [I7I.

Dandelion, 30, 65, I66,

Dante, ${ }^{3} 3$.

Darbishire, 242.

Darwin, 45, 127.

Date, 76, 86, I7 I.

Deadnettle, $x 6,26,172$.

Defence, 67, 72, 92 .

Desmids, 178.

Diatoms, I76, 252, 339 .

Dichasial cyme (inflorescences which divide in pairs of branches), 23.

Dickson, 255, 299.

Dicotyledon (with two seed-leaves), I7I, 286.

Dingler, 46, 49.

Dioecious (plants with male and female flowers on different individuals), 280.

Discomycetes, 219.
Dock, x5o, 333, 335 , 336.

Dog's Mercury, I7, I8, $66,87,150,307$.

Douglas. Fir, I20, I50, I69, 29I, 293.

Drosera, 266, 268.

Dryas, 45, 53 .

Dryness, 68, Io6.

Economy of material, 30,32 .

Ectocarpus, ז8I, I96.

Ekstam, 2I.

Elastic and explosive distribution, 49, 53 .

Elm, I35, I44, I65, 3 I7.

Elodea, 58, I9o.

Endocarp (carpel-lining), 78 .

Endodermis (innermost cells of cortex), I22, I59, I60.

Endosmosis, diffusion into cells, 242 .

Engineering mechanism, 30, I 47, I7I, I74.

Enteromorpha, I80, I8I, I82, I9I.

Enzymes (ferments secreted by the protoplasm), 2 r2.

Epidermis, the outer skin, 97, 98, I73.

Epilobium, I8, 46, 53.

Equisetaceae, I85, I88, $278,283,287,335$.

Erosion, 3I7.

Escapes, 337.

Eucalyptus, Io6, I68.

Euphorbia, 54, 100.

Evernia, 243, 306.

Fats, 77,164 .

Feilberg, 330.

Fern, fern-allies, 179.

Festuca, I09, I92.

Fibres, I62, I72.

Finger and toe, disease of turnips, etc., 236 .

Fires, 321, 324, 326.

Firtzsch, I74.

Flag, 27, 185 .

Flax, 32 .

Fleshy fruits, $35,36,4 \mathbf{I}$.

Flies, I4, I5, 18, I9.

Florida hyacinth, 57, I75, I79, 254 .

Flower, 9-34, 53.

Fluoride, a mineral, 78 . 
Foodstores, 7 I.

Foliage, Ch. VII.

Fontinalis, 253, 263 .

Forests, Ix4, 320, $32 \mathrm{I}$.

Forget-me-not, 22, 27 , 43.

Fossils, Ch. XIV.

Foxglove, 13, 22, 28, 29, I05, I 5I, 307, 3I2.

Frost, I 5t, 201.

Fruit (the flower after fertilization), 35 .

Fruit-jellies, 38, 39, 40 .

Fucus, I80, I82, I9I.

Funaria, 256, 258.

Fungi, 88, 95, 96, 125. I $53,309,312$.

Gardiner, 72.

Garlic, 60, 65, 68, 307.

Garton, Messrs., I2.

Gastromycetes, 218, 227.

Geikie, 297.

Gentian, I8, 32, I44.

Geological history of plants, 283 .

Geranium, 49, 58, I46.

Germination, 7 I, 84, 85 .

Geum, 44, 53.

Glossy leaves, I48.

Goat, 94, 323, 324.

Goebel, 255.

Gooseberry, 232, 305 .

Graphidei, 249.

Grasses, 12, 27, 86, I45.

Grasslands, 329, 332.

Greenflies, 93, 98, х 12.

Greitach, I73.

Grew, 7I.

Gueldres Rose, 40, 305.

Gum, 103, I07, I 50, I 52.

Gyrophora, 245, 248.

Haberlandt, I73, I74.

Hail, 99.

Hairs, 38, 4I, 45, 53 , $57, \mathrm{X} 49, \mathrm{I} 5 \mathrm{I}$.

Hansen, 213.

Harshberger, 54 .

I Iarvey, I82.

Hawthorn, 35, 39, Io8, I52, 305, 312, 314, $317,335,336$.

Hazel, 54, 78, 8x, 323 .

Heat, 84 , I 54, 20 I.

Heather, I4, 26, I92, 266,324 .

Heer, 283 .

Henslow, I7o.
Heracleum, 53, I42, 3 I 3,33 I, 335,336 .

Herb Robert, 34, 49.

Hieracium, 65, 335 .

Hippocrepis, 83 .

Hobkirk, 259.

Holly, 35, IO9, 339.

Honckenya, I20, I92.

Honey, I2, I3, 33.

Honeysuckle, 8, 16, 305.

Hooks, fruits with, 4I, 53.

Hop, 48, 53.

Hordeum, 69, 332.

Horsechestnut, 84, I35. I39, I46, I53, I58, I69, 317.

Horseflies, I4, I5, 3 I.

Horsetail, I87, 278.

Humblebee, I2, I7, 3I.

Hunger, Dr., 88.

Hutchins, Mr., 3I9.

Hyacinth, $17,26,65$, I73, 307, 3Ir.

Hygroscopy, 50, 53 .

Hylocomium, 193, 307, $33 \mathrm{I}$.

$[220,227$.

Hymenomycetes, 2I8,

Hyphae, fungus threads, 2II, 239, 257.

Hypnum, I93, 253 , 260, 26r, 307, 33r.

Indusium, 276 .

Inflorescence (shoot of which buds become flowers), 22, 23.

Inoculation, 207.

Insects and flowers, I3-20; and fungi, 22I, 23I, 235 ; and lichens, 246, 247 ; as enemies, 26, 29, $30,32,37,38,127$, I48, I53, 272, 275 , 309.

Insects, fossil, I8, I9.

Insect mouths, I9, 20.

Internode, stem between leaf bases, I94. Iris, $27,62,67,185$, I88. Ivy, I 5I, I63, 305 .

Kerner, I8, 137, 263.

Koch, 2I3. $\quad[53,105$.

Labiatae, 23, 23, 50,

Laminaria, 173,182 .

Larch, I68, 289, 292.

Larkspur, I3, 3I.
Latex, roo.

Lavaflows, flora of, 283 .

Layering, 59.

Leaf, 99, 272.

Lecanora, 56, 248, 249 .

Lecidea, 248, 249, 250.

Leguminosae, I3, 49, II9, I46, 304, 3I4.

Lemna, 53, 56, 189 .

Lemon, 37, 179, 254.

Lenticels (airpores on stem)

Lepidodendron, 278 , 285.

Lichens, I48, 238, 339 .

Light, I37, I38, I54.

Lightfoot, Dr., 223.

Ligule (scale found on grass leaf), I45.

Liliaceae, Lilium, 28, $47,48,65$, I05, I73.

Lime, 48, 53, I20, I35. I $36,144,147,339$.

Linaria, 37,77 , I17.

Linnaeus, I8, 3ог.

Lister, 213, 236.

Liverwort, I79, I93, $262,339$.

Lochsides, I84, I85.

Lubbock, 50, 87, I35, I 36, I 45, I $_{53}$.

Ludwig, 45 .

Lupine, I33, I53.

Lychnis, $16,30,32$.

Lycopodiaceae, Lycopodium, 278, 279, 285 .

Malefern, 62, 67, 27I, $287,307$.

Mammoth trees, 295.

Man, 55,67, Ch. XVIII.

Maple, 49, 53, 76, 86, $286,306$.

Marshplants, $x 84, \mathrm{I} 85$.

Mechanical support, I47, I7I, I72, I74.

Medicago, 42, 53 .

Mediterranean plants, 299, 334 .

Medullary rays, I59, I62.

Melica, 46, 53, 307.

Menyanthes, I88, 295.

Mercurialis, 66, I5o.

Mice, 94, I27.

Mildews, 95, 233.

Milton, 274.

Mimicry, 83, 223, 224 .

Mites, III. 
Monocotyledons (with one seed-leaf), I7I, 286.

Mosses, 250, 306, 309.

Moths, I5, I6.

Moulds, Ch. X.

Mucilage (gunmy varieties of cellulose), 88, 239 .

Mucor, 210.

Mudplants, I93.

Murray, I82.

Mushrooms, 222, 225.

Mycelium (the absorbing part of fungi), 217,225 .

Mycorhiza (fungus servant), 126, 237, 309.

Myosotis, Forget-menot, 15,53 .

Myrmecophilous (plants which keep ant guards), IIo.

Myxomycetes, 234, 3то.

$M^{3}$ Call, I57.

MacKay, 3I7.

Narthecium, 42, 46.

Nectria, 229, 310.

Nettle, 26, I35, I44, $150,312,336,337$.

Nitrogen, I28, 20I, 202, 203, 204.

Nivell, 267.

Nucleo-proteid (proteids with phosphorus), 213.

Nucleus, 74 .

Oak, 25, 54, Iо3, I20, I $55,267,286$.

Oats, 22, 27, 54, 55, 84, $86,297,298, \quad 318$, $322,323,324,327$, 332 .

Oils, $36,38,77,164$.

Olive, $35,39,279$.

Operculum (the capsule-lid of mosses), 257.

Orange, $33,35,36,37$, $4 \mathrm{I}, 72,8 \mathrm{O}, \mathrm{I}_{4} 2$.

Orchids, 27, 49, 68, $75,268$.

Ormerod, II2.

Oscillatoria, $189,339$.

Osmosis (diffusion into or out of cells), IIg, I23.
Ott, 78.

Overton, I49.

Ovate (egg-shaped), I32.

Ovules (female sporangia, which become the seed), Io.

Palms, 76, 108, I65, I7I.

Panicle, 23.

Pansy, I2, 2I.

Papyrus, II4, I73.

Paraphyses (barren cells amongst the asci), 242.

Parasites (attacking live plants or animals), 220, 237.

Parmelia, 240, 247, $248,250,306$.

Pasteur, 209, 213.

Paterson, I5I.

Peat, II8, 263, 264, $265,266,288,3$ I 5 .

Pedicel (flower stalk), 50, 69.

Peduncle (stalk of inflorescence), 50, 69 .

Peltigera, 239, 240, 24I, 248, 306.

Penicillium, 96, 210, 2II, 2I2, 218.

Percival, 232.

Pericycle (outermost cells of central cylinder), 98, I22, I23, I59, I60, I63.

Peridineae, I76, I77.

Peristome (the teeth forming the inside covering of the moss capsule), 257, 258 .

Peronospora, 2II, 232.

Pertusaria, 249, 306.

Petals, inner flower leaves, Io, 53 .

Phloem (food materials are carried by phloem tissue), I22, I59, I60, I62. [224.

Phosphorescence, I77,

Photosynthesis, I31.

Phragmites, 42, I86, I88, 323 .

Phycomycetes, 232.

Physcia, 247, 248, 306.

Phytophora, 88, 218, 233.
Pine, 24, 47, 53, 78, 80 , IOI, I6I, I68, I93, $267,286,324$. Pith, I59.

Plankton (floating life of sea, lakes, rivers, etc.), I75, I77, I80.

Plantain, 65, 139, 194, I95, 330, 336, 337 .

Plasmodiophora, Plasmopara, 95, 236.

Plasmodium, 236, зто.

Pleurococcus, I82, 183 , 25I, 307.

Plowright, 232.

Plum, 4I, 8I, 323.

Plumule (shootbud of seed), $7 \mathrm{I}$.

Poa, 89, I90, 330.

Podetia (the little stalks of some lichens), 244.

Poisons, 82, 104, 202, 222, 223.

Pollen (male spore), Io, 24, 26, 3I ; resistance, 28, 29.

Polygonum, 30I, 335.

Polyporus, 227, 310.

Polytrichum, I73, 258, $262,263,307$. [80.

Pomegranate, 38, 4I,

Poplar, I46, 286. [334.

Poppy, I7, 28, 3I,

Potamogeton, 54, r85, I90.

Potato, 29, 59, 62, 67, 90, II9; disease, 233 .

Potentilla, 63, I37, I92, I93, 332.

Prickles, 97, Io6.

Proteid (consists of carbon, hydrogen, oxygen, nitrogen, sulphur), 75 .

Prothallium (product of germination of fernspores), 276 .

Protonema (the green threads produced by moss-spores), 256.

Protoplasm (the living matter of animals and plants), 7I, 74 .

Prunus, 8I, I44, $3^{1} \mathrm{~T}$, 323. [23I.

Puecinia, 2rr, 230, Puffball, 219, 228. 
Pyrenomycetes, 2r9, 229.

Pyrus, I45, 3I7, 323.

Quercus, IO4, III, 3I8.

Rabbits, 94, 222. [7I.

Radicle (root of seed),

Ragwort, 24, I42, 33I, 335.

[334.

Railway flora, I7 I, 33I,

Rain, 26, 27, I43, I45.

Ranunculus, $17,64,66$, 67,88, I05, I22, I49, I85, I90, 33I, 335 .

Raphides (needle-like crystals of calcium oxalate), Io6.

Raspberry, 66, 305, $3 \mathrm{I2}, 323$.

Rats, 94, I27. [242.

Red Algae, I8o, I84,

Reeds, 42, I85, I86, I96, 264, 323 .

Reid, 295.

Renwick, 317.

Resins, 97, IOI, I4I, I67, 289, 290, 293.

Respiration, 84.

Rhacomitrium, $257,262,263$.

Rhizines (the absorbing threadwork of lichens), 239.

Rhizoids (the absorbing hairs of mosses, etc.), $257,259$.

Rhizomes (underground root-like stems), 62, 63, 64, $66,67,69$.

Rhizomorphs

(the strings due to matting together of fungal threads), 226.

Rhododendron, 94 , I35, I 54, 339.

Richardia, I06, I49.

Rimbach, 65 .

Rock flora, I9r, 250.

Roedeer, 94, 222.

Root, 65, 66, 69, I25.

Root pressure, I67.

Rosaceae, Rose, I8, $28,33,35,39,62$, I08, I46, I92, 305 , $314,333,335,336$.

Rotation of crops, IIg.

Rowan, 39, I45, I65, $305,312,315,317$.
Rubber, I0o.

Ruppia, I94, I95.

Rush, I72, I85, 264, 33 . [230.

Rust and smut fungi,

Rye, I74, 332.

Saccharomyces, 213.

Sagina, 25I, 259.

Sagopalm, 90, I65.

Salix, 302, 315 .

Salt, I94, I95.

Salter, 240.

Sandflora, I20, I92.

Saprophytes (living on dead or decayed matter), 220, 237 .

Sarcina, I98, 200, 207.

Sargasso-weed, I75, I79.

$[87,133$.

Saxifraga, 29, 60, 6r,

Scent, I6, 21, 33, 37, 97, 105.

Schimper, 255.

Schizomycetes, I99.

Schlich, 3 I8.

Schwarz, II7,

Schwendener, $x 73, x 74$.

Scirpus, I72, 196, I97.

Scott, 185.

Scudder, I9.

Scurvygrass - association, I93.

Seagrass, 25, т93.

Seaveed, Ch. IX.

Seaside plants, I9I.

Secale, Rye, I73, 332.

Sedges, 45, I72.

Seed, seedcoat, seedling (the ovule after fertilization becomes a seed), 37, 53, 7 I.

Seed distribution, Ch. II., III., 54, 55 .

Selaginella, 277 .

Senecio, I42, 3I4, 33I, $334,335,336$.

Sensitiveness of plants, 26, 120 .

Sepals (outermost flower leaves), 9, 29, 53.

Setaria, 44, 53. [206. Sewage - purification, Shale heap flora, 334 .

Sheep, 94, 51, 323, 324. Shepherd's Purse, 54.

Shingle flora, 192.

Sieve tubes, I62.
Silene, I8, 298.

Silverweed, 63 , I37.

Sleep of leaves, I54.

Slime fungi, 225.

Sloane, 54 .

Sloe, I08, 165, 314, $315,323$.

Slug, 22, 222, 224.

Snake, 337, 338.

Snails, 22, I06.

Soil, II4, II 5, II7, I28, 202,340 .

Soil bacteria, 202.

Solanaceae, 39, I05, I54.

Soredia (the grey dust on lichens), 242.

Sparmannia, I64, I67.

Spermatozoid, male spore, 255, 276.

Spergula, spurrey, 28, $335,336$.

Sphagnum, 253, 255, $264,265$.

Spines, 97, Ioo.

Spirogyra, I82, 190.

Spores (reproductive cells),

Sprengel, 9.

Spruce, 120, I68, 169.

Squirrel, 222.

Stachys, I05, I50, 307, 3I2.

Stamens (male flowerleaves), Io.

Starch, 75, 76, I 56, I 57.

Stem, 62, Ch. VIII.

Stevenson, 223.

Stigma (the end of the carpel which receives the pollen), Io.

Stinging hairs, 97, IIO.

Stipa, 5o, 5I, 52 .

Stipules (expansions at base of leaf), I 42, I 53.

Stomata (air-pores on leaf), 99, I 40.

Stone flora, I8I, 250, 257.

Strasburger, 156.

Strawberry, 4I, 62, 63,65 .

Strength of wood, I73.

Style (narrow thin end of carpel), IO.

Suckers, 62, 63 .

Sugar, 38, 39, 40 . 
Sugarcane, $59,63,76$, 165.

Sundew, 266, 268.

Sun flower, I35, I68.

Sunlight, 26, 2r.

Sunshine, I3I, I56, I57, 20I.

Sycamore, 47, II2, I65, I67, 339.

Sympodial, 63.

Syrphidae, I4, I5.

Sweet Gale, 266, 286, 3 I4.

Siveet Pea, I2.

Sweet Vernal Grass, 25, 105 .

Tanacetum, 68, 146.

Tannin, Tanning, 7 , ro3, 205.

Taxus, 80, 3І8.

'Temperature, 3I5.

Tensions (of stem), 166.

'Testa (seed-coat formed from ovule coats), 37,75 .

Thorns, 97, 106.

Thistles, 18, 63, 312, 330, 33r.

Thyme, 29, I05.

Tracheids (sap-carrying cells), 122, 16I, $29 \mathrm{r}$.

Tragopogon, 80, II7, 336.

Transpiration, ascent of water, 167, 290.

Traveller's Joy, 4.5 .

Trichogyne (hair-like cells which retain the male spores), 242 .

Tripolium, 45, 64.
Tuber (the fleshy underground stem of potato, etc.), 64, 69.

Tuboeuf, g6.

Tulip, 18, 22, 23, 27.

Umbelliferae, I4, 22, 23,33 , I05, I46, 330.

Undergrowth in woods, 304, 305.

Usnea, I73, 243, 245 , 306.

Utricularia, 57, 269.

Vallisneria, 26.

Vaucheria, I80, I8I, I96.

Veronica, I5, I8, 3r, 44, 54, I5 I, I9O.

Vessels, I6r.

Vetch, Vicia, 29, 80, III, I93.

Viburnum, 40, I5I.

Violet, Viola, 27, 33, 80,88 , II 7, I93, 332 .

Vine, 95, 96, 167, 297.

Voles, 94.

Volvox, I79.

Walking fern, $61,62$.

Walnut, 8I, 98, 3I7.

Water, distribution of plants by, $53,56,57$, I86.

Water, pollination by, 25.

Water-flora, Ch. IX.

Water-lily, 28, 33, 52, $53,137,185$, I90.

Water-plants, characters of, I86.

Water, soil and, II4, II5.

Wasp, I4, 36, 275.
Warming, 304.

Weather protection, 26, 27.

Weeds, 3I2.

Weinzierl, I73, I98.

Wheat, $45,69,75,80$, $90,322,332$.

Whin, 9, 16, 49, 108, I93, 314.

Willow, 25, 46, 53, 58, I65, 286, 314, 333.

Willowherb, 46, 89 .

Wilson, Dr. J., 12.

Wind, I 45, 337.

Wind distribution by, $45,47,53,56,69$, 293, 294 .

Wind, pollination by, $22,24,25,292$.

Winterbuds, 60, I9r.

Wollny, II6.

Wood, I72, I73, I74, 29r, 3 I 8.

Woods, $320,32 \mathrm{I}$.

Wood floor, 307, 3II.

Woodruff, I34, 307, 3I2.

Woodscrrel, 50, 53 , I 50, I 54 .

Worms, 126, 312.

Worsdell, 293.

Woundwort, I3, 66, I05, I 50, I72, 3 I I.

Yeast, 73 .

Yew, 4I, I69, 318, 327.

Yorkshire fog, 42, 89 .

Xylem (sap-carrying tissue or wood), I22, I59, I60, I6r.

Zostera, 35, 194, I95. 


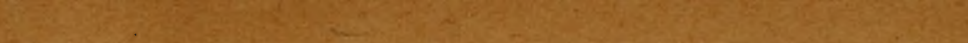

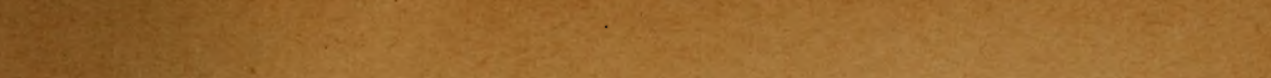

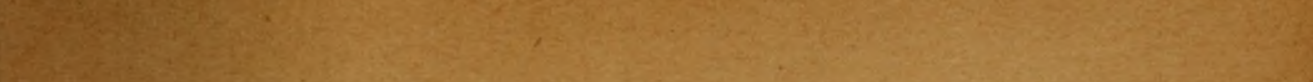

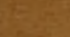

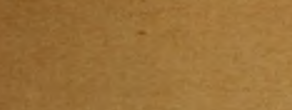

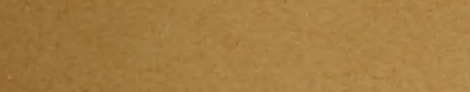

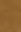
20.0.

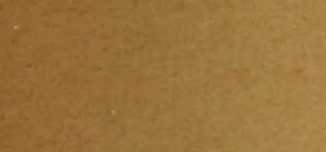
(x)

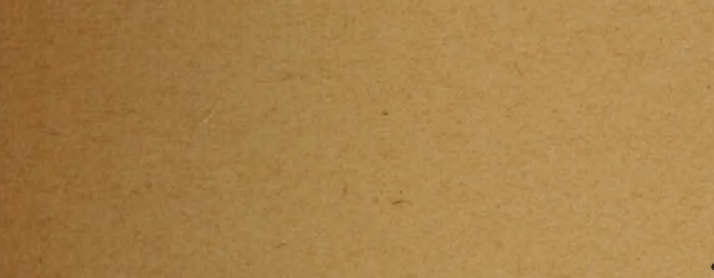
(2)

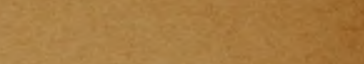

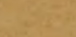

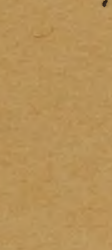

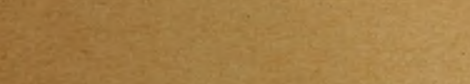
$\frac{2}{2}$

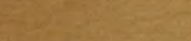
$\cdot \sqrt{2}+x_{2}$ ices

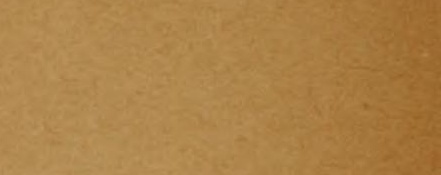

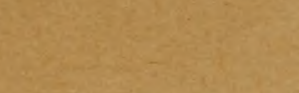





\section{QK47.E4}

Elliot, George Fran/Nature studies (plan

|| || || || || || ||| || || ||| || || || || || || || ||

||||||||||||||||||||||||||||||||||||||||||||||||||||||||||||

35185001054608 
